\title{
5. SITE 445, DAITO RIDGE, DEEP SEA DRILLING PROJECT LEG 58
}

\author{
The Shipboard Scientific Party ${ }^{1}$
}

\section{HOLE 445}

Date occupied: January 11, 1978

Date departed: January 17, 1978

Time on hole: 6 days

Position (latitude; longitude): $25^{\circ} 31.36^{\prime} \mathrm{N} ; 133^{\circ} 12.49^{\prime} \mathrm{E}$

Water depth (sea level; corrected m, echo sounding): 3377

Water depth (rig floor; corrected $\mathrm{m}$, echo sounding): 3387

Bottom felt (m, drill pipe): 3382

Penetration (m): 892.0

Number of cores: 94

Total length of cored section (m): 892.0

Total core recovered $(\mathrm{m}): 619.52$

Core recovery (\%): 69

Oldest Sediment Cored:

Depth sub-bottom (m): 892.0

Nature: conglomeratic sandstone

Age: early middle Eocene

Measured velocity $(\mathrm{km} / \mathrm{s}): 3.6$

Basement:

Depth sub-bottom $(\mathrm{m})$ : not reached

Principal Results: Site 445 is in a small basin in the Daito Ridge, northwest Philippine Sea. Sediments range in age from middle Eocene to Pleistocene, and the cored interval is 892 meters thick. A hiatus in sedimentation occurred during early Oligocene. Occurrence of Nummulites boninensis is limited to resedimented debris-flow conglomerate beds. The carbonate sediments, mudstones, sandstones, and con-

${ }^{1}$ George deVries Klein (Co-Chief Scientist), Department of Geology, University of Illinois, Urbana, Illinois; Kazuo Kobayashi (CoChief Scientist), Ocean Research Institute, University of Tokyo; Stan M. White, Deep Sea Drilling Project, Scripps Institution of Oceanography, La Jolla, California; Hervé Chamley, Laboratoire de Géologie Marine, Centre d'Océanographie, Centre Universitaire de Luminy, Marseille, France (now at Université de Lille I, Villaneuve d'Ascq, France); Doris Curtis, Bellaire Research Center, Shell Development Company, Houston, Texas; Atsuyuki Mizuno, Geological Survey of Japan, Kawasaki, Japan; Henry Dick, Department of Geology and Geophysics, Woods Hole Oceanographic Institution, Woods Hole, Massachusetts; Gennady V. Nisterenko, Vernadsky Institute of Geochemistry and Analytical Chemistry, USSR Academy of Sciences, Moscow, USSR; Nicholas G. Marsh, Department of Geological Sciences, University of Birmingham, Birmingham, England; Douglas Waples, Chemistry and Geochemistry Department, Colorado School of Mines, Golden, Colorado; Dorothy Jung Echols, Department of Earth and Planetary Sciences, Washington University, St. Louis, Missouri; Hisatake Okada, Department of Geology, Faculty of Science, Yamagata University, Yamagata, Japan; Jon R. Sloan, Department of Geology, University of California, Davis, California; David M. Fountain, Department of Geology, University of Montana, Missoula, Montana; and Hajimu Kinoshita, Department of Earth Sciences, Faculty of Science, Chiba University, Tokyo, Japan. glomerates are dominantly resedimented by slumping, debris flows, and turbidity currents. Shipboard analysis of paleomagnetic inclination of samples indicates that Site 445 migrated from an equatorial latitude to its present position over the last 50 m.y.

\section{BACKGROUND AND OBJECTIVES}

\section{Background}

The marginal basins of the western Pacific owe their origin to a variety of processes, and deep drilling during Leg 58 focused on three sites in the Shikoku Basin to test several models for the spreading origin of that basin. Previous Leg 58 results (Sites 442, 443, and 444) indicated that three modes of spreading were possible in the Shikoku Basin: symmetrical spreading, single-limb spreading, and asymmetrical spreading.

The second part of Leg 58 deals with the triangular northwest portion of the north Philippine Sea immediately around the remnant arcs of the Daito Ridge and Basin province. This region has been of considerable interest to several workers, and prior study included deep drilling in the adjoining Kyushu-Palau Ridge at Site 296 (Karig, Ingle, et al., 1975), structural analysis of the basin (Karig, 1975; Hilde et al., 1977; Watts et al., 1977; Mizuno et al., 1975, 1979), and dredging (Mizuno et al., 1975, 1979; Shiki et al., 1976). Magnetic lineations were identified south of the Daito Ridge and Basin area (Louden, 1976; Watts et al., 1977), but none have been identified in the area itself. From this, it has been inferred that the Daito Ridge and Basin region is very old, and that in fact this portion of the northwest Philippine Sea incorporates older crust trapped behind the remnant arc of the Daito Ridge and Oki-Daito Ridge (Karig, 1975; Hilde et al., 1977; Watts et al., 1977; Mizuno et al., 1975, 1979). The trapping mechanism should show similarities with the hypothetical origin of the Bering Sea (Cooper et al., 1976).

Dredge hauls from the Daito Ridge and Basin region, the Oki-Daito Ridge (immediately south), and the Amami Plateau (immediately to the north) indicate that the geology of the region is extremely variable. Greenschist, hornblende schist, and serpentine have been collected from the Daito Ridge, indicating some regional metamorphism (Mizuno et al., 1975; Shiki et al., 1976). Igneous rocks recovered from the Daito Ridge include andesite and diorite of island-arc origin. Dredge hauls from the Oki-Daito Ridge recovered basalt; andesite, granodiorite, and basalt were recovered from the Amami Plateau.

Perhaps the most interesting discovery from dredging is limestone samples containing Nummulites boninensis, 
a larger foraminifer of shallow-water origin. These Eocene samples (Konda et al., 1977) were obtained from these ridges and the Amami Plateau from water depths ranging from 1160 to 2340 meters. This fossil suggests either that the entire area was uplifted during Eocene time and subsequently subsided (Mizuno et al., 1975, 1979), or that the fossils were resedimented from coastal areas into deeper environments. If uplift had occurred, followed by subsequent subsidence, then the Daito Ridge and Basin area represents a remnant arc whose uplift was tied to deep-seated igneous and metamorphic activity or to trench tectonics early in its history (Mizuno et al., 1975).

Site 445 was located in a small sediment pond on the southern side of the Daito Ridge, along a seismic profile surveyed by the R/V Kaiyo-Maru (IPOD-Japan, 1977), shown in Figure 1. The seismic-reflection profile obtained by the D/V Glomar Challenger is shown in Figure 2 .

\section{Objectives}

The primary objectives for drilling at Site 445 were fivefold. Of prime importance was to determine the age of the oldest sediment and of the basement to determine in turn whether this portion of the northern Philippine Sea incorporates old crust trapped behind a remnant arc. A second objective was to determine the nature of the basement and to elucidate its crustal history. A third objective at this site was to determine by sedimentology and paleoecology the nature of the subsidence history of the northwest Philippine Sea. Fourth, climatic changes at the site, presumably due to its supposed northward drift, were to be determined by paleontology and paleomagnetism.

The location of Site 445 near the Kuroshio Current provides a unique opportunity to understand its circulation history. That history can be elucidated from sedimentology and paleontology of samples from Site 445; this was the fifth major objective.

\section{OPERATIONS}

Drilling operations at Site 444 terminated on 9 January 1978. At 0300 hours seismic gear was streamed, and at 0400 hours the Challenger was under way to Site 445 on a course of $236^{\circ}$.

Weather and sea conditions deteriorated late in the evening of 9 January and through the early hours of 10 January. Accordingly, at 1130 hours, 10 January, winds up to $40 \mathrm{mph}$ and extremely high seas necessitated slowing the ship's speed to $140 \mathrm{rpm}$ in order to better ride out the storm. Seismic gear was also retrieved. Storm conditions prevailed until 0400 hours, 11 January, when the ship's speed was increased to $190 \mathrm{rpm}$ and seismic gear was streamed. The Challenger headed for Site 445 on a course of $202^{\circ}$.

At 1600 hours, 11 January, a $16-\mathrm{kHz}$ beacon was dropped, marking Site 445 (Figure 3). Water depth at the site was later established as 3382 meters by drill-pipe measurement. The seismic gear was retrieved; at 1714 hours the Challenger established an auto-mode positioning over the beacon, and RIH was started. Spud-in for Hole 445 was at 0217 hours, 12 January. Core 1, 8.5 meters of nannofossil ooze, was recovered at 0304 hours, 12 January.

A program of continuous coring was followed, the time interval (on deck) between cores being about one hour (Table 1). The sediment nature was consistent and permitted exceptionally high core recoveries (in some cases exceeding 100 per cent; Table 1).

On 16 January, weather predictions showed that a frontal system with accompanying high winds and seas was headed for the site area. Conditions were moderate through the 16th and into early hours of 17 January. However, at 0830 hours, conditions affecting positioning were severe enough to force abandonment of Hole 445. Accordingly, $\mathrm{POOH}$ began, and at 1530 hours, the Challenger was under way to Site 446 on a course of $206^{\circ}$ (Figure 3).

In all, 94 cores were taken, with a total sub-bottom penetration of 892 meters. The length recovered was 619.52 meters, or 69 per cent (Table 1).

\section{SEDIMENT LITHOLOGY}

A single-bit hole was drilled at Site 445 by continuous coring. It penetrated a total of 892 meters of sediments of middle-Eocene to Quaternary age and recovered 94 cores, 619.52 meters in total length.

Sediments are dominantly redeposited biogenic components for the late Eocene to the Quaternary, and dominantly redeposited terrigenous components for the middle Eocene. Five lithologic units were distinguished, based on the biogenic components (units I-IV) and terrigenous components (unit V). Some of the units are divided into sub-units on the basis of dominant color (unit I), abundance of siliceous biogenic components (unit II), and abundance of calcareous biogenic components and sediment texture (unit V). These units and sub-units are conformable, except for an early-Oligocene or lateEocene hiatus between units II and III, discerned from micropaleontological data. Figure 4 shows the stratigraphy at Site 445, and Figure 5 shows the vertical distribution of some lithologic components.

\section{Unit I}

Unit I is predominantly soft to firm nannofossil ooze and foraminifer-nannofossil ooze, with some associated nannofossil-foraminifer ooze, volcanic ash layers, and scattered volcanic ash. Sediments are variously colored, predominantly from gray to brown. Vertical distribution of the dominant colors allows further subdivision into two sub-units.

\section{Sub-Unit Ia}

This sub-unit consists largely of soft to firm nannofossil ooze and interbedded foraminifer-nannofossil ooze, which are locally clayey or vitric and are associated with nannofossil-foraminifer ooze. Dominant colors of these sediments are light gray and pale brown.

The upper interval consists of interbedded nannofossil ooze and foraminifer-nannofossil ooze, whereas the remaining interval is predominantly nannofossil ooze 


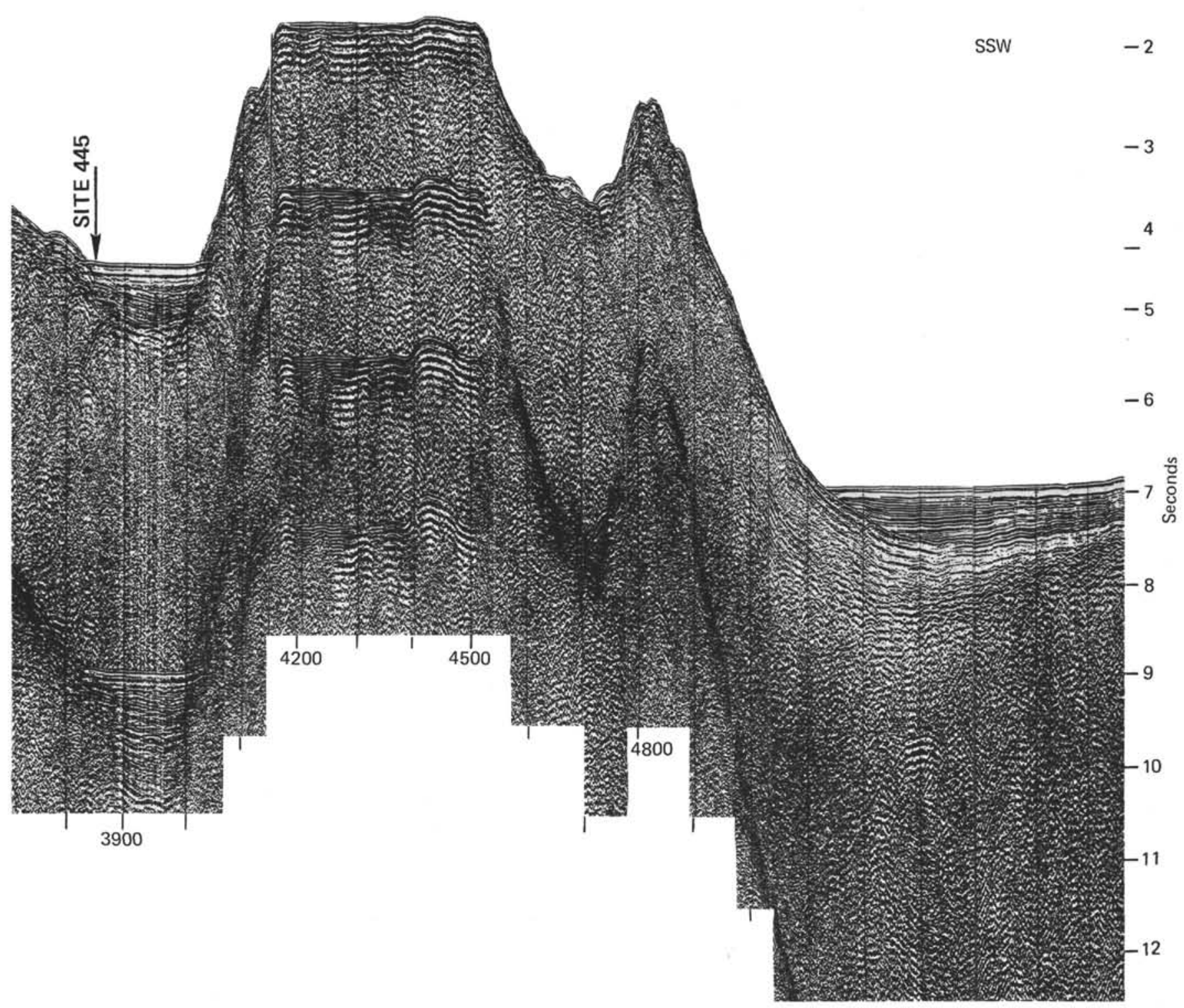

Figure 1. Seismic-reflection profile through Daito Ridge by $R / V$ Kaiyo-Maru.

with subordinate amounts of foraminifer-nannofossil ooze. The sediments are mostly of silty clay texture (nannofossil ooze) to sandy mud texture (foraminifernannofossil ooze). A graded sequence identifiable to the partial Bouma sequence $\mathrm{T}(\mathrm{d}, \mathrm{e})$ is observed in Core 3-3.

\section{Sub-Unit Ib}

This sub-unit is distinguished from sub-unit Ia by sediment color; it consists dominantly of firm, lightgray to white nannofossil ooze, associated with interbeds of foraminifer-nannofossil ooze of various thicknesses.

Foraminifer-nannofossil ooze is dominant in the upper part (Core 10). Nannofossil ooze locally passes to darker-colored, clayey nannofossil ooze which contains clay ( $15-20 \%$ of total).

Coarse-tail graded bedding 5 to $10 \mathrm{~cm}$ thick is commonly found in color-band alternations in the middle part of the sub-unit. It starts from very fine sand- to silt- sized nannofossil-foraminifer ooze or foraminifer ooze with parallel laminae just above a sharp contact, which fines upward to silty-clay-sized nannofossil ooze. It may be identified to the partial Bouma sequence $T(d, e)$. In general, bioturbation is slight to moderate in the middle to lower part. Medium- to coarse-grained calcareous sand occurs only at the lowest part of this sub-unit. Containing about 60 per cent rock fragments, it rests just above the scoured bottom (the lowest boundary of sub-unit Ib) with a 10-cm-thick graded bed and passes upward to nannofossil ooze. This represents another type of graded sequence, equivalent to $\mathrm{T}(\mathrm{a}, \mathrm{b}, \mathrm{e})$.

\section{Unit II}

Unit II sediments are stiffer than those of Unit I. The dominant lithology is a gray, brown, or pink, very firm nannofossil chalk, with varying amounts of siliceous, clayey, and volcanic components. Mudstone occurs locally. It tends to be concentrated at the middle part of 


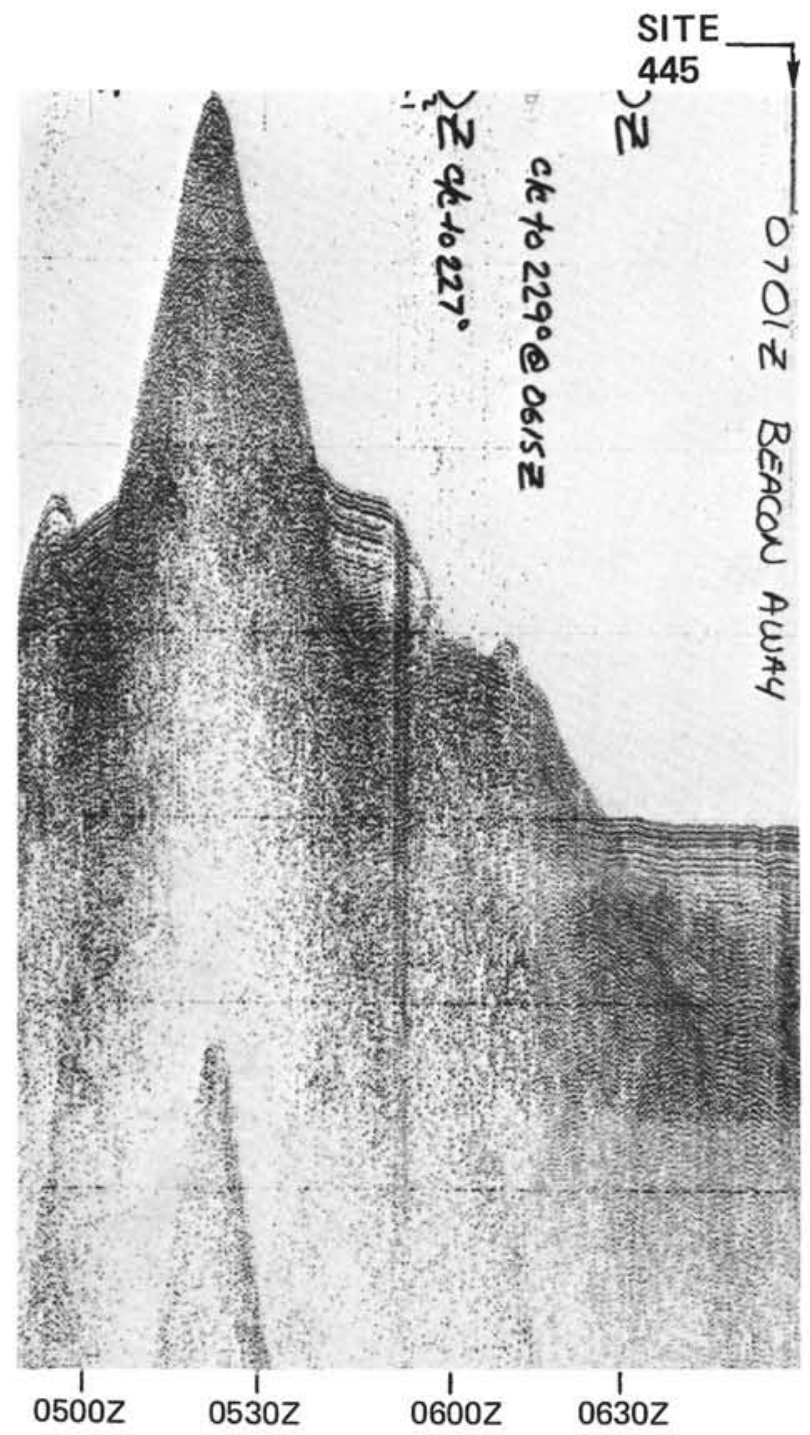

Figure 2. Glomar Challenger seismic-reflection profile approaching Site 445. See Figure 3 for location.

this unit (sub-unit IIb and the upper part of sub-unit IIc). Bioturbation is very common and intense. Calcareous nannofossils occur abundantly throughout the unit. The abundance of siliceous fossils, mostly radiolarians and sponge spicules, varies, and this makes it possible to subdivide the thick sequence of unit II into four subunits. In sub-units IIa and IIc, siliceous fossils are nearly absent, whereas in sub-units IIb and IId they range from several per cent to around 10 per cent or more.

A distinctive aspect of unit II is the extensive occurrence of various sedimentary structures, such as graded sequences and bioturbation, locally associated with slump structures and microfaults.

The graded sequences are coarse-tail and mostly consist of resedimented calcareous biogenic components accompanied by accessory amounts of terrigenous coarsegrained materials at the basal interval, and in some cases by a thin layer of pelagic clay in the upper interval. They include the typical Bouma sequence $\mathrm{T}(\mathrm{a}-\mathrm{e})$ and partial Bouma sequences $\mathrm{T}(\mathrm{c}-\mathrm{e}), \mathrm{T}(\mathrm{d}, \mathrm{e})$.

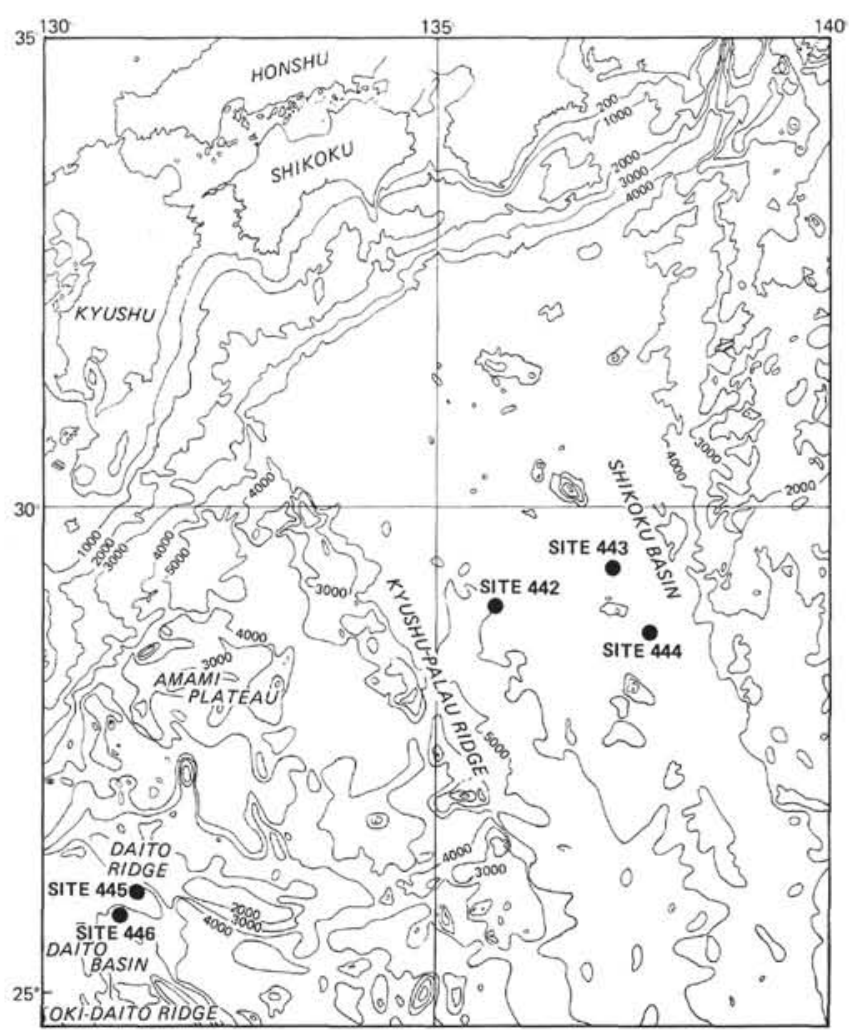

Figure 3. Site location map.

Occurrence of $T(a-e)$ is restricted to the upper part of sub-unit IIa and the lower part of sub-unit IIc, and it mostly overlies, with sharp, scoured contact, the underlying sediments, which are associated with slump structures. It is usually 35 to $60 \mathrm{~cm}$ thick, with rare cases more than 5 meters thick.

Interval a consists of foraminifer chalk or calcareous chalk with lithic fragments and reworked fossils; it is coarse- to very coarse-sand size at the base and mediumto fine-sand texture at the top. In some cases it is partially replaced by calcareous sand with detrital grains of several tens per cent. This interval gradually passes upward to interval b, parallel laminated nannofossilforaminifer chalk of fine-grained-sand size. This passes upward to interval c, foraminifer-nannofossil chalk (very fine-grained-sand to muddy-sand texture) with micro-cross-laminae and (or) convolute lamination. Above this, interval $\mathrm{d}$ is parallel laminated foraminifer-nannofossil chalk (sandy-mud to silty-clay texture). Interval $\mathrm{e}$ is a thick, faintly laminated or non-laminated nannofossil chalk and (or) clayey nannofossil chalk (silty-clay to clay size) with a clay content of clayey materials from a trace to 15 per cent of the total. This interval tends to be slightly bioturbated in the lower part, and moderately to intensely bioturbated in the upper part. Clayey nannofossil chalk is in some cases replaced by nannofossil mudstone.

$\mathrm{T}(\mathrm{d}, \mathrm{e})$ is very common throughout unit II. The thickness of each bed is usually several tens of centimeters, but often decreases to around $20 \mathrm{~cm}$ or increases to more than 4 meters. 
TABLE 1

Site $\mathbf{4 4 5}$ Coring Summary

\begin{tabular}{|c|c|c|}
\hline Cores & $\begin{array}{l}\text { Date } \\
\text { (Jan., } \\
\text { 1978) }\end{array}$ & Time \\
\hline $445-1$ & 12 & 0304 \\
\hline 2 & 12 & 0408 \\
\hline 3 & 12 & 0505 \\
\hline 4 & 12 & 0610 \\
\hline 5 & 12 & 0706 \\
\hline 6 & 12 & 0805 \\
\hline 7 & 12 & 0906 \\
\hline 8 & 12 & 1000 \\
\hline 9 & 12 & 1057 \\
\hline 10 & 12 & 1155 \\
\hline 11 & 12 & 1309 \\
\hline 12 & 12 & 1412 \\
\hline 13 & 12 & 1513 \\
\hline 14 & 12 & 1615 \\
\hline 15 & 12 & 1717 \\
\hline 16 & 12 & 1817 \\
\hline 17 & 12 & 1922 \\
\hline 18 & 12 & 2020 \\
\hline 19 & 12 & 2120 \\
\hline 20 & 12 & 2230 \\
\hline 21 & 12 & 2335 \\
\hline 22 & 13 & 0047 \\
\hline 23 & 13 & 0147 \\
\hline 24 & 13 & 0247 \\
\hline 25 & 13 & 0349 \\
\hline 26 & 13 & 0446 \\
\hline 27 & 13 & 0546 \\
\hline 28 & 13 & 0644 \\
\hline 29 & 13 & 0815 \\
\hline 30 & 13 & 0915 \\
\hline 31 & 13 & 1021 \\
\hline 32 & 13 & 1116 \\
\hline 33 & 13 & 1220 \\
\hline 34 & 13 & 1318 \\
\hline 35 & 13 & 1420 \\
\hline 36 & 13 & 1521 \\
\hline 37 & 13 & 1620 \\
\hline 38 & 13 & 1735 \\
\hline 39 & 13 & 1838 \\
\hline 40 & 13 & 1953 \\
\hline 41 & 13 & 2059 \\
\hline 42 & 13 & 2215 \\
\hline 43 & 13 & 2330 \\
\hline 44 & 14 & 0048 \\
\hline 45 & 14 & 0154 \\
\hline 46 & 14 & 0305 \\
\hline 47 & 14 & 0415 \\
\hline 48 & 14 & 0529 \\
\hline 49 & 14 & 0646 \\
\hline 50 & 14 & 0802 \\
\hline 51 & 14 & 0920 \\
\hline 52 & 14 & 1117 \\
\hline 53 & 14 & 1240 \\
\hline 54 & 14 & 1358 \\
\hline 55 & 14 & 1522 \\
\hline 56 & 14 & 1643 \\
\hline 57 & 14 & 1816 \\
\hline 58 & 14 & 2013 \\
\hline 59 & 14 & 2127 \\
\hline 60 & 14 & 2238 \\
\hline 61 & 14 & 2347 \\
\hline 62 & 15 & 0059 \\
\hline 63 & 15 & 0206 \\
\hline 64 & 15 & 0314 \\
\hline 65 & 15 & 0432 \\
\hline 66 & 15 & 0541 \\
\hline 67 & 15 & 0826 \\
\hline 68 & 15 & 1046 \\
\hline 69 & 15 & 1242 \\
\hline 70 & 15 & 1417 \\
\hline 71 & 15 & 1547 \\
\hline 72 & 15 & 20 \\
\hline 73 & 15 & 1846 \\
\hline 74 & 15 & 2021 \\
\hline 75 & 15 & 2159 \\
\hline 76 & & 2333 \\
\hline 77 & 16 & 0121 \\
\hline 78 & 16 & $03+1$ \\
\hline 79 & 16 & 0446 \\
\hline 80 & 16 & 0606 \\
\hline 81 & 16 & 0730 \\
\hline & & \\
\hline 83 & 16 & 1029 \\
\hline 84 & 16 & 1206 \\
\hline 85 & 16 & 1348 \\
\hline & & \\
\hline 87 & 16 & 1643 \\
\hline 88 & 16 & \\
\hline 89 & 16 & 2018 \\
\hline 90 & 16 & 2153 \\
\hline 91 & 17 & or \\
\hline & & \\
\hline 93 & 17 & 0608 \\
\hline 94 & 17 & 0807 \\
\hline & & \\
\hline
\end{tabular}

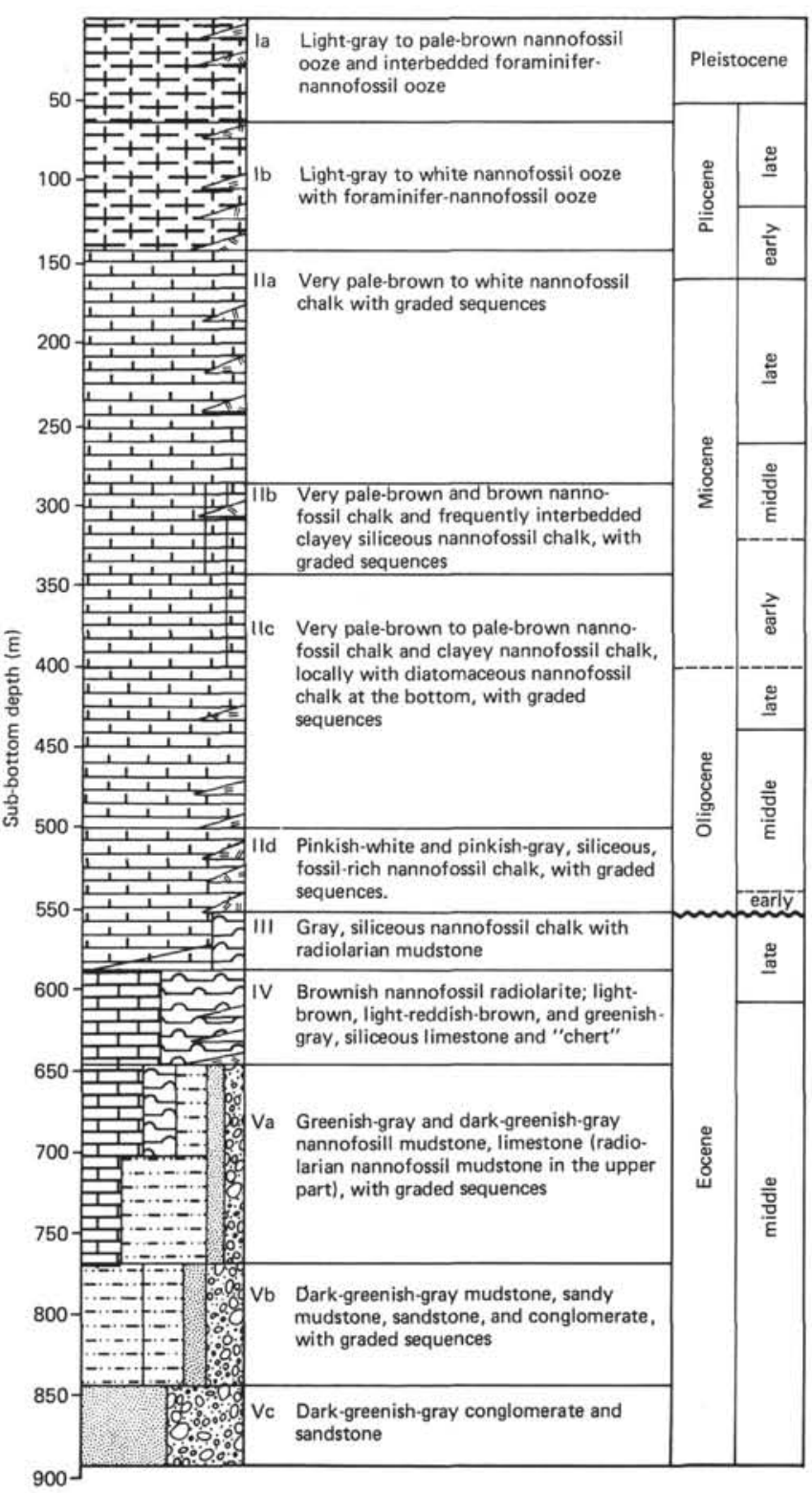

Figure 4. Stratigraphic summary, Site 445.

$T(c-e)$ and $T(a, b, e)$ are very scarce. The former is found in the lowest part of sub-unit IIb, sub-unit IIc, and sub-unit IId, and the latter is restricted to sub-unit IIa and sub-unit IIb.

$\mathrm{T}(\mathrm{b}-\mathrm{e})$ is only observed in sub-unit IId.

Through all the types of sequences, the intervals a, b, and $c$ generally include tests of shallow-water benthic foraminifers, and the $\mathrm{a}$ in the $\mathrm{T}(\mathrm{a}-\mathrm{e})$ sequence contains many lithic fragments of very coarse-grained-sand to granule size, including clasts of muddy sediments formed earlier.

Slump structures occur in some intervals of unit II. They are concentrated in the middle to upper part of sub-unit IIa and in the upper and lower parts of sub-unit IIc. They are represented by slump folds extending vertically through an interval of 2 to 4 meters in most cases, and also by slump blocks of smaller magnitude. Some of them are accompanied by the typical Bouma 


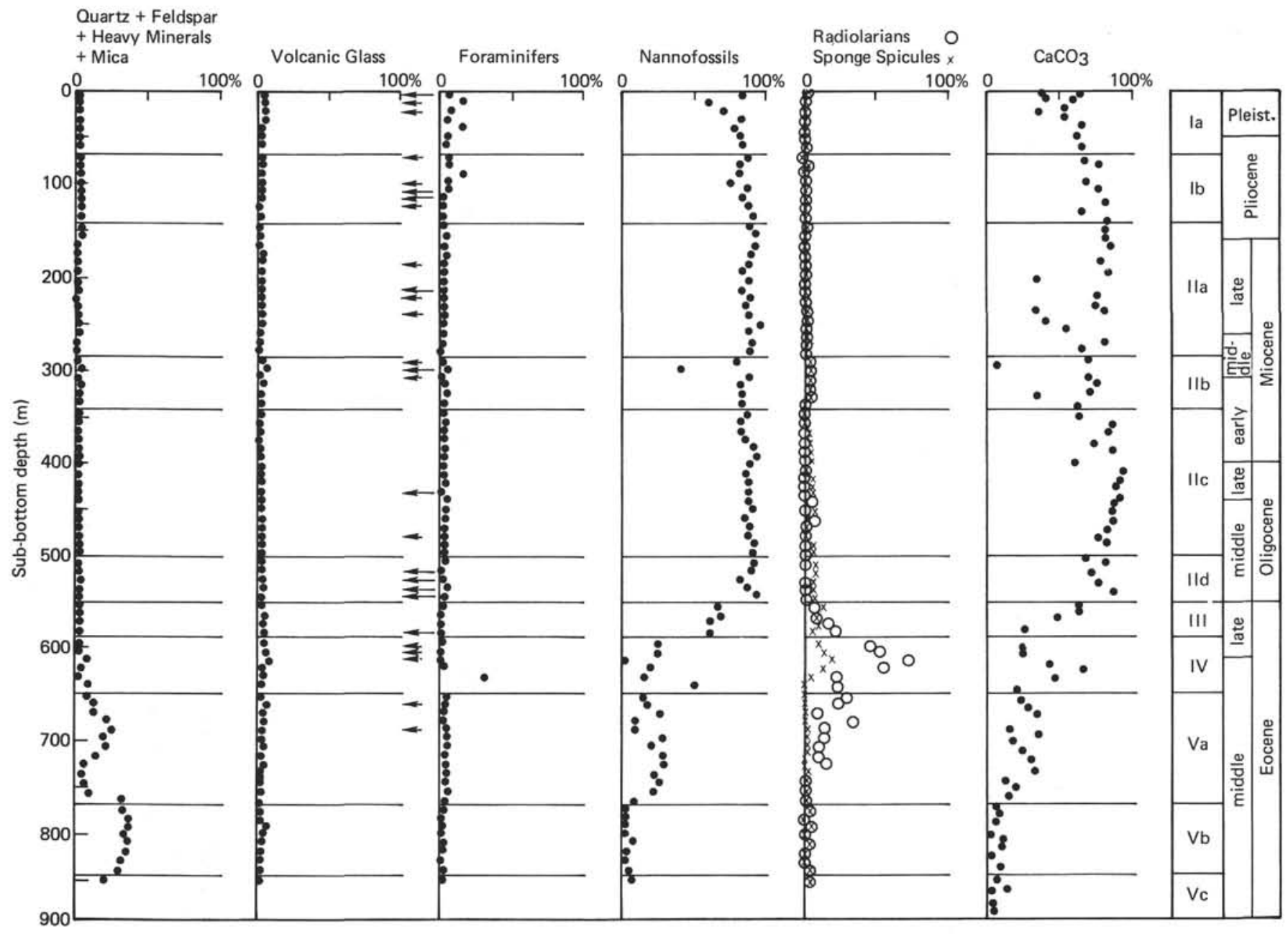

Figure 5. Composition of dominant lithology, Site 445, determined by smear-slide observation, with $\mathrm{CaCO}_{3}$ data from shore-based analysis. Plotted are average values of the components of dominant lithology in each core. Arrows in the volcanic glass column indicate the interbedded ashy layers as a minor lithology: long arrows, volcanic ash or tuff interbeds; short arrows, vitric interbeds.

sequence $\mathrm{T}(\mathrm{a}-\mathrm{e})$ and are definitely eroded, as shown by scoured, sharp basal contacts.

These sedimentary structures suggest that the larger part of unit II was resedimented by turbidity currents.

\section{Sub-Unit IIa}

This sub-unit consists mostly of nannofossil chalk. Clayey nannofossil chalk, marly nannofossil chalk, nannofossil mudstone, vitric nannofossil chalk, and nannofossil tuff occur as thin interbeds. Nannofossilforaminifer chalk and foraminifer-nannofossil chalk occur as very thin layers in the basal coarse-tail graded sequence. Dominant color of sediment is very pale brown to white.

Volcanic-glass shards are generally absent, but they range from 30 to 60 per cent. Siliceous fossils are very rare.

Graded sequences with bioturbation are common. Slump structures occur through the upper half of this sub-unit.

\section{Sub-Unit IIb}

This sub-unit consists dominantly of nannofossil chalk, with varying amounts of clayey, siliceous, and volcanic components. Nannofossil chalk is frequently interbedded with clayey nannofossil chalk and nannofossil mudstone. The dominant color of the sediments is the same as in sub-unit IIa.

Bioturbation is generally intense in the upper part of interval e; this tends to relate to increasing clay content, which produces color-bands.

\section{Sub-Unit IIc}

This sub-unit is similar to sub-unit IIb. It consists mainly of nannofossil chalk, with frequent interbeds of clayey nannofossil chalk, nannofossil mudstone, and foraminifer-nannofossil chalk. Generally, clayey components are abundant in the upper part of this sub-unit, and silty claystone only occurs in the uppermost part.

The sediments are dominantly very pale brown, pale brown, and brown. Color changes frequently form col- 
or-band alternations, mostly varying with the amount of clayey component, particularly in the upper part of the sub-unit.

Graded sequences, with associated bioturbation, are extensively developed. The thickness of the beds ranges from 50 to $450 \mathrm{~cm}$, mostly 80 to $100 \mathrm{~cm}$.

The middle to upper part of the sub-unit often includes thin beds of another type. They are usually 30 to $40 \mathrm{~cm}$ thick and rest upon a sharp contact; they consist of very dark-colored nannofossil mudstone, passing upward to lighter-colored nannofossil chalk, either with or without a basal silty layer.

Slump structures occur in the upper part and the lower part.

\section{Sub-Unit IId}

This sub-unit is dominantly nannofossil chalk, with varying proportions of clayey, siliceous, and volcanic components. The dominant color is pinkish white and pinkish gray to light gray and gray.

Volcanic ash is rather common throughout this subunit, both as interbeds and as an admixture.

Sedimentary structures are largely represented by graded bedding, intense bioturbation, and wavy lamination. In the upper half of the sub-unit, thick beds are intensely bioturbated. The intense bioturbation very likely obliterates the bedding which might have existed. The dark-colored (black to dark-gray), tuffaceous sediments, either clayey or non-clayey, have a unique sedimentary structure in the lower part of the sub-unit. They rest on nannofossil chalk with a sharp boundary and pass upward to nannofossil chalk, and the structure is very similar to that of the middle to upper part of subunit IIc. Dish structures are observed in Core 57-7.

\section{Unit III}

Unit III consists dominantly of siliceous nannofossil chalk with less than 10 per cent clay, radiolarians from 4 to 25 per cent, and sponge spicules 3 to 15 per cent (combined radiolarians and sponge spicules about 30 per cent maximum). The sediment is dominantly pinkish gray and light gray to gray.

Sedimentary structures are dominated by extensively developed parallel and wavy laminations (very thinbedded siliceous nannofossil chalk) and by intense bioturbation. Micro-faults are found in Core 61-3.

\section{Unit IV}

Unit IV is essentially characterized by frequent occurrence of radiolarians and well-indurated rocks such as siliceous limestone and "chert."

The middle to upper part is largely composed of radiolarite, with interbeds of more-calcareous, clayey, or ashy layers. Dominant color is olive gray to light brown to light yellowish brown. Siliceous fossils form 60 to 80 per cent of the total in the radiolarite, of which two thirds to four fifths consists of radiolarians and the remainder of sponge spicules.

Bioturbation is moderate to intense and extensive. Graded sequences are very poor, represented rarely by some intervals similar to $\mathrm{T}(\mathrm{d}, \mathrm{e})$. Instead, sandy to silty, very thin layers (a few millimeters) are thin bedded, without definite upper and lower boundaries.

In the middle part of this unit (Cores 64 and 65), are interbedded thin layers (10 to 20 centimeters thick) of "chert", siliceous limestone, and siliceous marly limestone.

Core recovery for the lower part of Unit IV (Cores 67 and 68) is not good. The lower part is composed largely of interbedded limestone and chert, very hard and massive to parallel thin-laminated. Color is very variable: light reddish brown, to very dark grayish brown, olive gray, greenish gray, and dark greenish gray. Visual discrimination of siliceous limestone and chert is very difficult.

A thin interbed of greenish gray graded sandstone (about 10 centimeters thick) is present in Core 68-1. It begins as a coarse grained sandstone just above a sharp basal contact (Core $68-1,95 \mathrm{~cm}$ ), and passes upward to faintly laminated to massive sandy limestone and welllaminated nanno limestone, successively. The sandstone contains many reworked foraminiferal tests of Asterocyclina $\mathrm{cf}$. penuria, Operculinoides sp., and smaller type foraminifers of benthic and planktonic forms.

\section{Unit $\mathbf{V}$}

Unit V is essentially characterized by abundant terrigenous components, in contrast to the overlying units. Although siliceous and calcareous biogenic components are present in considerable amount in the upper part, they decrease downward; on the contrary, terrigenous components of various grain size gradually increase and become coarser downward, and the lower part consists only of conglomerate and sandstone. This makes it possible to subdivide this unit into three sub-units.

The dominant lithology of unit $\mathrm{V}$ is mudstone, sandy mudstone and limestone (sub-units $\mathrm{Va}$ and $\mathrm{Vb}$ ) and conglomeratic sandstone (sub-units $\mathrm{Va}$ to $\mathrm{Vc}$ ), greenish gray to dark greenish gray in color.

The lithological suite of mudstone, sandy mudstone, and limestone shows very thin-bedded or laminated sedimentary structure in general. Different-sized grains, very fine sand to silt and mud, repeatedly occur in laminae of 1 to $2 \mathrm{~cm}$. Also, the extensive occurrence of thin-bedded $\mathrm{T}(\mathrm{d}, \mathrm{e})$ sequences characterizes this lithologic suite. Small-scale slump folds are rarely developed, and microconvolutions and microfaults are common features.

Conglomeratic sandstone is developed throughout unit $\mathrm{V}$. It occurs in sub-units $\mathrm{Va}$ and $\mathrm{Vb}$ as interbeds, thickness ranging from about 5 to $120 \mathrm{~cm}$. On the other hand, it makes massive, very thick beds in sub-unit Vc, which has little finer sediment.

Conglomerate is of debris flow origin and consists of variously sized clasts and calcareous fossil tests, mainly of larger foraminifers, with sandy grains and small amounts of muddy matrix of nannofossil-rich mudstone (Figure 6).

Most clasts are chaotically arranged, but tend to fine upward from pebble and granule size to granule and very coarse-sand size. Clasts are relatively larger in subunit Vc, attaining diameters up to $15 \mathrm{~cm}$. Clasts and 


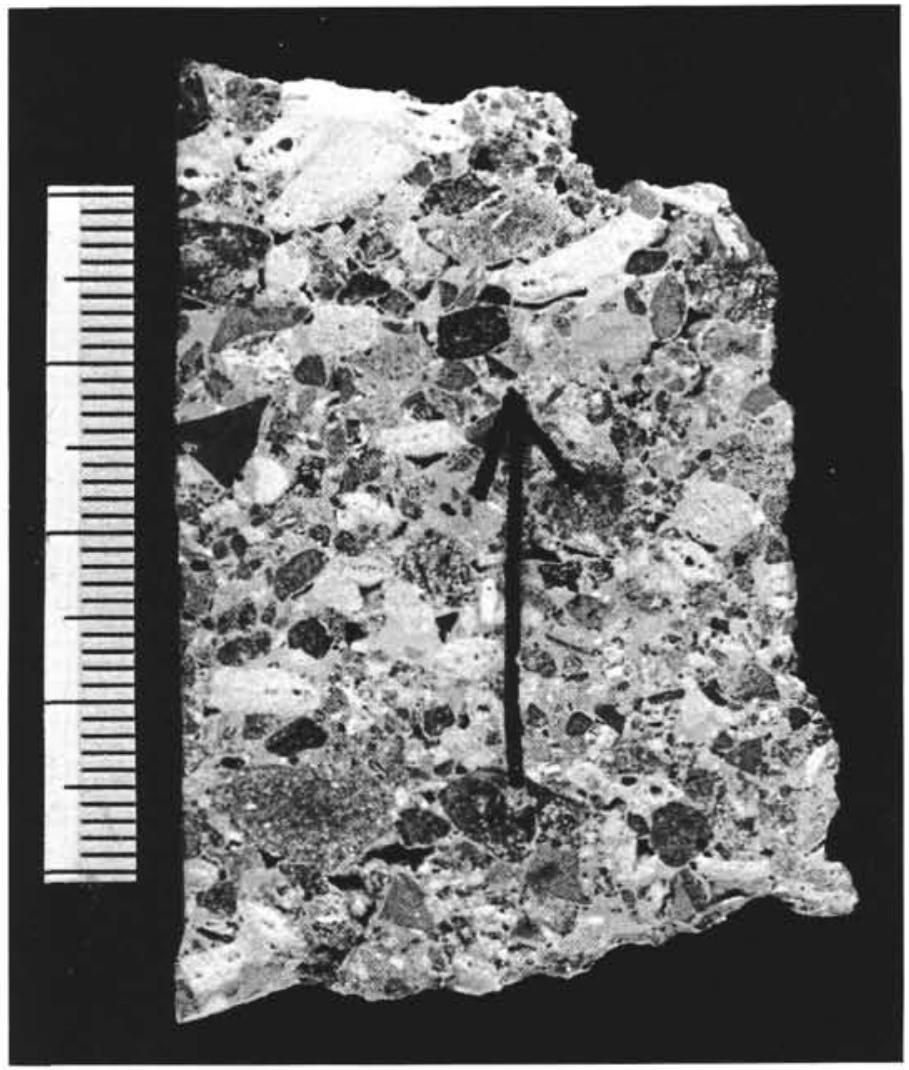

a
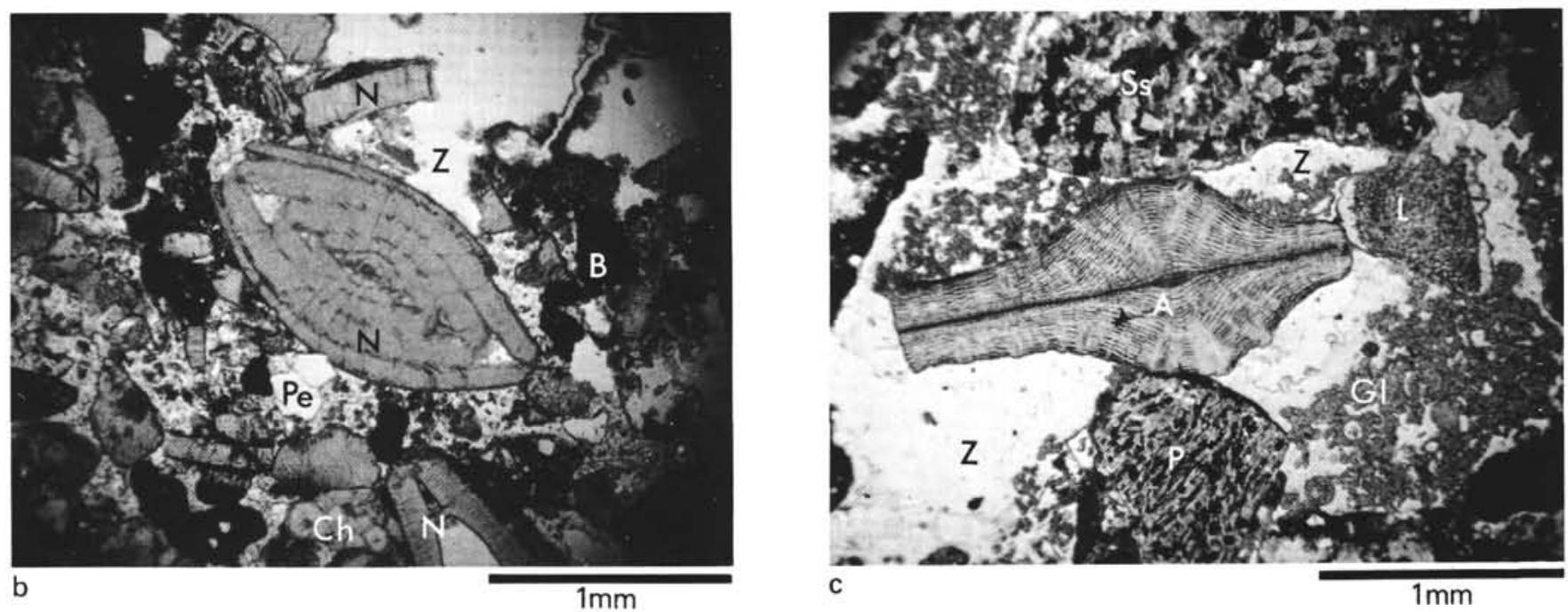

Figure 6. A. Photograph of slice sample of Nummulites-bearing conglomerate (Core 69-2, 64-68 cm; sub-unit Va). White spots are Nummulites tests, and dark spots are largely basalt and other igneous rocks. B. Nummulitesbearing conglomerate, showing tests of megalospheric form of Nummulites boninensis Hanzawa (Core 74-3, 59-61 $\mathrm{cm}$, sub-unit $\mathrm{Va}$ ). Besides Nummulites boninensis tests $(\mathrm{N})$, fragments of basalt $(B)$ and plagioclase (P1), and highly altered, chloritized volcanic clasts with oolitic structure (Ch) are scattered in cementation materials of zeolite (Z), shown by white fills. Lower nicol only. C. Nummulites-bearing conglomerate, showing tests of Asterocyclina $s p$. $c f$. A. penuria Cole (Core 69-2, 8-12 cm; sub-unit Va). Asterocyclina $s p$. $c f$. A. penuria (A), clasts of sandstone (Ss), basalt (B), and limestone (L), and fragmental grains of glauconitic nannofossil clay or tuff (G1) are filled with zeolite (Z) shown by white color. Lower nicol only. 
sand grains have various colors of green, brown, red, white, and black, and are variously shaped, angular to rounded. Under the microscope, the following rocks and minerals were distinguished: plagioclase phyric basalt (dominant), aphyric basalt (common), microdolerite (common), hornblende schist (rare), chert, sandstone, limestone, plagioclase (common), green hornblende (common), titaniferous augite (common), brown hornblende (rare), augite (common), olivine pseudomorphs (rare), chromian spinel (picotite) (common), epidote (rare). Heavy minerals (Sato, this volume) in conglomerate and sandstone include common hornblende and augite of volcanic origin, some minerals of schists, such as bluish-green amphibole and epidote, and chromite, which may have been derived from ultrabasic rock.

Calcareous fossil tests are megalospheric and microspheric forms of Nummulites boninensis (very abundant), Asterocyclina sp. cf. A. penuria, and Operculinoides sp., besides fragments of bryozoan and Ostrea. Microspheric forms of $N$. boninensis attain diameters of about $3 \mathrm{~cm}$, but most of the tests are broken. Nummulites and Asterocyclina are identical with those reported from sea bottoms of the Oki-Daito Ridge, the Daito Ridge, and the Amami Plateau at depths of 1500 to 2300 meters by Mizuno and Konda (1977) and Mizuno et al. (1977).

Both lithologic suites locally develop the perfect Bouma sequence, $\mathrm{T}(\mathrm{a}-\mathrm{e})$ : in Core $71-1$, conglomeratic sandstone forms the base of interval a and gradually passes upward to interval $b$, consisting of parallellaminated sandstone, the interval c consisting of very fine-grained sandstone with microconvolution, and the interval d of nannofossil limestone with weak parallel lamination. This sequence ends in the uppermost interval e, composed of massive, muddy nannofossil limestone $(71-1,19-89 \mathrm{~cm})$.

A primary sedimentary structure common to both lithologic suites in unit $\mathrm{V}$ is inclined bedding. In most cores and sections, beds dip at 5 to $10^{\circ}$ or more. The direction of dip frequently changes from core to core and (or) from section to section. This structure may have resulted from frequent resedimentation by largescale submarine slumping or sliding.

\section{Sub-Unit Va}

This sub-unit is dominantly thin-bedded and laminated, greenish-gray to dark-greenish-gray nannofossil mudstone, sandy mudstone, and nannofossil limestone, with interbeds of conglomerate and sandstone. In the upper part, mudstone, sandy mudstone, and limestone are often rich in partly dissolved radiolarians. Volcanic glass is usually present in amounts up to 3 per cent, but very locally reaches more than 10 per cent in the upper part.

Conglomerate and sandstone interbeds containing larger foraminifers are distributed throughout, but beds more than $50 \mathrm{~cm}$ thick occur in the middle to upper part (Cores 69-78).

\section{Sub-Unit Vb}

This sub-unit consists of dark-greenish-gray sandy mudstone, mudstone, and conglomerate. The general sedimentary features of sandy mudstone and mudstone are very similar to those of sub-unit Va, except for a general increase of sandy particles in mudstone. They are devoid of siliceous fossils and relatively poor in calcareous fossils. Conglomerate occurs as interbeds of 10 to $70 \mathrm{~cm}$ in the upper part and the lowest part.

\section{Sub-Unit Vc}

This sub-unit is exclusively dark-greenish-gray conglomerate, sandstone, and muddy sandstone. The upper part (Cores 90-92) consists of alternating conglomerate, sandstone, and muddy sandstone, whereas the lower part (Cores 93-94) consists of thick beds of conglomerate with larger clasts (up to $15 \mathrm{~cm}$ in diameter) and irregularly interbedded, ill-sorted sandstone. They show slump structures throughout.

\section{ORGANIC GEOCHEMISTRY}

Organic-carbon and nitrogen contents were measured for 74 sediment samples. Results of the analyses are reported elsewhere (Waples and Sloan, this volume) and are plotted in Figure 7. In the upper part of the section (0-525 m sub-bottom depth), where virtually all the samples are pelagic (biogeneous carbonate represents more than $80 \%$ of the sediment), the organic-carbon and nitrogen profiles are very similar to those reported for Sites 442,443 , and 444 for hemipelagic sediments. Organic-carbon and nitrogen values decrease steadily from the sediment water interface $(0.27$ and $0.38 \%$, respectively) to a depth of about 100 meters, below which they remain constant at about 0.06 and 0.015 per cent, respectively, throughout the pelagic-sediment interval.

Below 600 meters, the regularity of the organiccarbon profile is broken by anomalously high contents in many sediments. Most of the sediments from 600 to 885 meters are silty ( $-25 \%$ silt-size particles) or sandy (C $15 \%$ sand-size particles), and represent reworked sediments deposited during episodes of slumping and (or) turbid flow (Figure 8). It is likely, therefore, that the organic debris contained in these sediments is also reworked.

Benthic foraminifers throughout this interval indicate that the original depositional environment was relatively shallow, conditions favoring the input of relatively greater amounts of terrigenous organic debris.

The $\mathrm{C} / \mathrm{N}$ ratios for the silty material also support a terrestrial origin for much of the organic material. As grain size increases toward silt, there is a dramatic increase in the $\mathrm{C} / \mathrm{N}$ ratio. Because terrestrial plants generally are much depleted in nitrogen compared to aquatic organisms, the organic material in the silt fraction probably is terrestrial. The $\mathrm{C} / \mathrm{N}$ ratios of the sandy samples were about the same as for clays. This indicates 


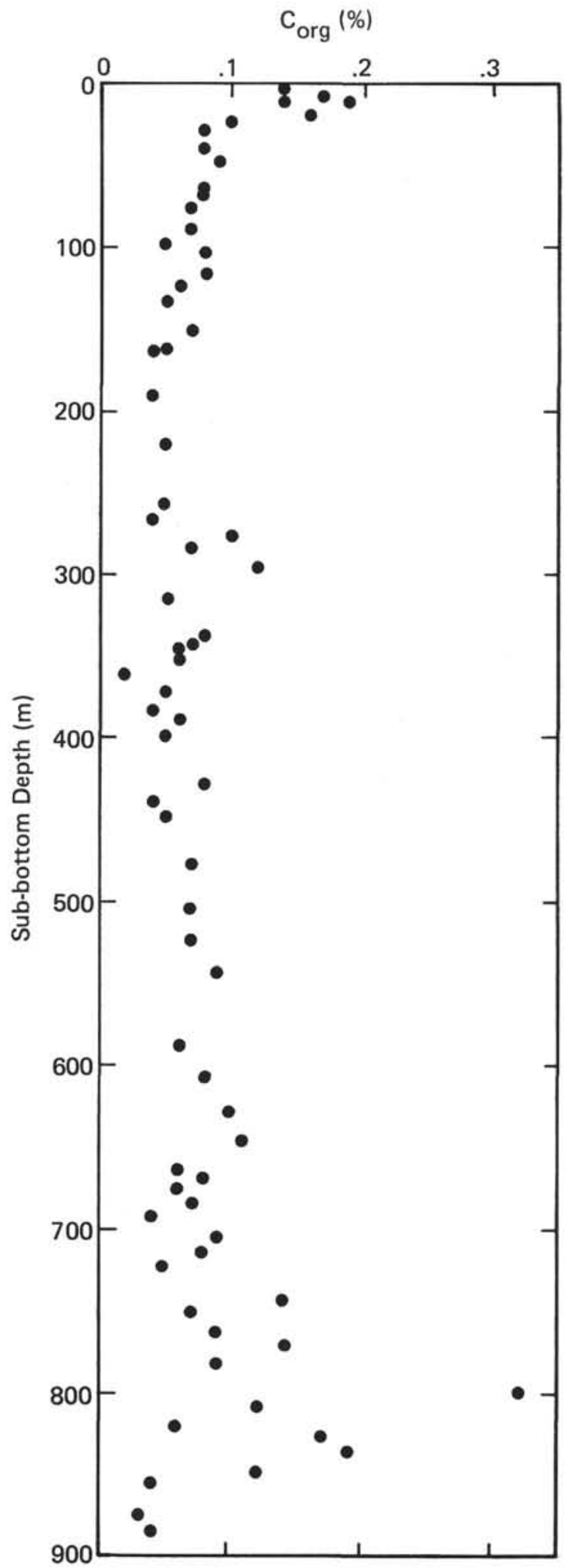

Figure 7. Per cent organic carbon versus depth (all sediments), Site 445.

that the sands did not bring much organic material with them; the small quantities of organic matter associated with these sediments are probably adsorbed on the claysized particles.

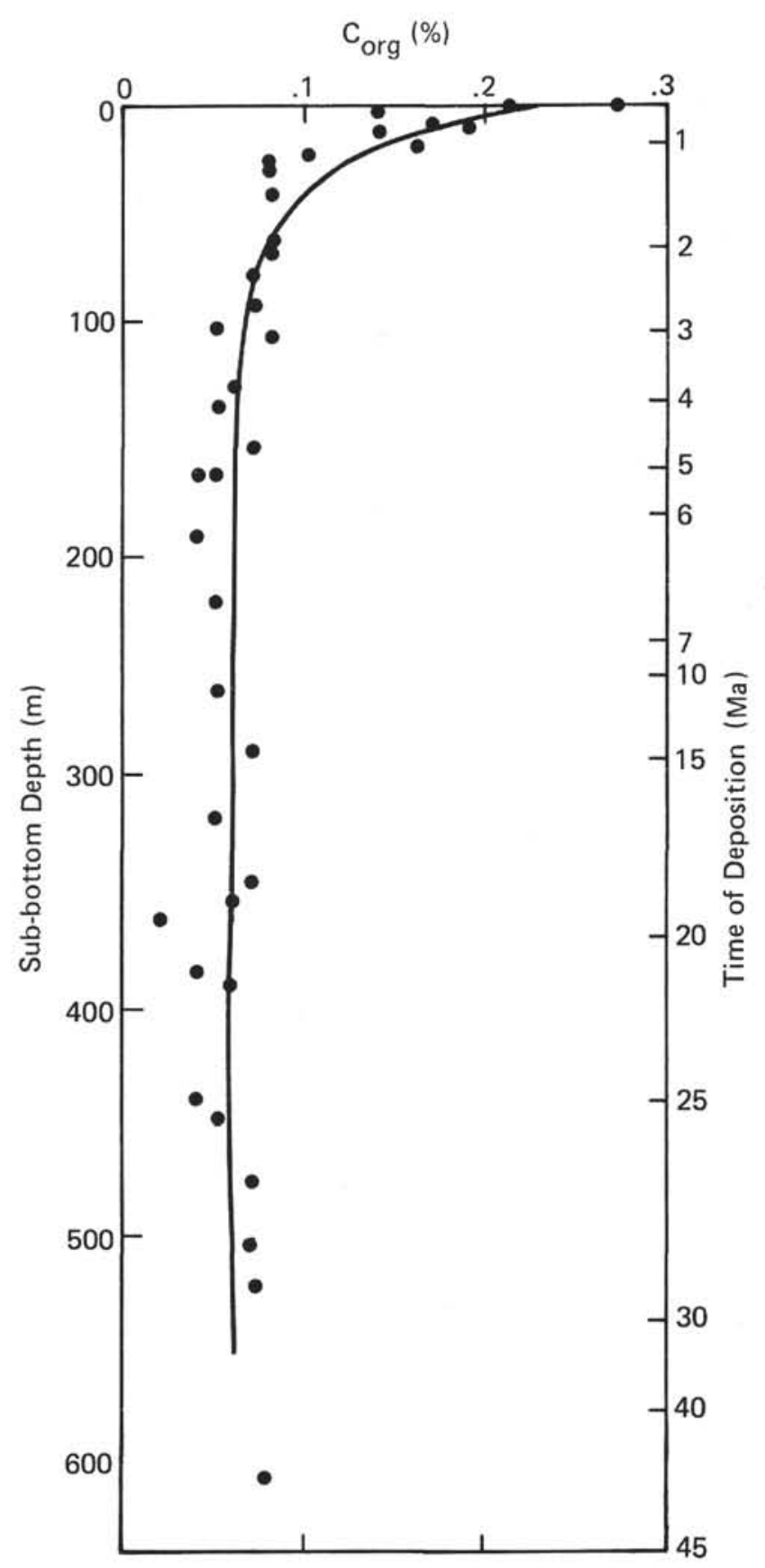

Figure 8. Per cent organic carbon versus depth (pelagic sediments), Site 445.

\section{INORGANIC GEOCHEMISTRY}

From Hole 445, 14 samples were taken for interstitial-water studies. The data are presented in Table 2 and on Figure 9.

$p \mathbf{H}$

$p \mathrm{H}$ averages 7.46, which is lower than the values for the IAPSO and surface-sea-water standards. $p \mathrm{H}$ varies somewhat down-hole, but does illustrate a trend to increase from the surface down to 296.5 meters, and from 
TABLE 2

Summary of Shipboard Geochemical Data for Hole 445

\begin{tabular}{lcccccccc}
\hline $\begin{array}{c}\text { Sample } \\
\text { (interval in cm) }\end{array}$ & $\begin{array}{c}\text { Sample } \\
\text { Number }\end{array}$ & $\begin{array}{c}\text { Sub-Bottom } \\
\text { Depth } \\
(\mathrm{m})\end{array}$ & $p \mathrm{H}$ & $\begin{array}{c}\text { Alkalinity } \\
(\mathrm{meq} / \mathrm{kg})\end{array}$ & $\begin{array}{c}\text { Salinity } \\
(\% \mathrm{oo})\end{array}$ & $\begin{array}{c}\mathrm{Ca}^{++} \\
(\mathrm{mmol} / \mathrm{l})\end{array}$ & $\begin{array}{c}\mathrm{Mg}^{++} \\
(\mathrm{mmol} / \mathrm{l})\end{array}$ & $\begin{array}{c}\mathrm{Cl}^{-} \\
(\%)\end{array}$ \\
\hline & $\begin{array}{c}\text { IAPSO } \\
\text { SSW }\end{array}$ & & 7.99 & 2.39 & 35.2 & 10.55 & 53.99 & 19.375 \\
& & 8.32 & 2.41 & 35.2 & 10.48 & 53.29 & 19.444 \\
$445-1-4,144-150$ & 28 & $5.94-6.00$ & 7.57 & 3.05 & 35.2 & 11.20 & 51.45 & 19.547 \\
$6-5,144-150$ & 29 & $53.94-54.00$ & 7.36 & 3.33 & 35.5 & 15.83 & 43.40 & 19.822 \\
$11-4,144-150$ & 30 & $99.94-100.00$ & 7.54 & 1.66 & 35.5 & 17.05 & 38.75 & 19.856 \\
$17-1,140-150$ & 31 & $152.40-152.50$ & 7.21 & 0.87 & 35.2 & 20.58 & 33.09 & 19.925 \\
$22-1,144-150$ & 32 & $199.94-200.00$ & 7.40 & 1.80 & 35.2 & 22.93 & 32.34 & 19.822 \\
$27-4,140-150$ & 33 & $251.90-252.00$ & 7.38 & 1.76 & 36.3 & 25.46 & 30.22 & 19.959 \\
$32-2,140-150$ & 34 & $296.40-296.50$ & 7.42 & 1.50 & 35.2 & 26.90 & 29.31 & 20.200 \\
$37-4,140-150$ & 35 & $346.90-347.00$ & 7.18 & 1.70 & 34.6 & 27.86 & 29.59 & 19.512 \\
$42-5,90-100$ & 36 & $395.40-395.50$ & 7.32 & 1.58 & 35.5 & 30.74 & 25.83 & 19.993 \\
$47-4,90-100$ & 37 & $441.40-441.50$ & 7.37 & 1.31 & 36.3 & 35.53 & 21.51 & 20.062 \\
$52-4,90-100$ & 38 & $488.90-489.00$ & 7.58 & 1.40 & 36.3 & 37.54 & 21.21 & 20.200 \\
$62-4,140-150$ & 39 & $584.40-584.50$ & 7.63 & 0.68 & 36.3 & 39.56 & 21.91 & 20.097 \\
$65-2,90-100$ & 40 & $609.40-609.50$ & 7.44 & 1.39 & 36.3 & 41.79 & 21.45 & 20.371 \\
$80-4,90-100$ & 41 & $754.90-755.00$ & 8.08 & 0.36 & 36.3 & 45.84 & 26.14 & 20.406 \\
\hline
\end{tabular}

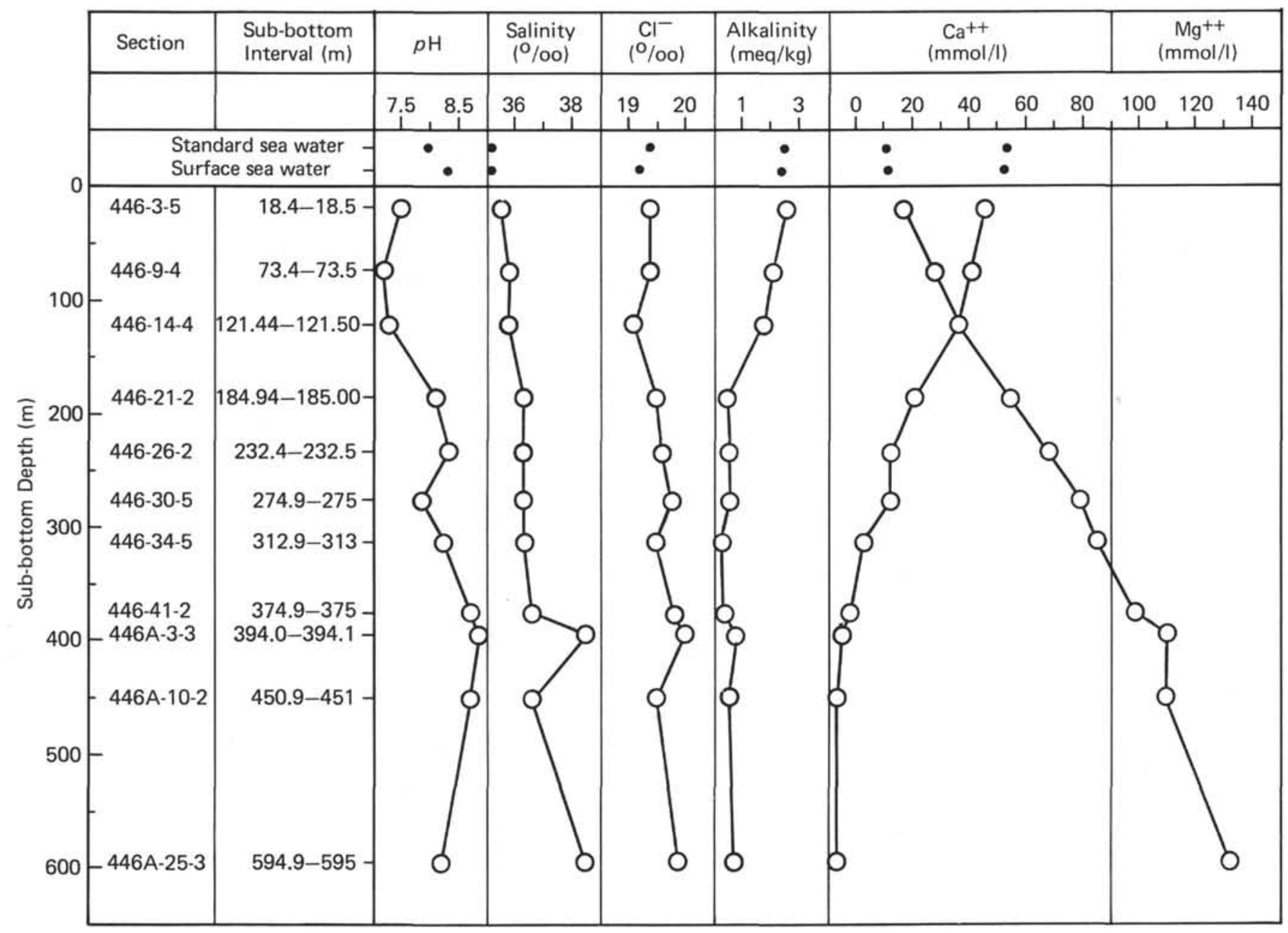

Figure 9. Interstitial-water geochemistry, Site 445. 
346.9 to 755 meters. The separation of these two trends approximates the boundary between sub-units IIb and IIc.

\section{Alkalinity}

Alkalinity averages $1.6 \mathrm{meq} / \mathrm{kg}$, lower than values for the two standards. Alkalinity shows little variation down-hole, except for a fairly steady decrease in values with increasing depth.

\section{Salinity and Chlorinity}

Salinity averages 35.7 per mill, and chlorinity 19.96 per mill, both averaging higher than the IAPSO and surface-sea-water standards. Both parameters increase with increasing depth, and, as expected, the trends of the two parameters correlate.

\section{$\mathrm{Ca}^{++}$and $\mathrm{Mg}^{++}$}

$\mathrm{Ca}^{++}$averages $24.5 \mathrm{mmol} / \mathrm{l}$, higher than the standard values of 10.55 and $10.48 . \mathrm{Mg}^{++}$averages 30.44 $\mathrm{mmol} / \mathrm{l}$, which is lower than the standard values o 53.99 and 53.29.

$\mathrm{Ca}^{++}$illustrates a definite trend of increasing with depth, whereas $\mathrm{Mg}^{++}$generally decreases with depth. The crossover for the two trends occurs in Core 37 $(346.9-347.0 \mathrm{~m})$, which marks the sub-unit $\mathrm{IIb} / \mathrm{IIc}$ boundary of very pale-brown and pale-brown, clayey nannofossil chalks; siliceous marly chalk; and white pinkish-gray and very pale-brown, clayey nannofossil chalks and nannofossil chalks.

The decrease of $\mathrm{Mg}^{++}$with depth is interrupted in Core 52 , below which $\mathrm{Mg}^{++}$values show a slight tendency to increase.

\section{BIOSTRATIGRAPHY}

Quaternary to middle-Eocene sediments were recovered at Site 445 (Table 3). This site, at a water depth of 3377 meters, is bordered by ridges in three directions with heights of 1000 to 2000 meters. This topographic feature created continuous and heavy reworking throughout the entire sequence.

Because the sedimentary basin is well above the $\mathrm{CCD}$, calcareous microfossils are abundant. The preservation of foraminifers and calcareous nannofossils proves that this site has been well above the CCD from the middle Eocene to the present. Although the history of subsidence is not indicated by present paleontological data, further study of benthic foraminifers may provide this information.

All paleontological evidence indicates a strong influence of tropical water during the middle Miocene and afterward. The relatively rare tropical nannofossils of the early Miocene and Oligocene periods may indicate slight cooling from the early Oligocene to the early Miocene at this site; also, foraminifers are smaller, and microforaminifers dominate the fauna in the same sequence.

The Pliocene/Pleistocene boundary was identified in Core 6 by foraminifers and nannofossils. Although a well-preserved modern radiolarian fauna was observed in Cores 1 and 2, radiolarians were not preserved in lower cores until the middle Miocene.

Foraminifers and nannofossils are abundant and well preserved in the Pliocene. Both the floral and faunal assemblages indicate Core 16 as the Miocene/Pliocene boundary.

Cores 17 to 28 represent the late Miocene and the middle and late early Miocene was recovered in Cores 29 to 35 . The first overgrowth of nannofossils is in the upper Miocene. The sediment became too hard for quick examination of foraminifer assemblages in the lower cores, except for sporadic soft layers. Therefore, the age determination almost exclusively relied upon nannofossils in the early Miocene and older sediments.

The Oligocene/Miocene boundary was identified in Core 41. The middle and late Oligocene was represented by Cores 41 to 57 , whereas the entire early Oligocene and the early middle Oligocene, representing at least 8 m.y., are represented by less than 15 meters of sediment. Therefore, a hiatus is suspected in the late Eocene to early middle Oligocene.

In the Oligocene and Eocene, which are mainly turbidite deposits, reworked fossils such as Nummulites, "larger" foraminifers, bryozoans, echinoid spines, and fragments of mollusks are common.

The abrupt appearance of a late-Eocene nannofossil assemblage was observed at Core 59-3. The top of the Eocene may be missing at this site. Radiolarians are abundant but not well preserved in Cores 63 to 65 , and absent below Core 65 .

Cores 66 through 89 represent the later middle Eocene. Both foraminifers and nannofossils confirm the age of the lower portion of this sequence as middle middle Eocene (47-48 m.y.).

\section{Foraminifers}

Continuous coring at Site 445 provided a foraminifer sequence from Neogene (N.23) through Paleogene (P.11/P.10; middle Eocene), suitable for biostratigraphic and environmental study.

In general, the foraminifers are abundant in the Pleistocene and Pliocene and decrease in number, size, and diversity from the Miocene to middle Eocene. They show no dissolution.

Although deposition is estimated to have been well above the CCD throughout the section encountered at this site, for some time spans foraminifers are rare or absent, and in some sections represented only by juveniles and microforaminifers. Therefore, fluctuating climate may have controlled this situation.

Only core-catcher samples were used for shipboard study, because rocks from the lower Miocene downward were so lithified (by foraminifer-study standards) that processing the material was time consuming.

Table 3 is a summary of the zonation of Hole 445 .

In Cores 1 through 5, planktonic and benthic foraminifers are abundant and well preserved; they indicate a Pleistocene age and deposition well above the CCD.

Cores 6 through 15 are Pliocene, and again the condition of the entire foraminifer fauna indicates that 
deposition was above the CCD. In Core 16, the Pliocene/Miocene (N.18; $\sim 5$ m.y.) boundary was detected; because this is defined by evolutionary appearances and concurrent ranges, precise definition must await study of the section samples. Cores 17 to 41 are Miocene. Throughout this interval, normal-sized foraminifers are very rare, and the index species used for the very short middle-Miocene zonation recognized in other parts of the world (i.e., Caribbean) were not seen.

Although the foraminifers are mostly in the microforaminifer size range, occasional normal-sized benthic forms indicate an open-sea ( $\geq 500$ meters) environment.

Fossils extracted from the indurated Oligocene are tiny and moderately well preserved. Based on the nannofossils, the Oligocene is estimated to range from within Core 41 to Core 59, Section 4. The Oligocene identified foraminifer zones are within Core 49 through Core 57 , approximately 26.5 to $36+$ m.y. In Cores 52 and 53-4, 68-70 cm, Nummulites, one of the "larger" foraminifers, was recovered from a greenish fragmented sandstone. Core 53 also contained other shallow-water foraminifers, such as Baculogypsina, Gypsina, Sphaerogypsina, and Rupertina. In the rubble, Eocene planktonic forms were also found, which indicate reworking in this section. The washed residue of $57, \mathrm{CC}$ is ash, but it contained many planktonic foraminifers of Eocene (?) age, encrusted with ash.

In Core 76, from 711.5 to 721 meters, the midEocene species Globorotalia spinulosa was encountered. This sample is dated approximately 44.5 to 45 m.y. Cores 79,80 , and 85 are also middle Eocene. The tentative foraminifer zonation shown in Table 3 indicates that sediments as old as 48 to $49 \mathrm{~m}$.y. were penetrated in this hole.

Both the megalospheric and microspheric generations of Nummulites occur in abundance in many of the Eocene cores from Core 60 downward. These may be related to the species Nummulites boninensis, described by Hanzawa in 1947 and recognized by Mizuno and Konda (1977) in dredge hauls near Daito and Oki-Daito Islands. The rocks in which these Nummulites occur also contain other shallow-water elements such as the benthic genus Amphistegina s.l. and fragments of bryozoans, pelecypods, echinoid spines and Ostrea. The fauna is undoubtedly reworked. However, the unbroken condition of the tests of the foraminifers may indicate a short distance of transport, therefore suggesting that this site is close to the source.

\section{Nannofossils}

Upper-Pleistocene to middle-Eocene nannofossils occur at this site. Nannofossils are abundant in all cores except the middle-Eocene sequence, in which they are sporadic. Because of heavy and continuous reworking, however, dating of cores was difficult in some intervals. All reworked specimens observed at this site represent a few zones prior to the time of redeposition, with a maximum time difference of several million years. Nannofossils are well preserved in the upper sequence (upper Miocene and above); only slight etching, without any sign of overgrowth, is recognized. Slight etching and moderate to heavy overgrowth, on the other hand, prevail in the lower cores. Recrystallization of nannofossils is strongest in the Oligocene and becomes relatively weak in the middle-Eocene turbidites. The age identification of cores is summarized in Table 3.

\section{Pleistocene}

Sections 1 to 5 of Core 1 belong to the Emiliania huxleyi Zone, whereas Section 1,CC contains an assemblage of the Ceratolithus cristatus Subzone. Reworked fossils are mostly Pliocene to early Pleistocene forms, but much older species, such as Cyclicargolithus floridanus, are also observed. Sections 2-2 to 3-5 belong to the Pseudoemiliania lacunosa Subzone, and a subtropical assemblage of the Crenalithus doronicoides Zone occurs in Section 4-1 to 6-3. The Pliocene/Pleistocene boundary was identified in Section 6-4.

\section{Pliocene}

Section 6-5 to $12-4$ belong to the late Pliocene (Discoaster brouweri Zone). The disappearance of Discoaster surculus identifies the base of the $D$. surculus Subzone at Section 9,CC. Heavy reworking prevents subdivision of this sequence. The early-Pliocene cores, however, are recognized at subzone levels. Core 13 belongs to the Discoaster asymmetricus Subzone, whereas Cores 14 and 15 represent the Sphenolithus neoabies Subzone. The Coratolithus rugosus Subzone is identified in Sections 16-2 to 16-4. The C. acutus Zone occurs in Cores 16,CC to 18-2, and the Miocene/Pliocene boundary lies within this interval.

\section{Miocene}

Miocene assemblages of abundant nannofossils occur in Cores 18-4 through 41-1. Section 18-4 belongs to the late late Miocene (Triquetrorhabdulus rugosus Subzone). Cores $18, C C$ to $25-3$ belong to the Discoaster quinqueramus Zone, and the first occurrence of Amaurolithus primus identifies the base of the $A$. primus Subzone in Section 22-2. The preservation of nannofossils is good until Core 23 ; it becomes mostly moderately good in the Miocene sequence. The Discoaster neohamatus Zone occurs in Cores 25-5 to 27-5, and Cores 27, CC to 28-4 belong to the Catinaster calyculus Subzone. Because Discoaster hamatus occurs only sporadically, the base of the Helicosphaera carter Subzone is not clear. The base of the Catynaster coalitus Zone is recognized in Section $29-4$ by only the occurrence of Discoaster kugleri in 29,CC. Cores 30-2 to 31-1 belong to the Coccolithus miopelagicus Subzone of early middle Miocene. Cores $31-3$ to $35, \mathrm{CC}$ represent the Helicosphaera ampliaperata Zone or the Sphenolithus heteromorphus Zone. The sporadic and rare occurrence of $H$. ampliaperata and reworking hampers identification of the boundary between these two zones. Similarly, the absence of Sphenolithus belemnos prevents division of the early-Miocene cores between sections 36-2 and 41-1. These cores belong to the Discoaster druggi Subzone or S. belemnos Zone. 
TABLE 3

Biostratigraphic Zones, Site 445

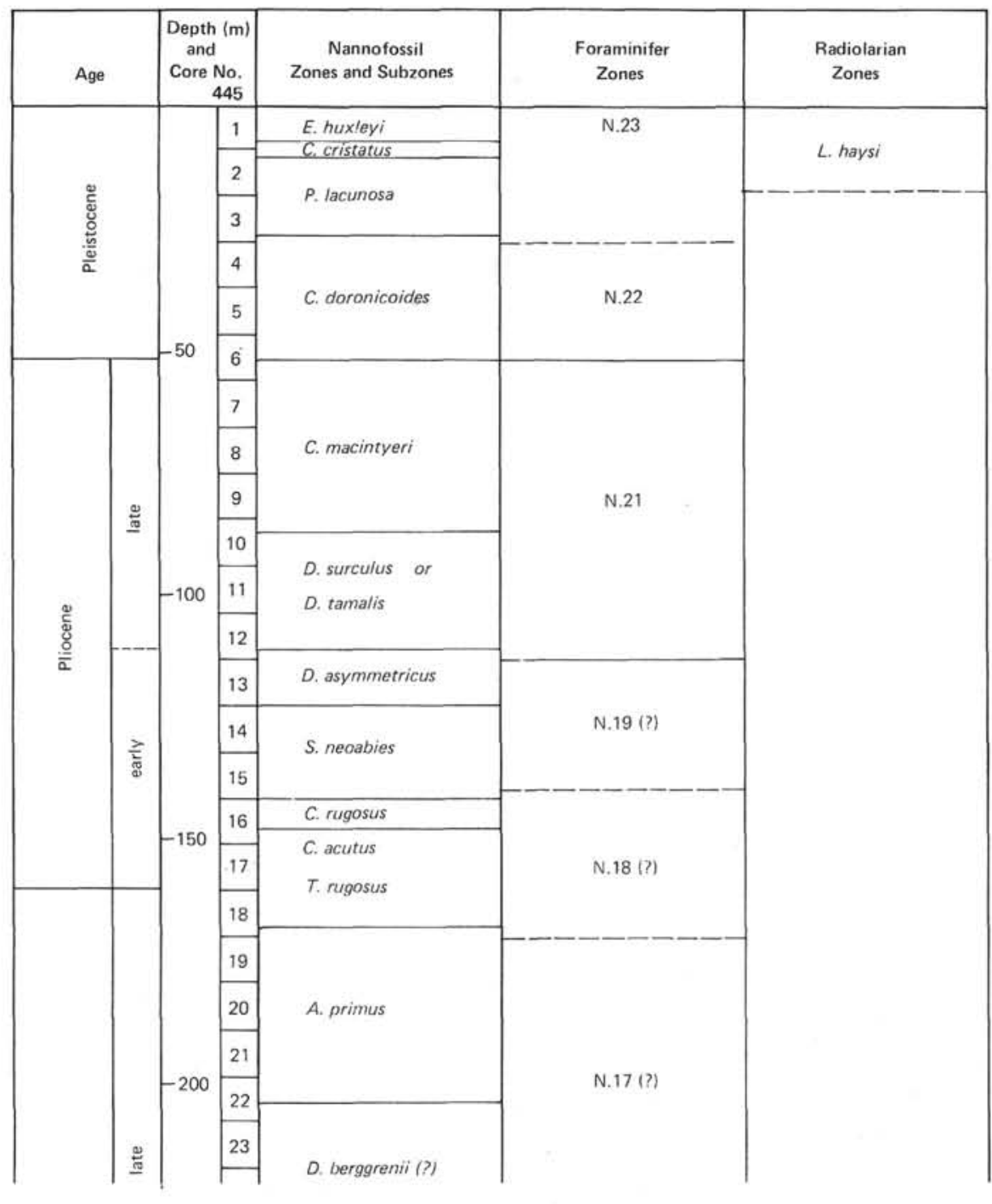

TABLE 3 - Continued

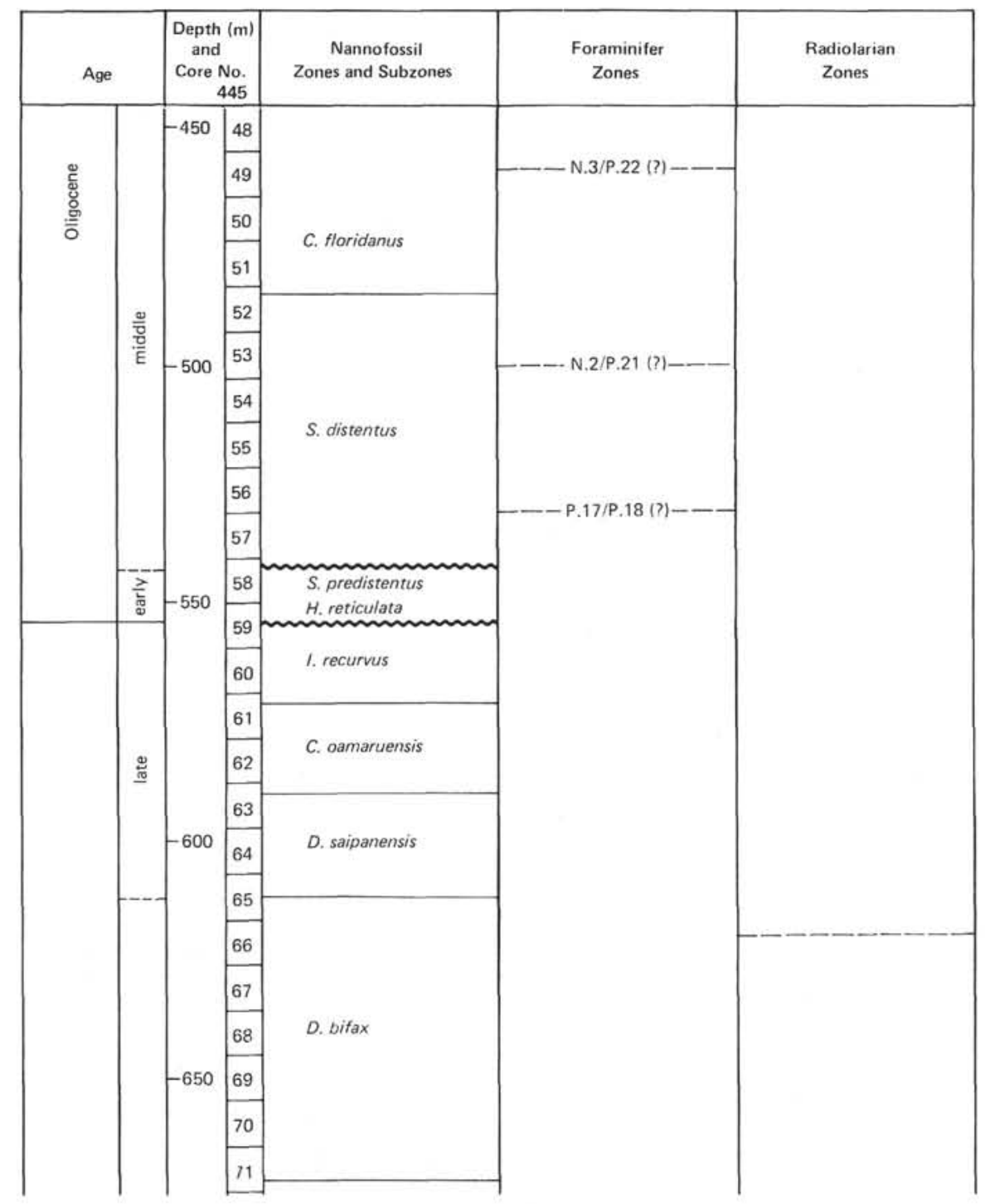




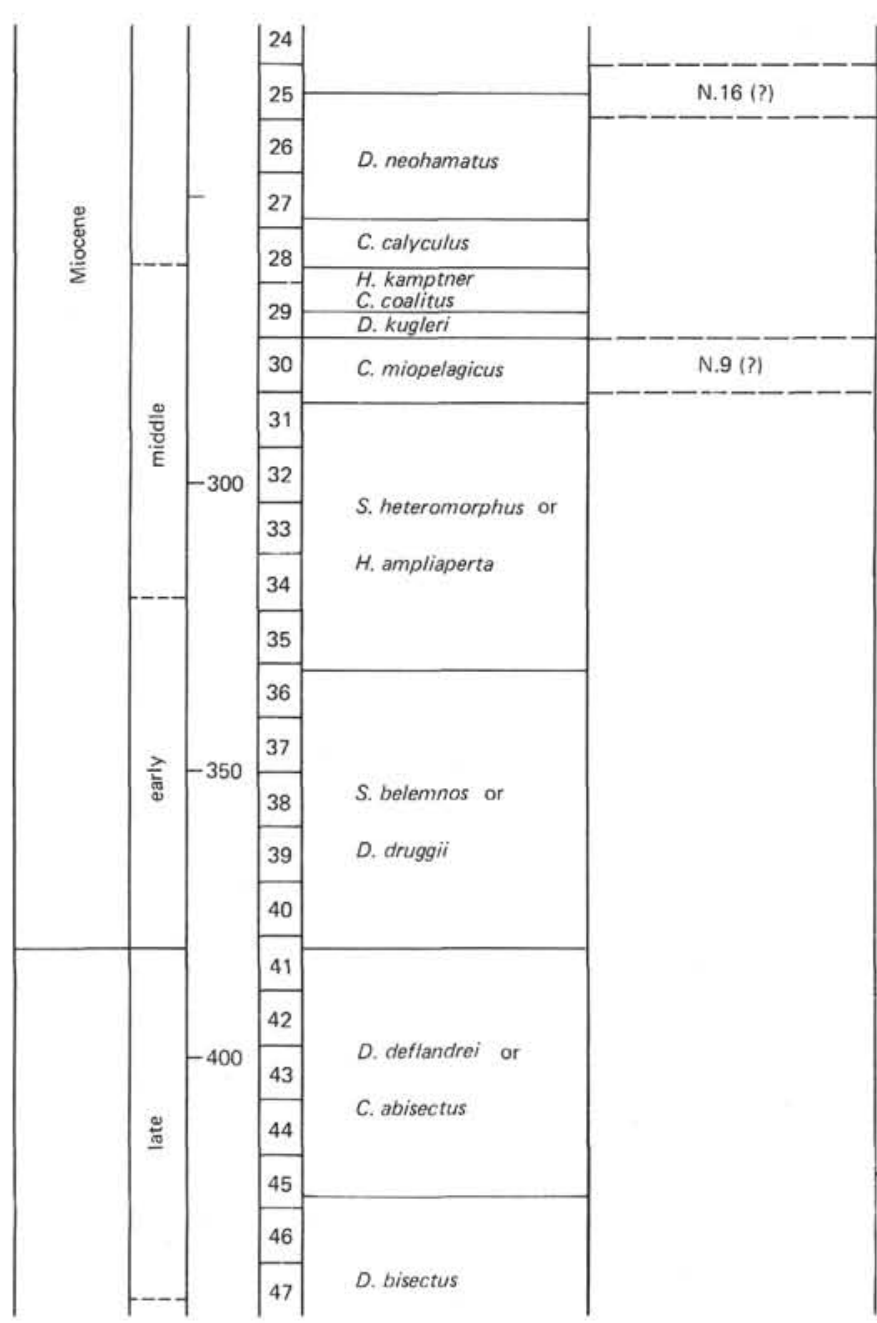

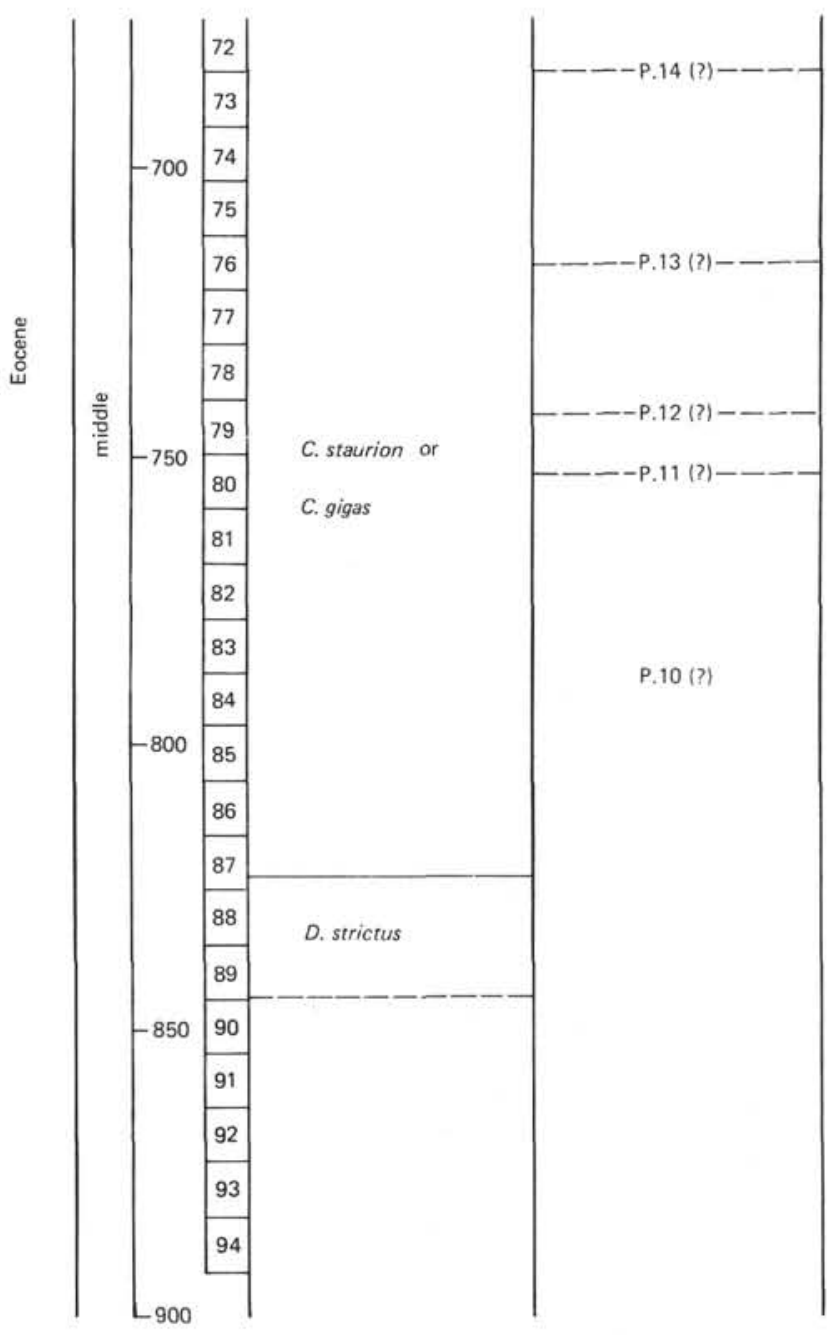




\section{Oligocene}

Cores 41-3 to 45-3 are assignable to the latest Oligocene or the earliest Miocene (Cyclicargotithus abisectus Subzone or Discoaster deflandrei Subzone). Cores 45, CC to 52-1 belong to the Sphenolithus ciperoensis Zone, and Section 47-3 represents the base of the Dictyococcites bisectus Subzone. Although rare, the consistent occurrence of Sphenolithus distentus identifies Cores 52-3 to 57,CC with the $S$. distentus Zone.

An assemblage of the early early to early middle Oligocene (Helicosphaera reticulata and Sphenolithus predistentus Zones) occurs in Cores 58-2 to 59-3. Because of heavy reworking, detailed age identification is impossible for this interval. Considering the length of time (8 m.y.) represented by this short sequence of sediment, a hiatus is suspected. The sudden increase of Reticulofenestra umbilica and Discoaster saipanensis below Sections 58-2 and 59-4 respectively suggests hiatuses at the top and at the base of this sequence. Although rare, Isthmolithus recurvus occurs consistently through this sequence and in the uppermost Eocene cores. This species is seldom preserved in low-latitude area, whereas it is common in high-latitude areas (Bukry, 1975). At nearby Sites 290, 291 and 292, this species was not observed. The cause of the sporadic occurrence of this species at this site is not clear at present.

\section{Eocene}

The first occurrence of $I$. recurvus in Section $60, \mathrm{CC}$ identifies the base of the upper-Eocene $I$. recurvus Subzone. Although Chiasmolithus oamaruensis does not occur at this site, extinction of $C$. grandis indicates the base of the C. oamaruensis Subzone in Section 63-1. Cores 63-3 to $65-1$ and $66-1$ to $71-4$ belong to the $D$. saipanensis and Discoaster bifax Subzones, respectively. Below Core 65, hitherto ubiquitous nannofossils are scarce and sporadic. The Chiasmolithus gigas and Coccolithus staurion Subzones of the middle middle Eocene are identified in Cores 72-1 to 87-2. The turbidites of Cores 88 and 89 contain a moderately well-preserved assemblage of the Discoaster strictus Subzone (47.0-48.0 m.y.). The oldest reworked fossils found in these cores are Discoaster lodoensis and D. sublodoensis. Both species are considered to have become extinct about 48.0 $\mathrm{Ma}$. Cores 90 and 91 contain a few poorly preserved nannofossils; the assemblage does not justify age identification, and Cores 92 to 94 are barren of nannofossils.

\section{Radiolarians}

Radiolarians are sporadic at Site 445. Only Cores 1 and 2 had well-preserved and abundant radiolarians. Radiolarians in any abundance are again encountered only in Cores 63 through 65 , but they are not well preserved.

Cores 1 and 2 are Pleistocene to Holocene and contain species which are still living in today's seas (Spongaster tetras, Euchitonia furcata, and Ommatartus tetrathalamus). Cores 3 through 30 are barren, and Cores 31 through 34 have a few middle-Miocene species, with slight lower-Miocene reworking. Many cores from 35 to 58 are barren, but some contain abundant unidentified fragments of radiolarian spines and lattices.

Below the chert, the sediments are coarse-grained (sandy mudstones grading into conglomerates), and radiolarians are not preserved in this type of sedimentary regime. The moderately well-preserved radiolarians in Cores 63 through 65 contain species of the Eocene and Oligocene genera Eusyringium, Podocyrtis, Dorcadospyris, and Theocyrtis. No radiolarian zone can be assigned to Core 63 , but Cores 64 and 65 belong to the late Eocene (Podocyrtis chalara Zone). There are no radiolarians preserved below Core 65 .

\section{SEDIMENTATION RATE}

An age-depth plot is shown in Figure 10. The ages of the sediment were obtained using the time-scales of Berggren (1972), Berggren and Van Couvering (1974), and Bukry (1975), and the modified Miocene time scale of Saito (1977). Table 4 shows sediment accumulation rates calculated for each stratigraphic unit.

The sediment accumulation rates show a systemic change down-hole. They are moderate to moderately high for the Pleistocene and Pliocene foraminifernannofossil oozes of unit I, and moderate for the Oligocene and Miocene chalks of unit II. The rates are lowest 9.3 during the early Oligocene and late Eocene, during deposition of the radiolarites and chert of unit III; they increase drastically in sandstones, conglomerates, and mudstones of unit V (early late and middle Eocene). The sediment accumulation rate curve shows remarkable similarity to the trend of the accumulation rate curve for Site 286 in the Hebrides Basin (Andrews, Packham, et al., 1975), in particular, and both Sites 285 and 286 in general (Klein, 1975). There, the high rates of accumulation were characteristic of debris-flow conglomerates and turbidite sandstones; the lowest rates were characteristic of biogenic, pelagic carbonate oozes, and intermediate and moderate rates were characteristic of resedimented nannofossil oozes.

The explanation for the sediment accumulation rate pattern at Site 286 is the same for Site 445 . The highest rates of sediment accumulation are for the turbidite sandstones and the pebble to granule gravel conglomerates of slump and debris-flow origin of unit V. The lowest rates are characteristic of the unit IV radiolarites and cherts. Intermediate values are characteristic of units I, II, and III, where evidence of resedimentation by subaqueous gravity processes is common. That evidence includes preserved slump blocks, folds and faults, and graded foraminifer sands organized into partial Bouma sequences $[\mathrm{T}(\mathrm{a}, \mathrm{b}, \mathrm{e})]$ produced by turbidity currents. The slight increase in sediment accumulation rates for the Pleistocene oozes may well reflect higher productivity of the Kuroshio Current, detected at Sites 296 and 297 by Karig, Ingle, et al. (1975).

\section{PALEOMAGNETISM}

Site 445 is a single-bit hole with about 900 -meter penetration into the sediment cover. The topmost 200 


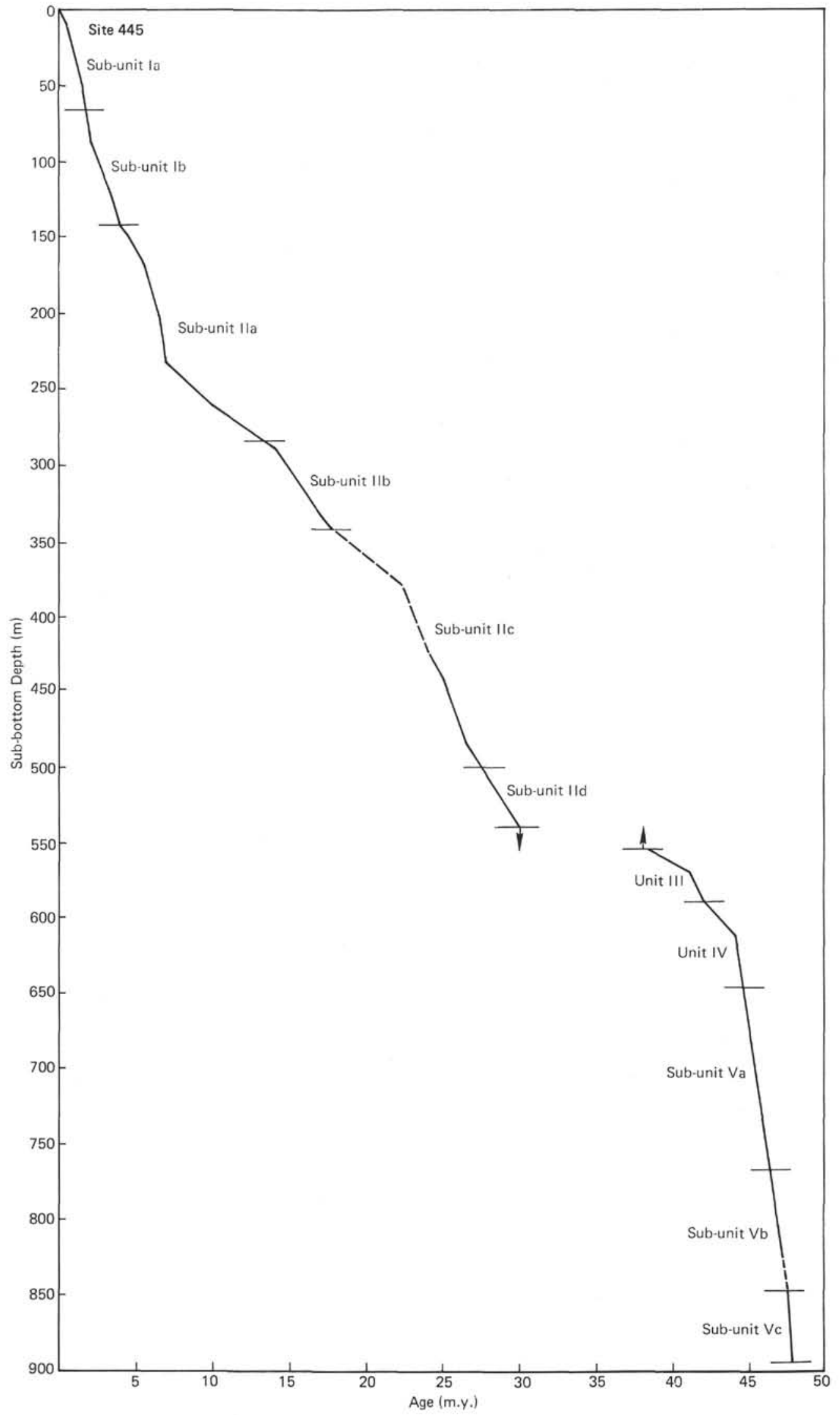

Figure 10. Sediment accumulation rate curve for Site 445, based on biostratigraphic age determinations. 
TABLE 4

Sedimentation Rates, Site $\mathbf{4 4 5}$

\begin{tabular}{lccc}
\hline & $\begin{array}{c}\text { Depth } \\
(\mathrm{m})\end{array}$ & $\begin{array}{c}\text { Interval } \\
\text { Thickness } \\
(\mathrm{m})\end{array}$ & $\begin{array}{c}\text { Sedimentation } \\
\text { Rate } \\
(\mathrm{m} / \mathrm{m} . \mathrm{y} .)\end{array}$ \\
\hline Ia & $0.0-65.5$ & 65.5 & 36.9 \\
Ib & $65.5-141.8$ & 76.3 & 34.7 \\
IIa & $141.8-284.0$ & 142.2 & 16.0 \\
IIb & $284.0-341.0$ & 57.0 & 13.9 \\
IIc & $341.0-502.5$ & 161.5 & 16.5 \\
IId & $502.5-551.7$ & 49.2 & 18.9 \\
III & $551.7-588.9$ & 37.2 & 9.3 \\
IV & $588.9-645.0$ & 56.1 & 22.4 \\
Va & $645.0-768.5$ & 123.5 & 72.6 \\
Vb & $768.5-844.5$ & 76.0 & 95.0 \\
Vc & $844.5-892.0$ & 47.5 & 237.5 \\
\hline
\end{tabular}

meters consists of relatively soft sediments. In the other part, the sediments are lithified and mechanically stable. Paleomagnetism samples were taken on an average of 1.5 meters in the recovered cores. Three hundred and twelve of them were used for NRM and AF-demagnetized NRM measurements. Changes in NRM during AF treatment are significantly different from sample to sample, as shown in Figure 11. Because stepwise AF demagnetization for all of the samples was impossible within a limited time schedule, the AF demagnetization

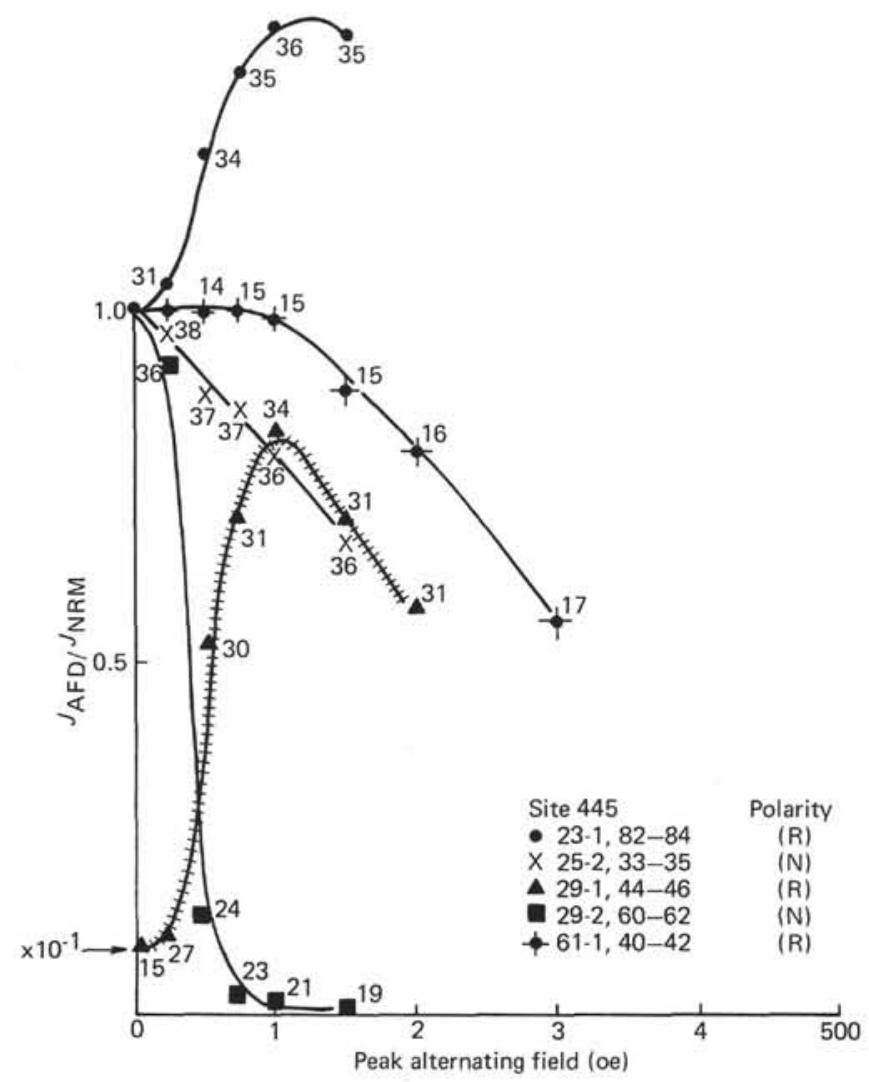

Figure 11. Change in sediment NRM intensity during $A F$ demagnetization. Rounded numbers attached to each point represent absolute inclination values $o b$ tained after AF demagnetization. was carried out in a 150 -oe $\mathrm{AF}$, decreasing to zero at a constant rate. Measuring and AF demagnetizing techniques are described in the Site 442 report. On account of a large number of samples available at this site, a rigorous examination of paleomagnetism stability was applied to distinguish paleomagnetically reliable samples. Examination was according to the following criteria: (1) intensity ratio of AF-demagnetized remanent magnetization to the initial NRM falls between 2 and $1 / 2 ;(2)$ angular shift of NRM during AF demagnetization is less than 5 degrees; (3) the Koenigsberger ratio is larger than 10 .

Ninety-five samples of 312 were retained for further analyses. All the data on sample positions and measurements of remanent magnetization are listed in Table 5 . Normal and reversed sequences of cores are diagrammatically shown in Figure 12. In the last part of Figure 12 , Cores 68 through 90 , the polarity column is left blank for two reasons. One, in the lowermost 200 meters of the sediment cover NRM inclination becomes smaller, and therefore the polarity change of the geomagnetic field cannot be determined through NRM inclination values alone. Two, this layer consists mostly of mudstones, and only a small portion of the recovered cores were found useful. In Figure 13A, absolute inclinations of AF-demagnetized stable NRM are plotted against sub-bottom depth. In Figure 13B, original NRM intensity values (mean for every 10 meters) are plotted against sub-bottom depth. AF-demagnetized absolute NRM inclination values are divided into four groups for 200-meter sub-bottom intervals, and statistical treatment was applied. Results are listed in Table 6. Latitude of the Daito Ridge is calculated upon the assumption that the mean virtual pole position is exactly equal to the present geographical pole position throughout the last 45 m.y.

Table 6 also includes the latitude of Site 445 in the past. The results are plotted in Figure 14. The position of the Shikoku Basin deduced from the NRM inclination data at Sites 442 through 444 is also shown in the figure for comparison. It seems likely that the scatter of data is significantly dependent on the mechanical strength of the sediment. Statistical analysis leads us to a tentative evaluation of a minimum distance of migration of the Daito Ridge during the last $45 \mathrm{~m}$.y. Supposing that the ridge was situated at 5 degrees north latitude, due south of the present location, and that it continuously drifted northward to reach the present position, the distance of movement is about $2000 \mathrm{~km} \mathrm{(4.4}$ $\mathrm{cm} / \mathrm{yr}$ ). The other implication of Figure $13 \mathrm{~b}$ is a high incidence of subaerial eruptions at this locality during the probable Eocene, represented by a thick mudstone layer in the bottom 200 meters of the hole. It is likely that the mudstone contains ferromagnetic minerals (probably titanomagnetite) more abundant by one order of magnitude than in the other sediments. AF demagnetization mode shows that the ferromagnetic particles are finegrained, just as in the chilled margin of an oceanic basalt. This is possible when a tremendous amount of finegrained materials falls to form a thick tuff layer. Actually, some of the tuffs and welded tuffs on land show a 
TABLE 5

TABLE 5 - Continued

\begin{tabular}{|c|c|c|c|c|c|c|}
\hline \multirow{2}{*}{$\begin{array}{c}\text { Sample } \\
\text { (interval in } \mathrm{cm} \text { ) }\end{array}$} & \multirow{2}{*}{$\begin{array}{l}\text { Sub- } \\
\text { bottom } \\
\text { Depth } \\
\text { (m) }\end{array}$} & \multirow{2}{*}{$\begin{array}{l}J_{\text {NRM }} \\
\left(10^{-5}\right. \\
\text { gauss) }\end{array}$} & \multirow{2}{*}{$\begin{array}{l}\text { Suscepti- } \\
\text { bility } \\
\left(10^{-5}\right. \\
\text { gauss/oe })\end{array}$} & \multicolumn{2}{|c|}{ Inclination } & \multirow{2}{*}{$\begin{array}{l}\text { Polar- } \\
\text { ity }\end{array}$} \\
\hline & & & & NRM & AFD & \\
\hline $445-2-1,86-88^{\circ}$ & 9.37 & 1.97 & 0.23 & 26.7 & 31.9 & + \\
\hline $2-2,116-118^{*}$ & 11.17 & 1.98 & 0.17 & 38.4 & 37.5 & + \\
\hline $2-3,114-116^{*}$ & 12.65 & 2.44 & 0.07 & 10.5 & 10.5 & + \\
\hline $3-1,15-17$ & 18.16 & 0.27 & 0.11 & -4.6 & -1.4 & - \\
\hline $3-2,100-102$ & 20.51 & 1.86 & 0.24 & 50.0 & 51.3 & + \\
\hline $3-3,76-78^{*}$ & 21.77 & 2.74 & 0.16 & 43.6 & 44.4 & + \\
\hline $3-4,57-59 *$ & 23.08 & 0.88 & 0.10 & -31.1 & -29.7 & - \\
\hline $3-5,21-23$ & 24.22 & 0.68 & 0.21 & -28.7 & -28.5 & - \\
\hline $3-6,109-111^{*}$ & 26.60 & 1.14 & 0.17 & -9.4 & -14.9 & - \\
\hline $4-1,14-16^{*}$ & 27.65 & 2.06 & 0.22 & 22.6 & 25.1 & + \\
\hline $4-4,40-42$ & 32.41 & 0.23 & 0.14 & -45.5 & -56.5 & - \\
\hline $4-5,52-54$ & 34.03 & 0.46 & 0.19 & -1.7 & -22.2 & \\
\hline $4-6,21-23$ & 35.22 & 0.82 & 0.19 & -19.0 & -9.2 & - \\
\hline $5-1,93-95$ & 37.94 & 0.94 & 0.22 & -46.4 & -45.1 & - \\
\hline $5-2,137-139$ & 39.88 & 1.01 & 0.22 & 72.6 & 39.4 & + \\
\hline $5-3,11-13$ & 40.12 & 0.99 & 0.25 & -16.6 & -23.5 & - \\
\hline $6-1,38-40$ & 46.89 & 0.28 & 0.19 & -20.8 & -40.6 & - \\
\hline $6-2,137-139$ & 49.36 & 0.46 & 0.17 & 74.3 & 30.5 & + \\
\hline $6-3,115-117$ & 50.66 & 1.01 & 0.24 & -1.8 & -18.3 & - \\
\hline $6-4,86-88$ & 51.87 & 0.13 & 0.24 & -0.8 & -29.2 & - \\
\hline $6-5,71-73$ & 53.22 & 2.26 & 0.48 & 30.1 & 21.8 & + \\
\hline $6-6,79-81$ & 54.80 & 1.21 & 0.31 & 16.1 & 4.2 & + \\
\hline $7-6,88-90$ & 64.39 & 1.03 & 0.25 & 36.4 & 28.3 & + \\
\hline $8-1,138-140$ & 66.89 & 0.57 & 0.26 & -15.2 & -15.6 & \\
\hline $8-2,138-140$ & 68.39 & 1.10 & 0.26 & 36.7 & 41.0 & + \\
\hline $8-3,138-140$ & 69.89 & 0.05 & 0.25 & 45.3 & 60.4 & + \\
\hline $8-4,138-140$ & 71.39 & 0.28 & 0.33 & -50.1 & -49.6 & - \\
\hline $8-5,138-140$ & 72.89 & 0.51 & 0.29 & 59.0 & -23.2 & $+1-$ \\
\hline $10-5,144-146$ & 91.95 & 1.27 & 0.32 & 55.6 & 51.1 & + \\
\hline $11-2,69-71$ & 96.20 & 1.13 & 0.33 & 24.3 & 23.9 & + \\
\hline $11-3,80-82$ & 97.81 & 0.11 & 0.33 & -65.0 & -80.2 & - \\
\hline $11-4$ & $<100$ & 0.30 & 0.37 & -31.1 & -46.4 & - \\
\hline $11-5$ & $>100$ & 0.73 & 0.36 & -7.0 & -11.6 & - \\
\hline $12-1,95-97$ & 104.46 & 0.93 & 0.21 & 52.0 & 53.6 & + \\
\hline $12-2,95-97^{*}$ & 105.96 & 1.05 & 0.21 & -82.6 & -83.5 & - \\
\hline $12-3,95-97^{*}$ & 107.46 & 2.37 & 0.40 & 29.4 & 31.0 & + \\
\hline $12-4,95-97$ & 108.96 & 0.76 & 0.26 & 31.7 & 29.7 & + \\
\hline $13-1,72-74$ & 113.73 & 0.23 & 0.25 & 34.5 & 35.2 & + \\
\hline $13-2,72-74$ & 115.23 & 0.049 & 0.34 & 37.6 & -34.5 & $+1-$ \\
\hline $13-3,72-74$ & 116.73 & 0.51 & 0.23 & 43.2 & 47.5 & + \\
\hline $13-4,72-74$ & 118.23 & 0.078 & 0.29 & -40.0 & -66.8 & - \\
\hline $14-1,58-60$ & 123.09 & 0.010 & 0.16 & -68.4 & -50.8 & - \\
\hline $15-1,20-22$ & 132.21 & 0.028 & 0.21 & -17.6 & -37.2 & - \\
\hline $15-2,20-22$ & 133.71 & 1.39 & 0.31 & -51.1 & -49.8 & - \\
\hline $16-1,45-47$ & 141.96 & 0.10 & 0.15 & 48.0 & 31.6 & + \\
\hline $16-2,45-47$ & 143.46 & 0.79 & 0.23 & 22.8 & 13.0 & + \\
\hline $16-3,45-47$ & 144.96 & 0.88 & 0.17 & 43.2 & 49.6 & + \\
\hline $17-2,24-26$ & 152.75 & 0.40 & 0.16 & 73.6 & 69.7 & + \\
\hline $18-1,99-101$ & 161.50 & 0.25 & 0.19 & -0.0 & -40.7 & - \\
\hline $18-5,21-23$ & 166.72 & 1.31 & 0.17 & 42.2 & 24.0 & + \\
\hline $19-2,05-07$ & 171.56 & 1.33 & 0.17 & 21.8 & 11.9 & + \\
\hline $19-3,05-07$ & 173.06 & 0.44 & 0.17 & 21.9 & -30.6 & $+1-$ \\
\hline $20-1,100-102$ & 180.49 & 0.35 & 0.18 & 50.8 & -13.3 & $+1-$ \\
\hline $20-2,100-102$ & 181.99 & 0.16 & 0.17 & 30.7 & -83.9 & $+1-$ \\
\hline $21-1,134-136$ & 190.35 & 0.19 & 0.19 & -6.3 & -38.6 & - \\
\hline $21-2,62-64$ & 191.13 & 0.21 & 0.19 & 28.0 & -73.5 & $+1-$ \\
\hline $22-1,92-94$ & 199.43 & 0.091 & 0.20 & 43.0 & -3.5 & $+1-$ \\
\hline $22-2,13-15$ & 200.14 & 0.006 & 0.09 & -9.8 & -10.4 & - \\
\hline $23-1,82-84 *$ & 208.83 & 1.17 & 0.23 & -35.1 & -34.5 & - \\
\hline $23-2,68-70^{*}$ & 210.19 & 1.89 & 0.36 & -52.6 & -51.1 & - \\
\hline $23-3,103-105$ & 212.04 & 0.64 & 0.26 & 44.4 & 41.8 & + \\
\hline $24-1,22-24$ & 217.73 & 0.80 & 0.27 & -40.9 & -35.5 & - \\
\hline $24-2,16-18$ & 219.17 & 1.73 & 0.26 & 51.2 & 43.8 & + \\
\hline $24-3,57-59$ & 221.08 & 0.29 & 0.38 & 39.1 & -20.1 & $+1-$ \\
\hline $24-4,130-132$ & 223.31 & 0.63 & 0.34 & 42.9 & -18.2 & $+1-$ \\
\hline $24-5,29-31$ & 223.80 & 0.97 & 0.32 & 50.4 & -2.3 & $+1-$ \\
\hline $25-1,145-147$ & 228.46 & 1.65 & 0.31 & -42.0 & -33.7 & - \\
\hline $25-2,33-35^{*}$ & 228.09 & 4.19 & 0.38 & 36.8 & 35.7 & + \\
\hline $25-3,97-99^{*}$ & 230.98 & 2.11 & 0.31 & 31.9 & 30.1 & + \\
\hline $25-4,111-113$ & 228.87 & 0.14 & 0.42 & -30.5 & -40.3 & - \\
\hline
\end{tabular}

\begin{tabular}{|c|c|c|c|c|c|c|}
\hline \multirow{2}{*}{$\begin{array}{c}\text { Sample } \\
\text { (in terval in } \mathrm{cm} \text { ) }\end{array}$} & \multirow{2}{*}{$\begin{array}{l}\text { Sub- } \\
\text { bottom } \\
\text { Depth } \\
\text { (m) }\end{array}$} & \multirow{2}{*}{$\begin{array}{l}J_{\text {NRM }} \\
\text { (10-5 } \\
\text { gauss) }\end{array}$} & \multirow{2}{*}{$\begin{array}{c}\text { Suscepti- } \\
\text { bility } \\
\left(10^{-5}\right. \\
\text { gauss/oe })\end{array}$} & \multicolumn{2}{|c|}{ Inclination } & \multirow{2}{*}{$\begin{array}{c}\text { Polar } \\
\text { ity }\end{array}$} \\
\hline & & & & NRM & AFD & \\
\hline $445-25-5,127-129$ & 234.28 & 0.45 & 0.42 & -20.6 & -36.9 & - \\
\hline $25-6,59-61^{*}$ & 235.10 & 1.67 & 0.33 & -23.6 & -29.3 & - \\
\hline $26-1,139-141^{*}$ & 237.90 & 3.40 & 0.39 & 37.2 & 41.9 & + \\
\hline $26-2,140-142$ & 239.41 & 1.72 & 0.40 & 33.7 & 32.6 & + \\
\hline $26-3,144-146$ & 240.95 & 1.74 & 0.39 & 29.1 & 16.2 & + \\
\hline $26-4,145-147$ & 242.46 & 0.47 & 0.27 & -8.2 & -33.1 & - \\
\hline $26-5,140-142$ & 243.91 & 1.48 & 0.38 & 34.2 & 36.9 & + \\
\hline $26-5,60-62$ & 243.11 & 0.46 & 0.31 & 17.1 & 74.7 & + \\
\hline $27-1,81-83^{*}$ & 247.57 & 3.96 & 0.50 & 35.0 & 31.2 & + \\
\hline $27-2,59-61^{*}$ & 248.10 & 1.71 & 0.31 & -28.4 & -29.5 & - \\
\hline $27-3,54-56$ & 249.55 & 1.56 & 0.44 & 2.8 & -17.7 & $+1-$ \\
\hline $27-4,35-37$ & 250.86 & 1.40 & 0.48 & $\begin{array}{l}35.0 \\
35.7\end{array}$ & $\begin{array}{r}4.7 \\
34.2\end{array}$ & $\begin{array}{l}+ \\
+\end{array}$ \\
\hline $27-5,50-52 *$ & 252.51 & $\begin{array}{l}3.57 \\
0.48\end{array}$ & $\begin{array}{l}0.46 \\
0.19\end{array}$ & & & $+1-$ \\
\hline $\begin{array}{l}27-6,41-43 \\
28-1,128-130^{*}\end{array}$ & $\begin{array}{l}253.92 \\
256.79\end{array}$ & $\begin{array}{l}0.48 \\
2.34\end{array}$ & $\begin{array}{l}0.19 \\
0.33\end{array}$ & $\begin{array}{l}10.5 \\
36.0\end{array}$ & $\begin{array}{r}-52.4 \\
35.2\end{array}$ & + \\
\hline $28-2,106-108^{*}$ & 258.07 & 3.47 & 0.33 & 35.4 & 34.7 & + \\
\hline $28-3,147-149$ & 259.98 & 0.03 & 0.27 & 37.6 & 35.0 & + \\
\hline $28-4,100-102^{*}$ & 261.01 & 3.19 & 0.50 & 34.2 & 32.1 & + \\
\hline $28-5,118-120$ & 262.69 & 0.45 & 0.45 & -3.0 & -26.1 & - \\
\hline $29-1,44-46$ & 265.45 & 0.11 & 0.40 & -14.8 & -31.2 & - \\
\hline $29-2,60-62$ & 267.11 & 1.01 & 0.36 & 39.2 & 18.8 & + \\
\hline $29.3,55-57$ & 268.56 & 0.98 & 0.40 & 28.4 & 7.9 & + \\
\hline $29-4,8-10$ & 269.59 & 0.19 & 0.32 & 17.4 & -9.3 & $+1-$ \\
\hline $30-1,42-44^{*}$ & 274.93 & 2.13 & 0.43 & 38.0 & 31.2 & + \\
\hline $30-4,32-34$ & 279.33 & 0.01 & 0.29 & -57.3 & -53.7 & - \\
\hline $31-1,22-24$ & 284.23 & 1.98 & 0.44 & 37.3 & 31.9 & + \\
\hline $31-4,140-142$ & 289.91 & 0.02 & 0.29 & 26.4 & 14.1 & + \\
\hline $31-5,136-138^{*}$ & 291.37 & 3.52 & 0.39 & 28.4 & 28.3 & + \\
\hline $32-1,16-18$ & 293.67 & 2.07 & 0.34 & 27.7 & 10.2 & + \\
\hline $33-2,65-67$ & 305.16 & 0.15 & 0.33 & 9.2 & -4.5 & $+/-$ \\
\hline $33-3,18-20 *$ & 306.19 & 1.93 & 0.34 & -8.2 & -13.0 & - \\
\hline $33-5,61-63^{*}$ & 309.62 & 2.20 & 0.27 & 26.9 & 23.7 & + \\
\hline $34-2,37-39$ & 314.38 & 0.33 & 0.37 & 9.2 & -21.6 & $+1-$ \\
\hline $34-4,30-32$ & 317.31 & 0.22 & 0.38 & 8.9 & -39.1 & $+1-$ \\
\hline $34-5,24-26$ & 318.75 & 0.87 & 0.32 & -32.4 & -35.7 & - \\
\hline $35-1,12-14$ & 322.13 & 4.86 & 0.44 & 27.0 & 19.2 & + \\
\hline $35-2,78-80$ & 324.29 & 1.18 & 0.44 & 1.3 & -14.3 & $+1-$ \\
\hline $35-3,78-80$ & 325.79 & 0.64 & 0.27 & 35.3 & 3.9 & + \\
\hline $36-1,85-87$ & 332.36 & 1.41 & 0.47 & -9.7 & -30.1 & - \\
\hline $36-2,66-68$ & 333.67 & 1.43 & 0.48 & 36.5 & 35.2 & + \\
\hline $37-1,144-146$ & 342.45 & 0.75 & 0.36 & 62.2 & 6.7 & + \\
\hline $37-2,68-70$ & 343.19 & 1.09 & 0.42 & 31.4 & 33.7 & + \\
\hline $37-4,23-25$ & 345.74 & 0.012 & 0.71 & 38.2 & 21.3 & + \\
\hline $38-1,37-39$ & 350.88 & 0.56 & 0.40 & 46.0 & 8.3 & + \\
\hline $38-2,37-39$ & 352.38 & 0.26 & 0.40 & 74.2 & -5.1 & $+1-$ \\
\hline $38-3,39-41$ & 353.90 & 0.90 & 0.30 & 39.1 & 50.9 & + \\
\hline $38-4,39-41$ & 355.40 & 0.76 & 0.43 & 38.5 & 13.2 & + \\
\hline $38-5,70-72$ & 357.21 & 1.03 & 0.32 & 35.7 & 37.3 & + \\
\hline $39-1,94-96$ & 360.95 & 0.03 & 0.32 & 23.1 & -33.3 & $+1-$ \\
\hline $39-3,94-96$ & 363.95 & 0.91 & 0.28 & 27.4 & 35.7 & + \\
\hline $40-2,146-148$ & 372.47 & 0.001 & 0.32 & 50.8 & 49.8 & + \\
\hline $40-3,14-16$ & 372.65 & 1.17 & 0.44 & 34.5 & 38.2 & + \\
\hline $41-1,60-62$ & 379.61 & 0.83 & 0.37 & 25.6 & 33.8 & + \\
\hline $41-2,79-81$ & 381.30 & 0.68 & 1.81 & 27.0 & 28.1 & + \\
\hline $41-3,117-119$ & 380.93 & 0.00 & 0.31 & -18.7 & -27.4 & - \\
\hline $41-4,126-128^{*}$ & 384.77 & 1.62 & 0.36 & 34.6 & 28.5 & + \\
\hline $41-5,129-131$ & 386.30 & & 0.29 & 29.8 & 25.2 & + \\
\hline $41-6,33-35$ & 386.84 & 0.28 & 0.24 & 37.3 & 28.5 & + \\
\hline $42-1,98-100$ & 389.49 & 0.01 & 0.29 & 19.2 & 23.5 & + \\
\hline $42-3,44-46$ & 391.95 & 0.39 & 0.21 & -6.3 & -32.0 & + \\
\hline $42-4,104-106$ & 394.05 & 0.012 & 0.47 & 26.8 & 15.1 & + \\
\hline $42-5,75-77$ & 395.26 & 1.34 & 0.42 & 55.7 & & + \\
\hline $42-6,22-24$ & 396.23 & 0.43 & 0.27 & -10.0 & -14.4 & - \\
\hline $43-1,23-25$ & 398.24 & 0.28 & 0.40 & 39.9 & 35.7 & + \\
\hline $43-2,100-102$ & 400.49 & 0.35 & 0.32 & 37.4 & 42.7 & + \\
\hline $43-3,66-68$ & 401.67 & 0.74 & 0.34 & 15.5 & & + \\
\hline $44-1,90-92$ & 408.41 & 0.78 & 0.34 & 43.0 & 42.2 & + \\
\hline $44-2,63-65$ & 408.89 & 1.54 & 0.52 & 35.6 & 21.6 & + \\
\hline $44-3,130-132$ & 411.79 & 1.72 & 0.43 & 18.7 & 11.0 & + \\
\hline $44-4,05-07$ & 412.06 & 0.76 & 0.39 & 26.9 & 26.9 & + \\
\hline
\end{tabular}


TABLE 5 - Continued

\begin{tabular}{|c|c|c|c|c|c|c|}
\hline \multirow{2}{*}{$\begin{array}{c}\text { Sample } \\
\text { (interval in } \mathrm{cm} \text { ) }\end{array}$} & \multirow{2}{*}{$\begin{array}{l}\text { Sub- } \\
\text { bottom } \\
\text { Depth } \\
\text { (m) }\end{array}$} & \multirow{2}{*}{$\begin{array}{c}J_{\mathrm{NRM}} \\
\left(10^{-5}\right. \\
\text { gauss) }\end{array}$} & \multirow{2}{*}{$\begin{array}{c}\text { Suscepti- } \\
\text { bility } \\
\left(10^{-5}\right. \\
\text { gauss/oe) }\end{array}$} & \multicolumn{2}{|c|}{ Inclination } & \multirow{2}{*}{$\begin{array}{l}\text { Polar- } \\
\text { ity }\end{array}$} \\
\hline & & & & NRM & AFD & \\
\hline $445-45-1,13-15$ & 417.14 & 0.79 & 0.32 & -4.7 & -20.9 & + \\
\hline $45-2,73-75$ & 419.24 & 0.38 & 0.31 & -11.0 & -20.8 & - \\
\hline $45-3,31-33$ & 420.32 & 0.73 & 0.37 & 3.0 & -15.2 & $+1-$ \\
\hline $45-4,06-08$ & 421.57 & 0.93 & 0.40 & 55.6 & 53.4 & \\
\hline $45-5,66-68$ & 423.67 & 1.31 & 0.45 & -12.0 & -19.5 & - \\
\hline $46-1,28-30^{*}$ & 426.79 & 1.73 & 0.28 & 34.8 & 35.3 & + \\
\hline $46-2,28-30^{*}$ & 428.29 & 2.85 & 0.44 & 24.2 & 23.6 & + \\
\hline $46-3,28-30^{*}$ & 429.79 & 3.38 & 0.56 & 23.6 & 21.2 & + \\
\hline $46-4,28-30 *$ & 431.29 & 6.52 & 0.57 & 30.0 & 29.3 & + \\
\hline $46-5,28-30$ & 432.79 & 2.13 & 0.58 & -80.4 & -77.3 & - \\
\hline $46-6,28-30^{*}$ & 434.29 & 10.7 & 1.25 & -2.9 & -7.6 & - \\
\hline $47-1,73-75^{*}$ & 436.74 & 2.82 & 0.53 & -19.1 & -22.0 & - \\
\hline $47-2,73-75^{*}$ & 438.24 & 5.46 & 0.81 & -18.2 & -21.5 & - \\
\hline $47-3,73-75^{*}$ & 439.74 & 2.41 & 0.47 & 34.8 & 28.5 & + \\
\hline $47-4,73-75^{*}$ & 441.24 & 3.96 & 0.47 & 29.4 & 28.4 & + \\
\hline $47-5,73-75^{*}$ & 442.74 & 8.88 & 0.73 & 28.3 & 28.3 & + \\
\hline $47-6,73-75^{*}$ & 444.24 & 5.33 & 0.45 & 12.9 & 7.7 & + \\
\hline $48-1,26-28 *$ & 445.77 & 3.55 & 0.44 & 22.8 & 20.9 & + \\
\hline $48-2,26-28$ & 447.27 & 1.93 & 0.40 & 7.4 & 1.5 & + \\
\hline $48-3,26-28^{*}$ & 448.77 & 3.52 & 0.52 & 24.2 & 23.2 & + \\
\hline $48-4,26-28$ & 450.27 & 1.91 & 0.36 & 29.7 & 20.1 & + \\
\hline $49-1, ?$ & $455.75+?$ & 1.77 & 0.40 & 35.5 & 30.6 & + \\
\hline $49-2,54-56^{*}$ & 457.05 & 5.34 & 0.40 & 27.0 & 26.3 & + \\
\hline $49-3,54-56$ & 458.55 & 1.85 & 0.52 & 26.7 & 18.8 & + \\
\hline $49-4,54-56^{*}$ & 460.05 & 4.56 & 0.45 & 25.4 & 26.1 & + \\
\hline $49-5,54-56$ & 461.55 & 1.68 & 0.44 & 27.9 & 22.9 & + \\
\hline $50-1,38-40$ & 464.89 & 1.95 & 0.49 & 22.2 & 15.8 & + \\
\hline $50-2,38-40$ & 466.39 & 1.55 & 0.40 & -26.6 & -30.9 & - \\
\hline $51-1,77-79$ & 474.78 & 4.03 & 0.98 & 44.2 & 41.3 & + \\
\hline $51-3,108-110$ & 478.09 & 0.16 & 0.44 & 11.8 & -1.0 & $+1-$ \\
\hline $52-2,86-88$ & 485.87 & 2.33 & 0.42 & 5.2 & -3.0 & $+1-$ \\
\hline $52-4,64-66$ & 488.65 & 1.77 & 0.69 & 20.2 & 12.9 & + \\
\hline $53-1,37-39$ & 493.38 & 0.84 & 0.61 & 14.9 & 0.8 & + \\
\hline $53-2,37-39$ & 494.89 & 1.12 & 0.46 & 38.0 & 34.6 & + \\
\hline $53-3,37-39$ & 496.38 & 1.63 & 0.52 & 40.7 & 38.3 & + \\
\hline $53-5,23-25$ & 499.24 & 3.38 & 1.21 & 38.2 & 39.7 & + \\
\hline $53-5,37-39 *$ & 499.38 & 2.30 & 0.50 & -14.9 & -19.6 & - \\
\hline $541,38-40^{*}$ & 502.89 & 4.22 & 0.69 & -5.0 & -10.6 & - \\
\hline $54-2,38-40^{*}$ & 504.39 & 2.43 & 0.39 & 32.3 & 30.0 & + \\
\hline $54-3,38-40^{*}$ & 505.89 & 3.67 & 0.54 & 4.4 & -1.3 & $+1-$ \\
\hline $54-4,38-40$ & 507.39 & 1.91 & 0.55 & -16.8 & -29.7 & - \\
\hline $54-5,38-40$ & 508.89 & 0.71 & 0.51 & 24.5 & 3.2 & + \\
\hline $54-6,38-40$ & 510.39 & 0.16 & 0.38 & 36.2 & 14.7 & + \\
\hline $55-1,38-40$ & 512.39 & 1.18 & 0.55 & 11.5 & 16.2 & + \\
\hline $55-2,38-40$ & 513.89 & 1.71 & 0.54 & -7.6 & -15.5 & - \\
\hline $55-3,38-40$ & 515.39 & 0.04 & 0.35 & 64.0 & -18.2 & $+1-$ \\
\hline $55-4,38-40$ & 516.85 & 2.96 & 1.08 & 18.5 & -0.6 & $+1-$ \\
\hline $55-5,43-45^{*}$ & 518.44 & 5.60 & 0.54 & -14.9 & -18.2 & - \\
\hline $55-6,43-45$ & 519.94 & 0.69 & 0.68 & 24.4 & -7.5 & $+1-$ \\
\hline $56-1,33-35^{*}$ & 521.84 & 3.31 & 0.57 & -8.5 & -13.5 & - \\
\hline $56-2,33-35^{*}$ & 523.34 & 8.58 & 1.21 & -14.3 & -18.7 & - \\
\hline $56-3,33-35^{*}$ & 524.84 & 6.49 & 0.88 & -19.4 & -22.0 & - \\
\hline $56-4,33-35^{*}$ & 526.34 & 5.28 & 1.00 & -8.5 & -14.4 & - \\
\hline $56-5,33-35$ & 527.84 & 1.25 & 0.74 & -2.1 & -19.9 & - \\
\hline $57-1,73-75$ & 531.74 & 0.64 & 0.31 & 4.1 & 3.7 & + \\
\hline $57-2,74-76^{*}$ & 533.27 & 2.10 & 0.48 & 34.0 & 33.7 & + \\
\hline $57-3,73-75^{*}$ & 534.74 & 6.48 & 0.64 & 25.1 & 24.2 & + \\
\hline $57-4,74-76$ & 536.25 & 2.07 & 0.54 & 29.4 & 25.5 & + \\
\hline $57-5,73-75$ & 537.74 & 1.16 & 0.32 & 23.0 & 17.9 & + \\
\hline $58-1,103-105$ & 541.54 & 2.17 & 0.52 & 31.7 & 33.0 & + \\
\hline $58-2,23-25^{*}$ & 542.24 & 1.91 & 0.45 & 29.7 & 33.8 & + \\
\hline $58-3,110-112$ & 544.61 & 0.92 & 0.35 & -4.1 & -10.6 & - \\
\hline $58-4,146-148$ & 546.47 & 1.28 & 0.48 & -7.5 & -11.9 & - \\
\hline $58-5,93-95$ & 547.44 & 1.61 & 0.55 & -12.3 & -18.2 & - \\
\hline $59-1,72-74$ & 550.73 & 2.02 & 0.55 & 2.6 & -3.2 & $+1-$ \\
\hline $59-2,83-85$ & 552.34 & 2.89 & 0.51 & 10.4 & 2.7 & + \\
\hline $59-3,26-28 *$ & 553.27 & 9.06 & 0.68 & -25.9 & -27.8 & - \\
\hline $59-4,145-147^{*}$ & 555.96 & 6.50 & 0.71 & -12.1 & -14.9 & - \\
\hline $59-5,06=08^{*}$ & 556.07 & 6.35 & 0.61 & -4.1 & -8.4 & - \\
\hline $59-6,28-30 *$ & 557.79 & 10.88 & 1.00 & 17.6 & 17.0 & + \\
\hline
\end{tabular}

TABLE 5 - Continued

\begin{tabular}{|c|c|c|c|c|c|c|}
\hline \multirow{2}{*}{$\begin{array}{c}\text { Sample } \\
\text { (interval in cm) }\end{array}$} & \multirow{2}{*}{$\begin{array}{c}\text { Sub- } \\
\text { bottom } \\
\text { Depth } \\
\text { (m) }\end{array}$} & \multirow{2}{*}{$\begin{array}{c}J_{\text {NRM }} \\
\left(10^{-5}\right. \\
\text { gauss) }\end{array}$} & \multirow{2}{*}{$\begin{array}{c}\text { Suscepti- } \\
\text { bility } \\
\left(10^{-5}\right. \\
\text { gauss/oe })\end{array}$} & \multicolumn{2}{|c|}{ Inclination } & \multirow{2}{*}{$\begin{array}{l}\text { Polar- } \\
\text { ity }\end{array}$} \\
\hline & & & & NRM & AFD & \\
\hline $445-60-1,41-43$ & 559.92 & 0.05 & 0.78 & -15.0 & -18.2 & - \\
\hline $60-2,127-129$ & 562.29 & 0.57 & 0.64 & 15.8 & 2.5 & + \\
\hline $60-3,49-51^{*}$ & 563.00 & 5.07 & 0.87 & 4.6 & 1.4 & + \\
\hline $60-4,13-15$ & 564.14 & 2.22 & 0.81 & 24.5 & 13.9 & + \\
\hline $61-1,40-42 *$ & 569.41 & 5.70 & 0.95 & -14.6 & -15.4 & - \\
\hline $61-2,109-111 *$ & 571.58 & 8.17 & 0.81 & 16.9 & 16.7 & + \\
\hline $61-3,76-78^{*}$ & 572.77 & 10.94 & 0.93 & 20.1 & 20.1 & + \\
\hline $61-4,140-142 *$ & 574.91 & 6.97 & 0.83 & 19.3 & 19.1 & + \\
\hline $61-5,136-138^{*}$ & 576.37 & 5.14 & 0.65 & 20.1 & 17.8 & + \\
\hline $61-6,34-36^{*}$ & 576.85 & 7.84 & 0.87 & 22.4 & 22.0 & + \\
\hline $61-7,37-39$ & 578.38 & 1.87 & 0.81 & -2.1 & -12.5 & - \\
\hline $62-1,143-145$ & 579.94 & 1.70 & 0.65 & 9.7 & -1.5 & $+1-$ \\
\hline $62-2,44-46$ & 580.45 & 0.88 & 0.56 & 0.4 & -10.9 & $+1-$ \\
\hline $62-3,143-145$ & 582.94 & 2.76 & 0.75 & 29.6 & 26.8 & + \\
\hline $62-4,130-132^{*}$ & 584.31 & 7.43 & 1.16 & 29.4 & 29.5 & + \\
\hline $62-5,130-132 *$ & 585.81 & 5.29 & 0.84 & 22.8 & 20.8 & + \\
\hline $62-6,63-65 *$ & 586.64 & 9.58 & 0.19 & 31.4 & 31.9 & + \\
\hline $63-1,22-24$ & 588.23 & 0.53 & 0.56 & 59.9 & 63.6 & + \\
\hline $63-2,127-129$ & 590.78 & 3.29 & 0.74 & 33.7 & 32.0 & + \\
\hline $63-3,22-24$ & 591.23 & 1.70 & 0.59 & 26.7 & 27.2 & + \\
\hline $63-4,116-118$ & 593.67 & 1.14 & 0.55 & 22.0 & 17.9 & + \\
\hline $64-1,04-06$ & 597.55 & 3.11 & 0.81 & 21.5 & 19.0 & + \\
\hline $64-2,18-20$ & 599.19 & 1.68 & 0.52 & -1.1 & -3.9 & - \\
\hline $64-3,18-20$ & 600.69 & 1.40 & 0.57 & 19.4 & 17.2 & + \\
\hline $64-4,18-20^{*}$ & 602.19 & 4.39 & 0.64 & 18.2 & 14.5 & + \\
\hline $64-5,18-20^{*}$ & 603.69 & 3.81 & 0.64 & 16.4 & 14.7 & + \\
\hline $64-6,05-07 *$ & 605.06 & 3.84 & 0.68 & 12.3 & 13.4 & + \\
\hline $64-7,05-07$ & 606.56 & 3.16 & 0.78 & 17.2 & 14.9 & + \\
\hline $65-1,42-44$ & 607.43 & 2.18 & 0.69 & 19.7 & 18.4 & + \\
\hline $65-2,42-44$ & 608.93 & 0.88 & 0.61 & 34.3 & - & $(+)$ \\
\hline $65-3,42-44$ & 610.43 & 2.46 & 0.73 & 15.4 & 12.4 & + \\
\hline $66-1,16-18^{*}$ & 616.67 & 5.85 & 0.65 & -13.5 & -15.6 & - \\
\hline $66-2,16-18^{*}$ & 618.17 & 5.69 & 0.81 & -1.0 & -3.4 & - \\
\hline $66-3,16-18$ & 619.67 & 3.16 & 0.88 & 11.0 & 3.6 & + \\
\hline $66-4,16-18^{*}$ & 621.17 & 3.95 & 0.55 & -9.6 & -11.5 & - \\
\hline $66-5,16-18$ & 622.67 & 2.34 & 0.55 & 13.5 & 8.6 & + \\
\hline $67-1,19-21^{*}$ & 626.20 & 7.08 & 0.81 & 16.3 & 15.5 & + \\
\hline $68-1,78-80$ & 636.29 & 2.39 & 2.05 & 19.5 & 24.0 & + \\
\hline $68-2,41-43$ & 637.42 & 1.12 & 1.41 & 31.7 & 22.6 & + \\
\hline $69-1,24-26$ & 645.25 & 1.55 & 0.78 & 2.9 & 2.8 & + \\
\hline $69-2,100-102^{*}$ & 647.51 & 18.99 & 2.47 & -1.4 & -1.7 & - \\
\hline $69-4,52-54$ & 650.03 & 4.24 & 0.43 & 0.1 & -4.2 & $+1-$ \\
\hline $70-2,07-09 *$ & 656.08 & 27.65 & 1.60 & 7.0 & 6.6 & \\
\hline $71-1,38-40$ & 664.39 & 3.84 & 1.31 & -18.5 & -16.5 & \\
\hline $71-2,06-08$ & 665.57 & 14.34 & 2.46 & 6.4 & 7.6 & \\
\hline $71-3,38-40^{*}$ & 667.39 & 15.55 & 2.29 & 6.0 & 4.9 & \\
\hline $71-4,13-15$ & 668.64 & 11.65 & 3.37 & -36.2 & -38.4 & \\
\hline $72-1,43-45$ & 673.94 & 14.65 & 3.10 & 2.5 & 2.3 & \\
\hline $72-2,43-45$ & 675.44 & 4.12 & 3.46 & -33.2 & -36.3 & \\
\hline $73-1,84-86$ & 683.85 & 11.09 & 6.53 & -2.7 & 16.0 & \\
\hline $73-2,84-86$ & 685.35 & 11.77 & 5.13 & 16.0 & 18.4 & \\
\hline $73-3,84-86$ & 686.85 & 4.32 & 6.12 & 9.2 & 34.1 & \\
\hline $74-2,46-48^{*}$ & 694.47 & 28.93 & 2.42 & 7.5 & 6.8 & \\
\hline $74-4,46-48^{*}$ & 697.47 & 19.11 & 2.68 & 5.0 & 4.8 & \\
\hline $74-5,46-48^{*}$ & 698.97 & 18.77 & 2.66 & 9.3 & 10.9 & \\
\hline $75-1,39-41^{*}$ & 702.40 & 30.88 & 2.26 & -10.1 & -11.8 & \\
\hline $75-2,39-41^{*}$ & 703.90 & 13.40 & 2.32 & -2.8 & -2.0 & \\
\hline $75-3,120-122$ & 706.21 & 4.73 & 1.71 & 42.6 & 22.3 & \\
\hline $75-4,43-45$ & 706.94 & 2.60 & 1.73 & 31.9 & $\overline{2}$ & \\
\hline $75-5,43-45$ & 708.44 & 2.66 & 3.20 & 25.0 & 27.8 & \\
\hline $76-1,87-89^{*}$ & 712.38 & 19.52 & 2.49 & 11.6 & 8.1 & \\
\hline $76-3,106-108^{*}$ & 715.57 & 20.42 & 2.78 & 3.9 & 2.7 & \\
\hline $76-4,109-111^{*}$ & 717.10 & 32.21 & 2.20 & 17.9 & 17.7 & \\
\hline $76-5,20-22$ & 717.71 & 13.40 & 3.46 & -12.6 & -15.0 & \\
\hline $77-1,139-141$ & 722.40 & 14.05 & 3.13 & -7.7 & -3.0 & \\
\hline $77-2,38-40^{*}$ & 722.89 & 24.10 & 4.02 & 5.8 & 4.1 & \\
\hline $77-3,139-141$ & 725.40 & 6.04 & 2.84 & 44.5 & 37.5 & \\
\hline $77-4,144-146$ & 726.95 & 32.84 & 2.77 & -0.1 & -2.6 & \\
\hline $77-5,92-94$ & 727.93 & 21.89 & 2.83 & -24.5 & -18.8 & \\
\hline $78-1,84-86$ & 731.35 & 14.41 & 2.65 & 2.4 & -2.1 & \\
\hline
\end{tabular}


TABLE 5 - Continued

\begin{tabular}{|c|c|c|c|c|c|c|}
\hline \multirow{2}{*}{$\begin{array}{c}\text { Sample } \\
\text { (interval in cm) }\end{array}$} & \multirow{2}{*}{$\begin{array}{l}\text { Sub- } \\
\text { bottom } \\
\text { Depth } \\
\text { (m) }\end{array}$} & \multirow{2}{*}{$\begin{array}{l}J_{\mathrm{NRM}} \\
\left(10^{-5}\right. \\
\text { gauss })\end{array}$} & \multirow{2}{*}{$\begin{array}{c}\text { Suscepti- } \\
\text { bility } \\
\left(10^{-5}\right. \\
\text { gauss/oe })\end{array}$} & \multicolumn{2}{|c|}{ Inclination } & \multirow{2}{*}{$\begin{array}{l}\text { Polar- } \\
\text { ity }\end{array}$} \\
\hline & & & & NRM & AFD & \\
\hline $445-78-2,60-62 *$ & 732.61 & 26.23 & 2.69 & 5.5 & 3.8 & \\
\hline $78-3,20-22 *$ & 733.71 & 24.49 & 2.99 & 3.5 & 0.9 & \\
\hline $78-4,25-27^{*}$ & 735.26 & 25.55 & 2.39 & -5.3 & -6.3 & \\
\hline $78-5,112-114$ & 737.63 & 7.84 & 3.54 & -33.8 & -23.9 & \\
\hline $79-2,130-132 *$ & 742.81 & 23.43 & 1.81 & 3.2 & 1.4 & \\
\hline $79-3,52-54$ & 743.53 & 19.26 & 3.07 & -13.0 & -1.6 & \\
\hline $79-4,54-56 *$ & 745.05 & 27.00 & 2.81 & -3.4 & -6.0 & \\
\hline $79-5,51-53^{*}$ & 746.52 & 25.49 & 3.39 & -25.4 & -27.2 & \\
\hline $80-1,135-137$ & 750.86 & 13.14 & 3.70 & -8.9 & -13.7 & \\
\hline $80-2,138-140$ & 752.39 & 15.38 & 4.45 & -9.8 & -13.4 & \\
\hline $80-3,138-140$ & 753.89 & 16.10 & 4.19 & -10.5 & -10.1 & \\
\hline $80-5,140-142$ & 756.89 & 4.23 & 5.76 & 6.3 & - & \\
\hline $81-1,56-58$ & 759.57 & 28.79 & 4.12 & -18.7 & -20.6 & \\
\hline $81-3,56-58$ & 762.57 & 20.12 & 4.29 & 28.8 & -16.6 & \\
\hline $81-5,56-58$ & 765.58 & 11.79 & 5.10 & -1.9 & - & \\
\hline $82-1,70-72$ & 769.19 & 19.59 & 4.97 & -21.9 & - & \\
\hline $82-3,70-72$ & 772.21 & 7.48 & 6.23 & -26.6 & - & \\
\hline $83-1,76-78$ & 778.77 & 23.01 & 4.94 & -2.9 & -4.4 & \\
\hline $83-3,76-78$ & 781.77 & 10.87 & 6.52 & 48.4 & - & \\
\hline $83-5,76-78$ & 784.77 & 9.93 & 4.67 & -24.6 & - & \\
\hline $84-1,100-102$ & 788.51 & 17.09 & 4.37 & 9.8 & - & \\
\hline $84-3,100-102$ & 791.51 & 18.38 & 4.59 & 3.3 & - & \\
\hline $85-3,97-99$ & 800.98 & 7.44 & 4.41 & -31.1 & - & \\
\hline $85-4,94-96^{*}$ & 802.45 & 32.57 & 5.52 & 10.3 & 11.9 & \\
\hline $86-2,56-58$ & 808.57 & 7.99 & 2.61 & 11.1 & - & \\
\hline $86-4,56-58$ & 811.57 & 14.17 & 5.97 & 13.8 & - & \\
\hline $87-4,40-42$ & 820.91 & 7.03 & 4.86 & 19.9 & - & \\
\hline $87-6,40-42$ & 823.91 & 17.48 & 3.68 & 59.1 & - & \\
\hline $88-3,58-60$ & 829.09 & 13.37 & 3.46 & 18.5 & - & \\
\hline $88-4,58-60$ & 830.59 & 14.83 & 3.67 & 8.6 & - & \\
\hline $89-4,89-91$ & 840.40 & 9.89 & 4.60 & 23.6 & - & \\
\hline $89-6,64-66^{*}$ & 843.15 & 43.88 & 2.59 & 14.1 & 12.7 & \\
\hline
\end{tabular}

${ }^{\mathrm{a}} J_{\mathrm{NRM}}$ is the intensity of NRM given in $10^{-5}$ gauss $/ \mathrm{cm}^{3}$; AFD is obtained by peak alternating demagnetizing field of 150 oe, decreasing to zero at a constant rate of 20 milligauss/cycle; polarity shows whether the in clination of NRM is positive $(+)$ or negative $(-)$; an asterisk at the sample number denotes good reliability for the sample.

highly stable and strong NRM similar to this mudstone (for example, lapilli tuff at Oshima, Japan, and welded tuff of Aso volcano, Kyushu, Japan).

In addition a fine, continuous record of polarity reversal was found. Between 142 and 551 meters, the sedimentary cores consist mainly of milky-colored nannofossil chalk. This part of the sediment was consolidated and was easily drilled, with a lesser number of fractures within each 9-meter core. Routine measurement in minicores every 1.5 meters showed that between Cores 45 and 47 there are more than two reversals. It is interesting to note that these cores cover only about $1 \mathrm{~m} . \mathrm{y}$. (24-25 Ma).

After rechecking the magnetic stability of NRM, it appears that the reversal would not have taken place due to a secondary effect, but must have recorded a real reversal of the geomagnetic field (at least the direction of a local magnetic field).

\section{PHYSICAL PROPERTIES}

Site 445 sediments and sedimentary rocks vary considerably in composition, texture, porosity, and water content. This variability is directly reflected in physical properties (Table 7).
Figure 15 shows the variation of sonic velocity and wet-bulk density with depth for Hole 445 . Velocities range from about 1.5 to $1.6 \mathrm{~km} / \mathrm{s}$ in sub-units $\mathrm{Ia}, \mathrm{Ib}$, and IIa, and systematically increase from 1.7 to 2.6 $\mathrm{km} / \mathrm{s}$ within sub-units IIb and IIc. Velocities decrease near the base of sub-unit IIc, and generally continue to decrease through units IId and III. This decrease may be related to the decrease of calcium carbonate relative to silica in unit III. Unit IV is characterized by high and relatively variable sonic velocities. This is caused by the interlayering of various lithologies, including chert, radiolarite, mudstone, and conglomerate. The mudstones of unit $\mathrm{V}$ show monotonous velocities somewhat above $2 \mathrm{~km} / \mathrm{s}$ and lower than those of the overlying unit. Velocities again increase in the conglomerates and sandstones of unit VI. Wet-bulk density follows the same pattern with respect to depth as sonic velocity (Figure $15)$.

There are several features of note in the velocitydepth profile presented in Figure 15. First, a clear velocity gradient distinguishes the upper 450 meters of the velocity column. Velocity gradients such as this will not necessarily be evident in marine reflection and refraction data and, if present, will tend to cause overestimation of layer thickness. Second, there are two distinctive low-velocity layers within the sediment column at Site 445. One occurs between the base of unit IIc and the top of unit IV. Unit V comprises the second velocity inversion. The presence of low-velocity layers will also lead to miscalculation of layer thicknesses using marine seismic data.

The variation of thermal conductivity with depth (Figure 16) is the same as the variations of sonic velocity and wet-bulk density (Figure 15). Conductivity increases with depth in units I, IIa, IIb, and IIc. This trend is similar to that observed by Hyndman et al. (1974) for Leg 26 sediments. The increase in conductivity with depth is directly related to the decreasing water content of the nannofossil oozes and chalks. This inverse relationship is shown in Figure 17 for sediments in Cores 1 through 58 . The decrease of conductivity with increasing water content conforms to the general relationship established by Ratcliffe (1960). Site 445 data for carbonates, however, plot consistently above Ratcliffe's empirically determined curve (Figure 17).

Conductivity values decrease from a maximum in sub-unit IIc to a minimum in unit III. The decrease reflects the down-hole decrease in the amount of calcite, a mineral with a high thermal conductivity. Conductivities increase to an average of $3.2 \mathrm{mcal} / \mathrm{cm}-{ }^{\circ} \mathrm{C}$-s below unit III, and remain nearly constant for the mudstones, sandstones, and conglomerates of the lower portion of the recovered sedimentary section.

In general, conductivities for Site 445 sediments are higher than those reported for the clay-dominated lithologies of Sites 442,443 , and 444 . This difference is caused by the generally higher thermal conductivity of the calcite-bearing lithologies of Site 445 and the generally lower water content of the carbonates. Bimodal distributions of thermal conductivities for oceanic sedi- 
Normal $\square$ Reversed $\quad$ Not Sampled or No Recovery

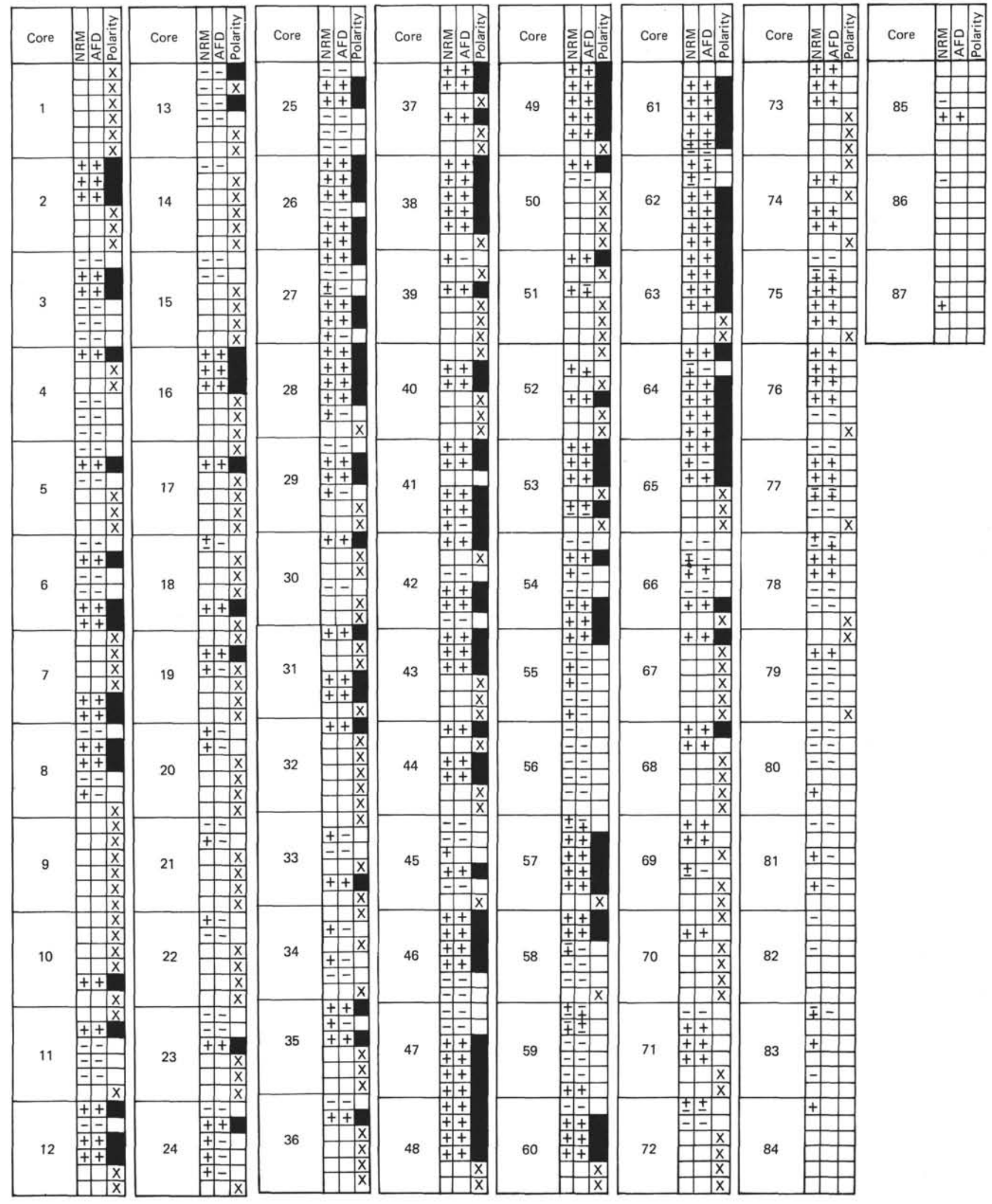

Figure 12. Results listed in Table 5 illustrated in descending order of cores and sections. Lowermost part of the polarity column is left blank because of poor resolution of NRM inclinations (see text). 

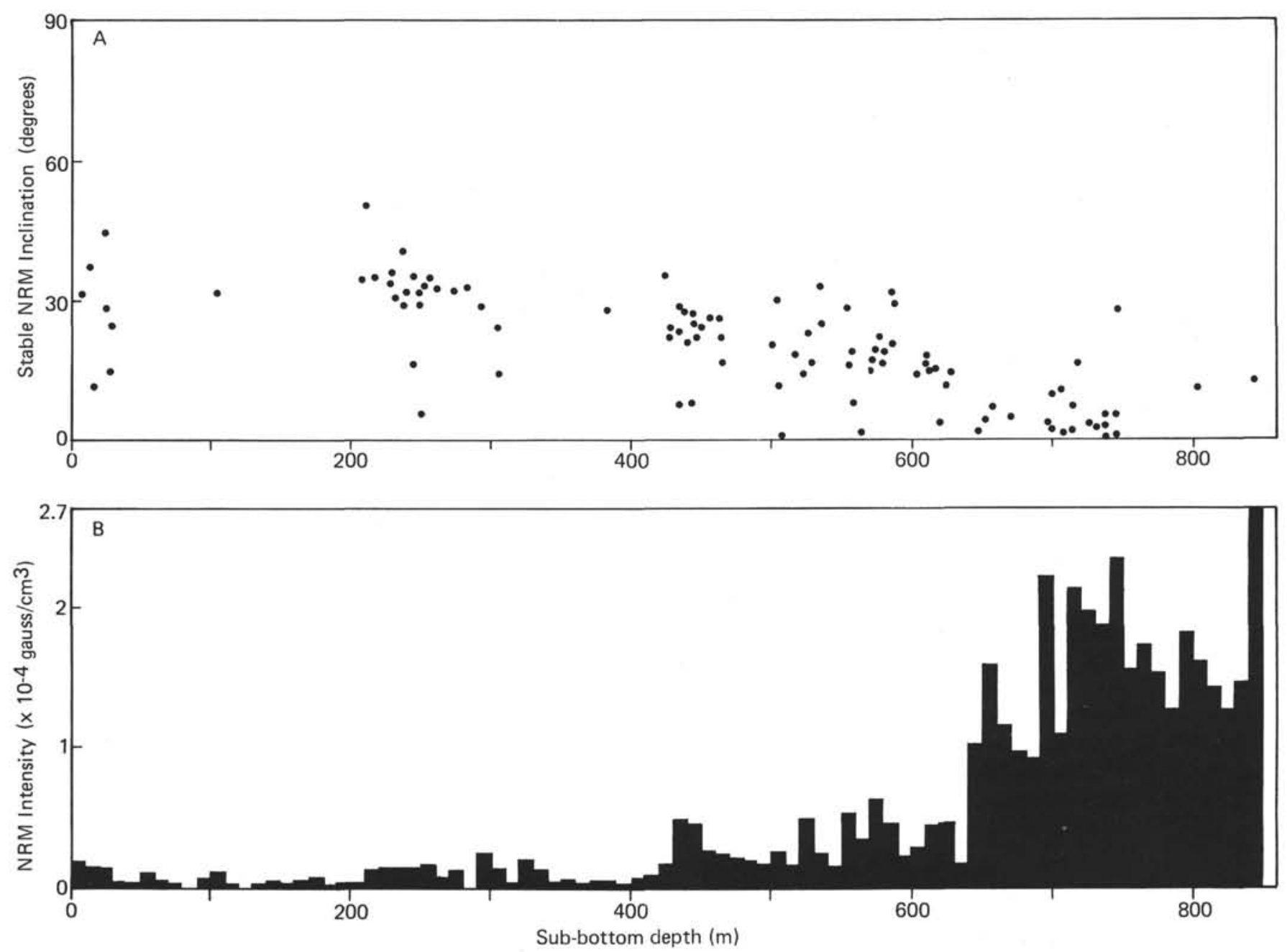

Figure 13. Paleomagnetism parameters plotted against sub-bottom depth. A. Absolute value of inclination of stable NRM of sediments. B. NRM intensity values averaged for every 10 meters.

TABLE 6

Statistical Treatment of Absolute Values of NRM Inclination ${ }^{a}$

\begin{tabular}{lcccc}
\hline $\begin{array}{l}\text { Sub-bottom Depth } \\
(\mathrm{m})\end{array}$ & $0-200$ & $200-400$ & $400-600$ & 600 \\
\hline $\begin{array}{l}\text { Number of } \\
\text { Reliable Samples }\end{array}$ & 9 & 18 & 41 & 27 \\
$\begin{array}{l}\text { Mean Inclination } \\
\text { (degrees) }\end{array}$ & 34.3 & 32.1 & 20.8 & $8.9(?)^{\mathrm{b}}$ \\
$\begin{array}{l}\text { Standard Deviation } \\
\begin{array}{l}\text { Expected Latitude } \\
\text { (degrees) }\end{array}\end{array}$ & 21.2 & 7.6 & 8.3 & 6.3 \\
\hline
\end{tabular}

aExpected latitude values are deduced from the mean of NRM inclinations. bPoor resolution power of inclination at lower latitude.

ments (e.g., Erickson, 1973; Marshall and Erickson, 1974; Hyndman et al., 1974) apparently are created by these fundamental differences between lithologies dominated by clay minerals and carbonate minerals.

Shear strength ranges from 0.0 to 3.0 dynes $/ \mathrm{cm}^{2}$; two measurements exceed this range. The nearly constant shear strength below 40 meters (Figure 18 ) reflects the constant lithology of the nannofossil ooze. Because of the lithologic differences between Site 445 and Sites 442 , 443 , and 444 , the previously reported variations of shear strength with depth are not in evidence at Site 445.

\section{CORRELATION OF GEOPHYSICAL DATA WITH DRILLING RESULTS}

Site 445 is 1 nautical mile northwest of shot point 3960 of line 3-2, multichannel seismic reflection profile of S/V Kaiyo-Maru (Figure 19). The uppermost layer, with a two-way normal time thickness of 0.4 seconds, is semi-transparent, and the underlying 0.3 -second section is moderately stratified. Below this, two discrete, sharp reflectors can be observed at 0.68 seconds and $0.72 \mathrm{sec}-$ onds, respectively.

Lithology and sonic velocity of the recovered cores can be correlated with these acoustic reflectors as follows:

1. The uppermost, semi-transparent layer corresponds to nannofossil ooze and the upper portion of nannofossil chalk sections lying above a sub-bottom depth of 360 meters, at which sonic velocity increases from 1.6 to $1.8 \mathrm{~km} / \mathrm{s}$ to $2.0 \mathrm{~km} / \mathrm{s}$. 


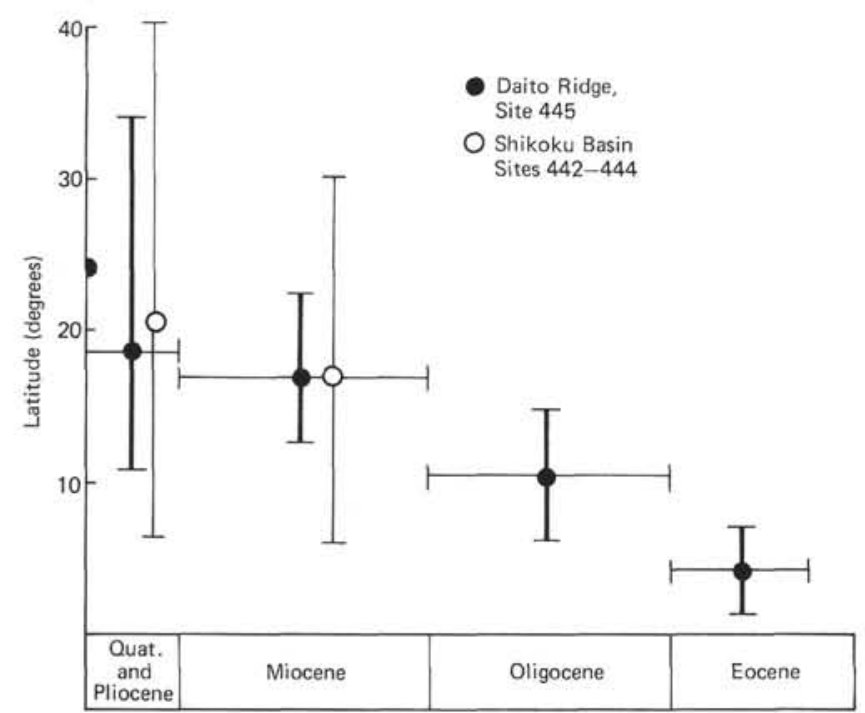

Figure 14. Latitude of Site 445 in the geological past. Solid circles are calculated and plotted from mean values of the absolute NRM inclination, as listed in Table 6. Horizontal bars show time spans for which inclination values are averaged. Vertical bars show probable errors corresponding to the standard deviations of NRM inclination in Table 6, asymmetrical around the expected geographic latitude. Open circles are plots for Sites 442 through 444 (mixed), for comparison. A solid semicircle on the left of the figure indicates the present latitude.

2. There are a few levels at which the sonic velocity sharply increases and then gradually decreases downhole; this is possibly associated with increase in clay content in chalk. The stratified structure of the lower sediment sections seen in the acoustic record is due to such a repetition of composition in chalk downhole.

3. Occurrence of chert and radiolarite, which show high sonic velocity of $3.0 \mathrm{~km} / \mathrm{s}$, is indicated by the sharp reflector observed at 0.68 seconds.

4. Conglomerate occurring at the hole bottom shows sonic velocity higher than $3.0 \mathrm{~km} / \mathrm{s}$. The boundary between the conglomerate and the overlying mudstone $\left(V_{P}\right.$ $=2.1$ ) probably marks the discrete reflector at $0.72 \mathrm{sec}-$ onds.

5. Lithified basement is not clearly recognized in the seismic profile. An indistinct reflector at 0.91 seconds is likely the basement. If the average velocity of the overlying layers is assumed to be $2.1 \mathrm{~km} / \mathrm{s}$, the sub-bottom depth of basement is 956 meters below the mudline.

Sonobuoy site-survey measurements show that a 310-meter-thick layer $\left(V_{P}=1.85\right)$ overlies a 240 -meterthick layer $\left(V_{P}=2.11\right)$ and a 890 -meter-thick layer $\left(V_{P}\right.$ $=3.9$ ), underlain by the basement with $V_{P}=5.7$. Thickness and sonic velocity of the upper two layers are roughly consistent with those of the recovered cores. Sonic velocity of the underlying layer, in contrast, seems to be overestimated; thus thickness of the layer is likewise overestimated. If the interval velocity is assumed to be $2.5 \mathrm{~km} / \mathrm{s}$, the layer apparently becomes as thin as 580 meters, consistent with the depth of basement estimated by other methods. Sonobuoy data may be less precise here because of rough basement topography.

\section{SUMMARY AND CONCLUSIONS}

\section{Summary}

The stratigraphic section at Site 445 consists of six sedimentary units. Some of these units have been subdivided further on the basis of biogenic content, color, and minor compositional changes.

The total penetration at Site 445 was 892.0 meters, and the entire section was sedimentary. Acoustic basement was not reached, but may not be very far below the depth of maximum penetration.

The preservation of foraminifers and nannofossils was excellent in samples recovered from Pleistocene, Pliocene, and upper-Miocene rocks. This fauna is tropical. However, in the early Miocene and late Oligocene, the foraminifer and nannofossil species represent colder water. The Eocene fauna is tropical. The depth of deposition was well above the CCD from the late Eocene onward, and probably above the lysocline from latest Eocene to the present (Figure 20). The depth of deposition during the middle Eocene was most likely at or slightly below the CCD, apparently following the general Pacific CCD curve of van Andel et al. (1975).

Discontinuities in floral associations in the middle to early Oligocene chalks of unit IVd suggest that a hiatus may occur between Cores 57-5 and 59-4, encompassing a major part of the early and middle Oligocene. The discontinuity consists of an abrupt occurrence of welldeveloped late-Eocene assemblages below Core 59-5, whereas no Eocene assemblage exists in the overlying sediment. A similar discrepancy was also observed in cores between 57-4 and 57-5, where an early-Oligocene assemblage directly underlies an assemblage of the late middle Oligocene. Because this sequence is heavily reworked, the paleontological evidence indicates a hiatus lasting at least $8 \mathrm{~m} . \mathrm{y}$.

Sedimentation at Site 445 was mainly resedimentation of biogenic pelagic oozes by turbidity currents and slumping, and of terrigenous and volcaniclastic sands and conglomerates by turbidity currents, fluidizedsediment flow, debris flow, and slumping. Evidence for resedimentation by turbidity currents includes graded terrigenous and volcaniclastic foraminifer sands; graded sequences, $\mathrm{T}(\mathrm{a}, \mathrm{b}, \mathrm{e})$; and sharp scours. Most of the graded beds contain fossils reworked from shallower water depths. The interbedded pelagic sediments contain deeper-water fossils. Evidence for fluidized-sediment flow is found in conglomerate deposits organized into a framework conglomerate with a fabric. Many of these conglomerates contain specimens of the large shallowwater foraminifer Nummulites; these platy tests and other platy clasts define the fabric of such conglomerates. Evidence for deposition by debris flow consists again is found in conglomerates, but such conglomerates are supported by a mudstone or muddy-sandstone matrix, and the gravel-sized clasts display a dispersed fabric. Much of the sequence, particularly the sandstones, conglomerates, and mudstones, and chalks and 
TABLE 7

Summary of Physical Properties of Sediments, Site 445

\begin{tabular}{|c|c|c|c|c|c|c|c|}
\hline $\begin{array}{c}\text { Sample } \\
\text { (interval in } \mathrm{cm} \text { ) }\end{array}$ & Lithology & $\begin{array}{l}\text { Sonic } \\
\text { Velocity } \\
(\mathrm{km} / \mathrm{s})\end{array}$ & $\begin{array}{l}\text { Thermal } \\
\text { Conductivity } \\
\text { (mcal/cm-s- }{ }^{\circ} \mathrm{C} \text { ) }\end{array}$ & $\begin{array}{l}\text { Shear Strength } \\
\left(\times 10^{-5} \text { dynes } / \mathrm{cm}^{2}\right)\end{array}$ & $\begin{array}{l}\text { Wet-Bulk } \\
\text { Density } \\
\left(\mathrm{g} / \mathrm{cm}^{3}\right)\end{array}$ & $\begin{array}{c}\text { Porosity } \\
(\%)\end{array}$ & $\begin{array}{c}\text { Water } \\
\text { Content } \\
(\%)\end{array}$ \\
\hline $445-1-2,125-128$ & \multirow{2}{*}{ nannofossil ooze } & - & - & 0.05 & - & - & - \\
\hline $1-3,96-99$ & & - & - & 0.00 & - & - & - \\
\hline $1-4,83-86$ & $"$ & - & - & 0.38 & - & - & - \\
\hline $1-4,144-150$ & $"$ & - & - & - & 1.54 & 69.43 & 46.09 \\
\hline $1-5,71-73$ & $"$ & - & - & 0.10 & 1.58 & 70.62 & 45.78 \\
\hline $1-6,77-90$ & " & - & 2.542 & 0.10 & - & - & - \\
\hline $2-1,90-92$ & " & - & - & 0.02 & 1.52 & 72.85 & 49.08 \\
\hline $2-2,110-112$ & " & - & - & 1.34 & - & - & - \\
\hline $2-3,136-138$ & $"$ & - & - & 2.11 & - & - & - \\
\hline $2-4,110-112$ & $"$ & - & - & 0.67 & - & - & - \\
\hline $3-1,120-122$ & $"$ & - & - & 0.96 & - & - & - \\
\hline $3-2,120-122$ & $"$ & - & - & 1.24 & - & - & - \\
\hline $3-3,69-71$ & $"$ & - & - & 0.62 & - & - & - \\
\hline $3-4,69-71$ & $"$ & - & - & 1.24 & - & - & - \\
\hline $3-5,30-32$ & $"$ & - & - & 1.72 & 1.60 & 67.16 & 42.92 \\
\hline $3-6,120-122$ & $"$ & - & - & 0.86 & - & - & - \\
\hline $3-7,20-22$ & $"$ & - & - & 2.49 & - & - & - \\
\hline $4-1,20-22$ & $"$ & - & - & 1.15 & - & - & - \\
\hline $4-2,110-112$ & $"$ & - & - & 0.10 & - & - & - \\
\hline $4-4,44-46$ & " & - & - & 0.86 & - & - & - \\
\hline $4-5,42-52$ & $"$ & 1.568 & 2.811 & 0.77 & 1.54 & 59.71 & 39.67 \\
\hline $4-6,44-46$ & $"$ & - & - & 0.48 & - & - & - \\
\hline $6-5,144-150$ & $"$ & - & - & - & 1.63 & 63.41 & 39.75 \\
\hline $6-6,64-74$ & $"$ & 1.527 & 2.878 & 2.39 & 1.68 & 65.51 & 39.83 \\
\hline $7-5,90-100$ & $"$ & 1.509 & 2.867 & 2.39 & 1.63 & 65.32 & 41.03 \\
\hline $8-3,79-81$ & $"$ & - & - & 1.39 & - & - & - \\
\hline $8-5,110-120$ & $"$ & 1.517 & 2.875 & 2.49 & 1.58 & 68.41 & 44.39 \\
\hline $8-5,110-120$ & $"$ & $1.508^{*}$ & - & - & - & - & - \\
\hline $10-5,130-140$ & $"$ & 1.592 & 2.917 & 4.98 & 1.66 & 62.22 & 38.40 \\
\hline $11-4,87-89$ & $"$ & - & - & 1.53 & - & - & - \\
\hline $11-4,90-100$ & $"$ & 1.553 & 3.222 & 6.70 & 1.74 & 67.28 & 39.70 \\
\hline $11-4,144-150$ & $"$ & - & - & - & 1.70 & 62.79 & 37.93 \\
\hline $12-2,40-50$ & $"$ & 1.618 & 2.875 & - & 1.76 & 79.98 & 46.45 \\
\hline $13-3,62-72$ & $"$ & 1.571 & 2.742 & - & 1.60 & 68.14 & 43.73 \\
\hline $14-1,122-132$ & $"$ & 1.490 & 2.878 & 3.26 & 1.55 & 68.68 & 45.39 \\
\hline $15-1,126-136$ & $"$ & 1.535 & 2.900 & - & 1.72 & 64.26 & 38.21 \\
\hline $16-2,84-94$ & $"$ & 1.552 & 3.306 & - & 1.60 & 57.38 & 36.76 \\
\hline $17-1,40-50$ & $"$ & 1.577 & 3.411 & - & 1.72 & 61.20 & 36.56 \\
\hline $17-1,140-150$ & $"$ & - & - & - & 1.76 & 57.48 & 33.40 \\
\hline $18-3,69-79$ & $"$ & 1.579 & - & - & 1.70 & 53.84 & 32.44 \\
\hline $18-4,136-146$ & nannofossil chalk & 1.552 & - & - & 1.70 & 61.34 & 36.95 \\
\hline $20-2,87-97$ & $"$ & 1.533 & 3.167 & 2.68 & 1.75 & 62.99 & 36.91 \\
\hline $21-1,62-72$ & $"$ & 1.550 & 3.389 & - & - & - & - \\
\hline $22-1,144-150$ & $"$ & - & - & - & 1.66 & 52.70 & 32.51 \\
\hline $22-1,144-150$ & $"$ & - & - & - & 1.78 & 54.32 & 31.30 \\
\hline $22-2,62-75$ & $"$ & 1.554 & 3.294 & - & - & - & - \\
\hline $23-1,70-71$ & $"$ & - & - & - & 1.62 & 61.49 & 38.98 \\
\hline $23-2,35-45$ & $"$ & 1.543 & 3.028 & - & - & - & - \\
\hline $24-2,78-79$ & $"$ & - & - & - & 1.79 & 55.07 & 31.49 \\
\hline $24-3,124-134$ & $"$ & 1.659 & 3.422 & - & - & - & - \\
\hline $25-1,24-25$ & $"$ & - & - & - & 1.77 & 53.20 & 30.86 \\
\hline $25-2,47-57$ & $"$ & 1.604 & 2.933 & - & - & - & - \\
\hline $26-3,102-103$ & $"$ & - & - & - & 1.74 & 56.32 & 33.24 \\
\hline $27-4,140-150$ & $"$ & - & - & - & 1.68 & 66.20 & 40.37 \\
\hline $28-2,5-15$ & & 1.600 & 2.781 & - & 1.68 & 64.87 & 39.66 \\
\hline $29-4,94-104$ & $"$ & 1.712 & 3.067 & - & 1.84 & 55.05 & 30.72 \\
\hline $30-3,14-29$ & $"$ & 1.657 & 3.236 & - & 1.72 & 57.38 & 34.25 \\
\hline $31-1,85-95$ & $"$ & - & 3.097 & - & - & - & - \\
\hline $31-4,110-121$ & $"$ & 1.663 & 3.394 & - & 1.75 & 53.46 & 31.36 \\
\hline $32-1,48-58$ & & 1.807 & 2.892 & - & 1.50 & 69.50 & 47.56 \\
\hline $32-i, 72-82$ & $"$ & 1.736 & 3.983 & - & 1.67 & 59.28 & 36.36 \\
\hline $32-2,140-150$ & $"$ & - & - & - & 1.65 & 62.66 & 38.93 \\
\hline
\end{tabular}


TABLE 7 - Continued

\begin{tabular}{|c|c|c|c|c|c|c|c|}
\hline $\begin{array}{c}\text { Sample } \\
\text { (interval in } \mathrm{cm} \text { ) }\end{array}$ & Lithology & $\begin{array}{l}\text { Sonic } \\
\text { Velocity } \\
(\mathrm{km} / \mathrm{s})\end{array}$ & $\begin{array}{c}\text { Thermal } \\
\text { Conductivity } \\
\text { (mcal/cm-s- }{ }^{\circ} \mathrm{C} \text { ) }\end{array}$ & $\begin{array}{c}\text { Shear Strength } \\
\left(\times 10^{-5} \text { dynes } / \mathrm{cm}^{2}\right)\end{array}$ & $\begin{array}{l}\text { Wet-Bulk } \\
\text { Density } \\
\left(\mathrm{g} / \mathrm{cm}^{3}\right)\end{array}$ & $\begin{array}{l}\text { Porosity } \\
(\%)\end{array}$ & $\begin{array}{c}\text { Water } \\
\text { Content } \\
(\%)\end{array}$ \\
\hline $445-33-2,50-60$ & $"$ & 1.733 & 3.467 & - & - & - & - \\
\hline $34-2,37-40$ & $"$ & 1.799 & - & - & - & - & - \\
\hline $34-2,46-56$ & " & - & - & - & 1.79 & 54.32 & 31.13 \\
\hline $34-2,58-59$ & nannofossil chalk & - & - & - & 1.76 & 55.49 & 32.36 \\
\hline $35-2,78-81$ & " & 1.716 & - & - & - & 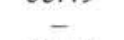 & - \\
\hline $35-2,83-93$ & " & - & 3.511 & - & 1.79 & 57.14 & 32.62 \\
\hline $36-2,66-76$ & $"$ & 1.705 & 3.364 & - & 1.73 & 63.09 & 37.32 \\
\hline $36-2,114-124$ & $"$ & - & 2.903 & - & - & - & - \\
\hline $37-2,68-78$ & " & 1.730 & 3.700 & - & 1.91 & 50.11 & 26.95 \\
\hline $37-4,23-33$ & $"$ & 1.865 & 3.389 & - & 1.95 & 53.13 & 27.92 \\
\hline $37-4,140-150$ & mudstone & - & - & - & 1.73 & 60.90 & 36.04 \\
\hline $38-3,39-49$ & nannofossil chalk & 1.802 & 4.111 & - & 1.96 & 51.32 & 26.80 \\
\hline $39-1,9-19$ & $"$ & - & 3.969 & - & - & - & - \\
\hline $39-1,94-97$ & $"$ & 1.892 & - & - & 1.94 & 58.69 & 30.94 \\
\hline $40-2,146-150$ & $"$ & 1.929 & 4.414 & - & 2.06 & 40.91 & 20.32 \\
\hline $41-6,33-43$ & $"$ & 1.999 & 4.081 & - & 2.11 & 41.57 & 20.18 \\
\hline $42-4,104-114$ & $"$ & 1.780 & 3.236 & - & 1.91 & 54.25 & 29.11 \\
\hline $42-5,90-100$ & $"$ & - & - & - & 1.79 & 55.33 & 31.68 \\
\hline $43-2,100-103$ & $"$ & 2.018 & - & - & 2.21 & 43.26 & 20.09 \\
\hline $44-3,130-133$ & $"$ & 1.958 & - & - & 2.23 & 46.06 & 21.18 \\
\hline $45-3,31-34$ & $"$ & 2.143 & - & - & 2.33 & 47.78 & 21.00 \\
\hline $46-3,28-30$ & $"$ & - & - & - & 1.91 & 44.09 & 23.67 \\
\hline $46-4,28-31$ & $"$ & 1.996 & - & - & 2.05 & 49.71 & 24.86 \\
\hline $47-3,73-76$ & $"$ & 1.937 & - & - & 2.13 & 47.76 & 22.92 \\
\hline $47-4,90-100$ & $"$ & - & - & - & 2.01 & 44.75 & 22.75 \\
\hline $48-2,26-36$ & $"$ & 2.524 & 5.144 & - & 2.14 & 41.56 & 19.89 \\
\hline $49-3,54-64$ & $"$ & 2.252 & 4.511 & - & 2.31 & 48.61 & 21.56 \\
\hline $50-1,38-48$ & $"$ & 2.358 & 4.492 & - & 2.26 & 47.08 & 21.36 \\
\hline $51-3,108-118$ & $"$ & 2.086 & 3.728 & - & 1.86 & 45.30 & 24.97 \\
\hline $52-2,86-96$ & $"$ & 2.275 & 4.997 & - & 1.99 & 36.65 & 18.84 \\
\hline $52-2,90-100$ & $"$ & - & - & - & 1.90 & 48.42 & 26.17 \\
\hline $53-2,34-44$ & $"$ & 2.111 & 4.094 & - & 1.92 & 47.10 & 25.12 \\
\hline $54-2,38-48$ & $"$ & 2.110 & 4.178 & - & 1.93 & 42.36 & 22.47 \\
\hline $55-3,38-48$ & $"$ & 2.065 & 4.228 & - & 1.95 & 46.89 & 24.59 \\
\hline $56-3,33-43$ & $"$ & 2.081 & 3.928 & - & 1.92 & 48.98 & 26.12 \\
\hline $57-3,73-83$ & $"$ & 2.124 & 3.381 & - & 1.76 & 53.45 & 31.04 \\
\hline $58-1,103-106$ & $"$ & 2.376 & - & - & - & - & - \\
\hline $58-2,23-33$ & $"$ & 2.407 & 5.036 & - & - & - & - \\
\hline $59-4,139-149$ & $"$ & 1.988 & 3.386 & - & 1.85 & 47.45 & 26.25 \\
\hline $60-1,38-48$ & $"$ & 2.106 & 2.878 & - & 1.92 & 47.80 & 25.45 \\
\hline $61-3,67-69$ & $"$ & 1.848 & 2.569 & - & 1.59 & 59.31 & 38.30 \\
\hline $62-2,44-47$ & $"$ & 1.948 & - & - & 1.77 & 55.33 & 32.02 \\
\hline $62-2,143-150$ & $"$ & - & 2.422 & - & - & - & - \\
\hline $62-2,140-150$ & $"$ & - & - & - & 1.75 & 56.95 & 33.38 \\
\hline $63-2,127-140$ & $"$ & 1.884 & 2.486 & - & 1.64 & 59.79 & 37.35 \\
\hline $64-3,18-28$ & $"$ & 1.823 & 2.594 & - & 1.61 & 59.06 & 37.51 \\
\hline $65-1,42-52$ & $"$ & 1.773 & 2.464 & - & 1.55 & 66.27 & 43.83 \\
\hline $65-2,90-100$ & radiolarite & - & - & - & 1.46 & 66.24 & 46.60 \\
\hline $65-3,42-52$ & radiolarian ooze & 1.736 & 2.575 & - & 1.46 & 61.04 & 42.92 \\
\hline $65-3,92-95$ & chert & 2.160 & - & - & - & - & - \\
\hline $66-2,16-26$ & radiolarite & 1.839 & 2.906 & - & 1.68 & 63.00 & 38.44 \\
\hline $67-1,19-22$ & mudstone & 3.321 & - & - & 2.33 & 24.73 & 10.89 \\
\hline $68-1,78-88$ & siltstone & 2.329 & 3.450 & - & 2.08 & 43.11 & 21.26 \\
\hline $68-2,41-51$ & $"$ & 2.538 & 2.989 & - & 2.10 & 37.52 & 18.26 \\
\hline $69-1,24-26$ & mudstone & - & - & - & 2.19 & 32.86 & 15.37 \\
\hline $69-2,100-103$ & " & 2.088 & - & - & 2.02 & 44.86 & 22.75 \\
\hline $69-3,28-38$ & sandstone & 3.030 & 3.142 & - & 2.22 & 36.53 & 16.84 \\
\hline $70-2,7-17$ & claystone & 2.065 & 3.275 & - & 2.78 & 47.18 & 24.78 \\
\hline $71-1,38-45$ & mudstone & 2.537 & 3.375 & - & 1.93 & 41.21 & 21.92 \\
\hline $72-1,43-46$ & $"$ & 2.265 & - & - & 2.08 & 39.66 & 19.54 \\
\hline $73-1,80-83$ & $"$ & 2.078 & - & - & 2.01 & 42.52 & 21.68 \\
\hline $73-3,84-94$ & sandstone & 2.061 & 6.531 & - & 1.96 & 42.87 & 22.39 \\
\hline $74-2,46-49$ & mudstone & 2.244 & - & - & 2.01 & 40.16 & 20.42 \\
\hline
\end{tabular}


TABLE 7 - Continued

\begin{tabular}{|c|c|c|c|c|c|c|c|}
\hline $\begin{array}{c}\text { Sample } \\
\text { (interval in } \mathrm{cm} \text { ) }\end{array}$ & Lithology & $\begin{array}{l}\text { Sonic } \\
\text { Velocity } \\
(\mathrm{km} / \mathrm{s})\end{array}$ & $\begin{array}{c}\text { Thermal } \\
\text { Conductivity } \\
\text { (mcal } / \mathrm{cm}-\mathrm{s}^{\circ} \mathrm{C} \text { ) }\end{array}$ & $\begin{array}{c}\text { Shear Strength } \\
\left(\times 10^{-5} \text { dynes } / \mathrm{cm}^{2}\right)\end{array}$ & $\begin{array}{l}\text { Wet-Bulk } \\
\text { Density } \\
\left(\mathrm{g} / \mathrm{cm}^{3}\right)\end{array}$ & $\begin{array}{l}\text { Porosity } \\
\text { (\%) }\end{array}$ & $\begin{array}{c}\text { Water } \\
\text { Content } \\
(\%)\end{array}$ \\
\hline $445-75-2,39-42$ & mudstone & 2.152 & - & - & 2.03 & 38.72 & 19.59 \\
\hline $75-5,43-53$ & ", & 2.182 & 3.156 & - & 1.93 & 42.72 & 22.66 \\
\hline $76-3,106-116$ & $"$ & 2.282 & 3.211 & - & 2.11 & 36.75 & 17.82 \\
\hline $77-1,137-147$ & $"$ & 2.257 & 3.436 & - & 2.09 & 36.64 & 17.99 \\
\hline $78-4,25-35$ & $"$ & 2.067 & 3.194 & - & 2.06 & 48.48 & 24.14 \\
\hline $79-2,125-135$ & $"$ & 2.049 & 3.236 & - & 2.01 & 47.47 & 24.25 \\
\hline $80-1,135-145$ & ", & 2.037 & 3.231 & - & 1.96 & 47.25 & 24.68 \\
\hline $80-4,90-100$ & $"$ & - & - & - & 1.95 & 47.57 & 24.95 \\
\hline $81-3,56-66$ & $"$ & 1.994 & 3.033 & - & 2.03 & 56.91 & 29.69 \\
\hline $82-1,70-80$ & $"$ & 2.045 & 3.142 & - & 1.97 & 46.40 & 24.10 \\
\hline $83-3,76-79$ & $"$ & 2.062 & - & - & 1.97 & 45.99 & 23.91 \\
\hline $84-1,100-110$ & $"$ & 2.058 & 3.250 & - & 1.97 & 47.71 & 24.80 \\
\hline $85-3,97-107$ & $"$ & 2.110 & 3.239 & - & 2.03 & 42.35 & 21.38 \\
\hline $86-2,56-59$ & $"$ & 2.076 & - & - & 1.97 & 45.76 & 23.75 \\
\hline $87-4,40-50$ & siltstone & 2.162 & 3.328 & - & 2.04 & 40.66 & 20.43 \\
\hline $88-3,58-68$ & mudstone & 2.305 & 2.719 & - & 2.04 & 43.94 & 22.10 \\
\hline $89-3,75-85$ & $"$ & 2.092 & 3.158 & - & 2.02 & 44.46 & 22.59 \\
\hline $90-1,25-35$ & sandstone & 2.949 & 4.428 & - & 2.18 & 32.06 & 15.05 \\
\hline $91-2,50-66$ & $"$ & 2.561 & 3.089 & - & 2.07 & 33.41 & 16.51 \\
\hline $92-3,95-105$ & $"$ & 3.192 & 2.783 & - & 2.32 & 28.44 & 12.55 \\
\hline $93-3,90-100$ & conglomerate & 3.246 & 3.558 & - & 2.30 & 26.64 & 11.85 \\
\hline $94-2,96-106$ & " & 3.059 & 3.597 & - & 2.31 & 26.30 & 11.68 \\
\hline
\end{tabular}

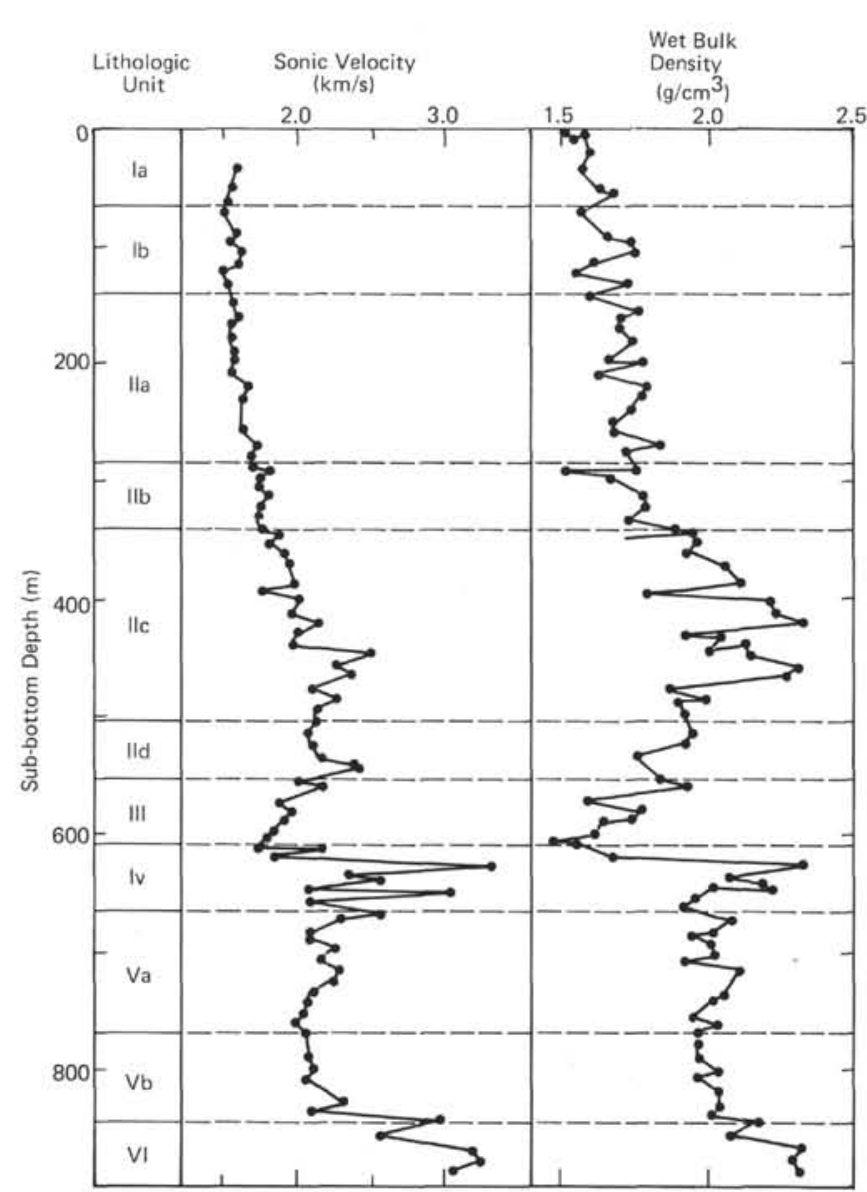

Figure 15. Sonic velocity and wet-bulk density versus depth for Site 445 sediments. limestones of units II, V, and VI, show features clearly indicative of slumping, including rotation of large blocks (some as thick as $5 \mathrm{~m}$ ), microfaults, pull-apart fractures, and well-developed slump folds. Slumping of sediments involved both the chalks and the volcaniclastic sandstones. This style of sedimentation has been observed before both in the South Fiji and New Hebrides marginal basins (Klein, 1975a,b), and off the Line Islands in the central Pacific (Cook et al., 1976).

The rates of sediment accumulation reflect this style of sedimentation. Rates are very low for the purely pelagic intervals, and moderate for the resedimented biogenic pelagic carbonates. Rates of sediment accumulation are very high for the sandstones and conglomerates of unit $\mathrm{V}$. This pattern of sedimentation rates (an early history of rapid sedimentation, and then a decrease with time) is identical to a similar change in sediment accumulation rates reported by Andrews, Packham, et al. (1975) from the New Hebrides Basin (Site 286), and from the South Fiji Basin (Site 285).

The volume of sediment deposited by resedimentation processes is high, perhaps as much as 70 per cent for unit $\mathrm{V}$, and perhaps as much as 80 per cent for the upper carbonate units. (See White et al., this volume.)

Organic-carbon content decreases exponentially to a depth of about 100 meters, below which it remains constant throughout the pelagic sequence. In the deepest part of the section, organic-carbon content increases again, probably reflecting the contribution of resedimented terrigenous organic material carried in the debris flows.

The observed decrease in organic carbon with sediment age and depth in these pelagic sediments is analogous to the trends observed in the hemipelagic sediments 


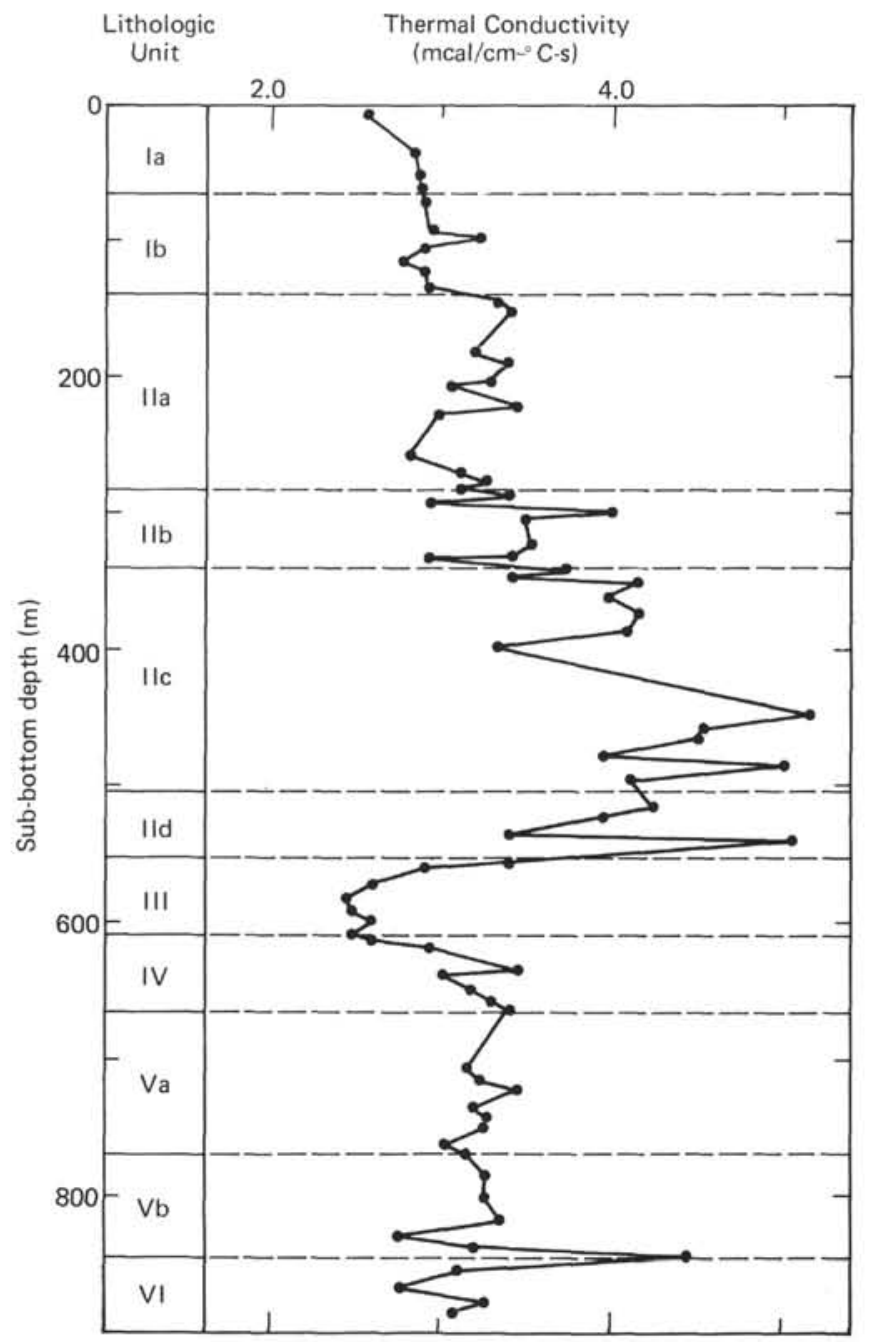

Figure 16. Thermal conductivity versus depth for Site 445 sediments.

at Sites 442,443 , and 444 . Approximately equal lengths of time (about $4 \mathrm{~m} . \mathrm{y}$ ) are required for the degradation process to be completed in the pelagic and hemipelagic environments. Both the initial and final organic-carbon contents are only about half of those in the relatively pure hemipelagic clays at Sites 442 and 443 ; the explanation for this probably lies in the absence of organic matter adsorbed on clay surfaces at Site 445 .

The $p \mathrm{H}$ of the sediments averages 7.46 , alkalinity averages $1.6 \mathrm{meq} / \mathrm{kg}$, salinity averages 35.7 per mill, and chlorinity averages 19.96 per mill.

Table 8 summarizes average physical properties of the sediments recovered at Site 445 . Sonic velocity increases in the older units with depth, and from this a minimum elevation of the sediment/basement boundary was estimated at approximately 950 meters sub-bottom.

Paleomagnetism measurements of sediment samples recovered at Site 445 show that there is a systematic change in magnetic inclination with depth. The change indicates that Site $\mathbf{4 4 5}$ has drifted in a net northerly

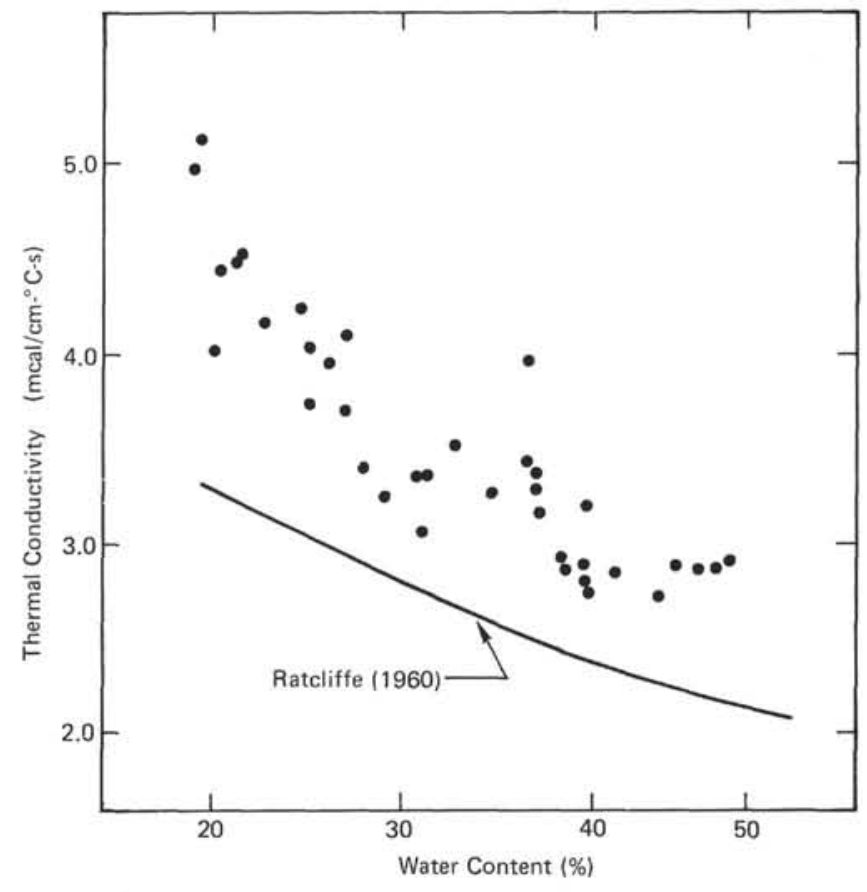

Figure 17. Relationship between thermal conductivity and water content for nannofossil oozes and chalks in Cores 1 through 58, Site 445. Also shown is the relationship for deep-ocean sediments established by Ratcliffe (1960).

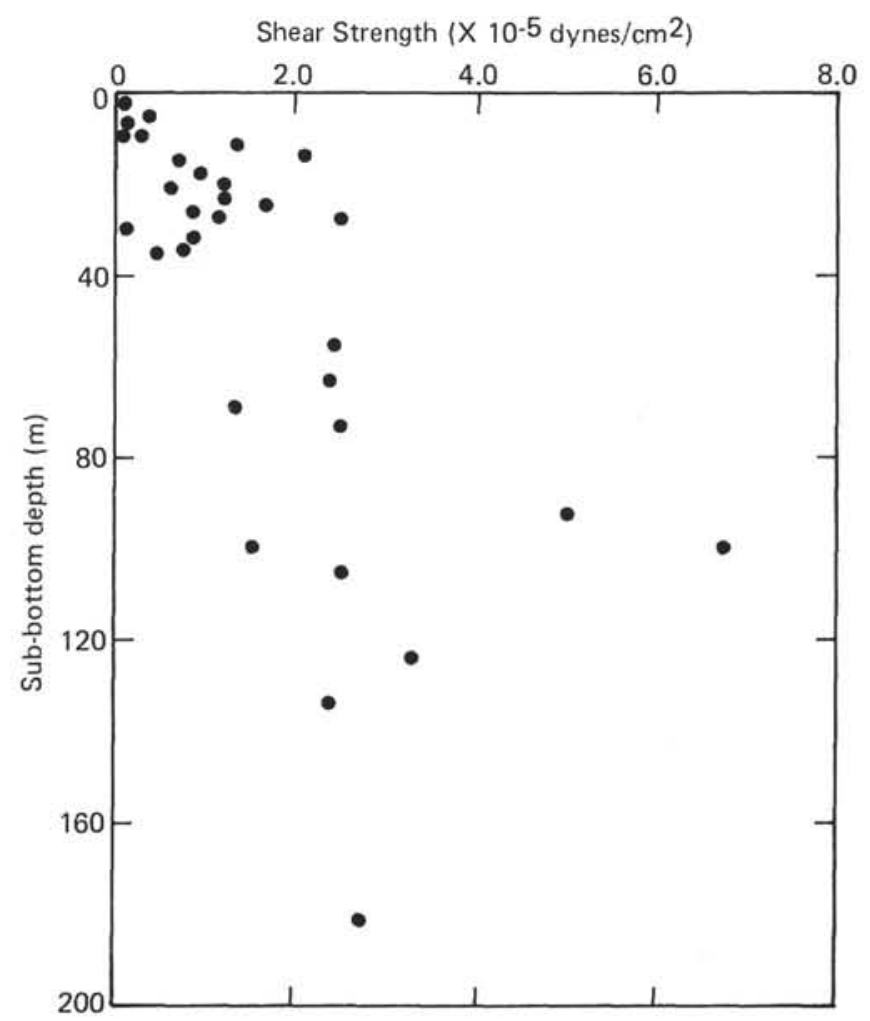

Figure 18. Shear strength versus depth for Site 445 sediments. 


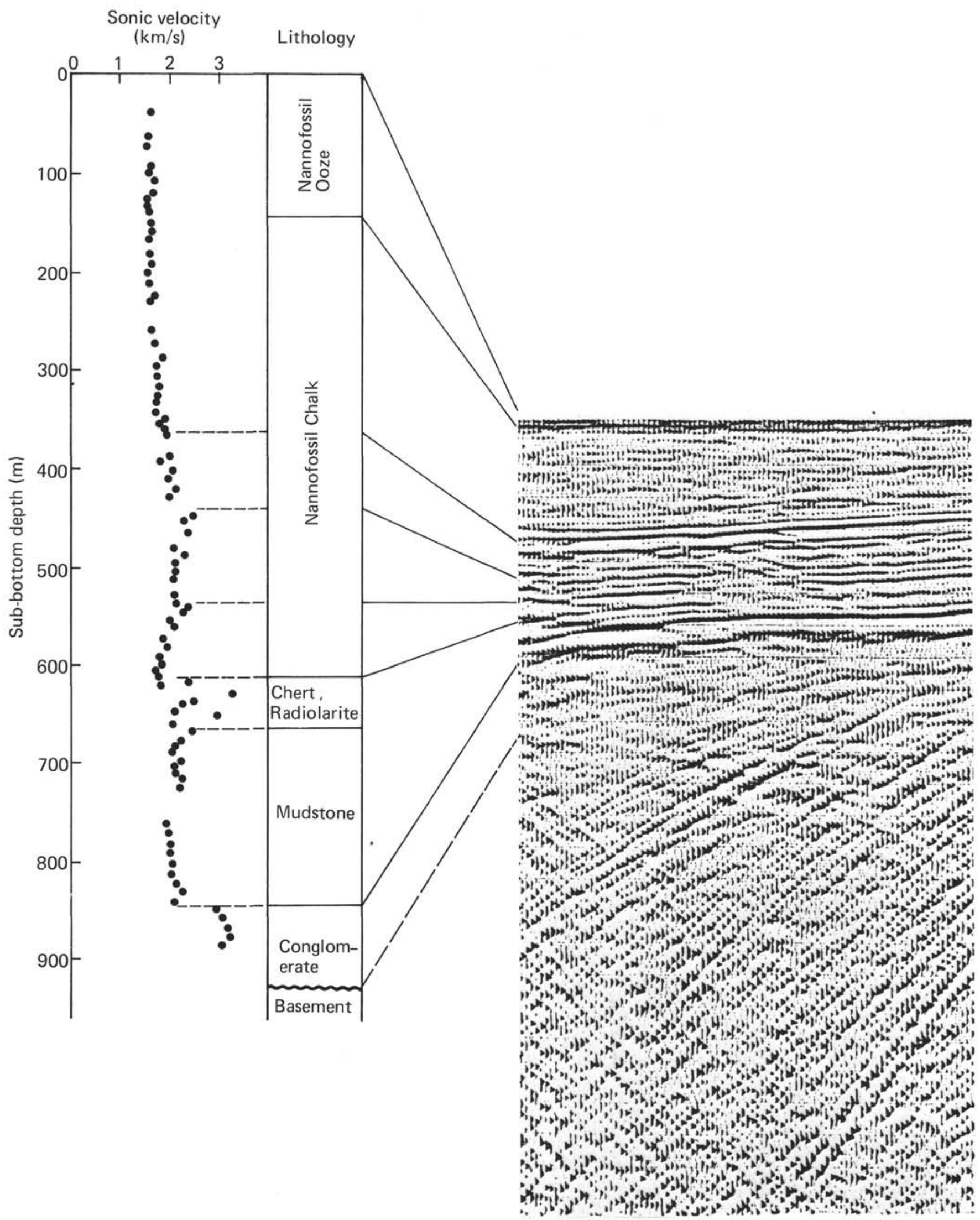

Figure 19. Site 445 stratigraphic section and corresponding seismic profile of $R / V$ Kaiyo-Maru. 


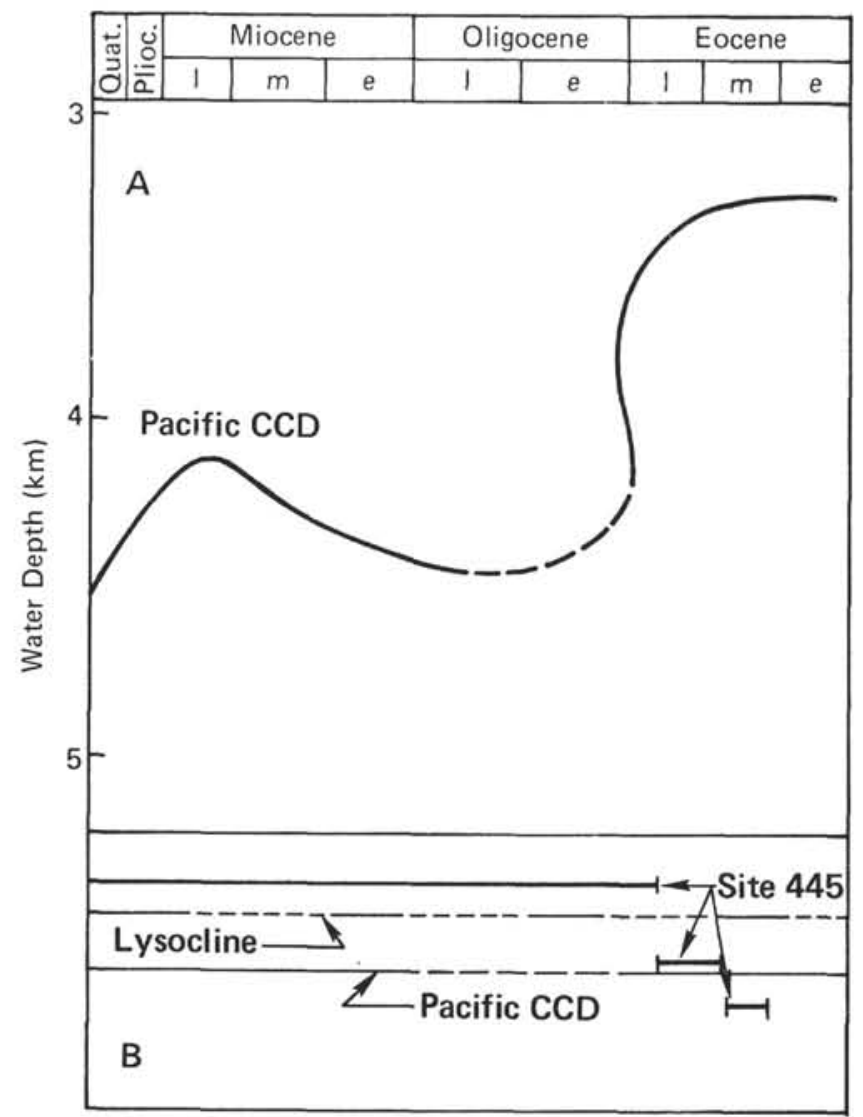

Figure 20. A. General curve showing estimated water depth of CCD in Pacific Ocean (after van Andel et al., 1975, p. 47, fig. 29). B. Relative depth of deposition at Site 445 compared to CCD curve for Pacific Ocean.

TABLE 8

Average Values and Ranges of Sonic Velocity, Shear Strength, and Thermal Conductivity for Sediments, Site 445

\begin{tabular}{lccc}
\hline & $\begin{array}{c}\text { Sonic Velocity } \\
(\mathrm{km} / \mathrm{s})\end{array}$ & $\begin{array}{c}\text { Shear Strength } \\
\left(\times 10^{5} \text { dynes } / \mathrm{cm}^{2}\right)\end{array}$ & $\begin{array}{c}\text { Thermal Conductivity } \\
\left(\mathrm{mcal} / \mathrm{cm}-\mathrm{s}^{\circ} \mathrm{C}\right)\end{array}$ \\
\hline $\begin{array}{l}\text { Average } \\
\text { Range }\end{array}$ & $\begin{array}{c}2.007 \\
1.490-3.321\end{array}$ & $\begin{array}{c}1.60 \\
0.0-6.70\end{array}$ & $\begin{array}{c}3.421 \\
2.422-6.531\end{array}$ \\
\hline
\end{tabular}

direction over the last 47 m.y. At $47 \mathrm{Ma}$, Site 445 was close to the equator; it has migrated nearly $2000 \mathrm{~km}$ to its present position at an average rate of $4.4 \mathrm{~cm} / \mathrm{yr}$. These data are in agreement with results obtained by Louden $(1976,1977)$ in the West Philippine Basin. Intensity of natural remanent magnetization is greater in deeper parts, which appear to contain higher amounts of volcanogenic magnetite.

\section{Conclusions}

Our findings permit us to draw the following conclusions about the geological history of Site 445 :

1. Although we did not reach acoustic basement, the systematic increase in sonic velocity with depth suggests that basement may occur not far below our maximum depth of penetration.
2. The depositional surface at Site 445 was well above the CCD during most of its depositional history.

3. The dominant motif of sedimentation at Site 445 was one of resedimentation of pelagic biogenic sediment, terrigenous sediment, and volcaniclastic sediment by turbidity currents, slump processes, fluidized-sediment flows, and debris flows.

4. The occurrence of Nummulites in debris flow and fluidized-sediment-flow conglomerates indicates clearly that it and associated shallow-water bivalves, bryozoans, and gastropods were emplaced by resedimentation processes from shallower water. This origin for Nummulities is significant to consideration of dredge recovery of Nummulities-bearing rocks from the Amami Plateau and the Daito Ridge (Mizuno et al., 1975). The combined evidence from dredge sampling and our drilling indicates that the Daito Ridge, at present nearly 1300 meters below sea level, probably subsided no more than 1200 meters between Eocene time and the present.

5. Paleomagnetism data indicate that Site 445 and the surrounding Daito Ridge were around the equator at $47 \mathrm{Ma}$. Since then, northward drift averaging $4.4 \mathrm{~cm} / \mathrm{yr}$ has occurred.

\section{REFERENCES}

Andrews, J. E., Packham, G. H., et al., 1975. Init. Repts. $D S D P$, 30: Washington (U. S. Govt. Printing Office).

Berggren, W. A., 1972. A Cenozoic time-scale - some implications for regional geology and paleogeography. Lethaia, $5,195-215$.

Berggren, W. A., and Van Couvering, J. A., 1974. The late Neogene biostratigraphy, geochronology and paleoclimatology of the last 15 million years in marine and continental sequences. Palaeogeography, Palaeoclimatology Palaeoecology, 16, 1-216.

Bukry, D., 1965. Coccolith and silicoflagellate stratigraphy, northwestern Pacific Ocean, Deep Sea Drilling Project Leg 32. In Larson, R. L., Moberly, R. M., Jr., et al., Init. Repts. DSDP, 32: Washington (U. S. Govt. Printing Office), pp. 677-718.

Cook, H. E., Jenkyns, H. C., and Kelts, K. R., 1976. Redeposited sediments along the Line Islands, equatorial Pacific. In Schlanger, S. O., Jackson, E. D., et at.,Init. Repts. DSDP, 33: Washington (U. S. Govt. Printing Office), pp. 837-848.

Cooper, A. K., Marlow, M. K., and Scholl, D. W., 1976. Mesozoic magnetic lineations in the Bering Sea marginal Basin. J. Geophys. Res., 81, 1916-1934.

Davies, T. A., Weser, O. E., Luyendyk, B. P., and Kidd, R. B., 1975. Unconformities in the sediments of the Indian Ocean. Nature, 253, 15-19.

Erickson, A., 1973. Initial report on downhole temperature and shipboard thermal conductivity measurements, Leg 19 , Deep Sea Drilling Project. In Creager, J. S., Scholl, D. W., et al., Init. Repts. DSDP, 19: Washington (U. S. Govt. Printing Office), pp. 643-656.

Hilde, T. W. C., Uyeda, S., and Kroenke, L., 1977. Evolution of the western Pacific and its margin. Tectonophys., $38,145-165$.

Hyndman, R. D., Erickson, A. J., and von Herzen, R. P., 1974. Geothermal measurements on DSDP Leg 26. In Davies, T. A., Luyendyk, B. P., et al., Init. Repts. DSDP, 26: Washington (U. S. Govt. Printing Office), pp. 451-464. 
IPOD-Japan, 1977. Multi-channel seismic reflection data across the Shikoku Basin and the Daito Ridges, 1976. IPOD-Japan Basic Data Series, No. 1.

Karig, D. E., 1975. Basin genesis in the Philippine Sea. In Karig, D. E., Ingle, J. C., et al., Init. Repts. DSDP, 31: Washington (U. S., Govt. Printing Office), pp. 857-879.

Karig, D. E., Ingle, J. C., et al., 1975. Init. Repts. DSDP, 31: Washington (U. S. Govt. Printing Office).

Kennett, J. P., Burns, R. E., Andrews, J. E., Churkin, M. Jr., Davies, T. A., Dumitricà, P., Edwards, A. R. Galehouse, J. S., Packham, G. H., and van der Lingen, G. J., 1972. Australian-Antarctic continental drift, palaeocirculation changes and Oligocene deep-sea erosion. Nature, 239, 51-55.

Klein, G. deV., 1975a. Sedimentary tectonics in southwest Pacific marginal basins based on Leg 30 Deep Sea Drilling Project cores from the South Fiji, Hebrides, and Coral Sea Basins. Geol. Soc. Am. Bull., 86, 1012-1018.

1975b. Depositional facies in Leg 30 Deep Sea

Drilling Project cores. In Andrews, J. E., Packham, G. H., et al., Init. Repts. DSDP, 30: Washington (U. S. Govt. Printing Office), pp. 423-442.

Konda, I., Harada, K., Kitazato, H., Matsuoka, K., Nishida, S., Nishimura, A., Ohno, T., and Taka-ama, T., 1975. Some paleontological results of the GDP-1, $-8,-11$ cruises. In Geological Processes of the Phillipine Sea: Tokyo (Geol. Soc. Japan).

Louden, K. E., 1976. Magnetic anomalies in the West Philippine Basin. In Sutton, G. H., Manghnani, M. H., and Moberly R. M., (Eds.), The Geophysics of the Pacific Ocean Basin and Its Margins: Monogr. Am. Geophys. Union, 19, pp. 253-267.

1977. Paleomagnetism of DSDP sediments, phase shifting of magnetic anomalies, and rotation of the West Philippine Basin. J. Geophys. Res., 82, 2989-3002.

Marshall, B. V. and Erickson, A. J., 1974. Heat flow and thermal conductivity measurements, Leg 25, Deep Sea Drilling Project. In Simpson, E. S. W., Schlich, R., et al., Init. Repts. DSDP, 25: Washington (U. S. Govt. Printing Office), pp. 349-356.
Mizuno, A., and Konda, I., 1977. Eocene Larger Foraminifers from the sea floor near Oki-daito-shima Island. Bull. Geol. Survey Japan, 28, 639-648.

Mizuno, A. Okuda, Y., Tamaki, K., Kinoshita, Y., Nohara, M., Yuasa, M., Nakajima, M., Murakami, F., Terashima, S., and Ishibashi, K., 1975. Marine geology and geological history of the Daito Ridge area, northwestern Philippine Sea. Mar. Sci., 7, 484-491, 543-548.

Mizuno, A., Shiki, T., and Aoki, H., 1977. Dredged rock and piston and gravity core data from the Daito Ridges and the Kyushu-Palau Ridge in the North Philippine Sea. Geological Studies of the Ryukyu Islands, (Vol. 2), pp. 107-119.

Mizuno, A., Okuda, Y., Nagumo, S., Kagami, H., and Nasu, N., 1979. Subsidence of the Daito Ridge and associated basins, North Philippine Sea. In Watkins, J. S., Montadert, L., and Dickerson, J. (Eds.), Geological and Geophysical Investigations of Continental Margins: Mem. Am. Assoc. Petrol. Geol., 29.

Ratcliffe, E. H., 1960. The thermal conductivities of ocean sediments, J. Geophys. Res., 65, 1535-1541.

Saito, T., 1977. Late Cenozoic planktonic foraminifera datum levels: the present state of knowledge towards accomplishing Pan-Pacific stratigraphic correlation. Proc. First. Internat. Cong. Pacific Neogene Stratigraphy, 61-80.

Shiki, T., Aoki, H., Suzuki, H., Masashino, M., and Okuda, Y., 1974. Geological and petrographical results of the GDP-8 cruise in the Philippine Sea. Mar. Sci., 6, 51-55.

Shiki, T., Misawa, Y., and Konda, I., 1977. Geology and geohistory of the northwestern Philippine Sea, with special reference to the results of the recent Japanese research cruises. Mem. Fac. Sci. Kyoto Univ., Ser. Geol. and Mineral., 44, 67-78.

van Andel, T. H., Heath, G. R., and Moore, T. C., Jr., 1975. Cenozoic history and paleoceanography of the central equatorial Pacific Ocean. Geol. Soc. Am. Mem., 143.

Watts, A. B., Weissel, J. K., and Larson, R. L., 1977. Seafloor spreading in marginal basins of the western Pacific. Tectonophys., 37, 167-181. 


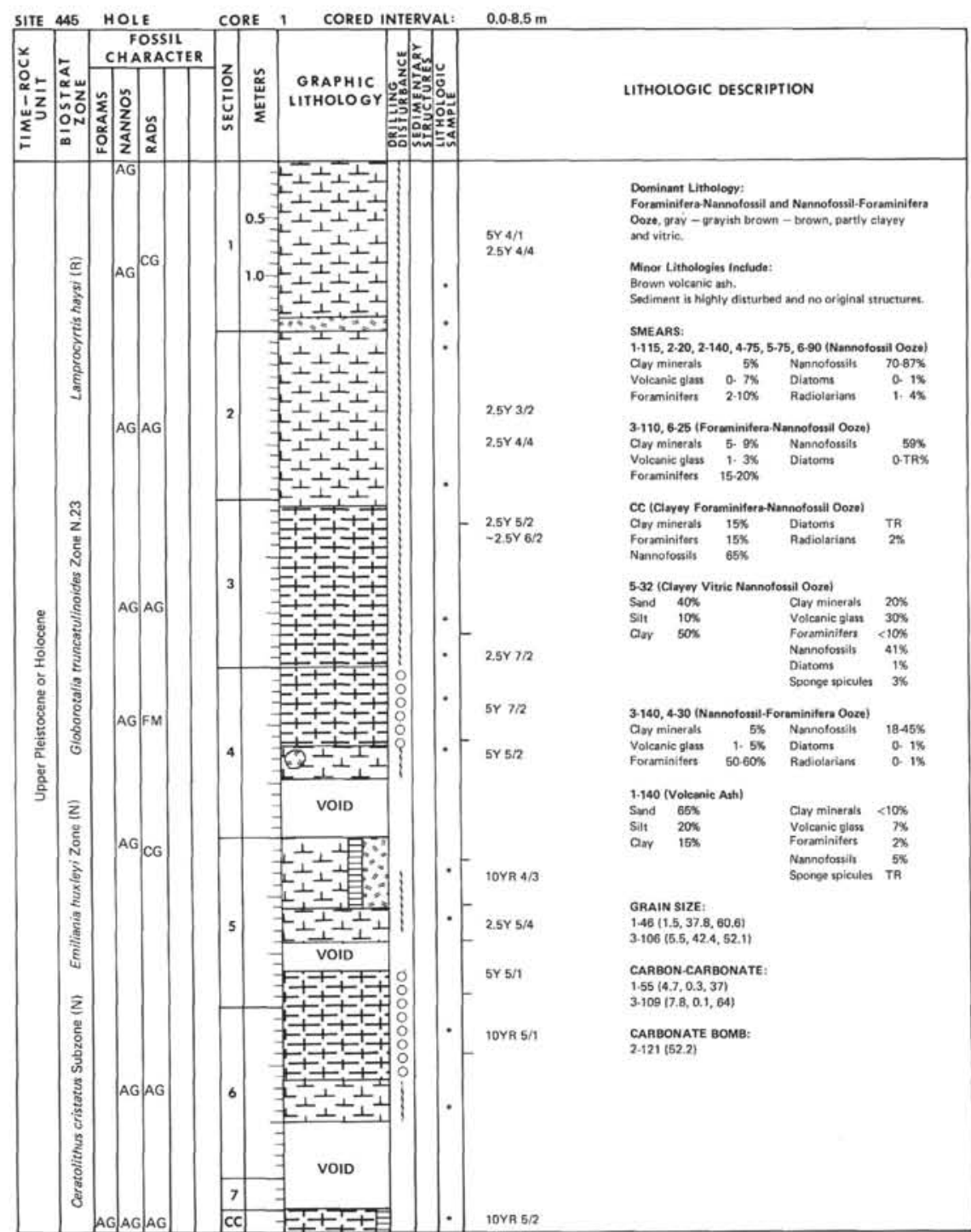

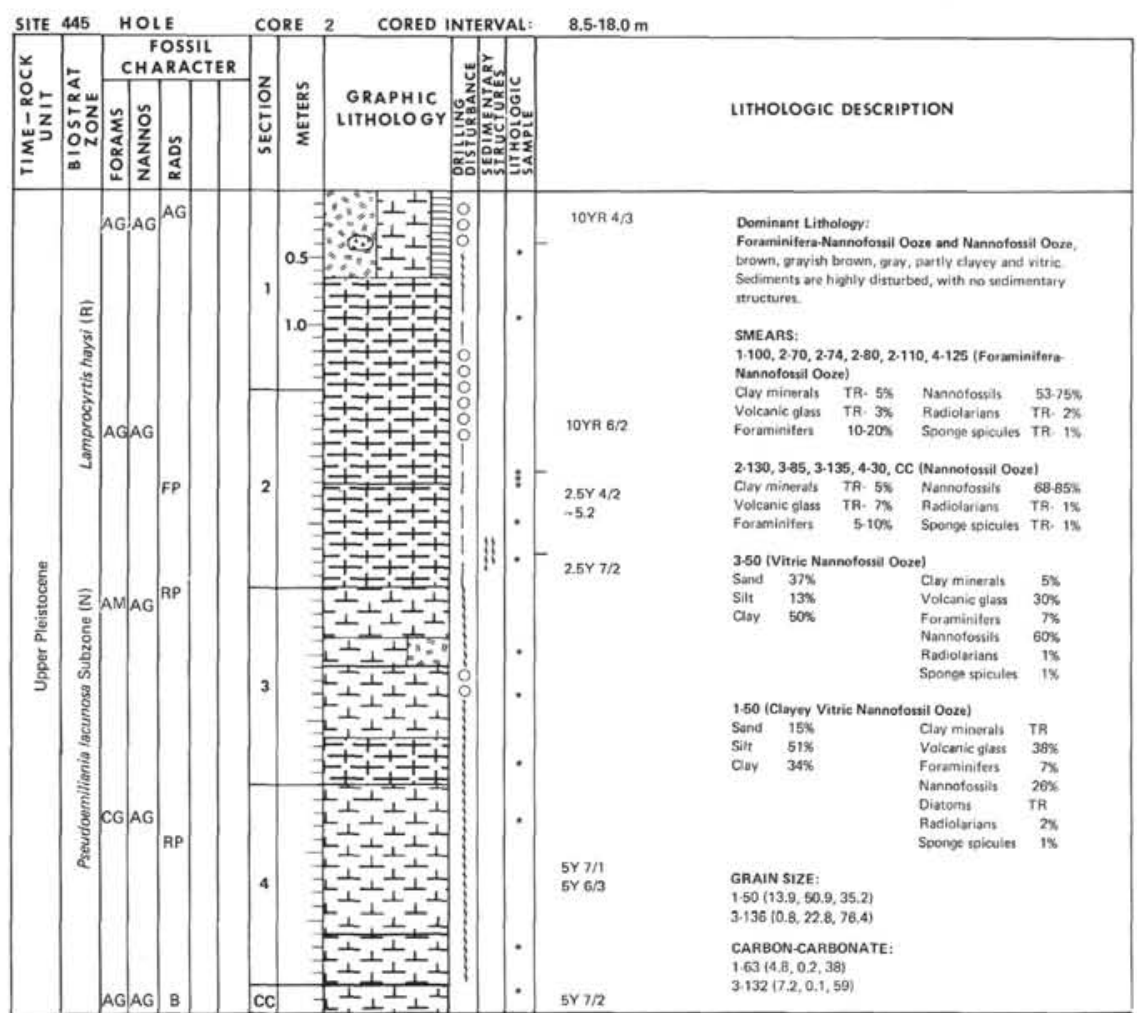




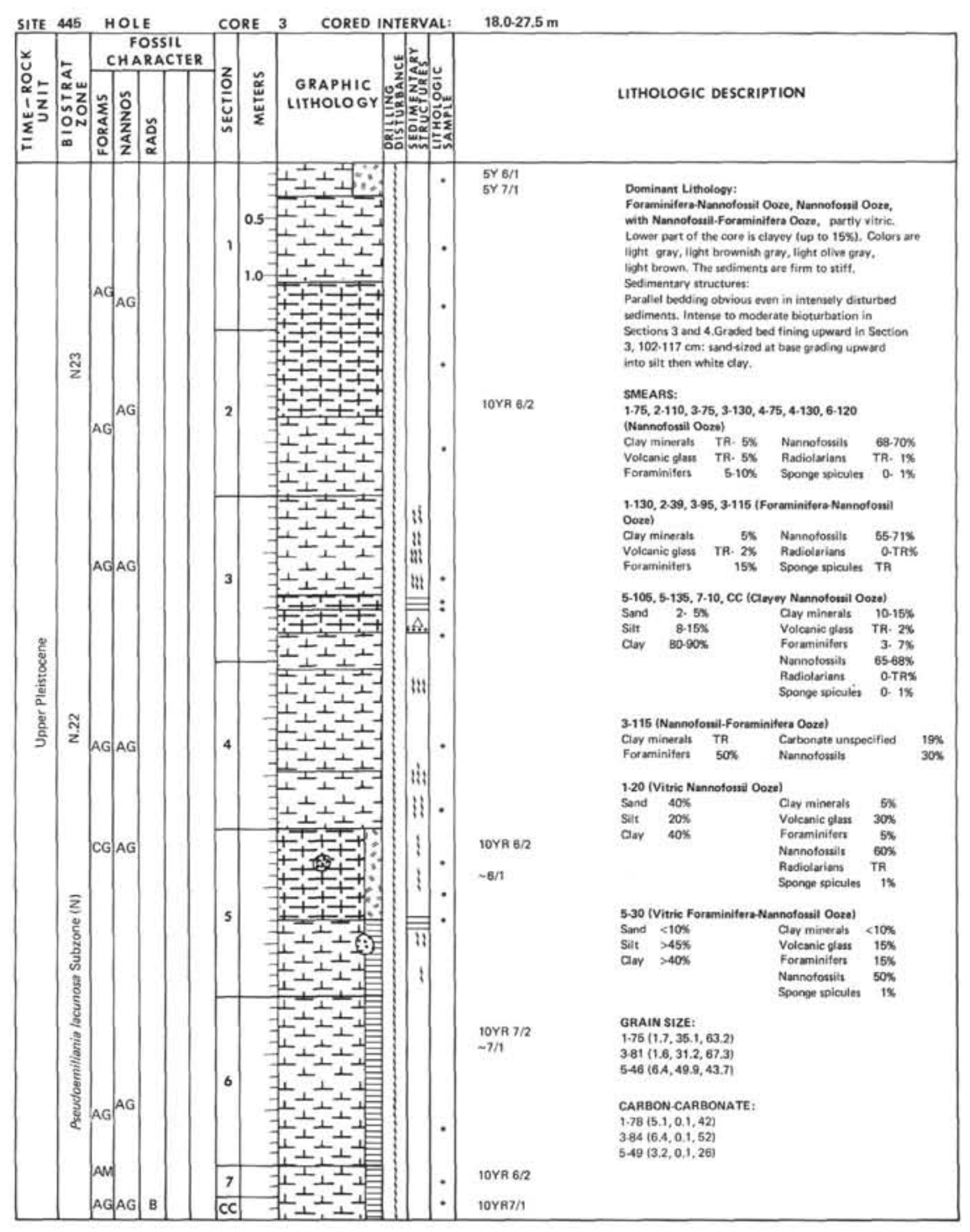

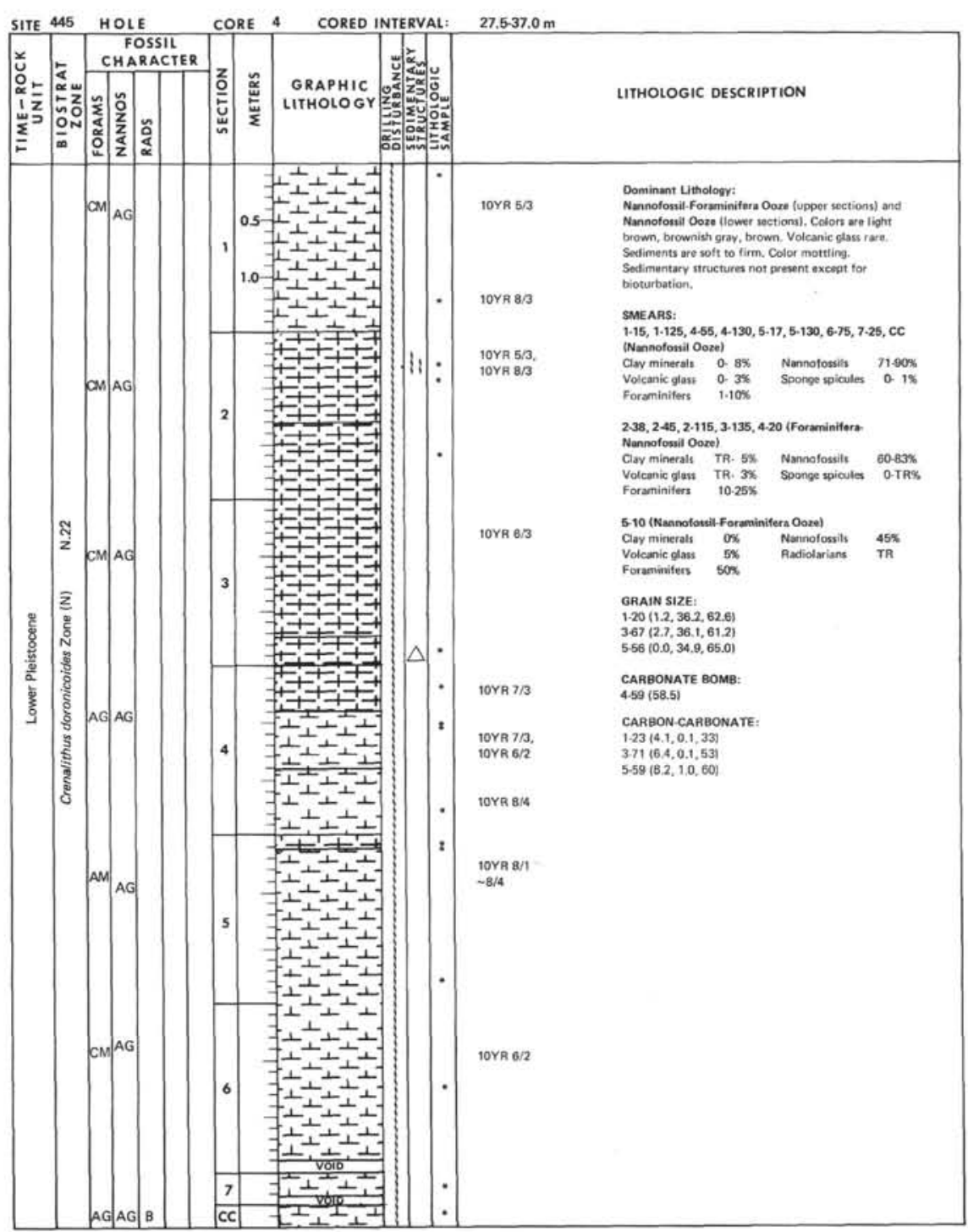




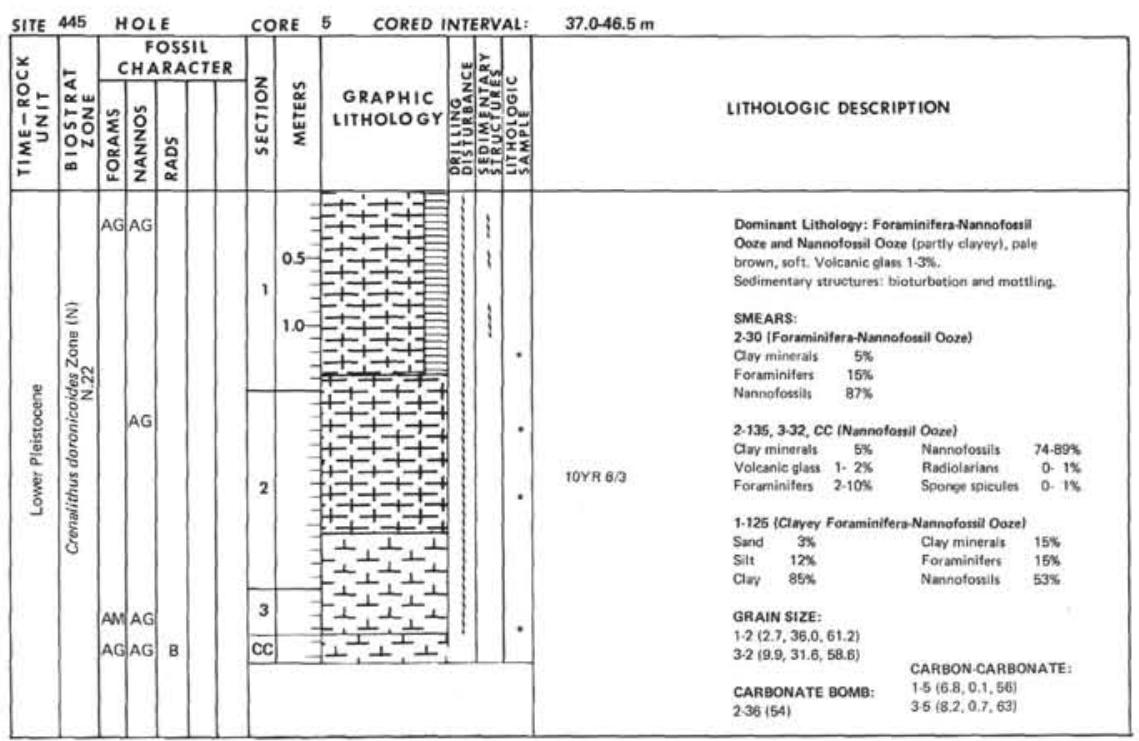

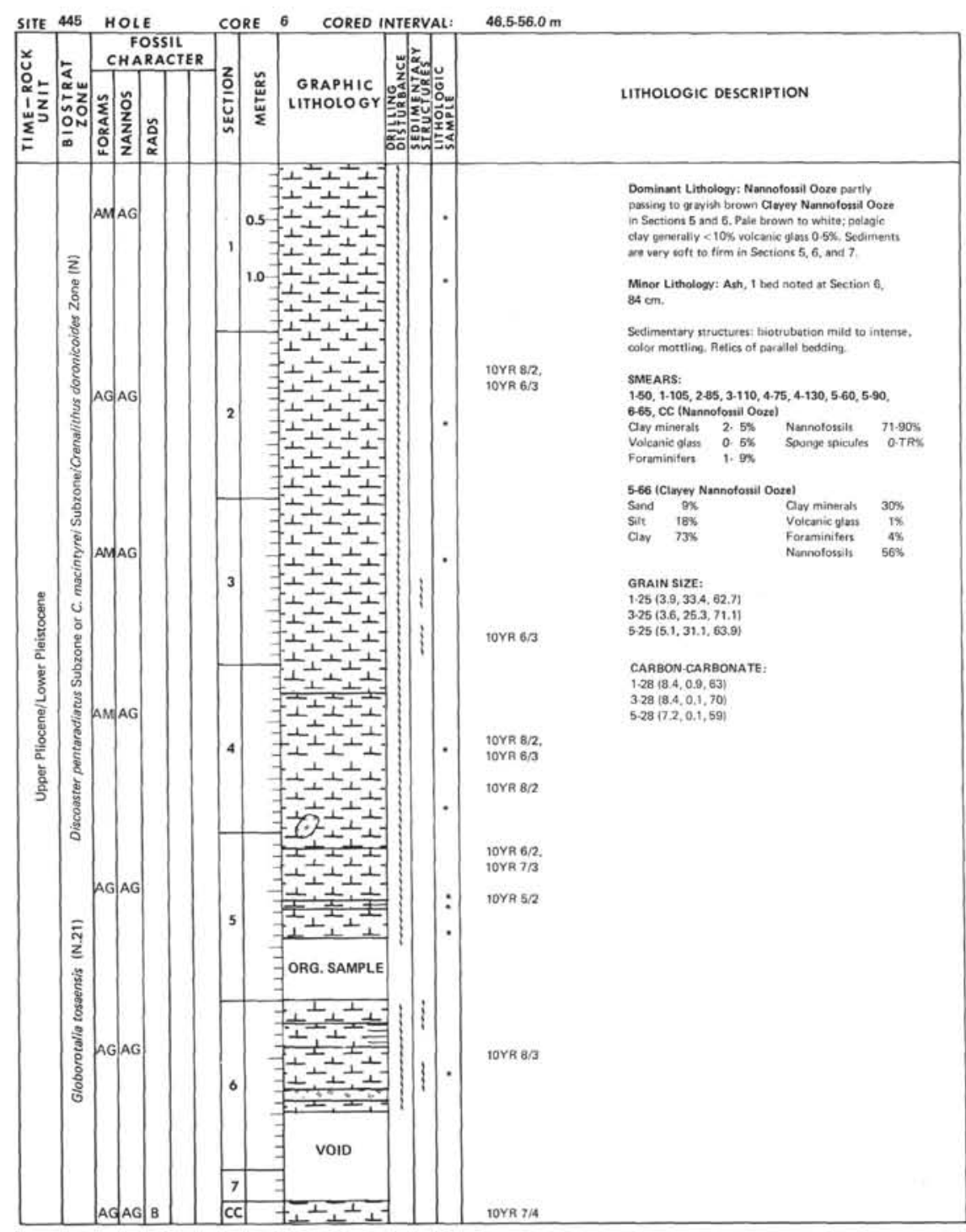




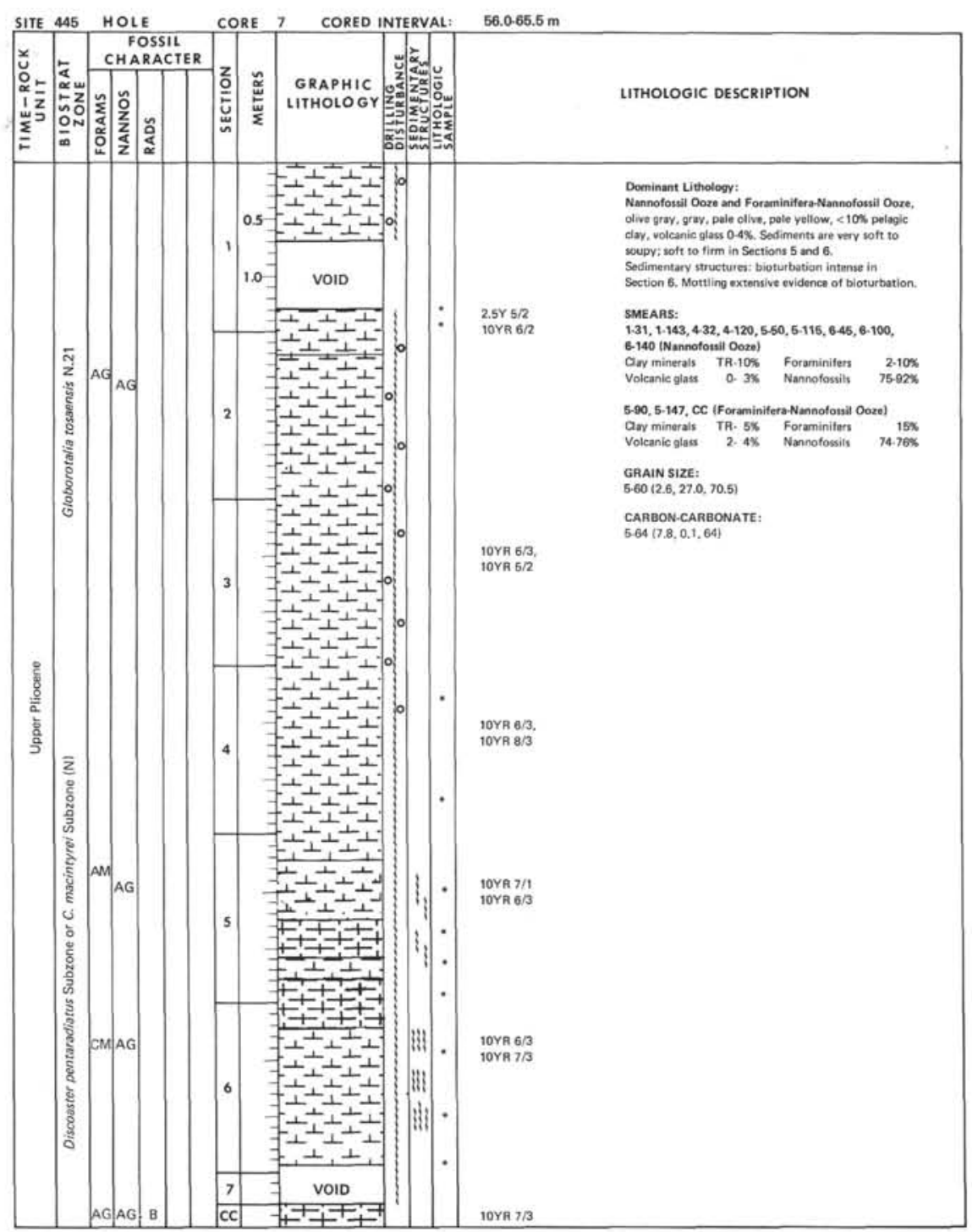

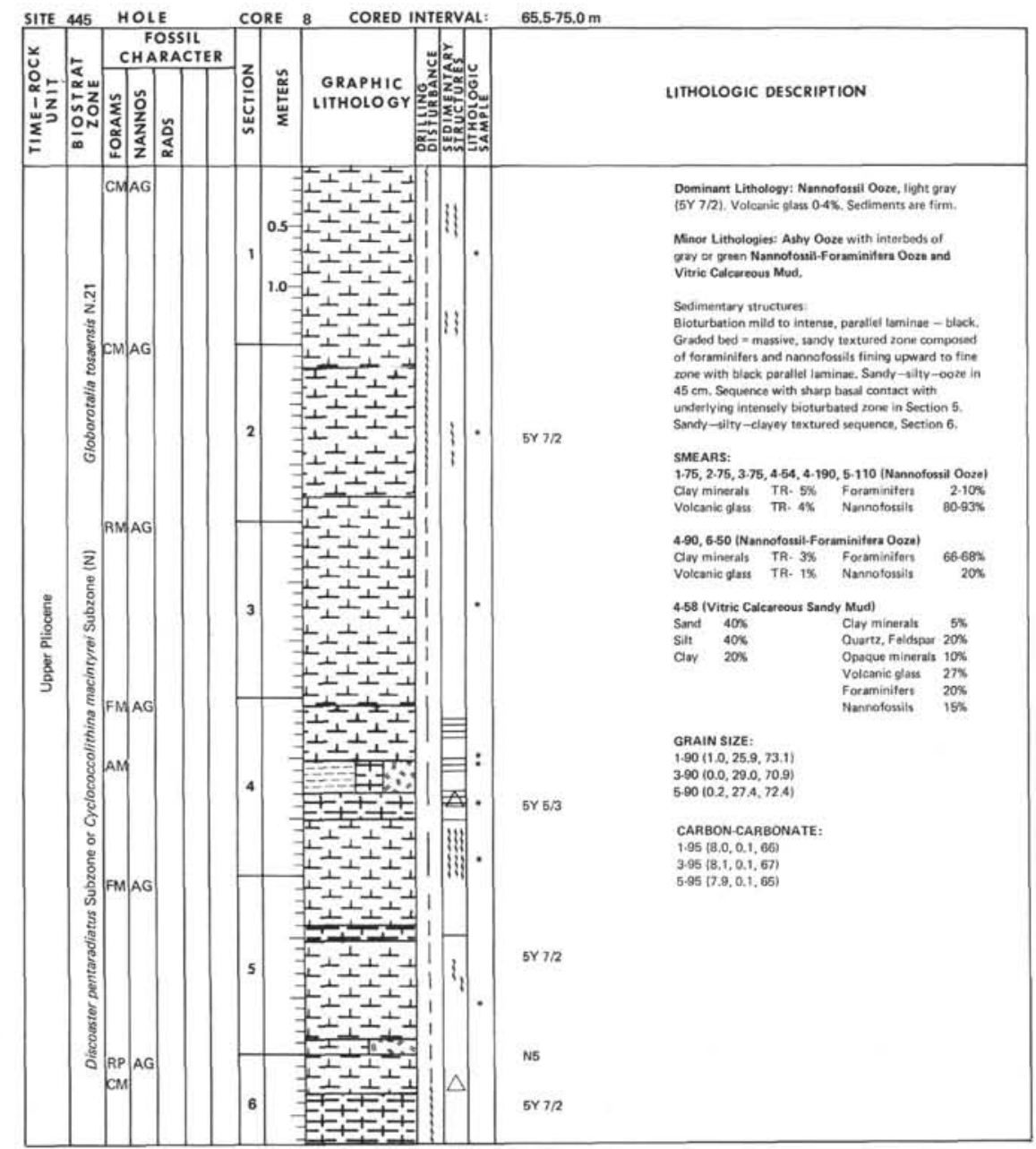



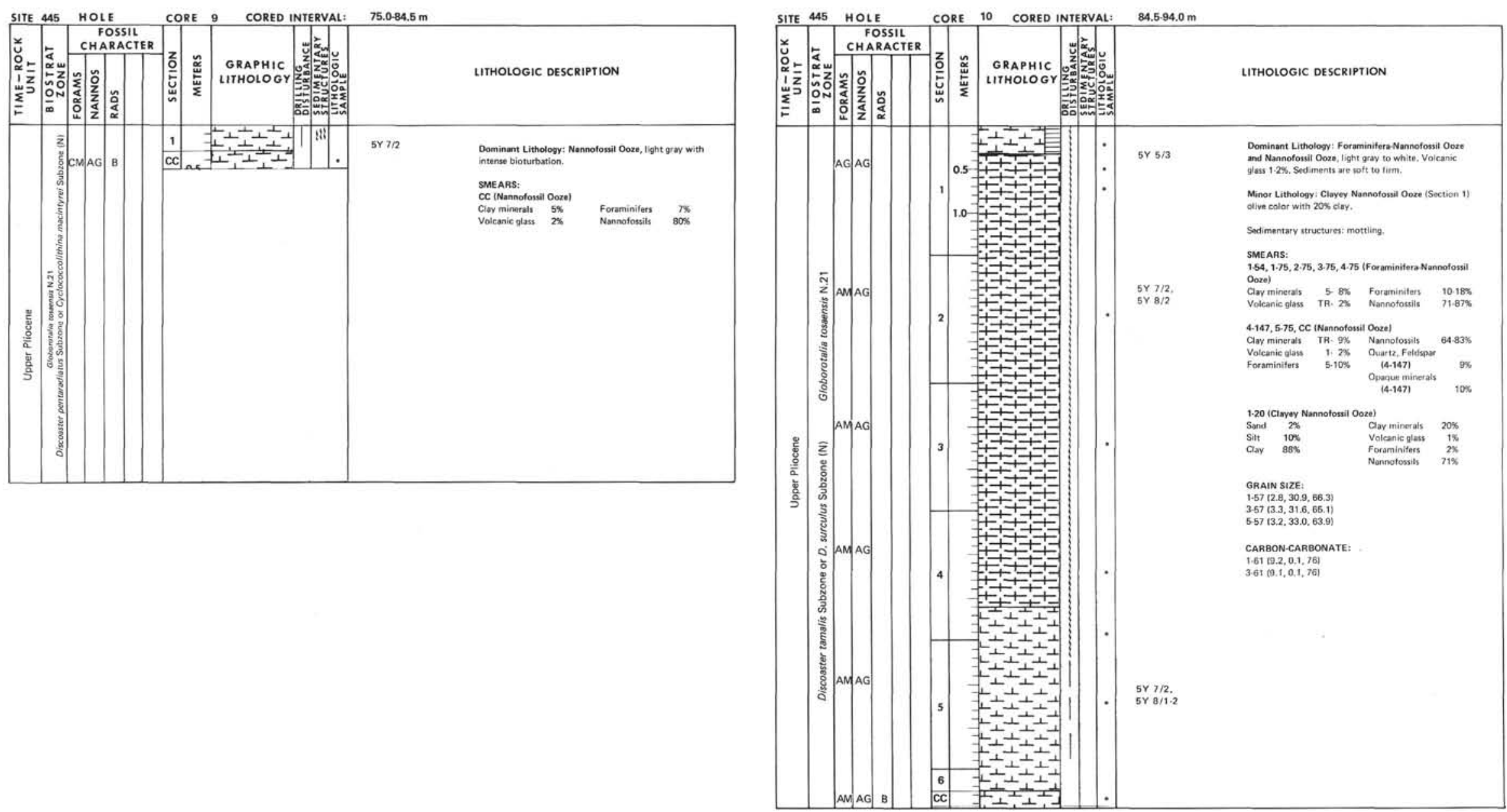


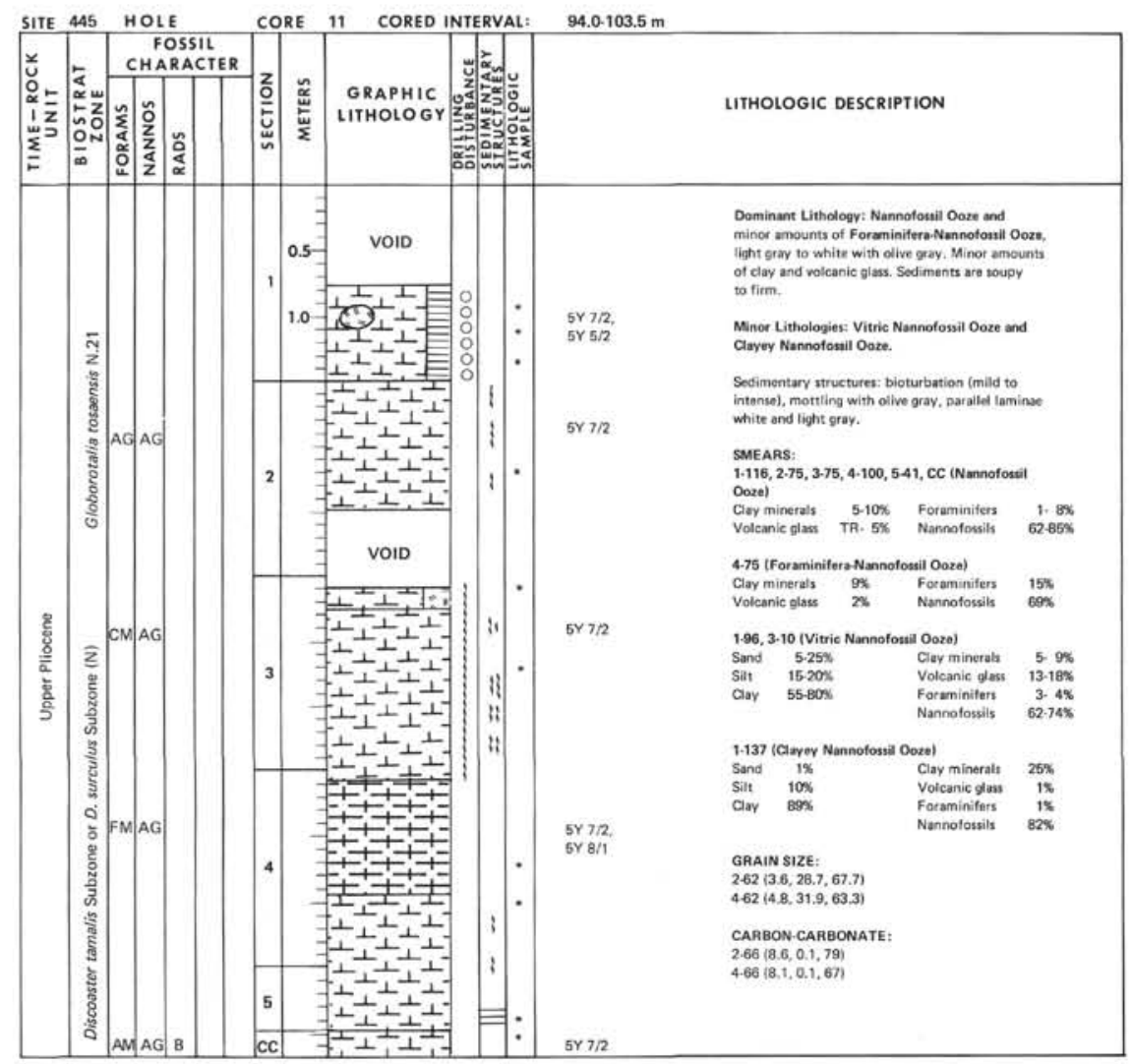

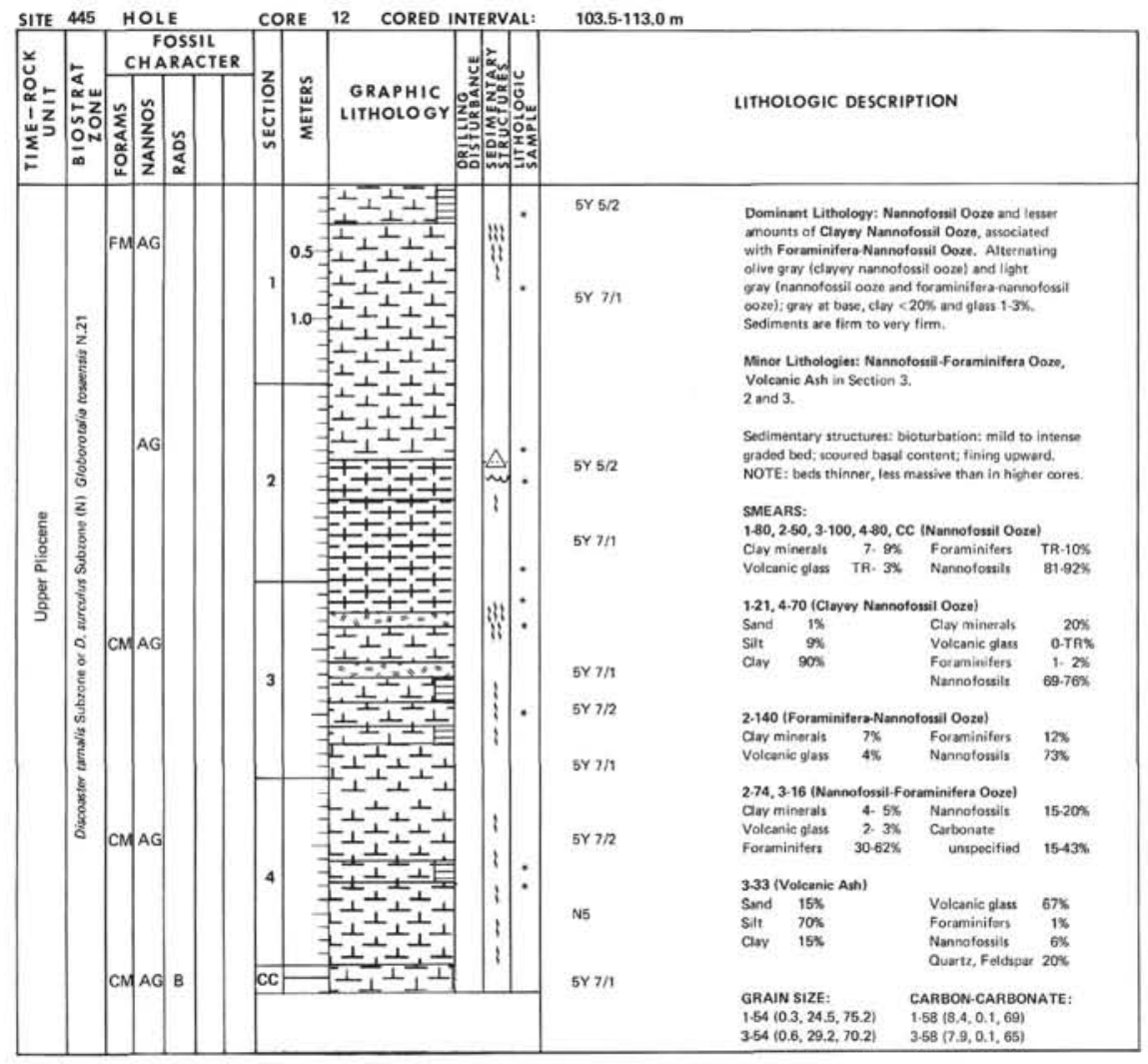




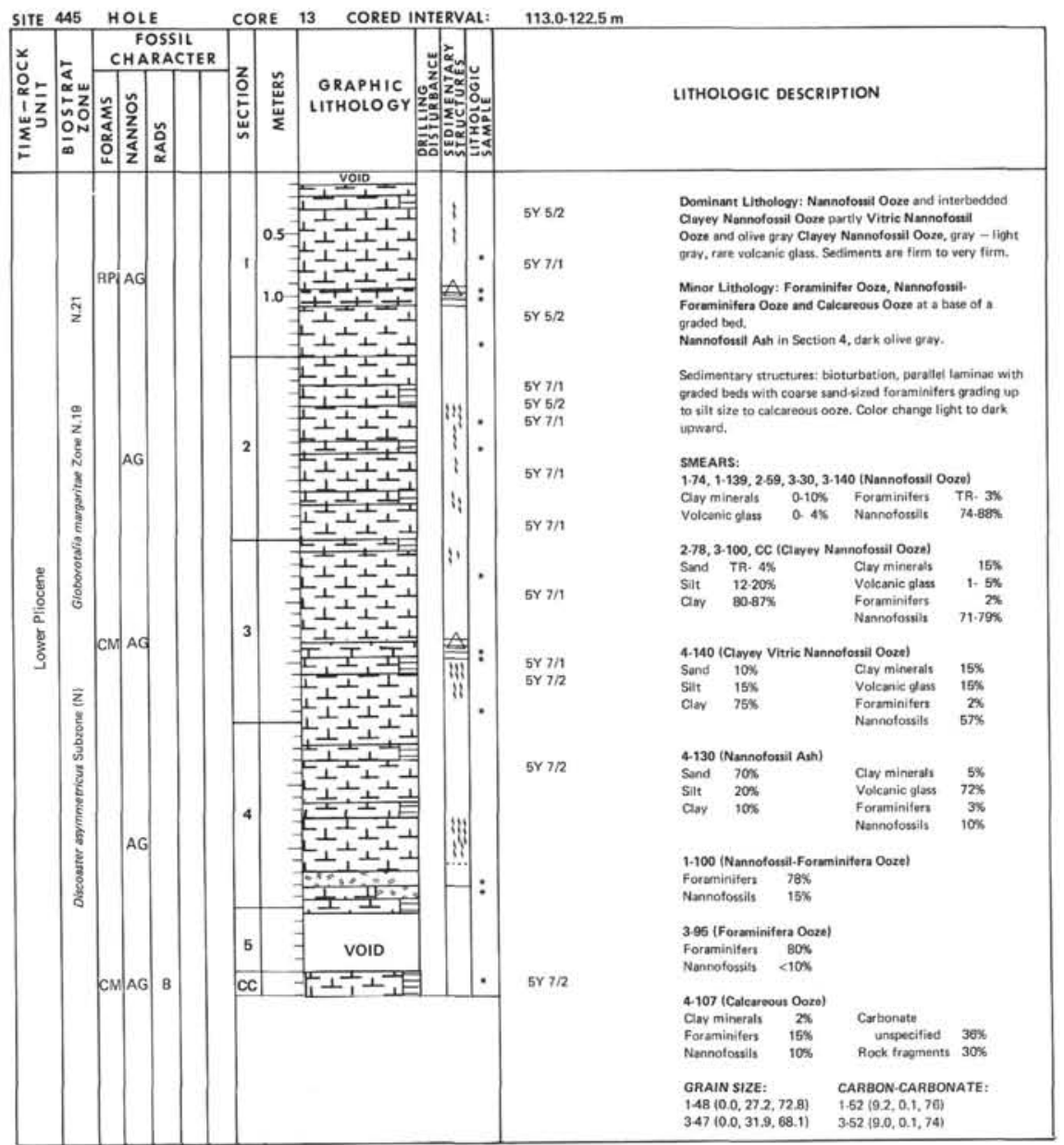

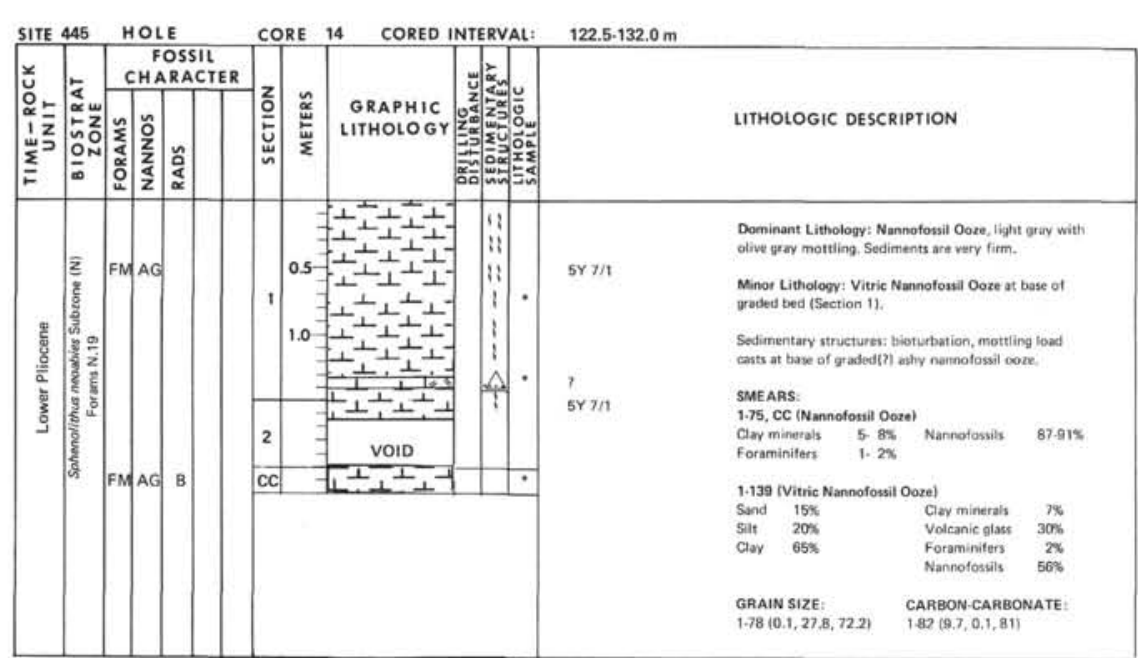

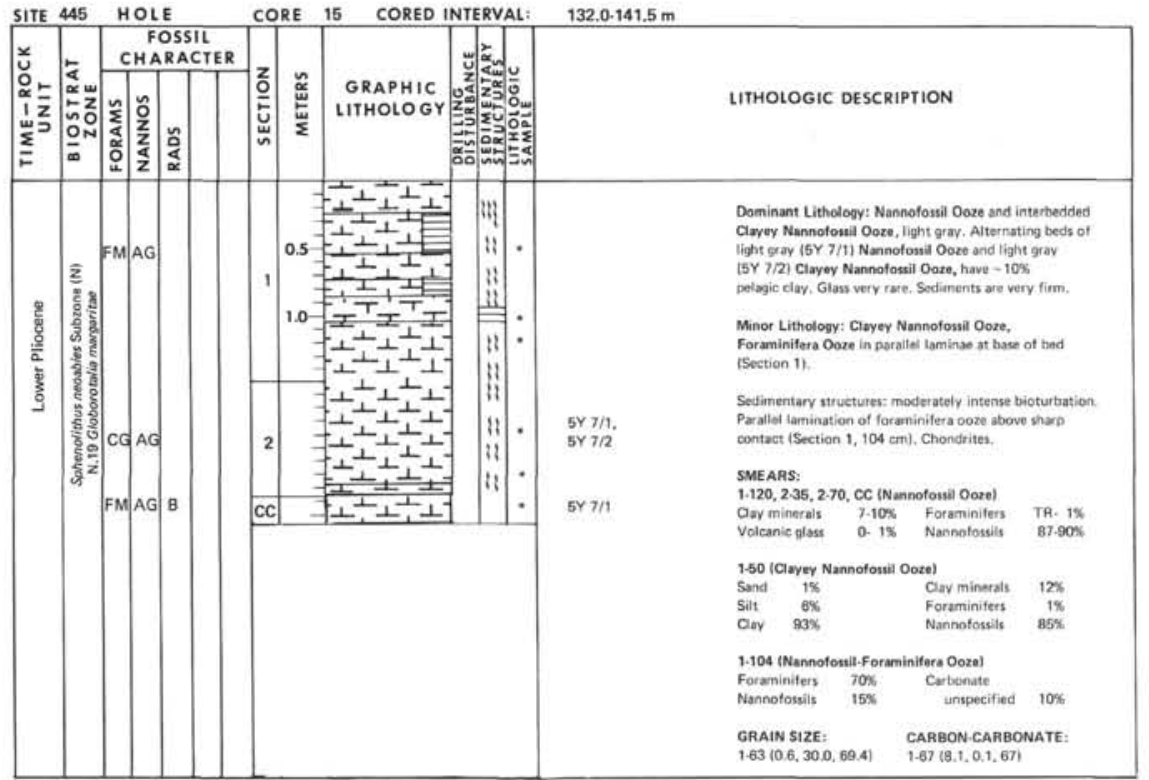




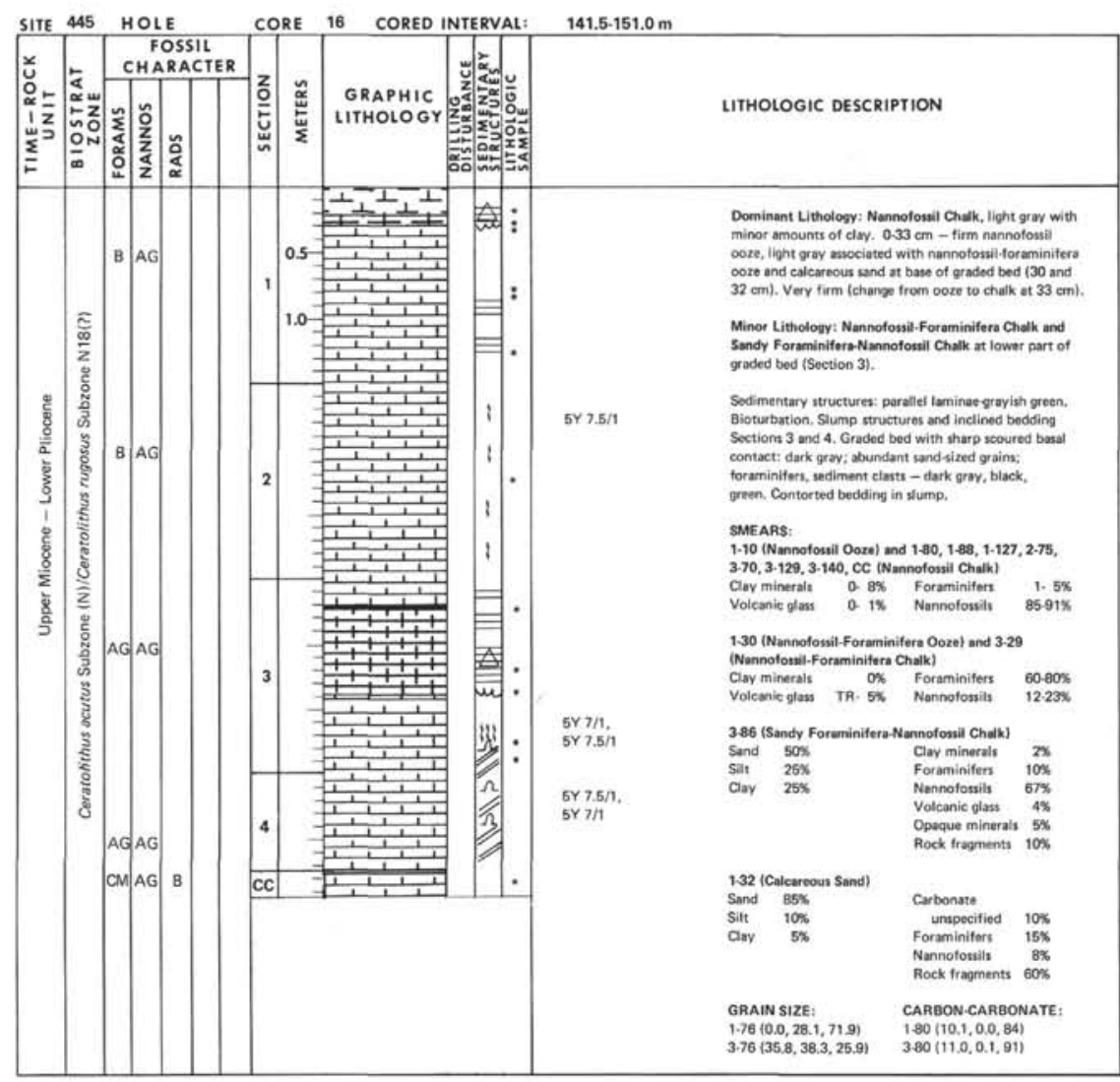

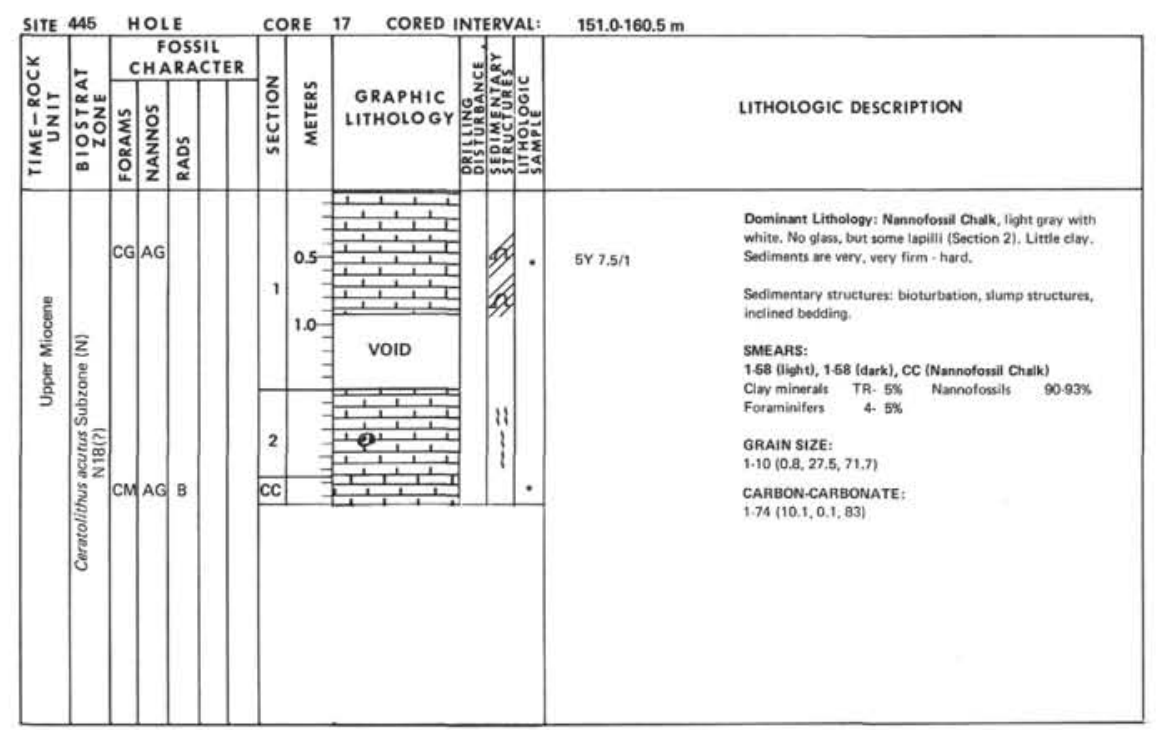




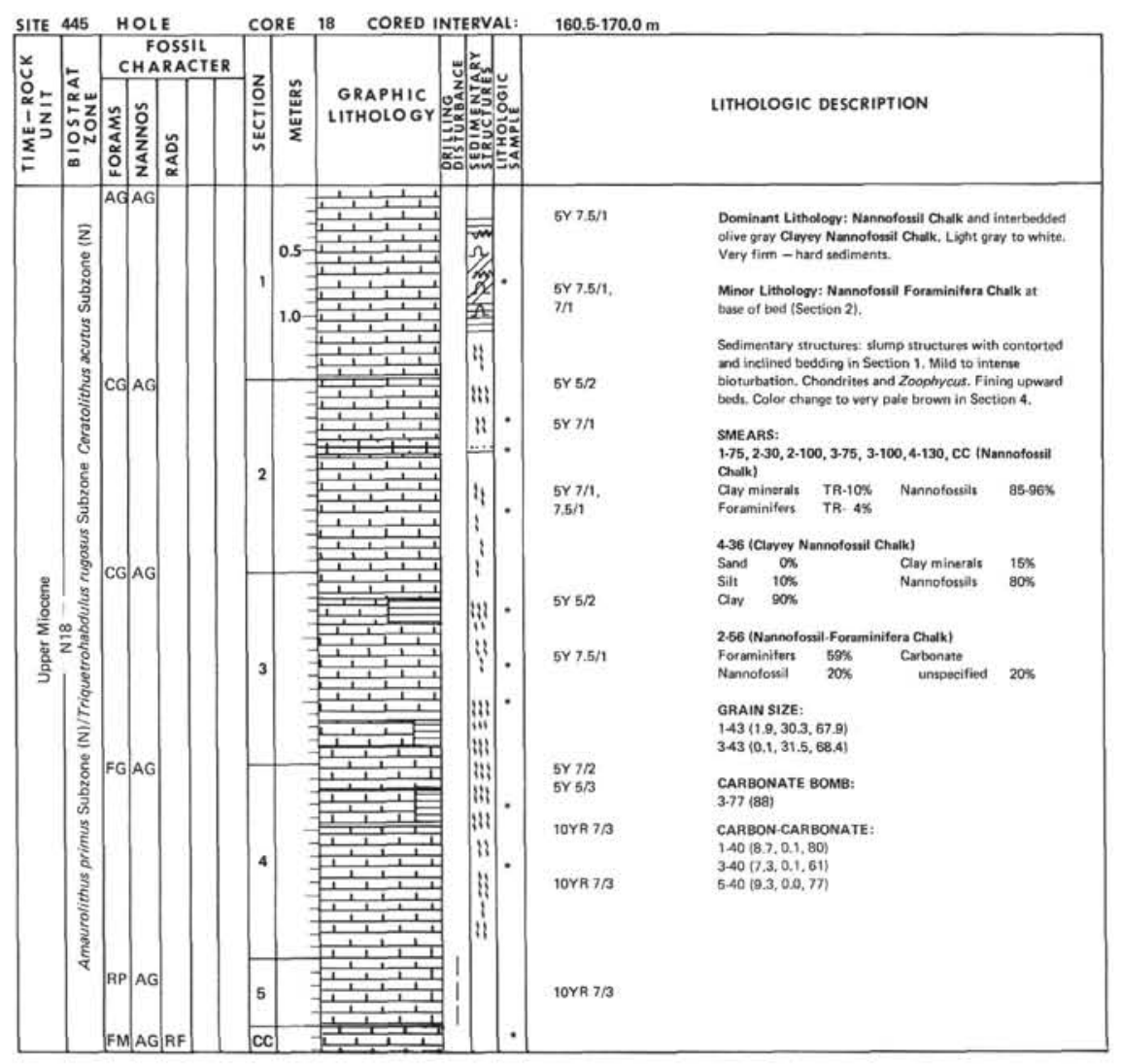

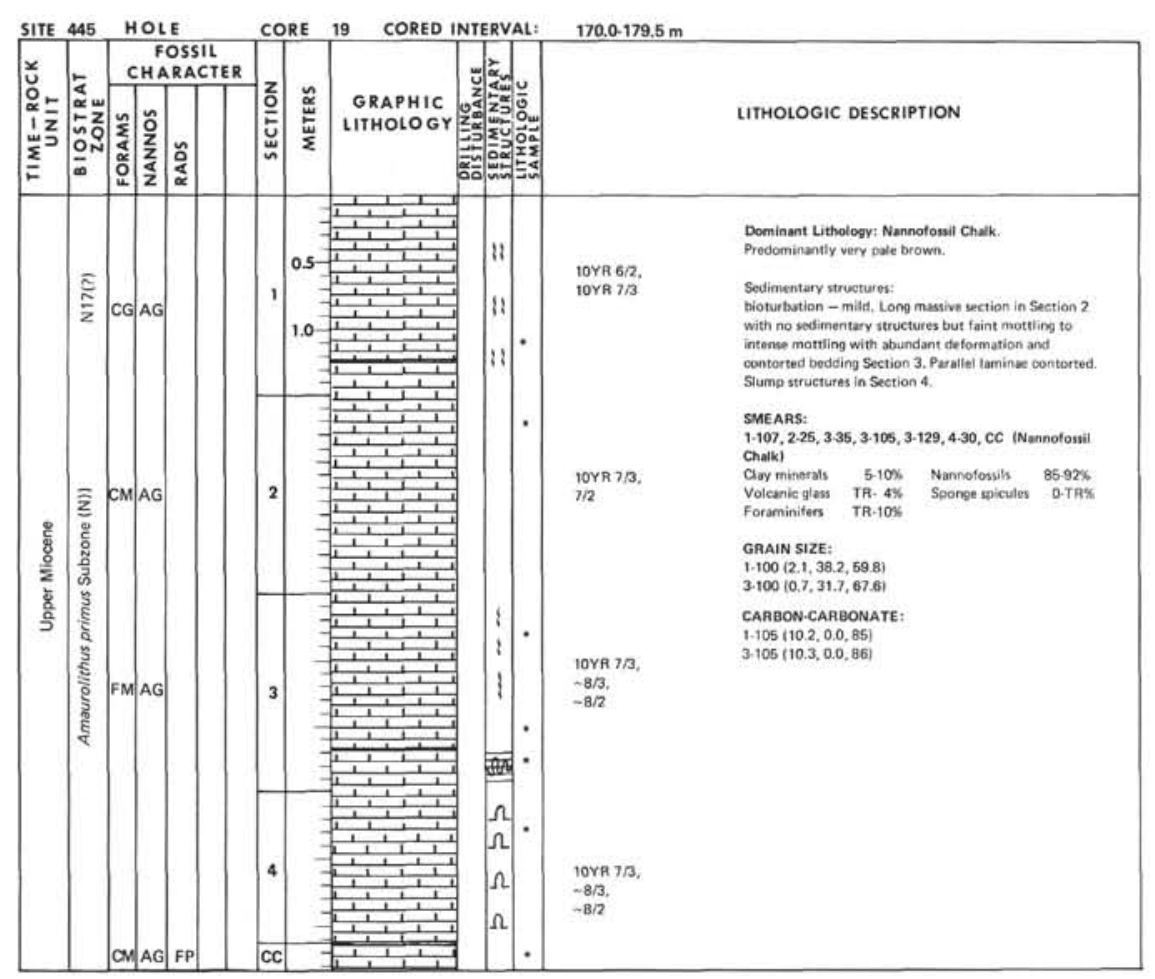



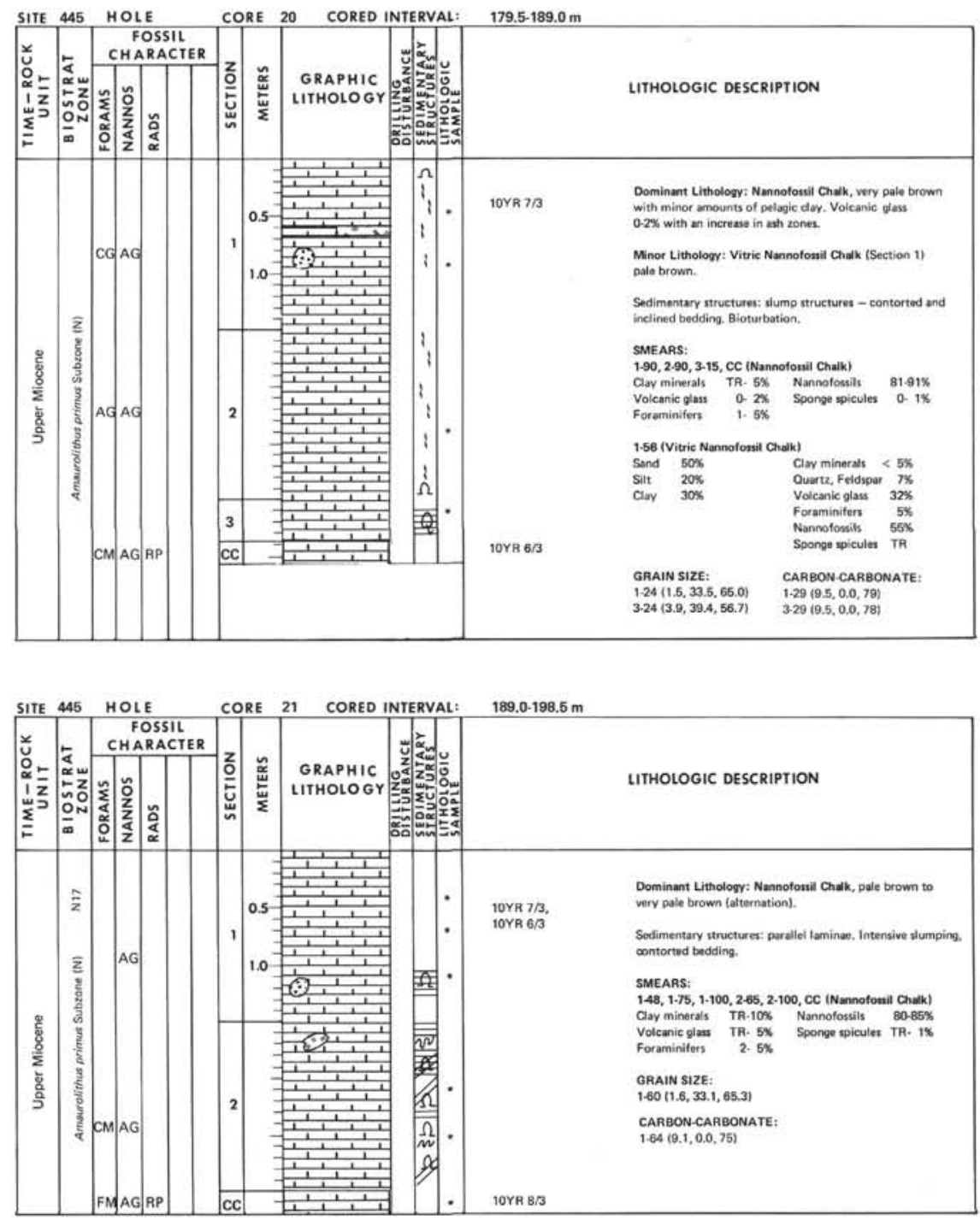

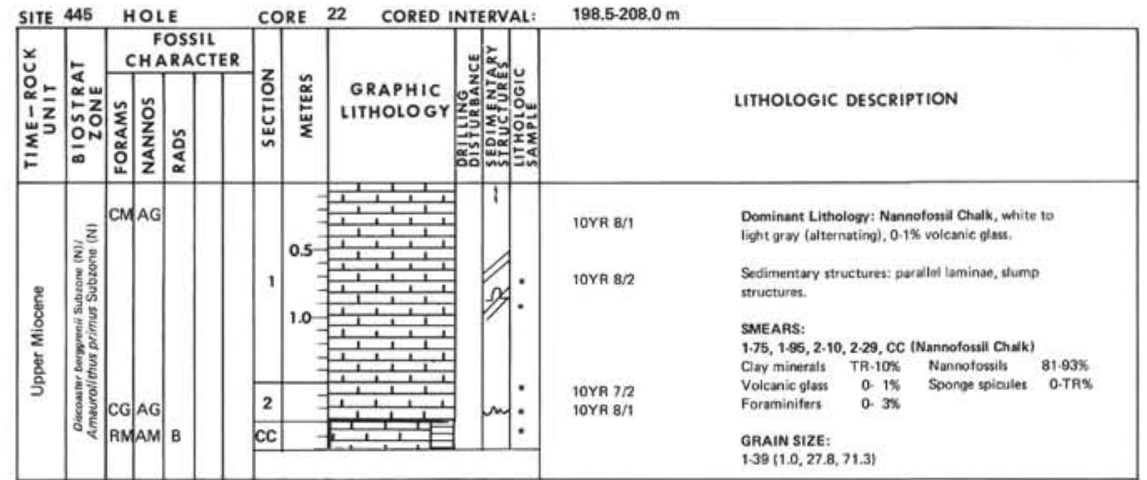

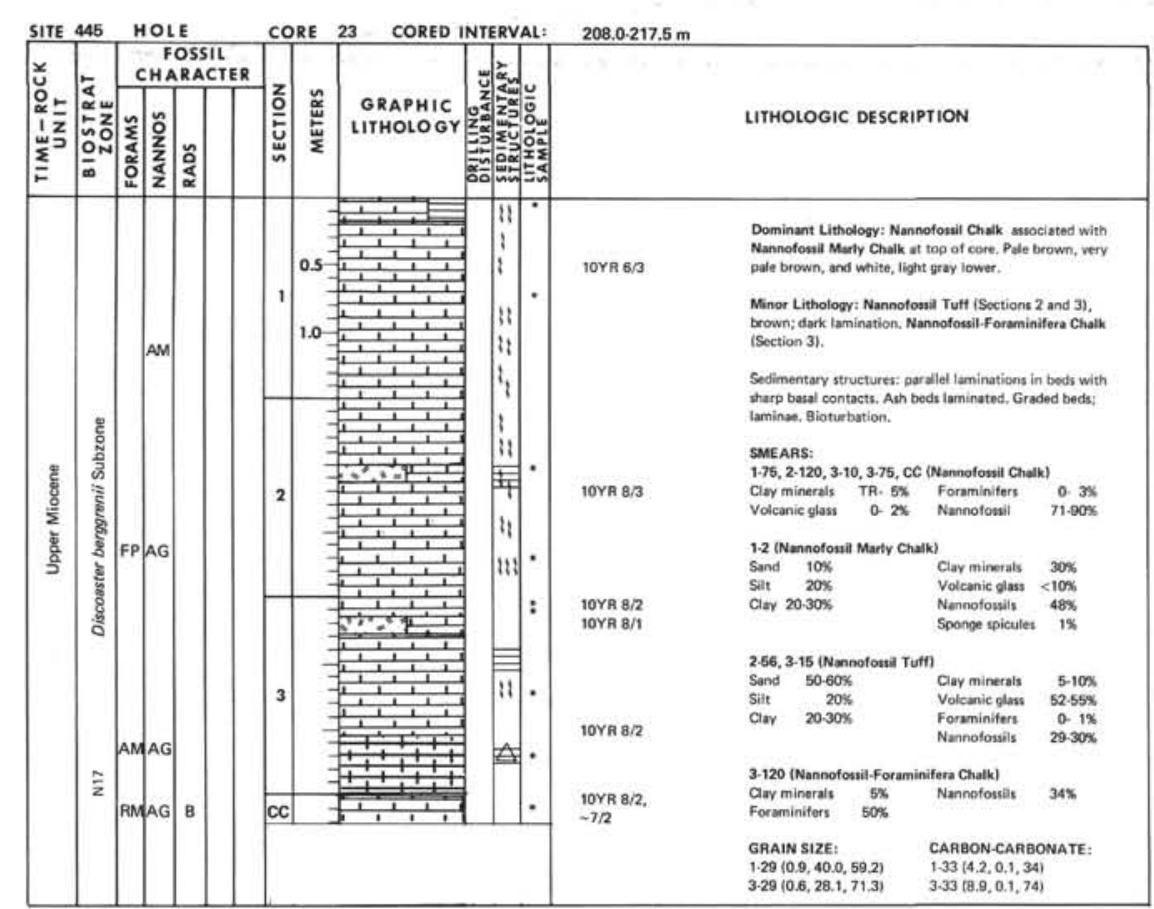



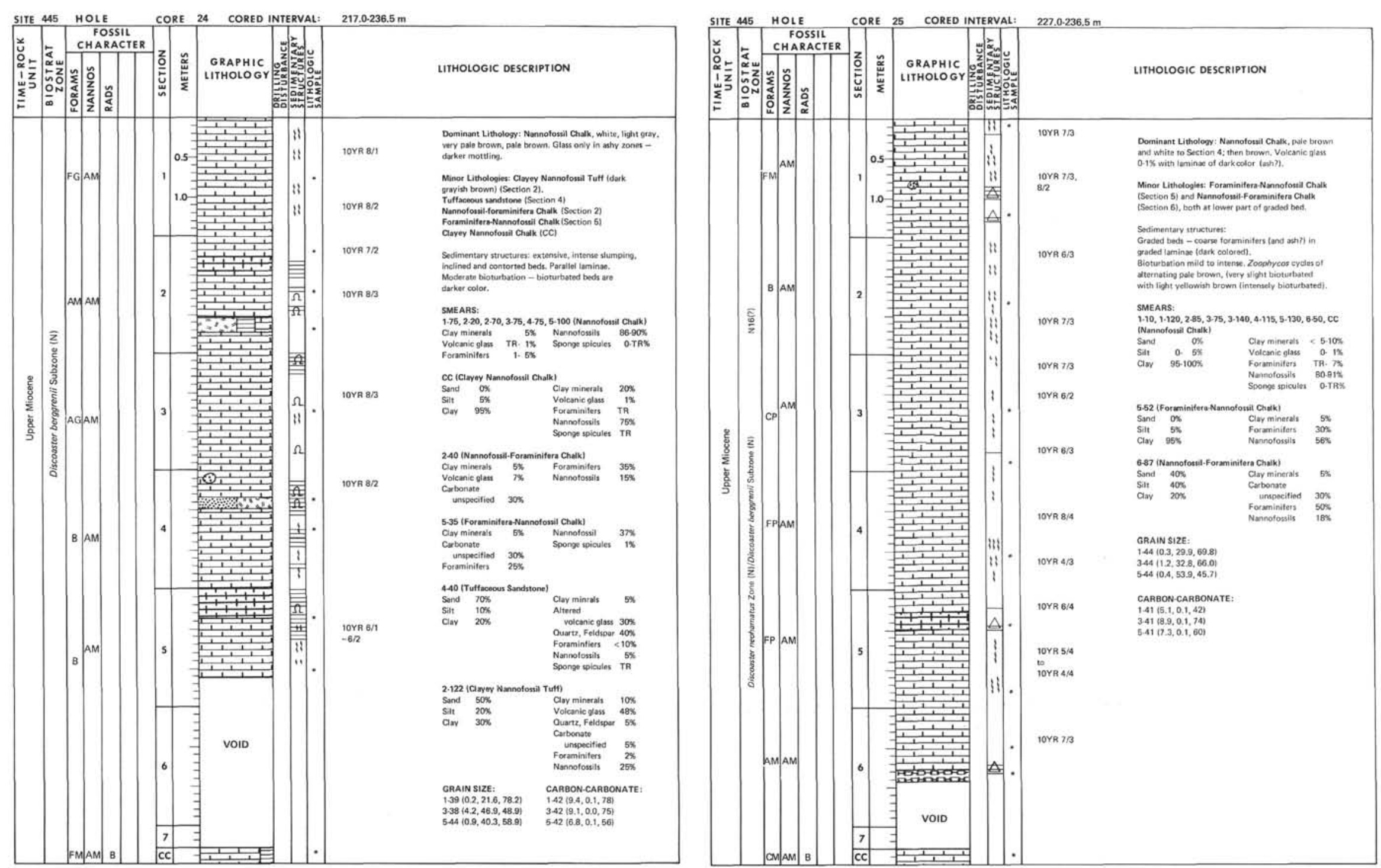

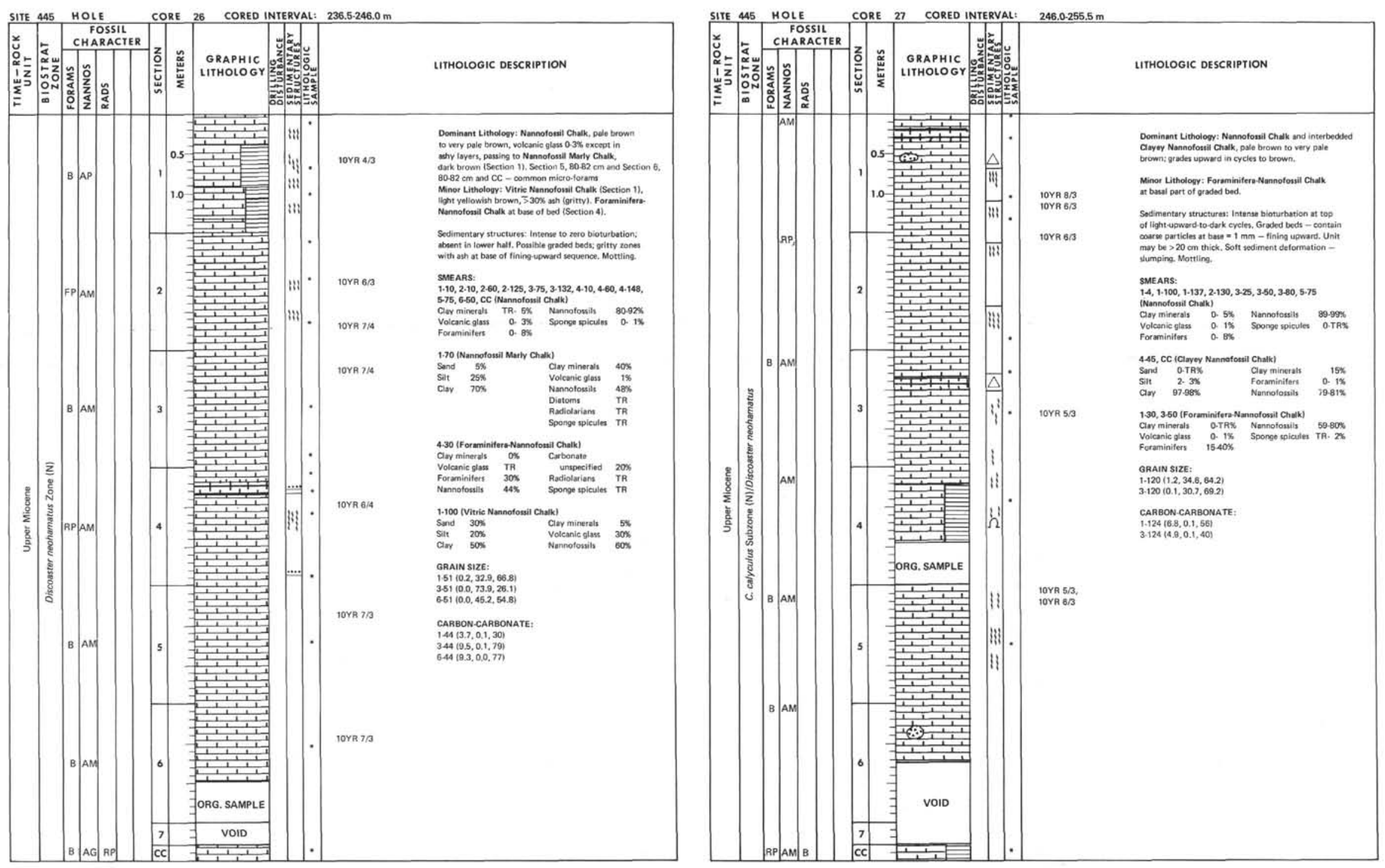


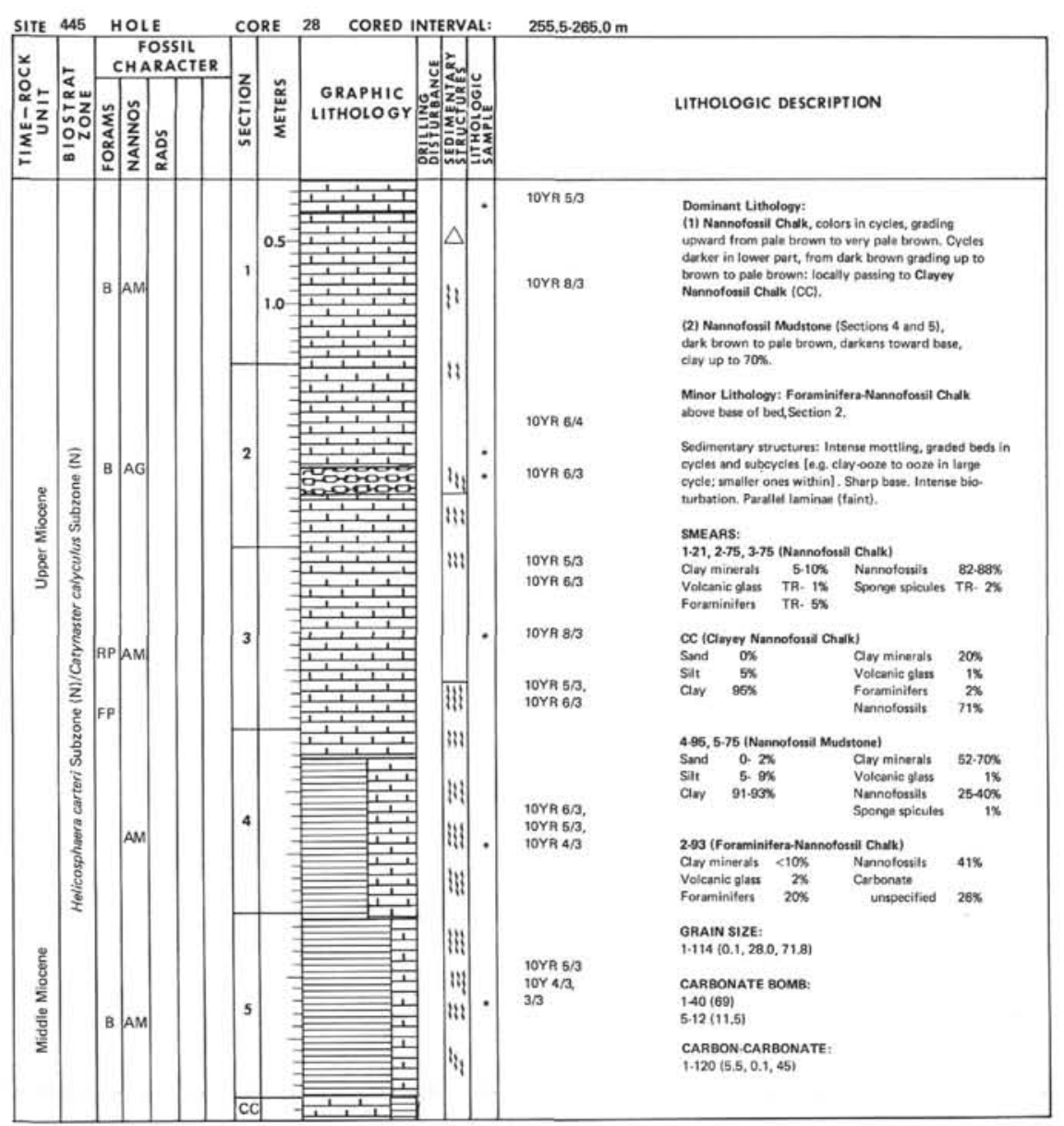

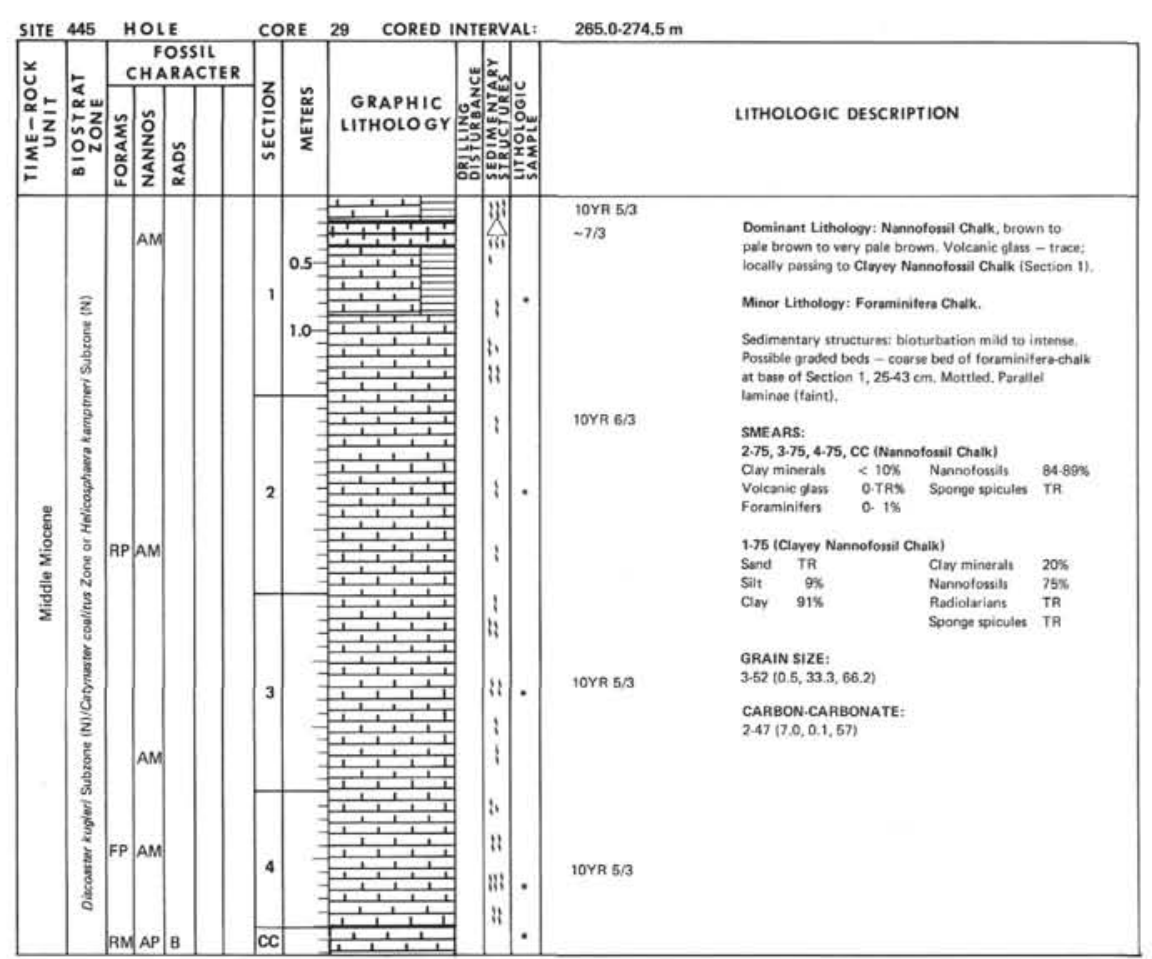




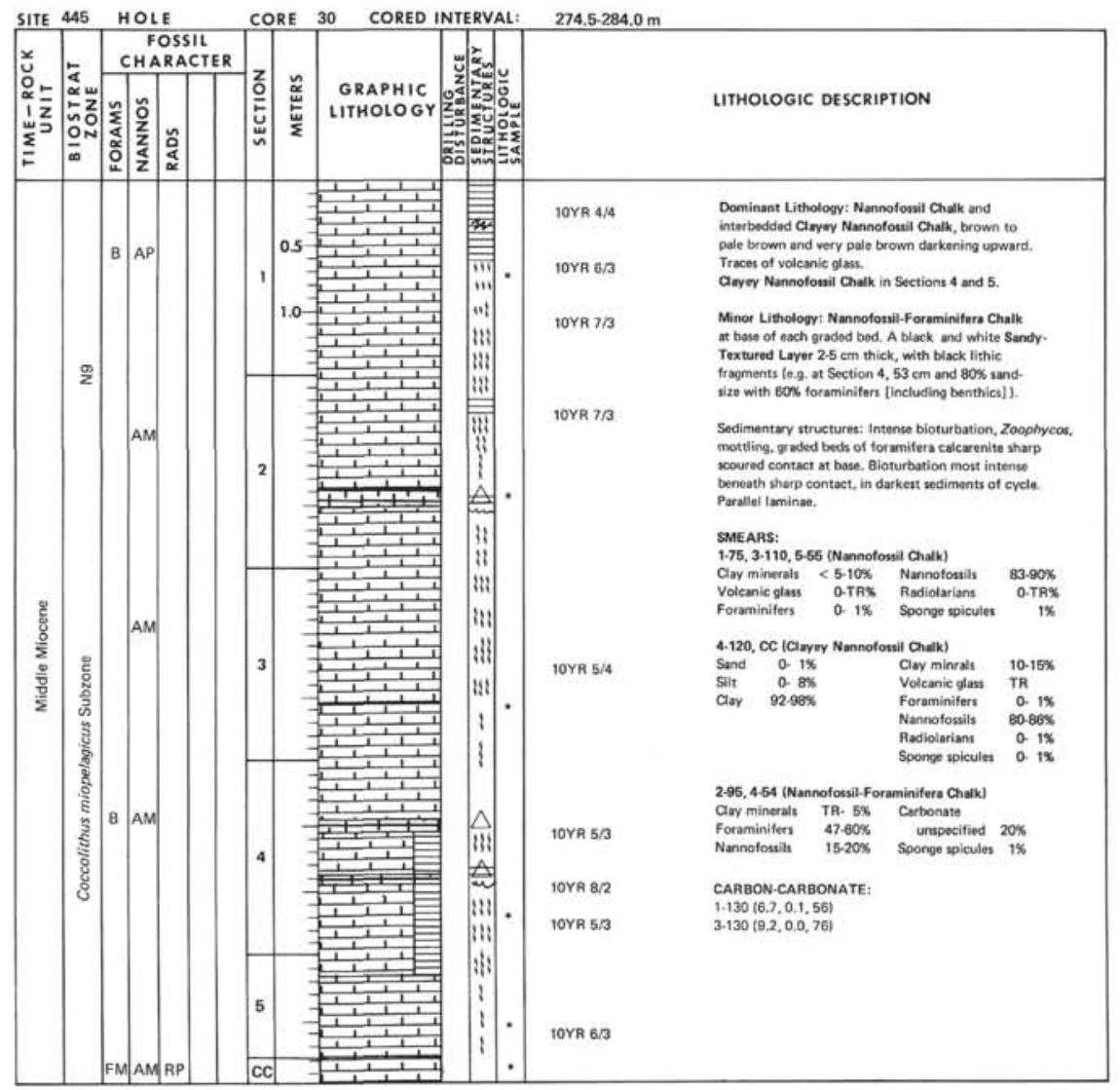

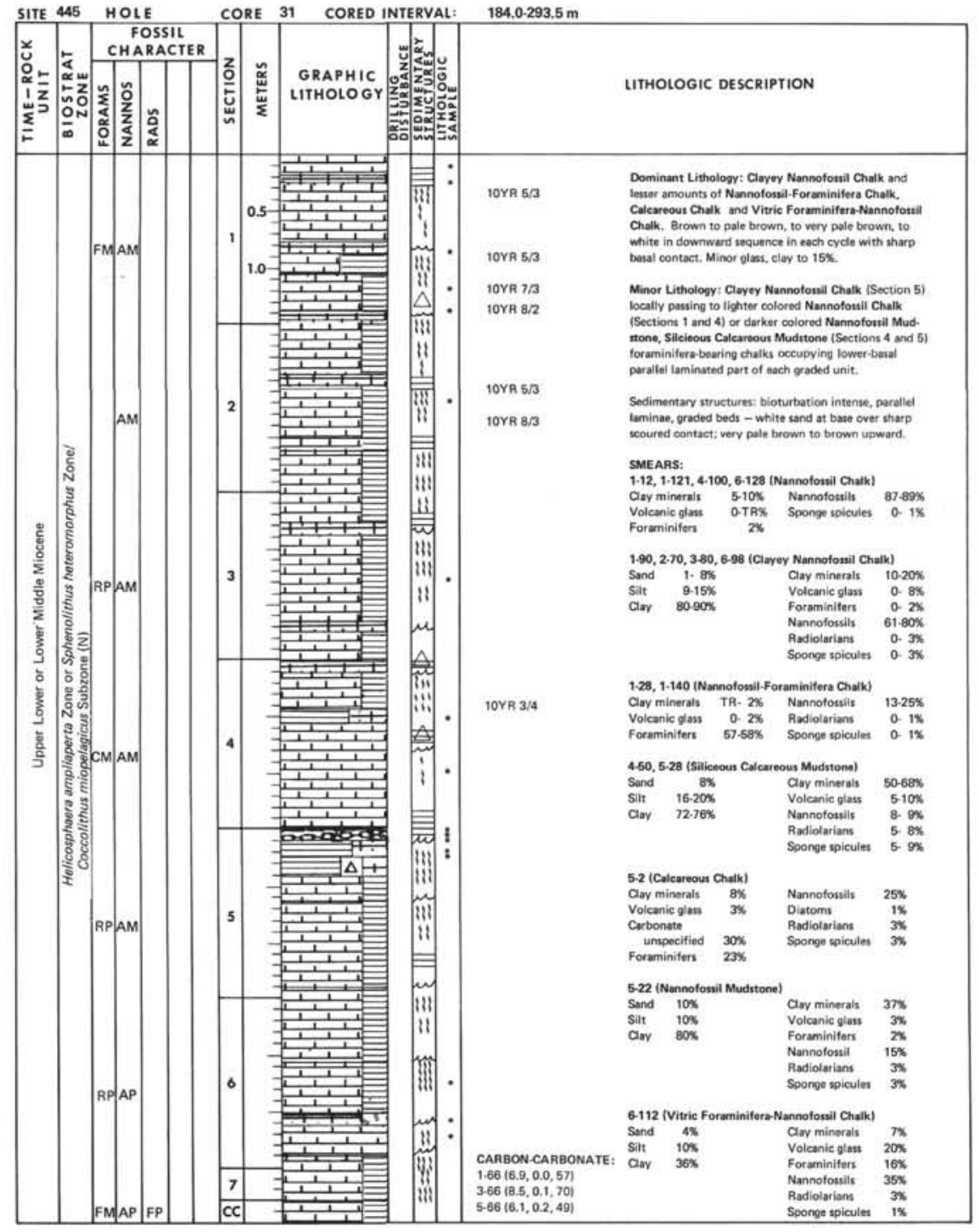




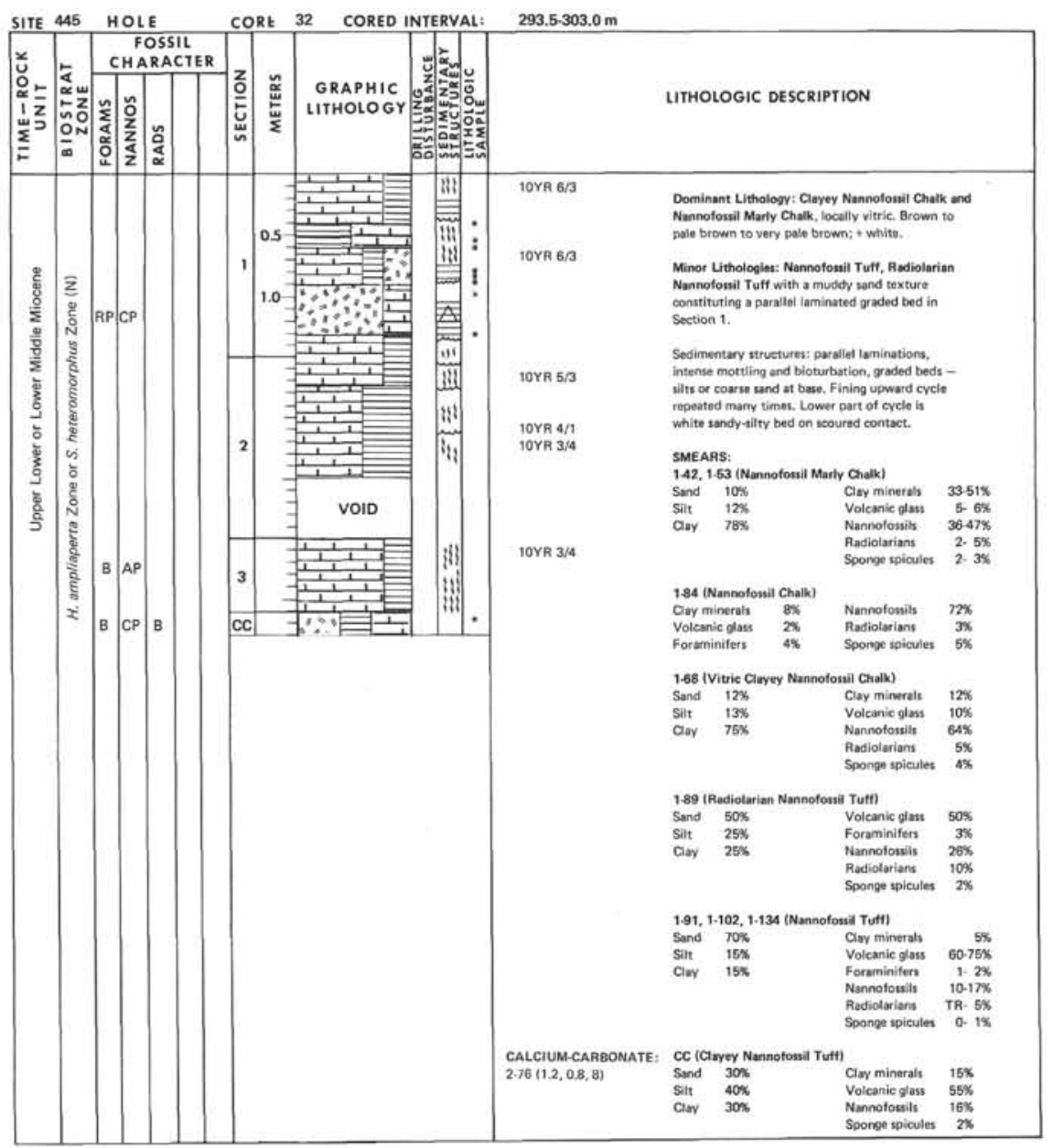

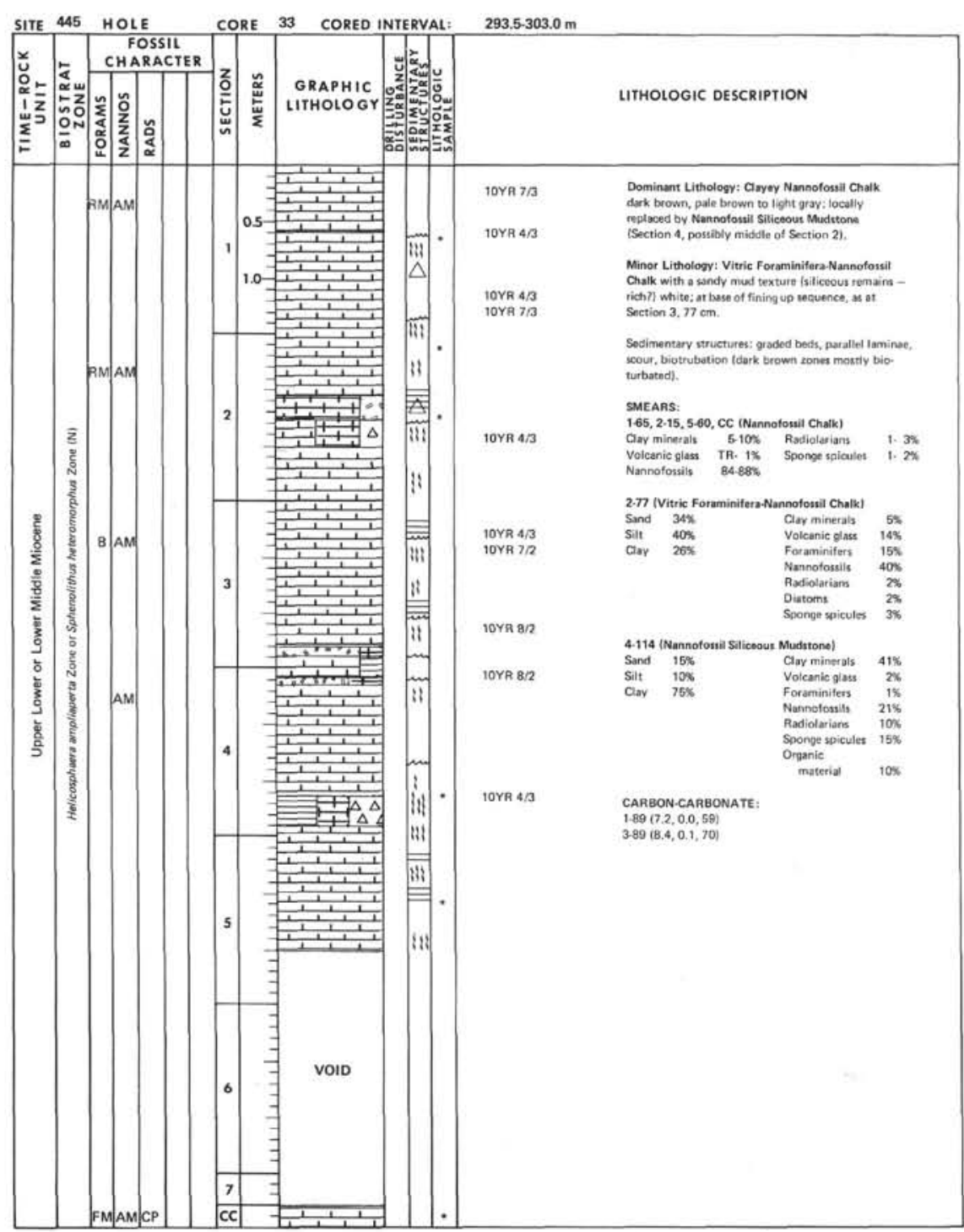




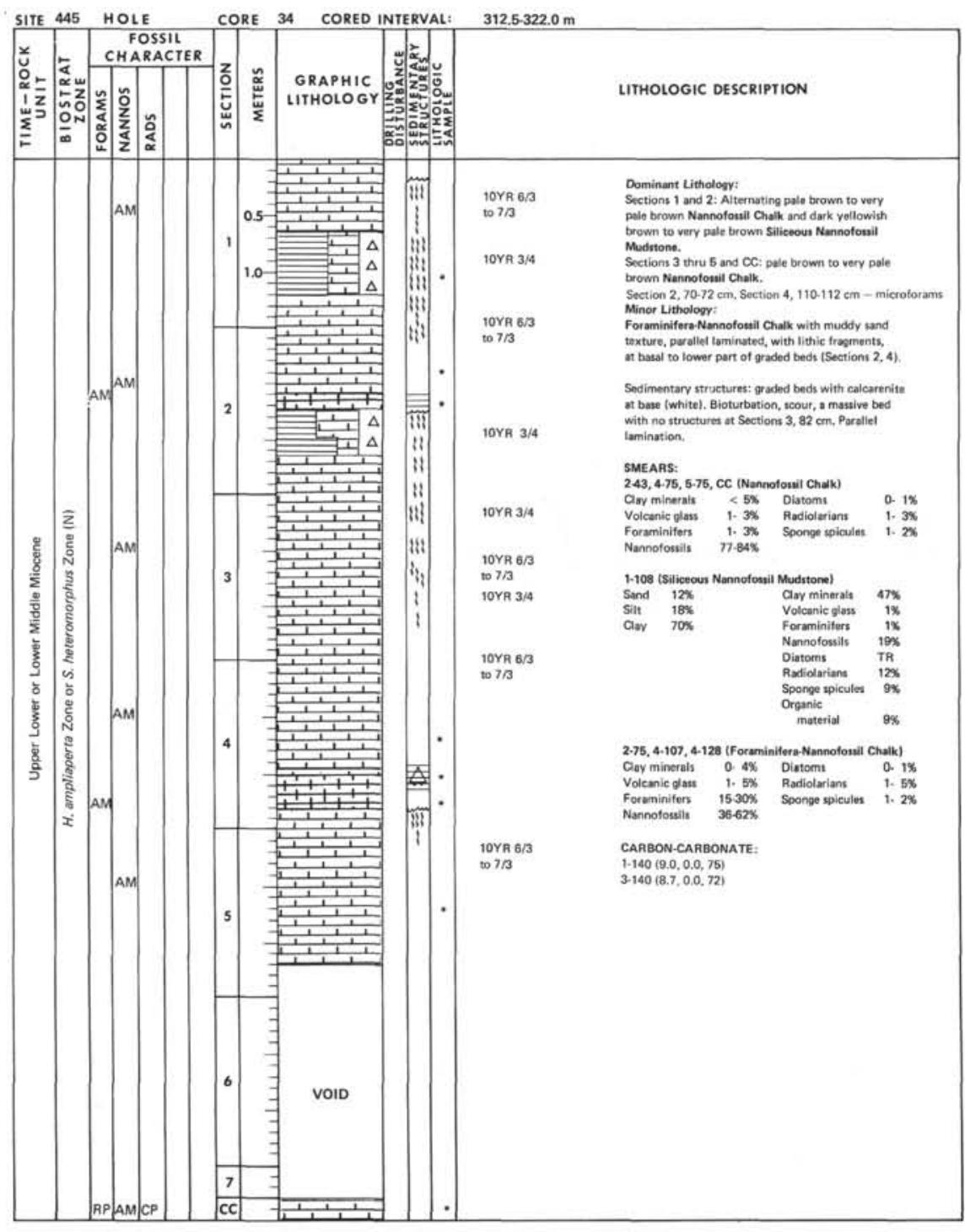

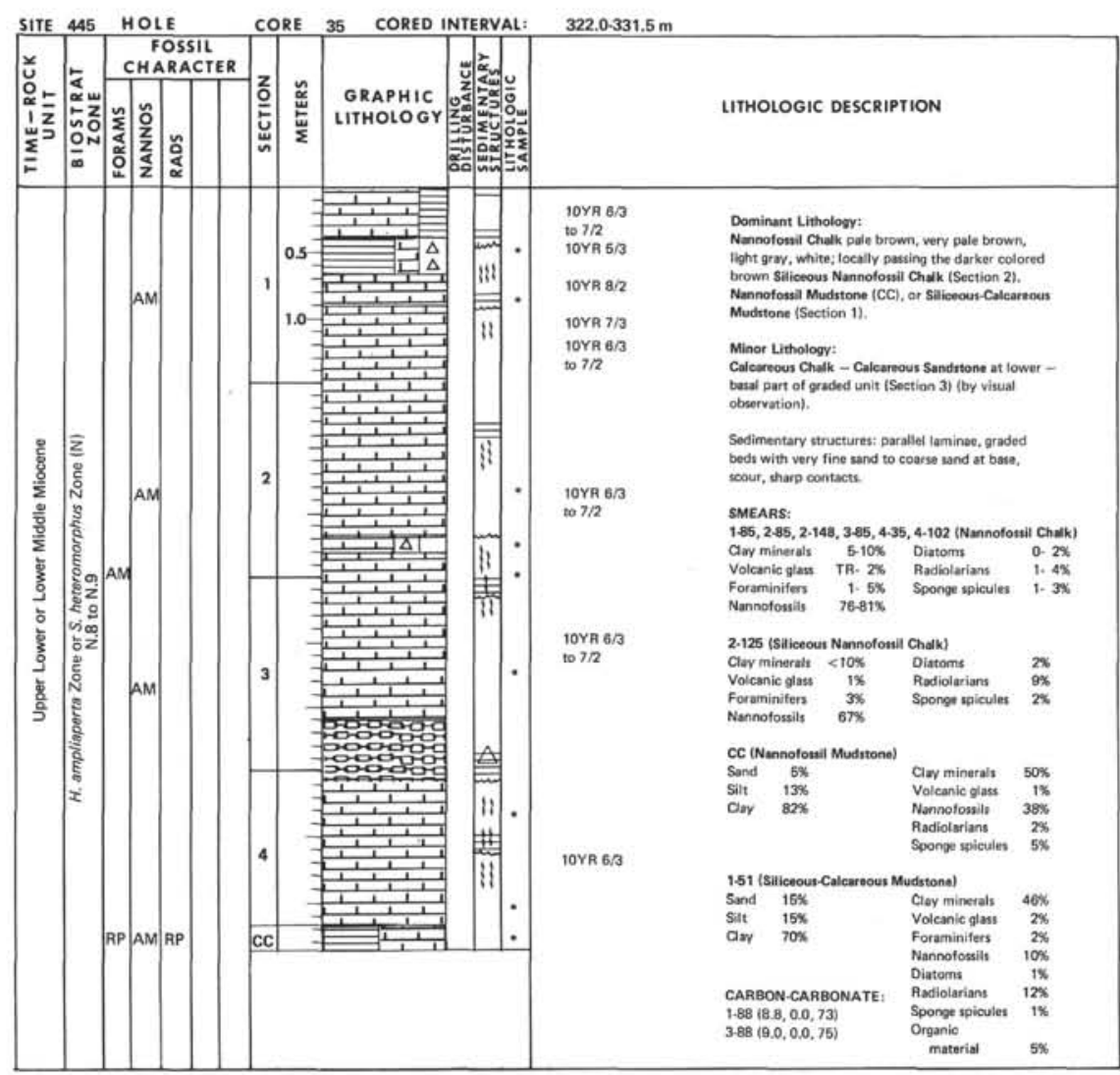




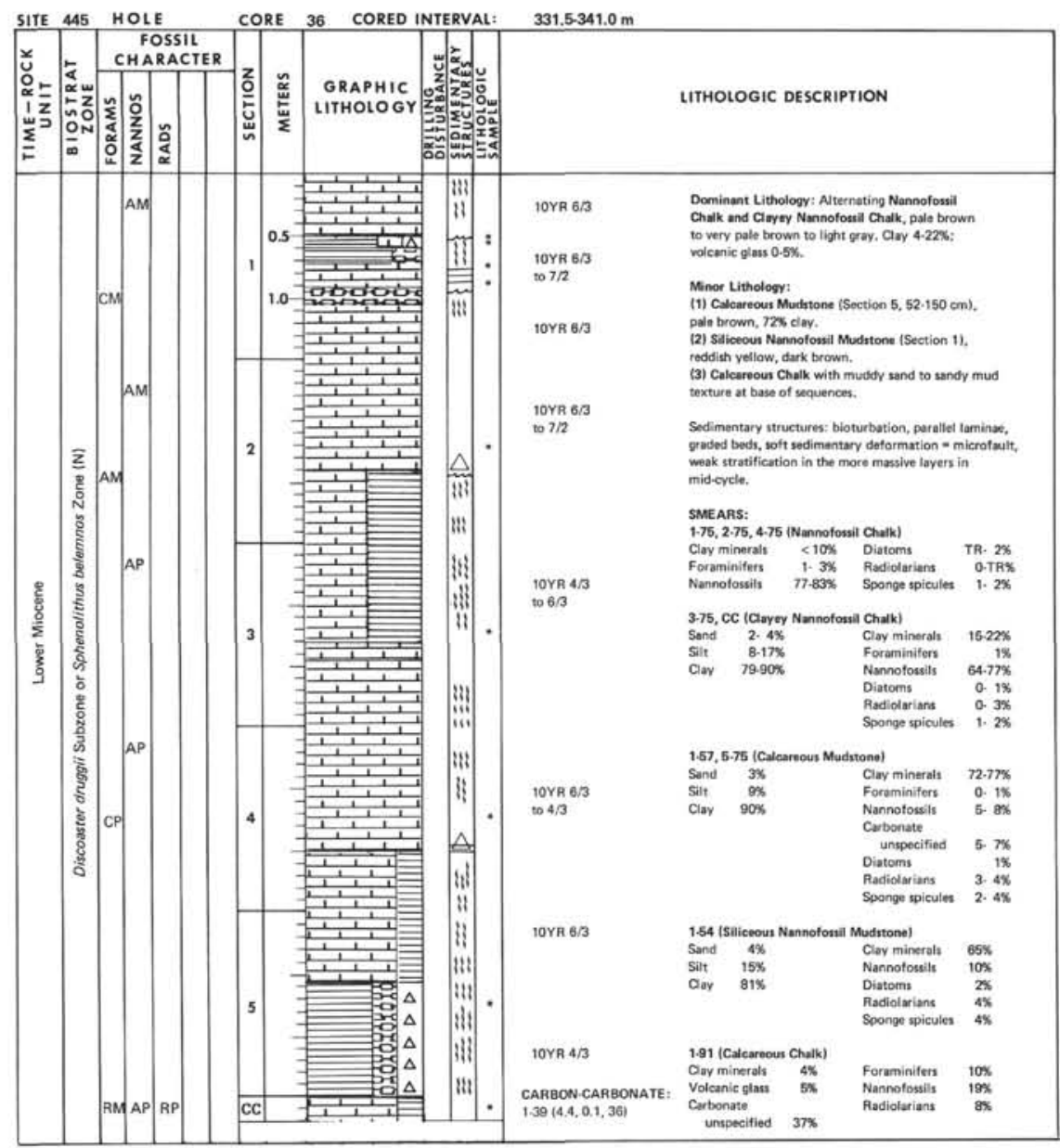

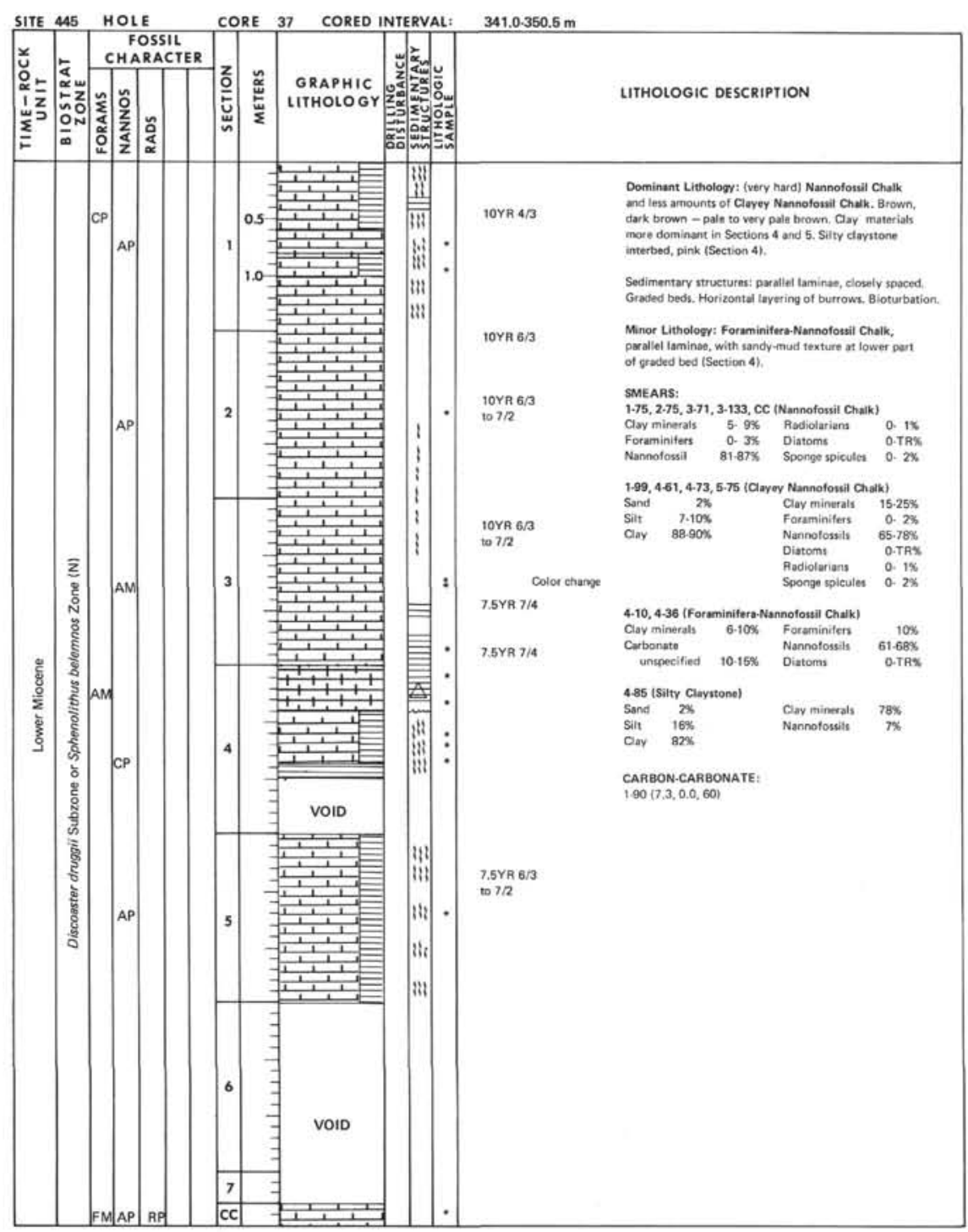




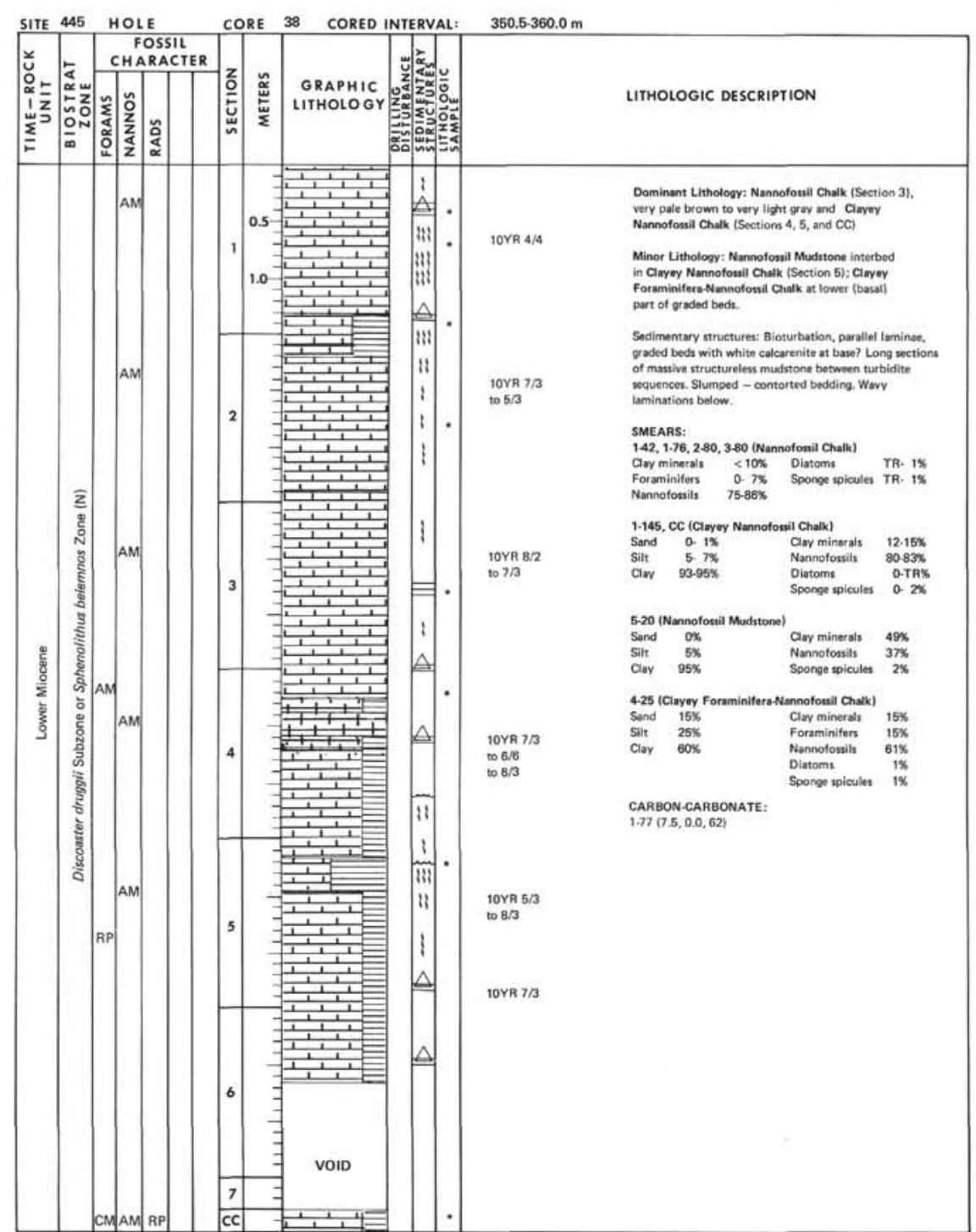

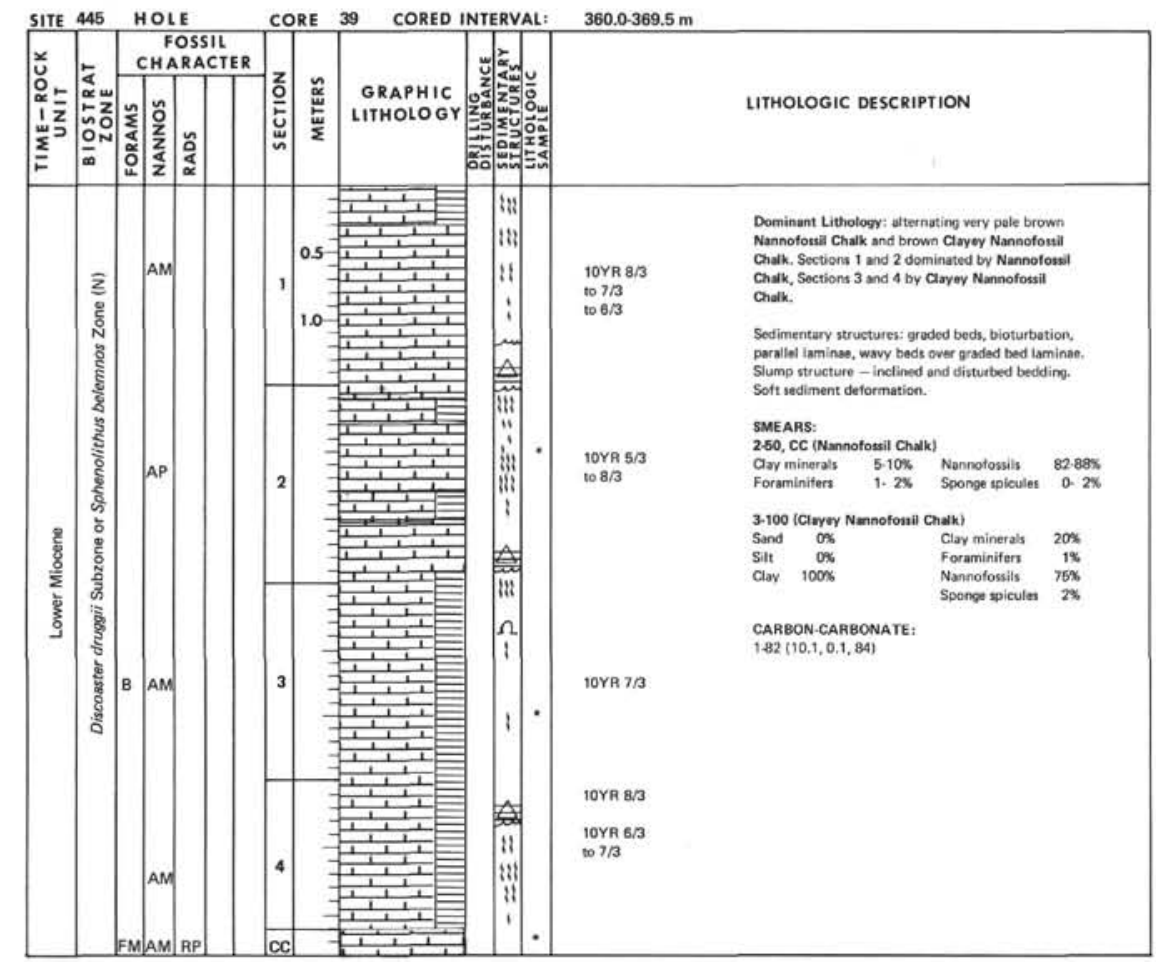

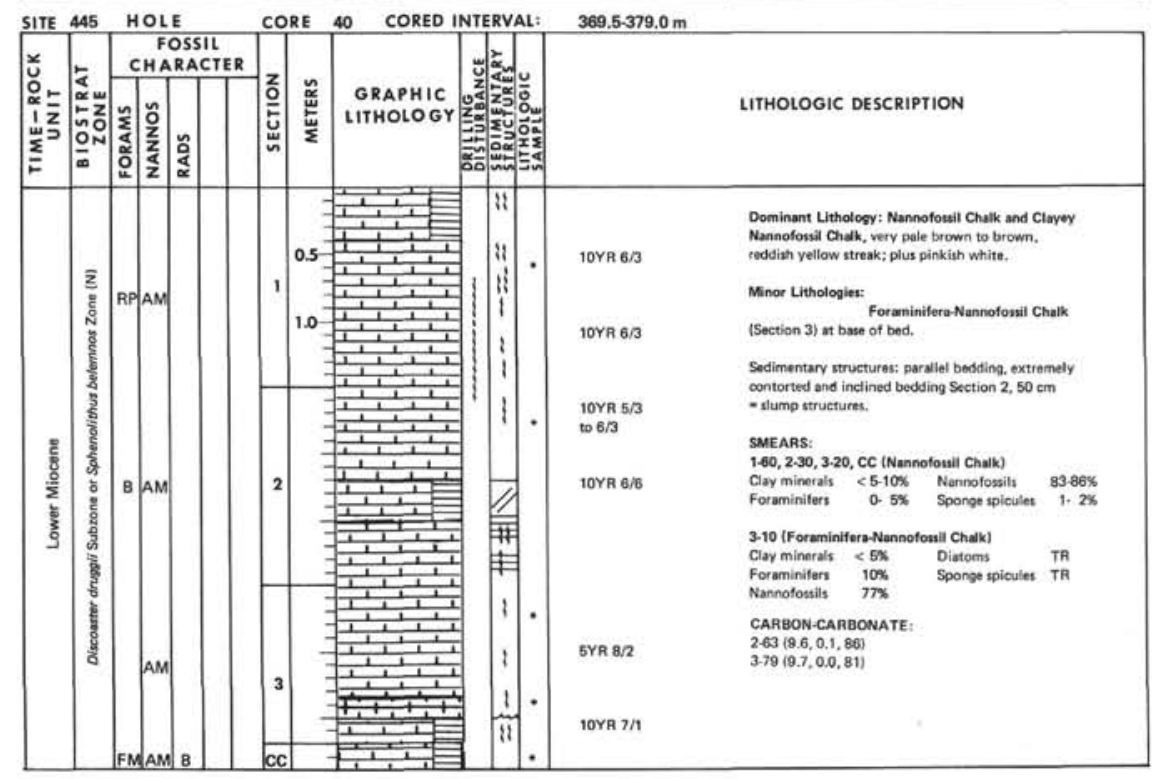



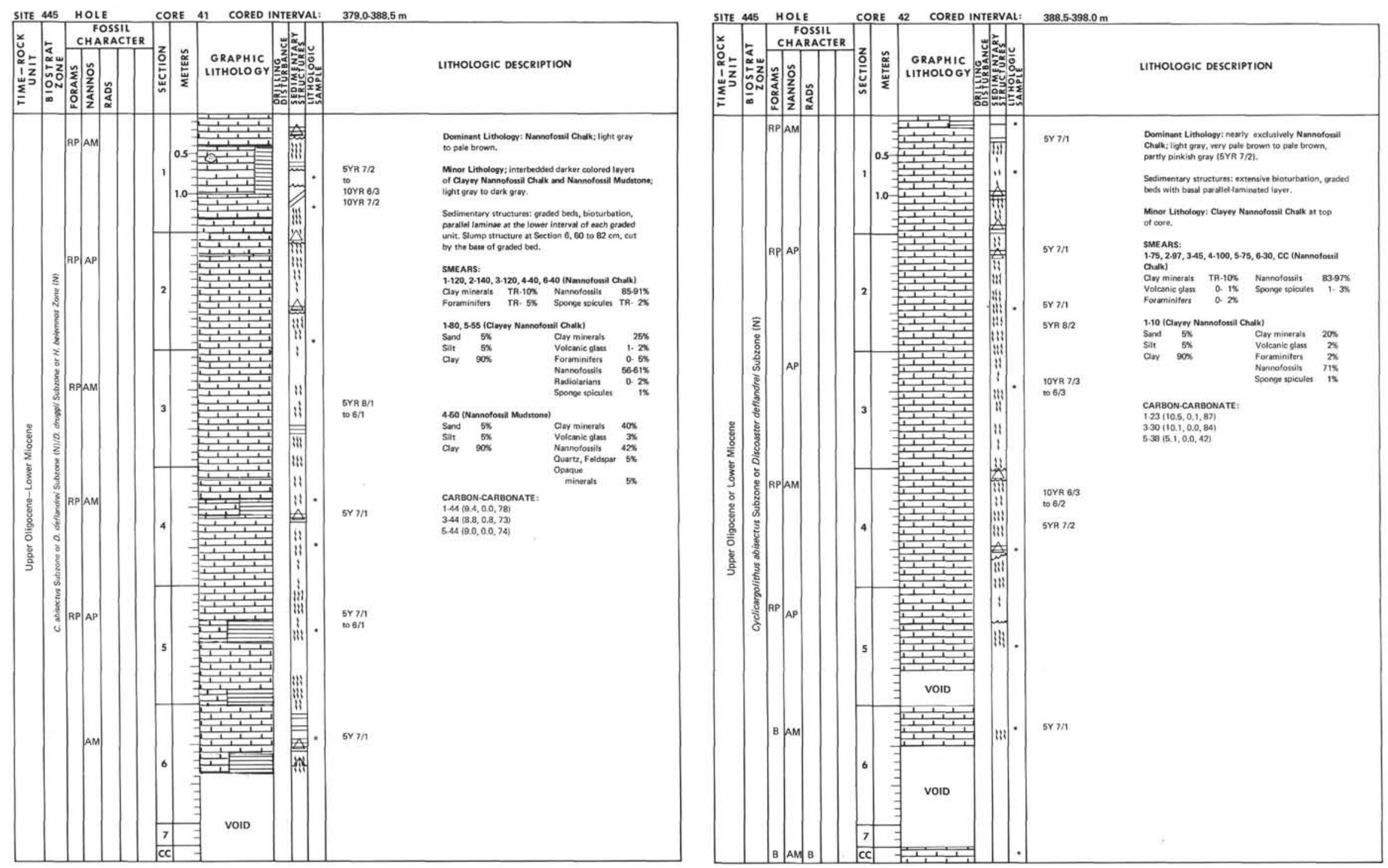


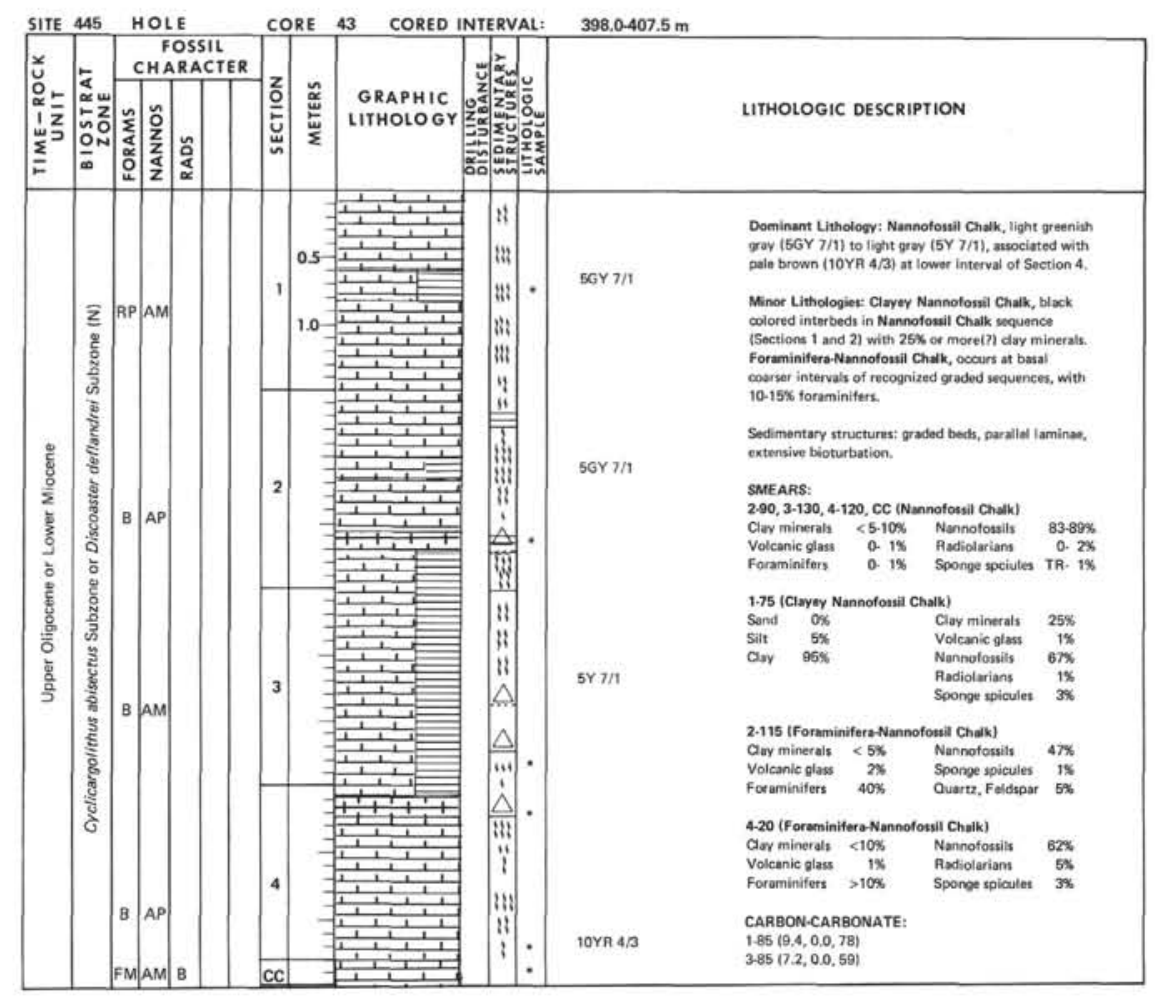

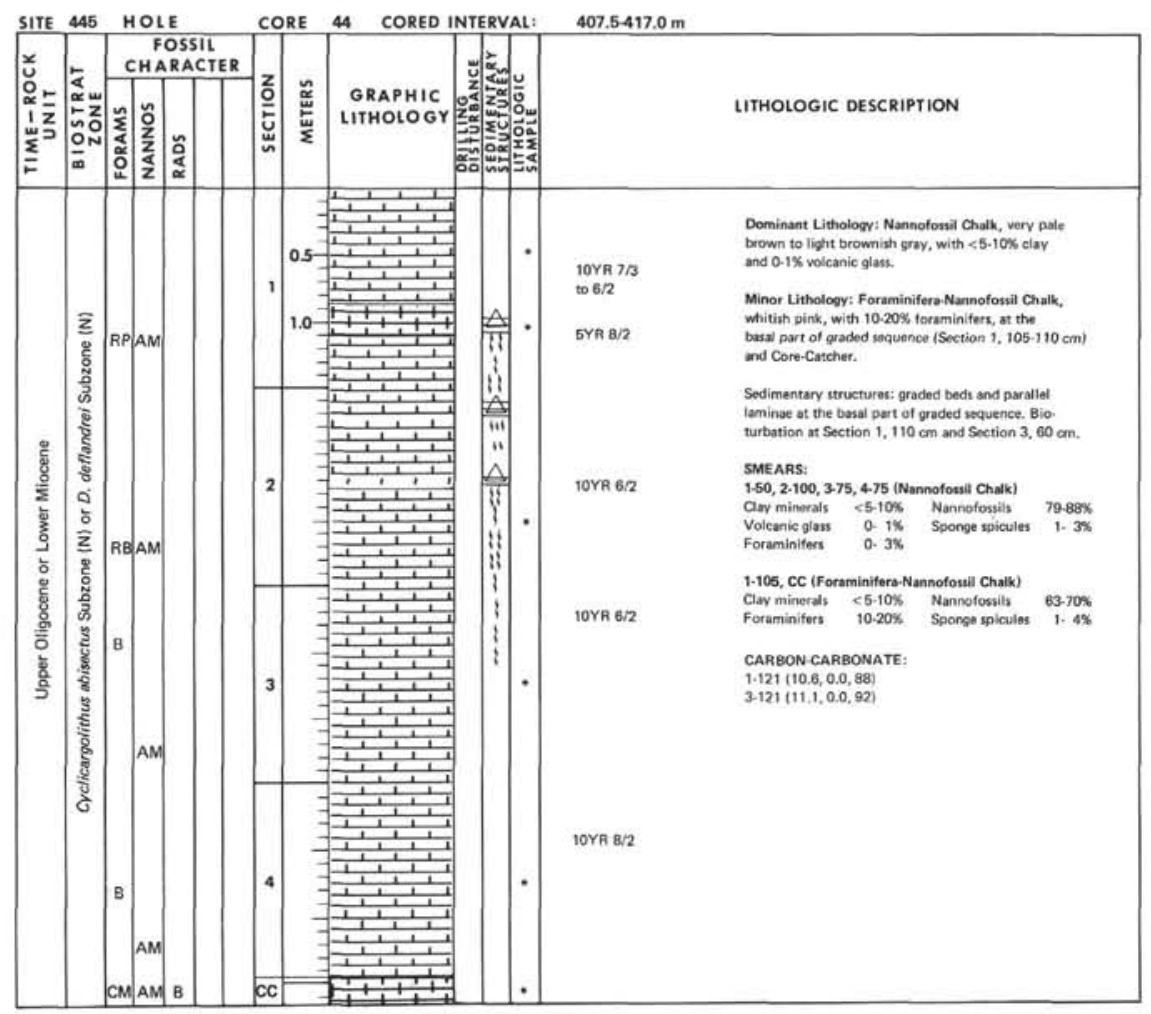



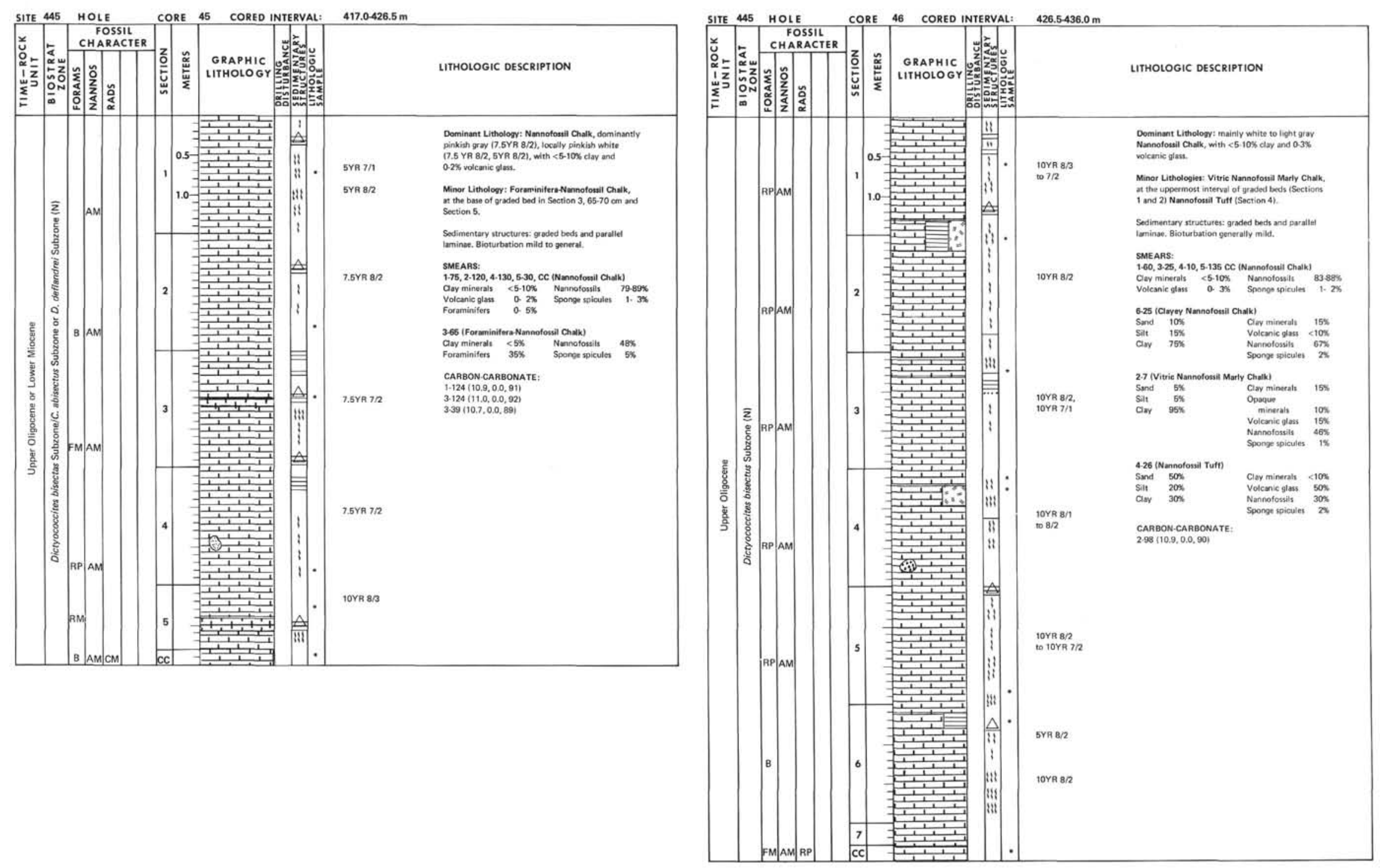


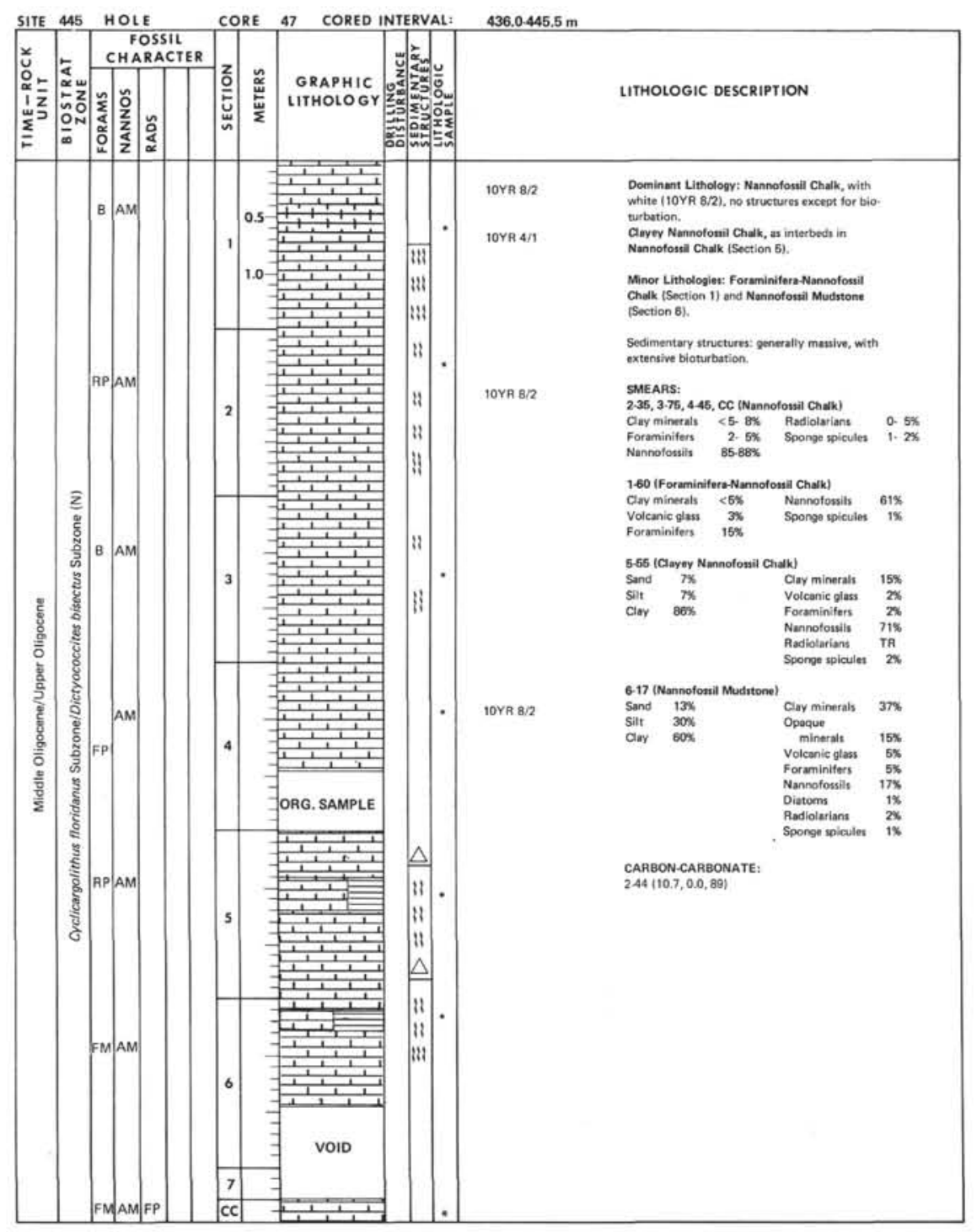

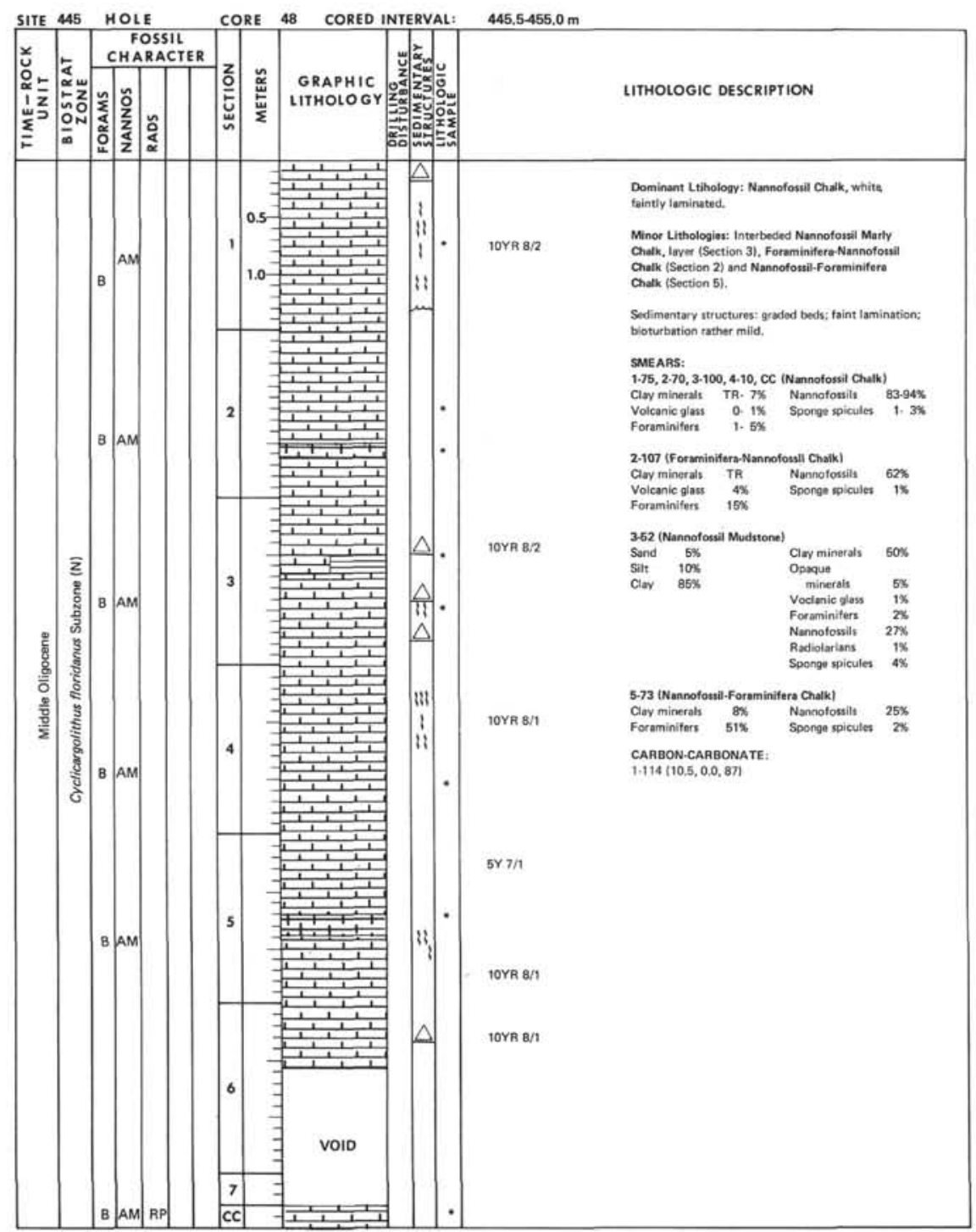



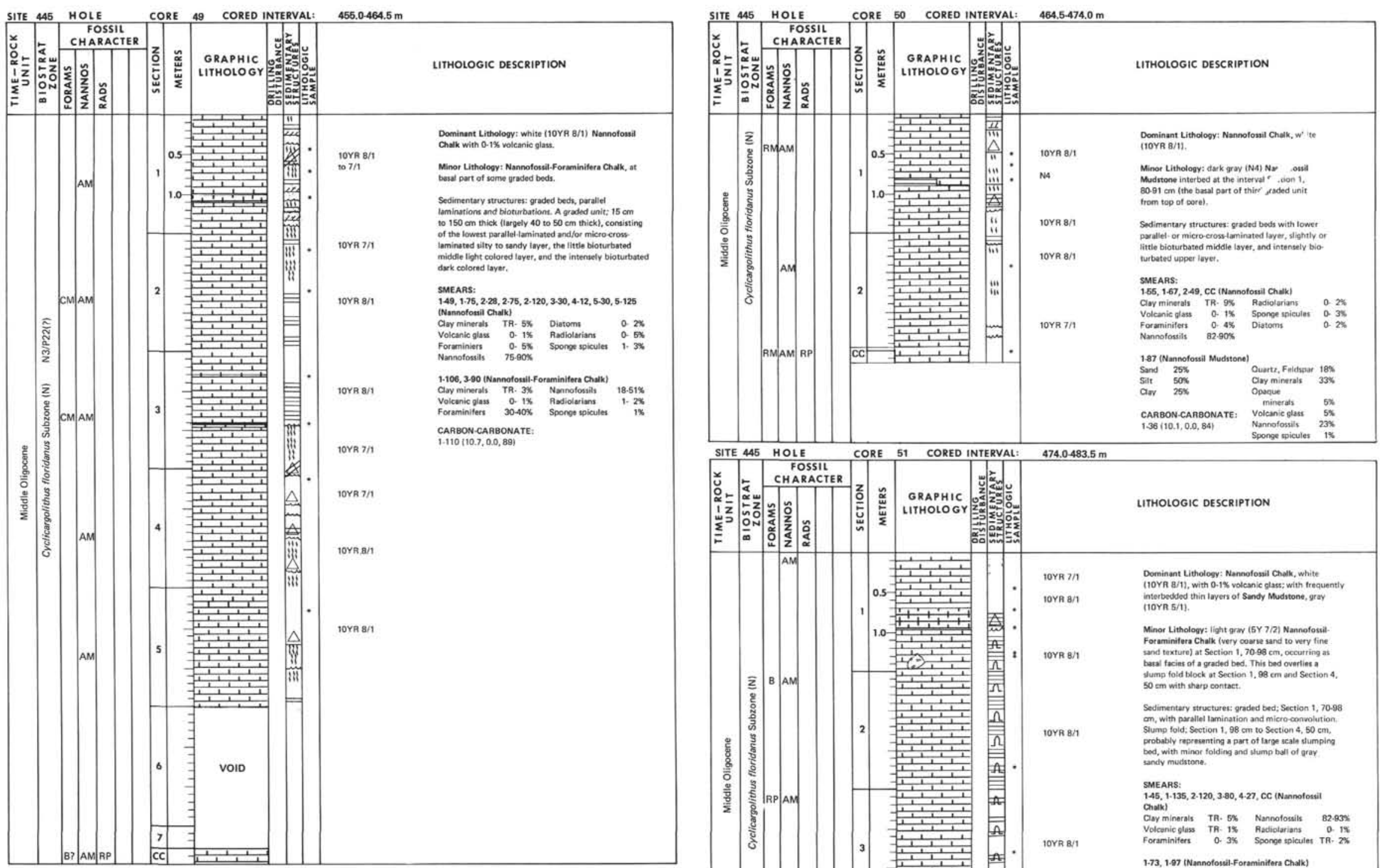

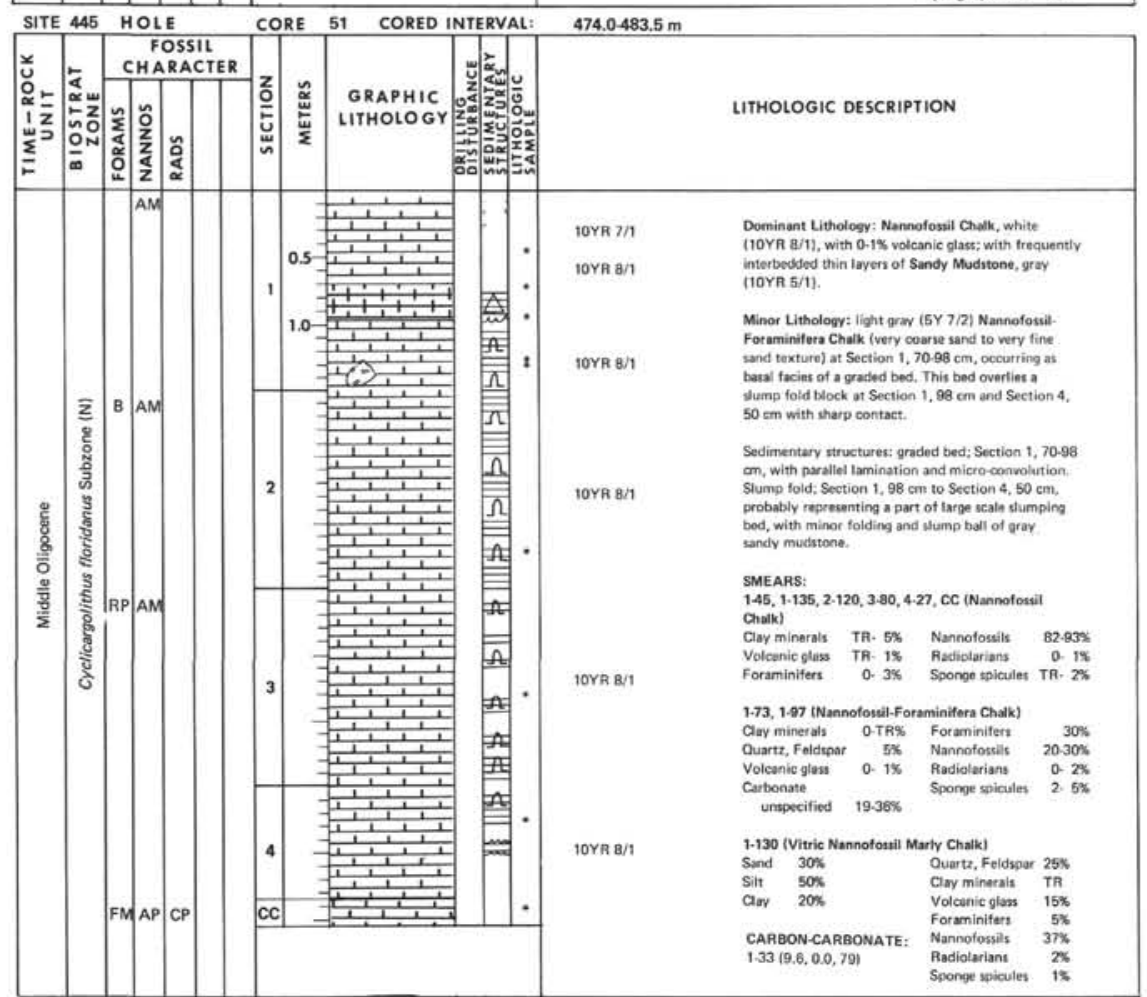



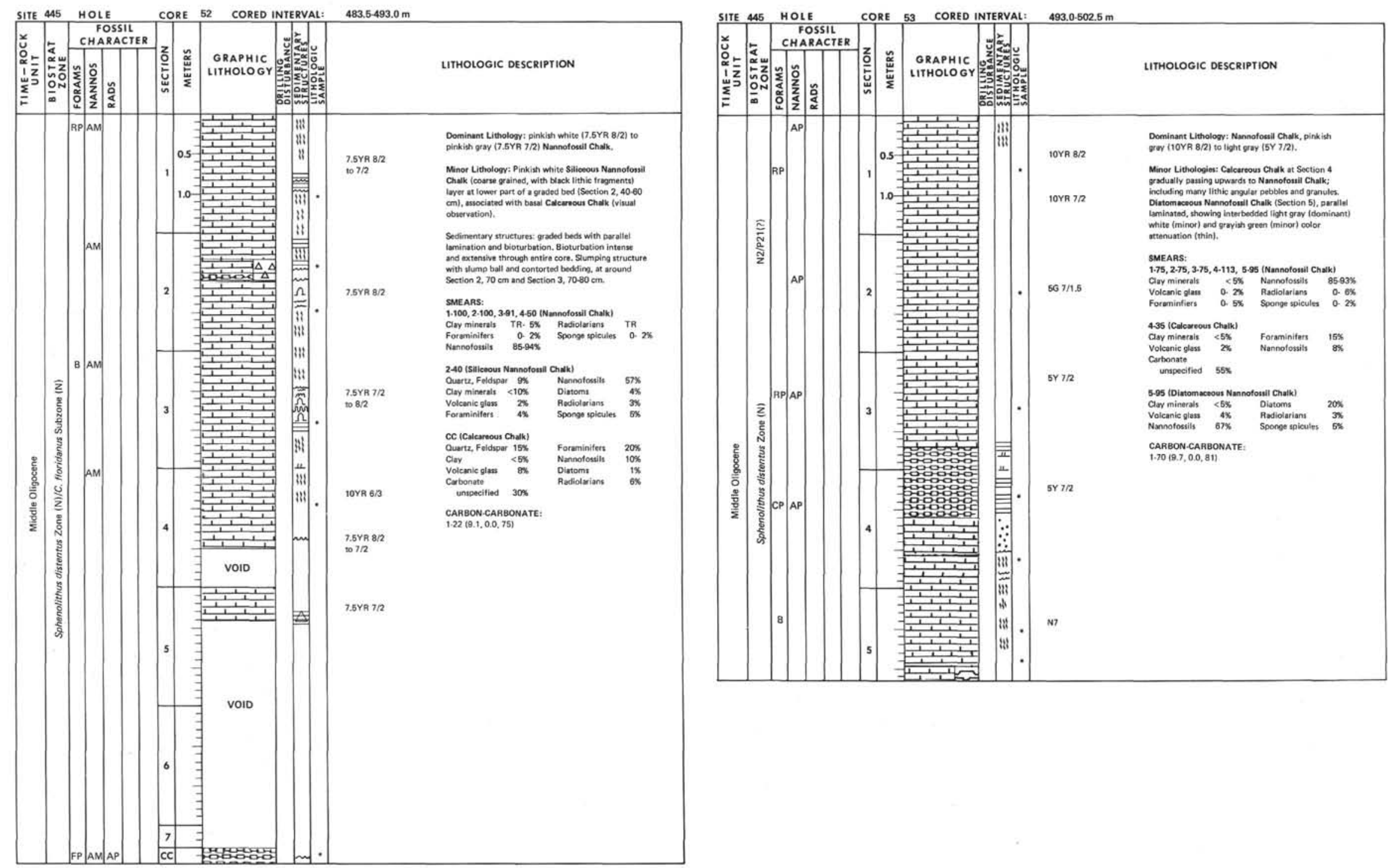


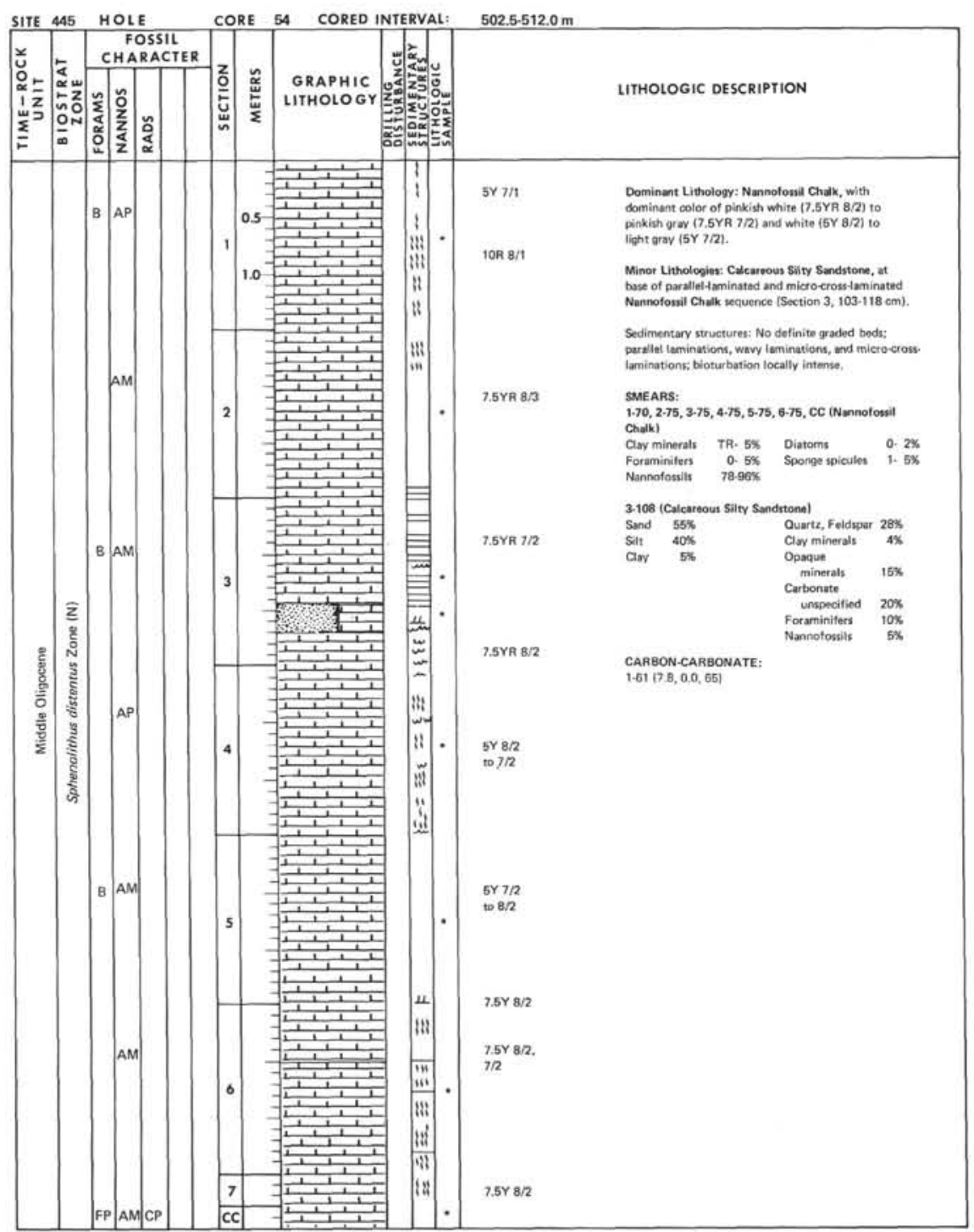

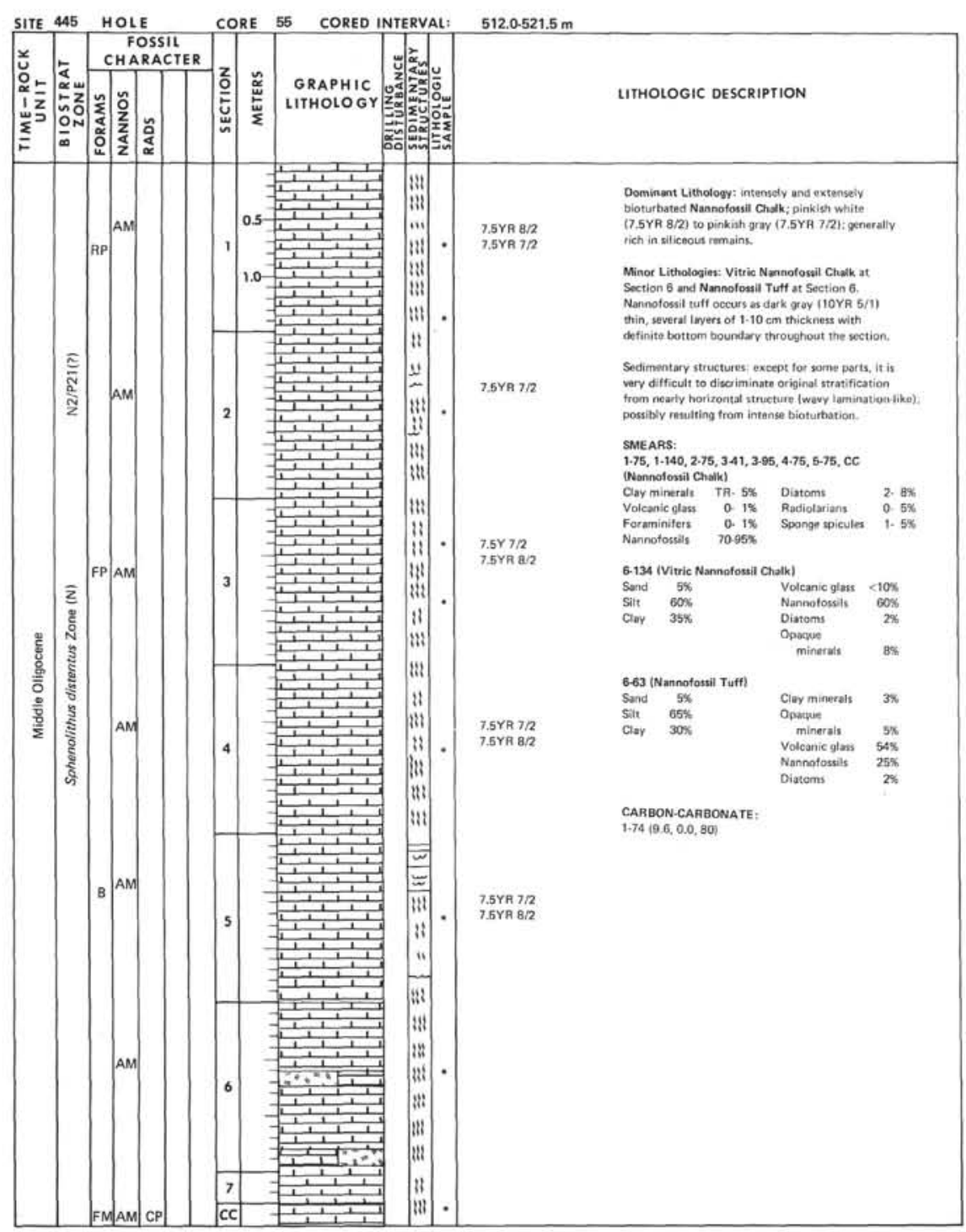




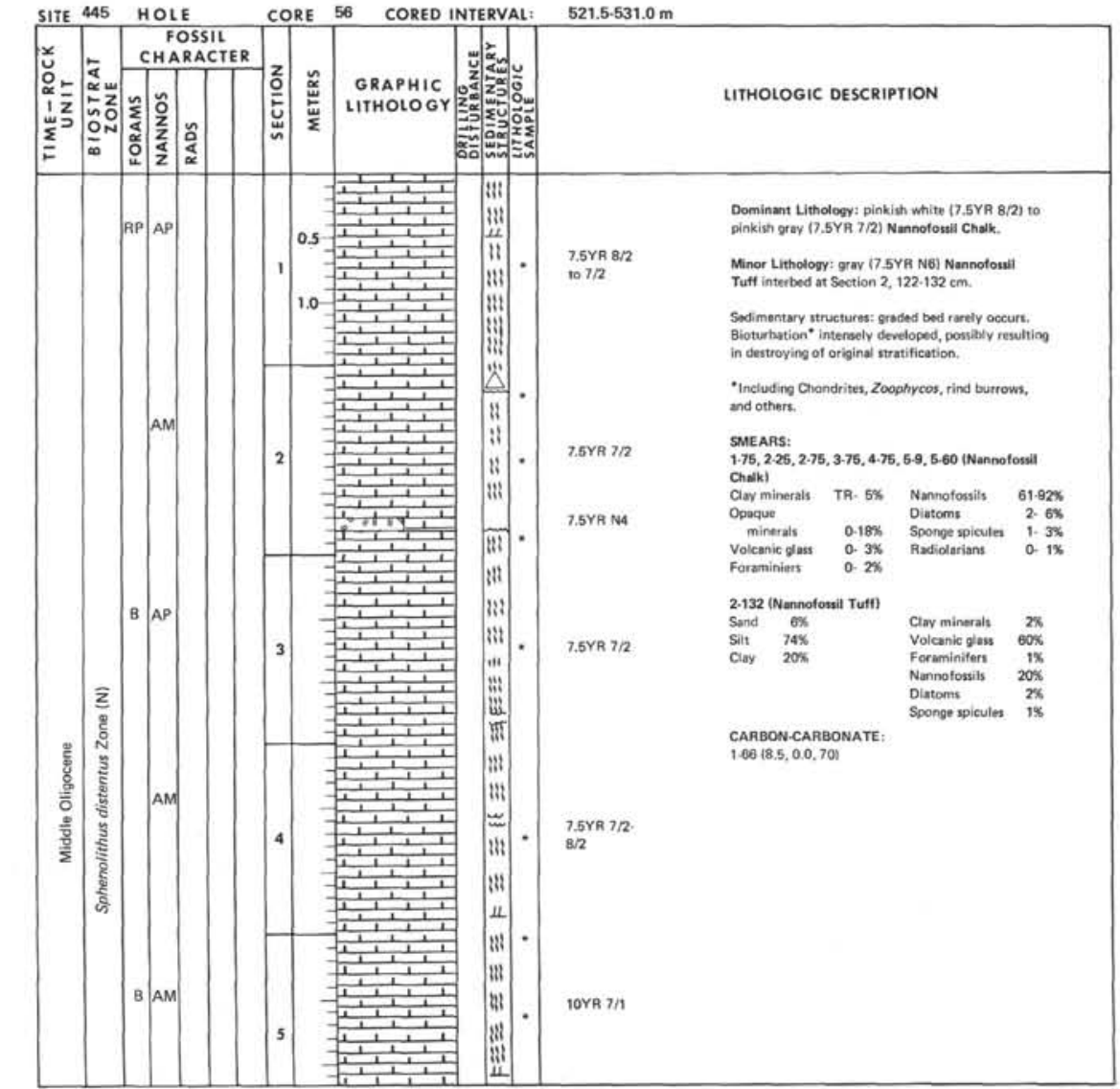

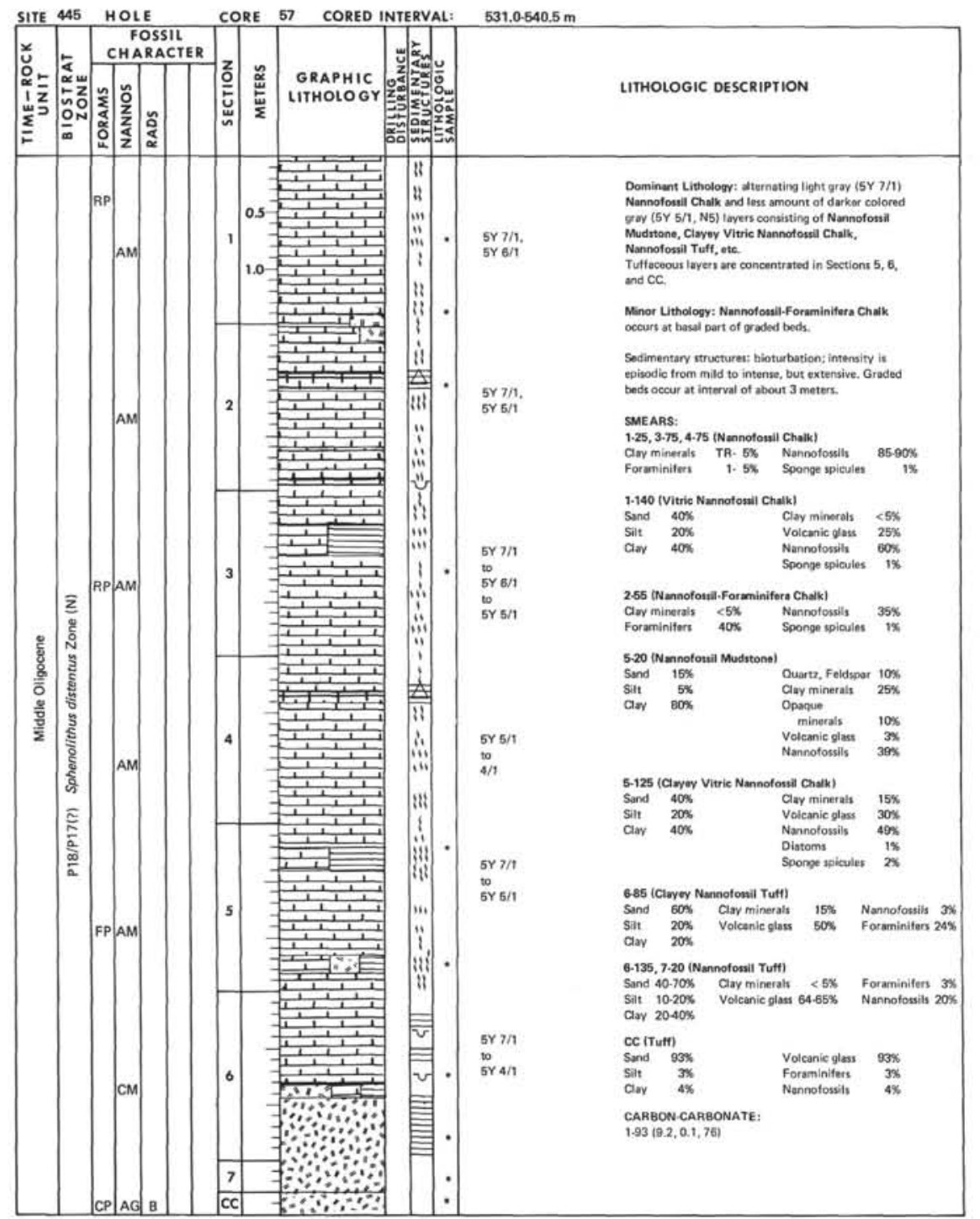



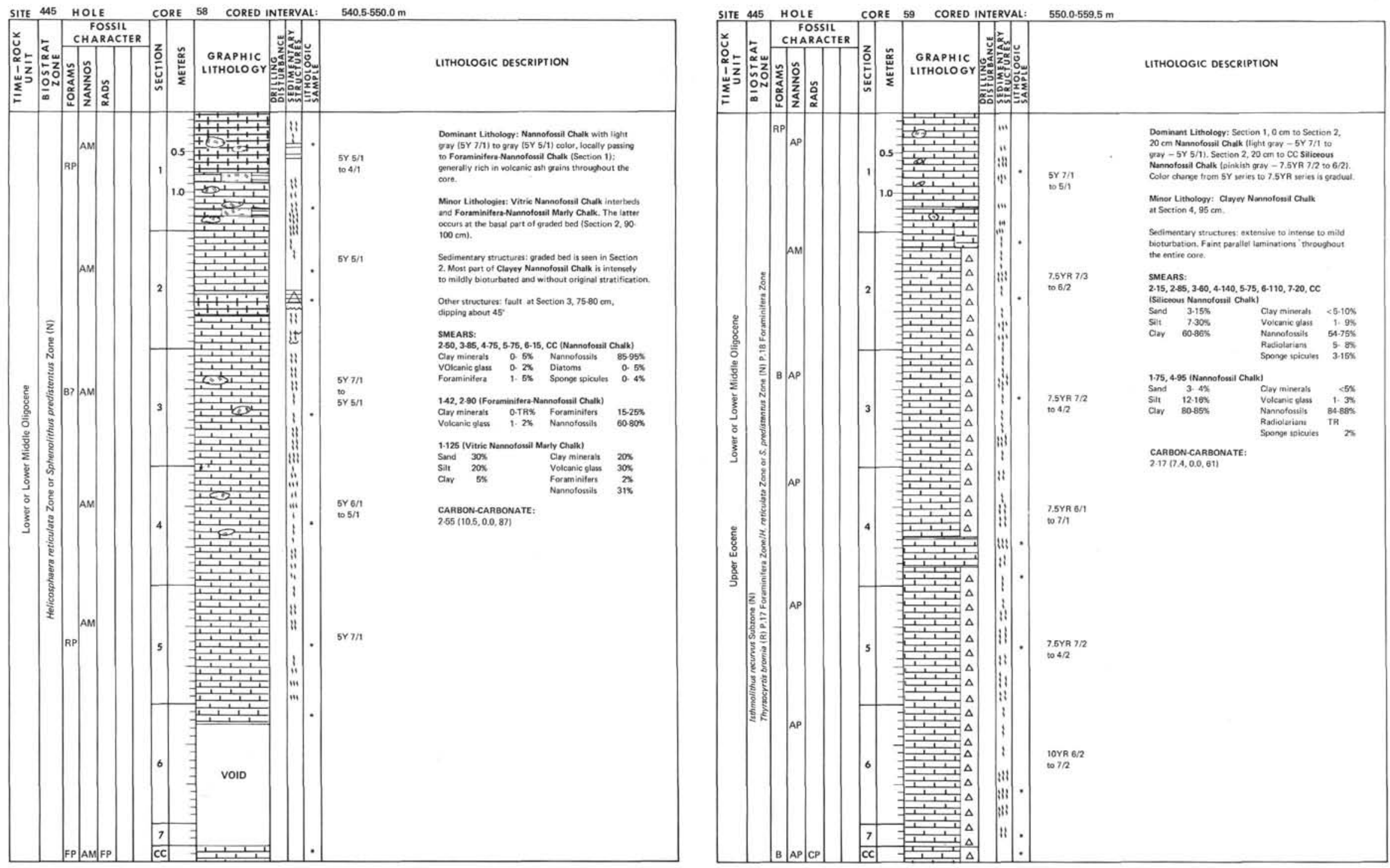


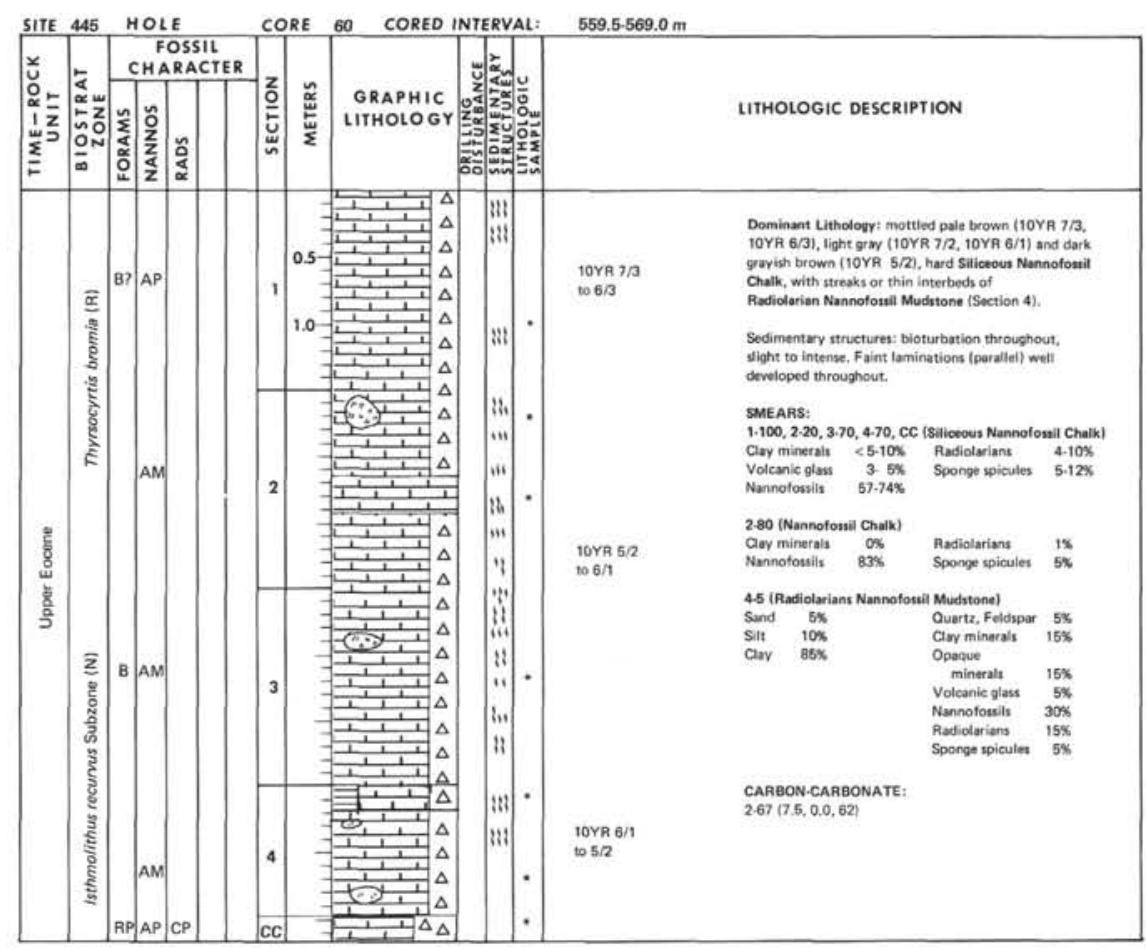

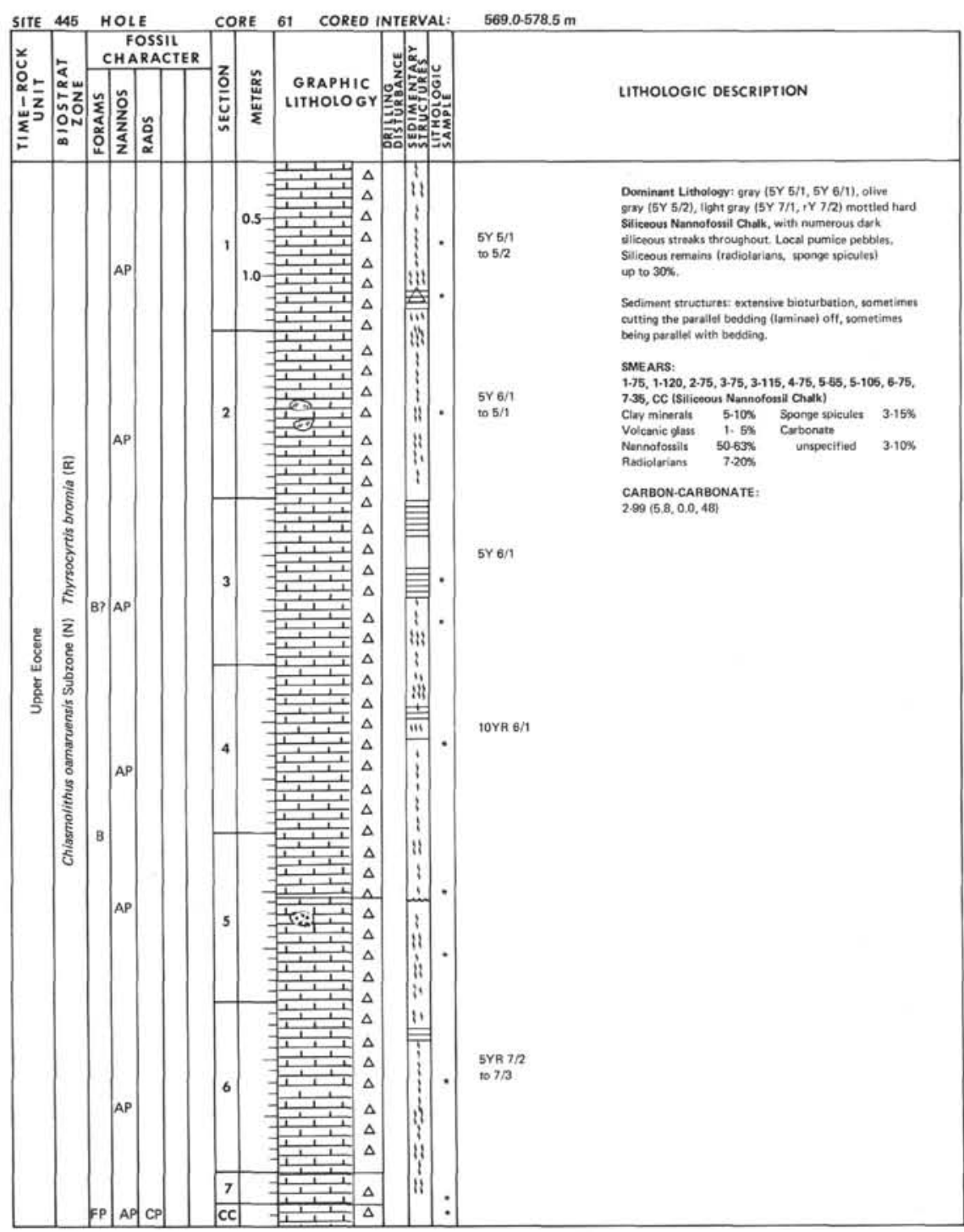




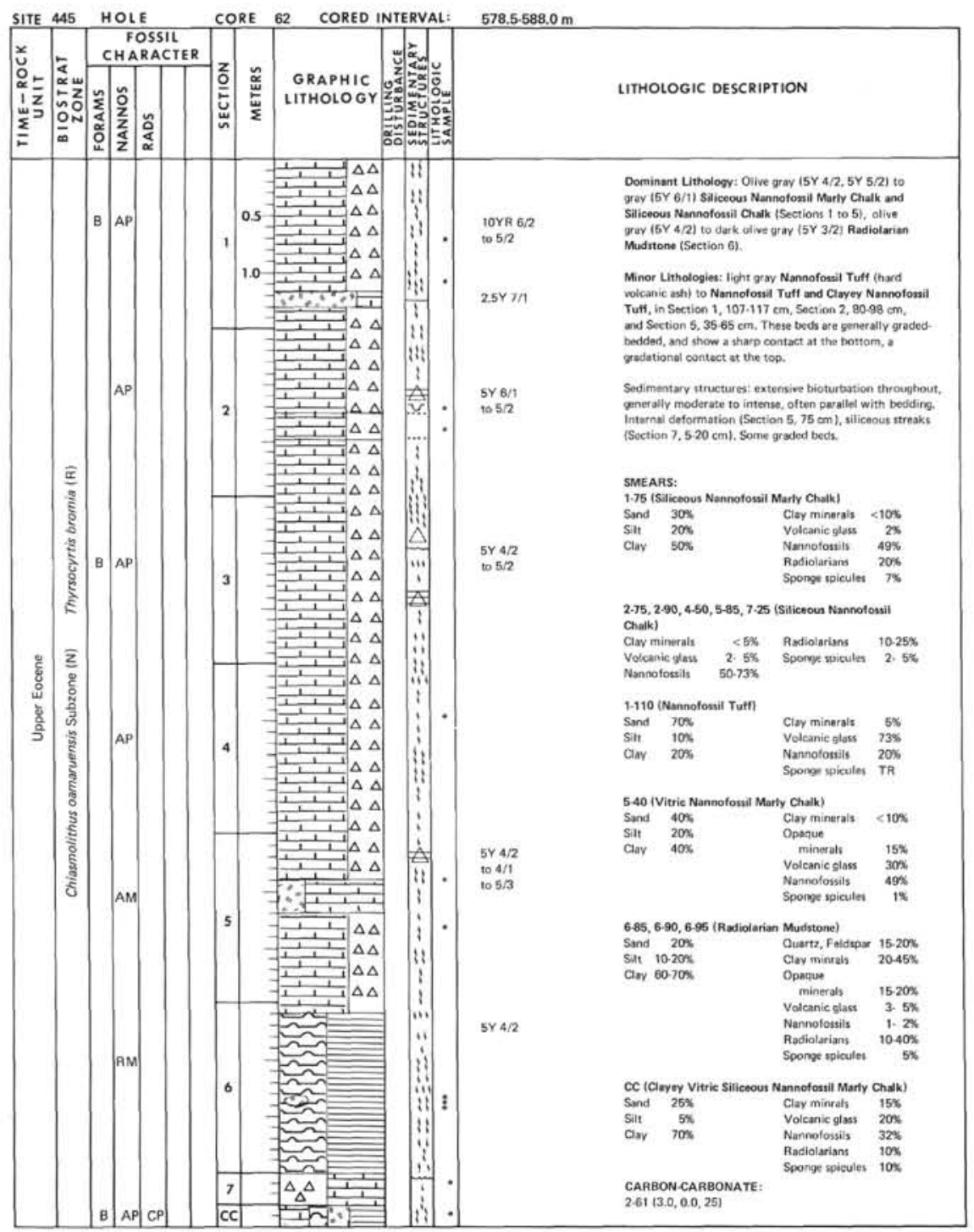

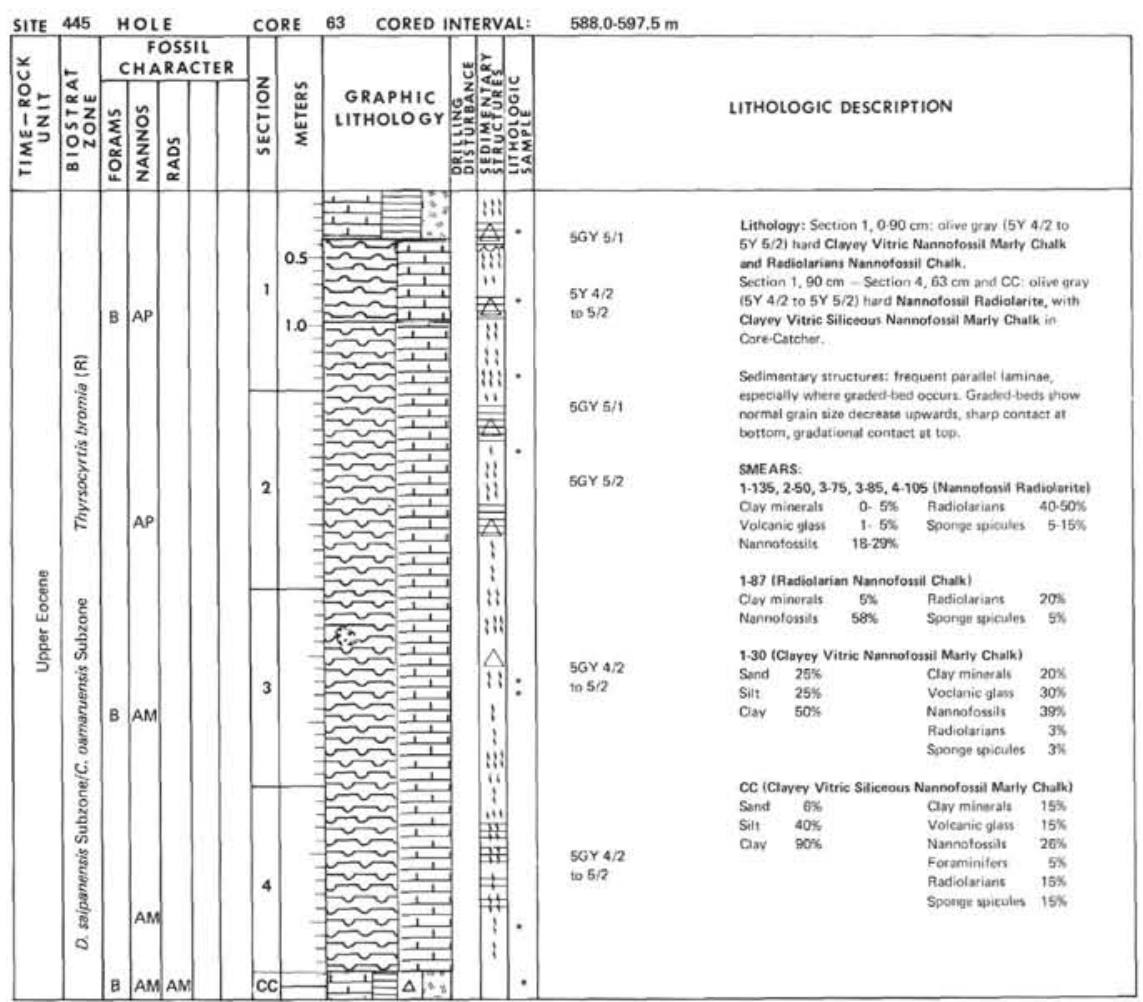




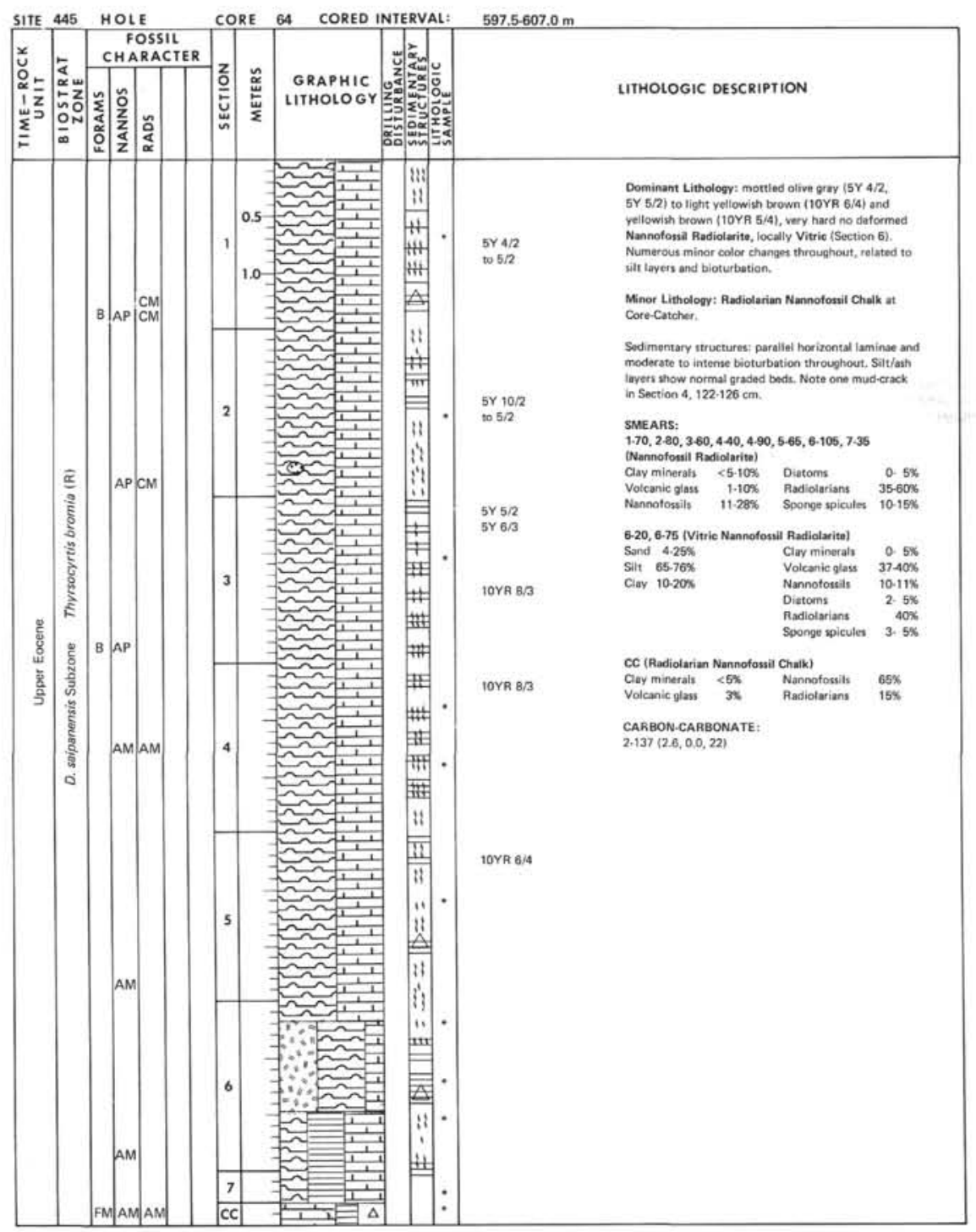

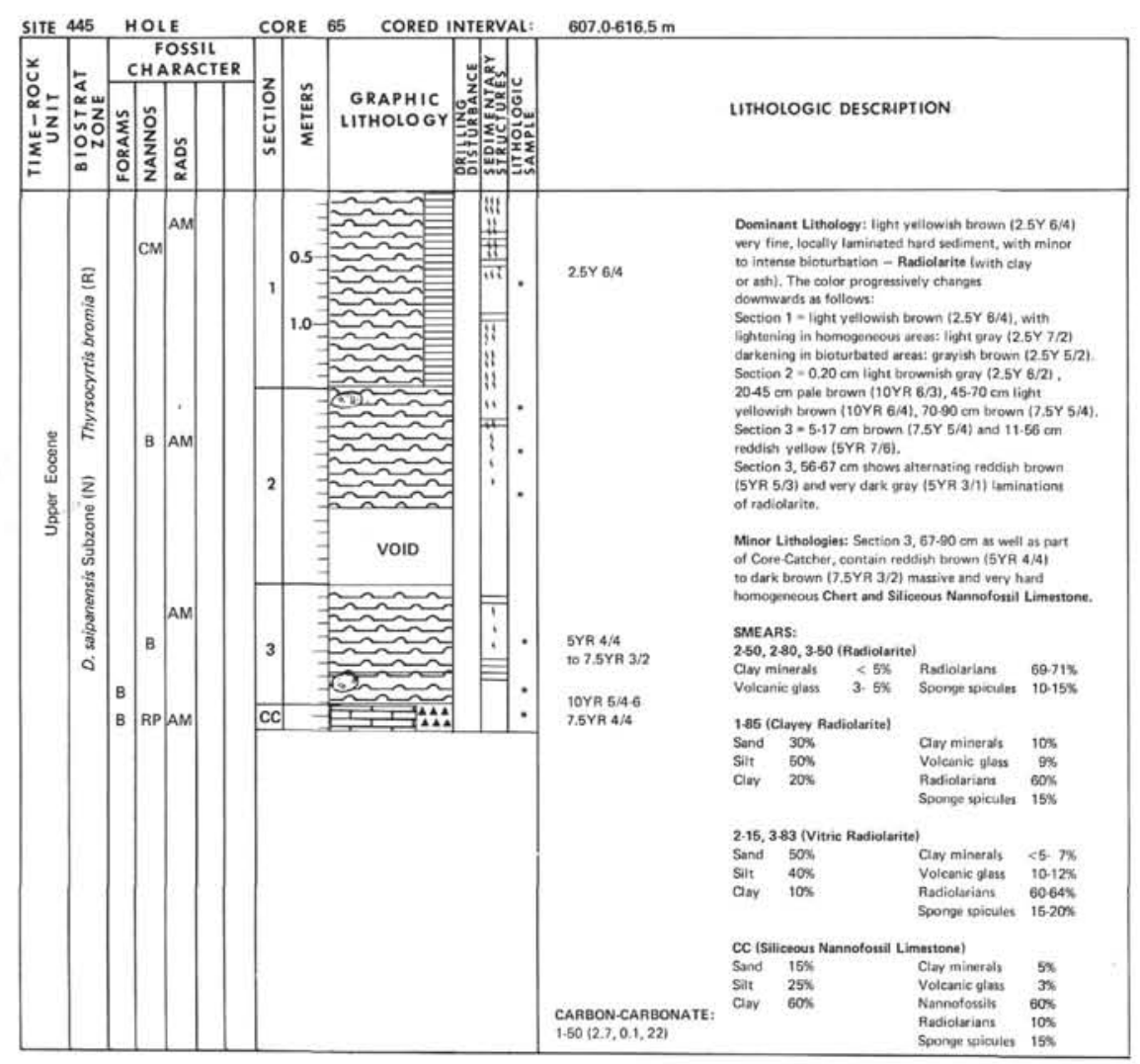



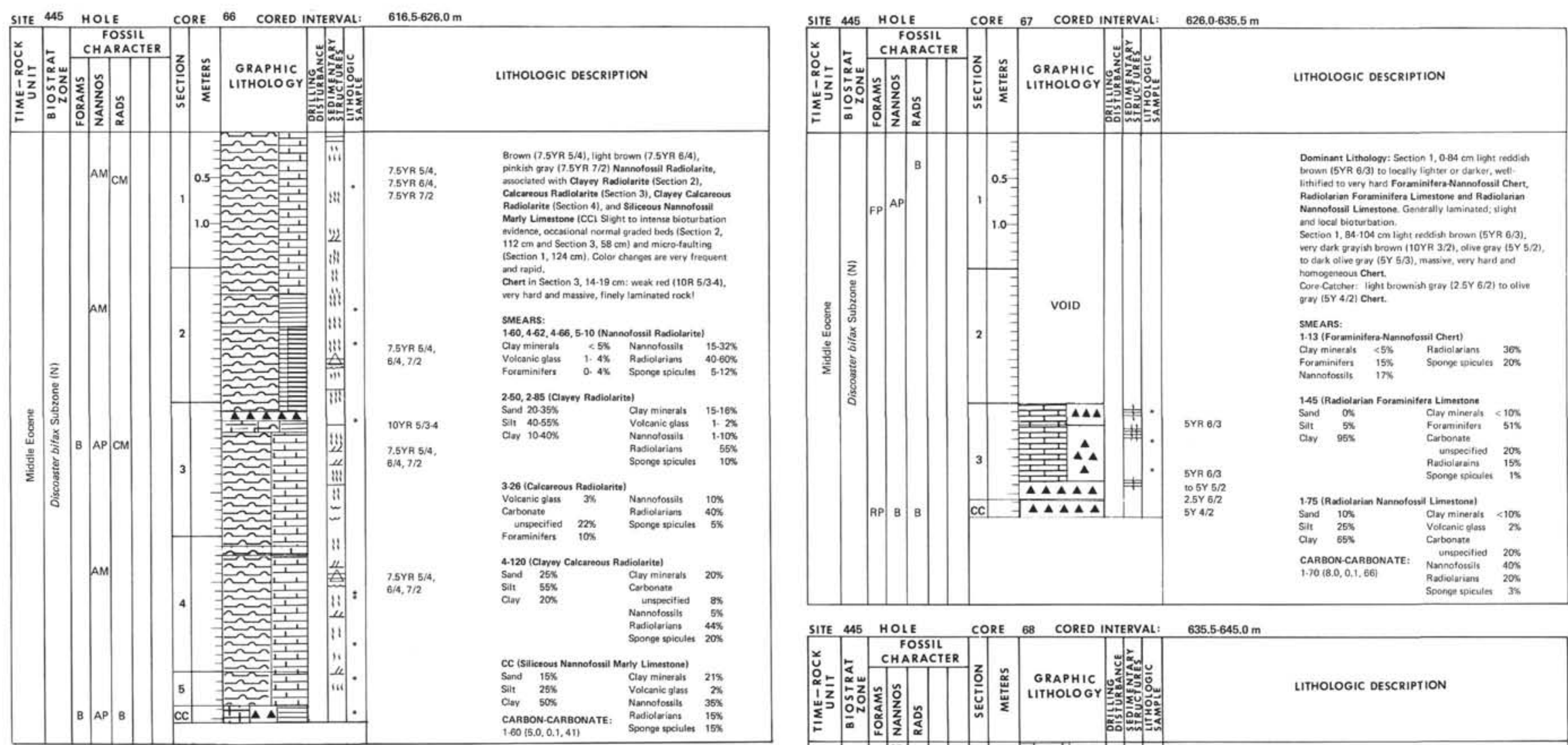

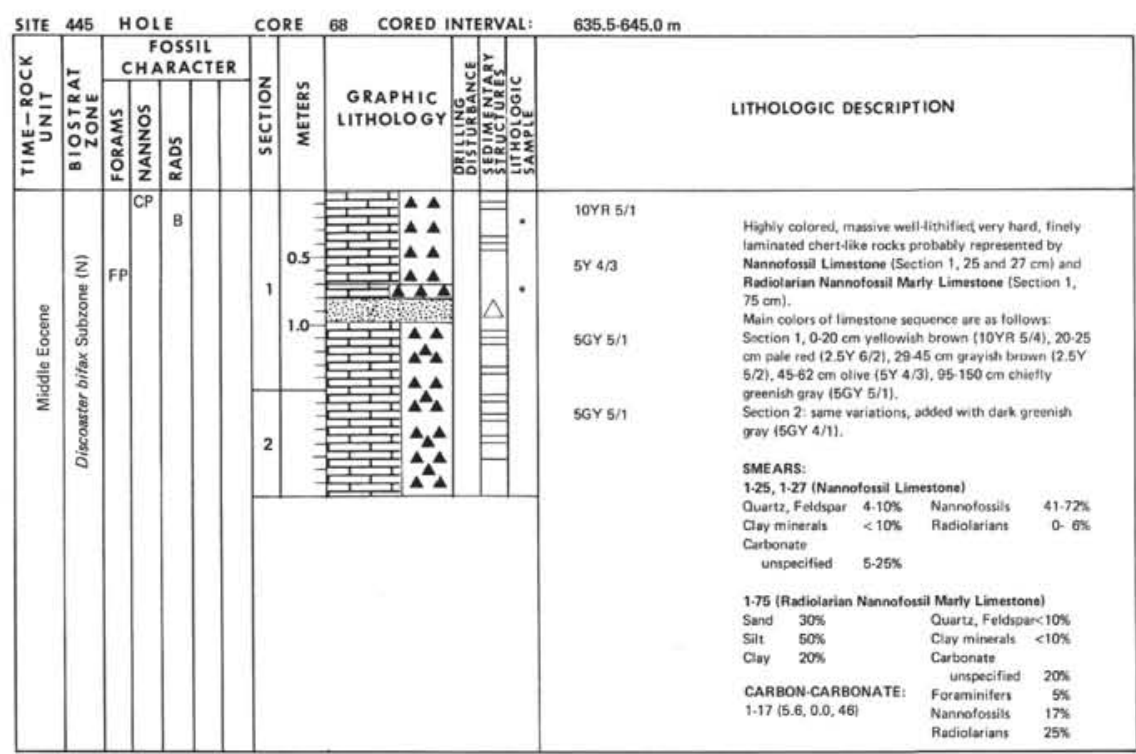




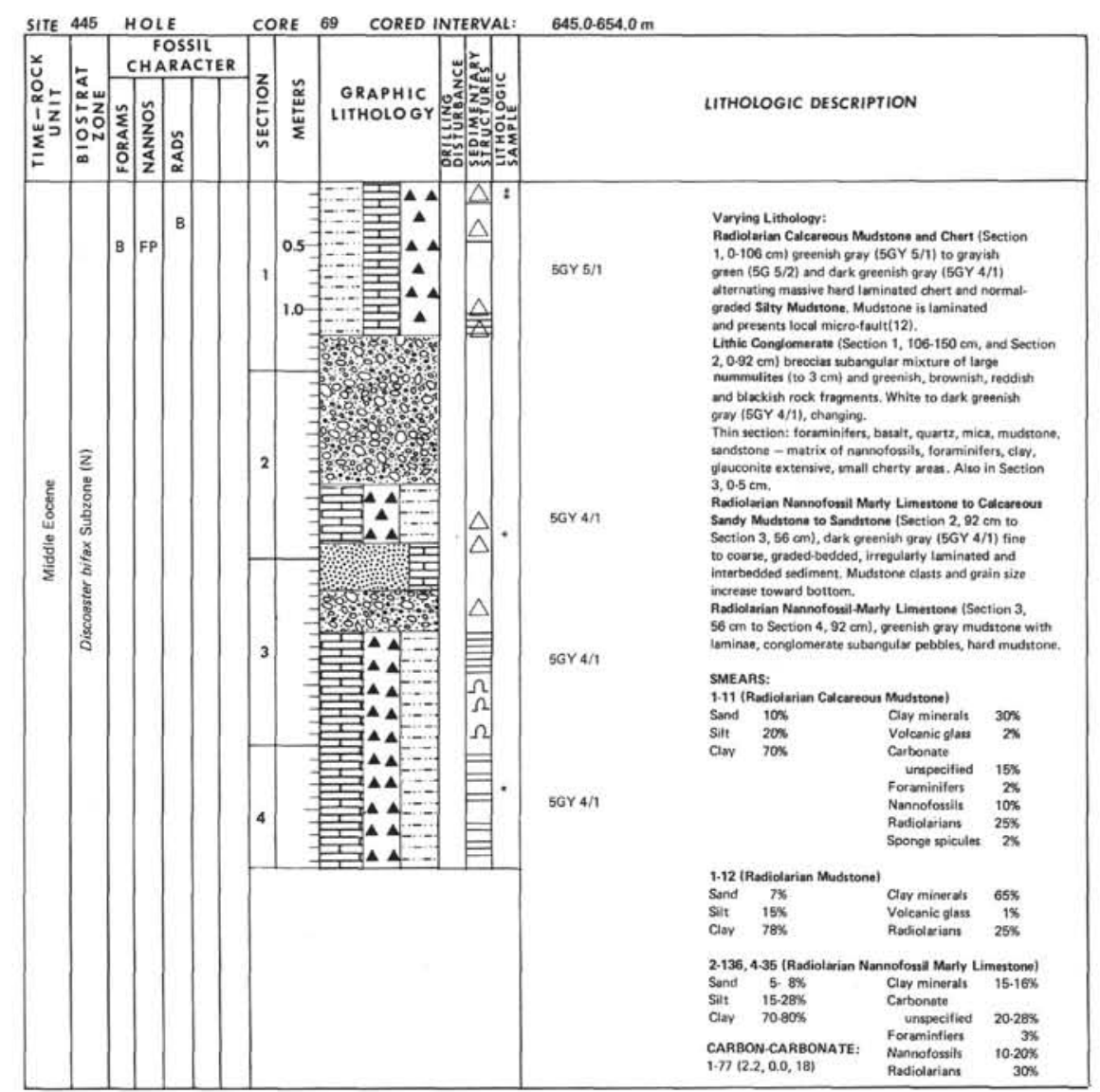

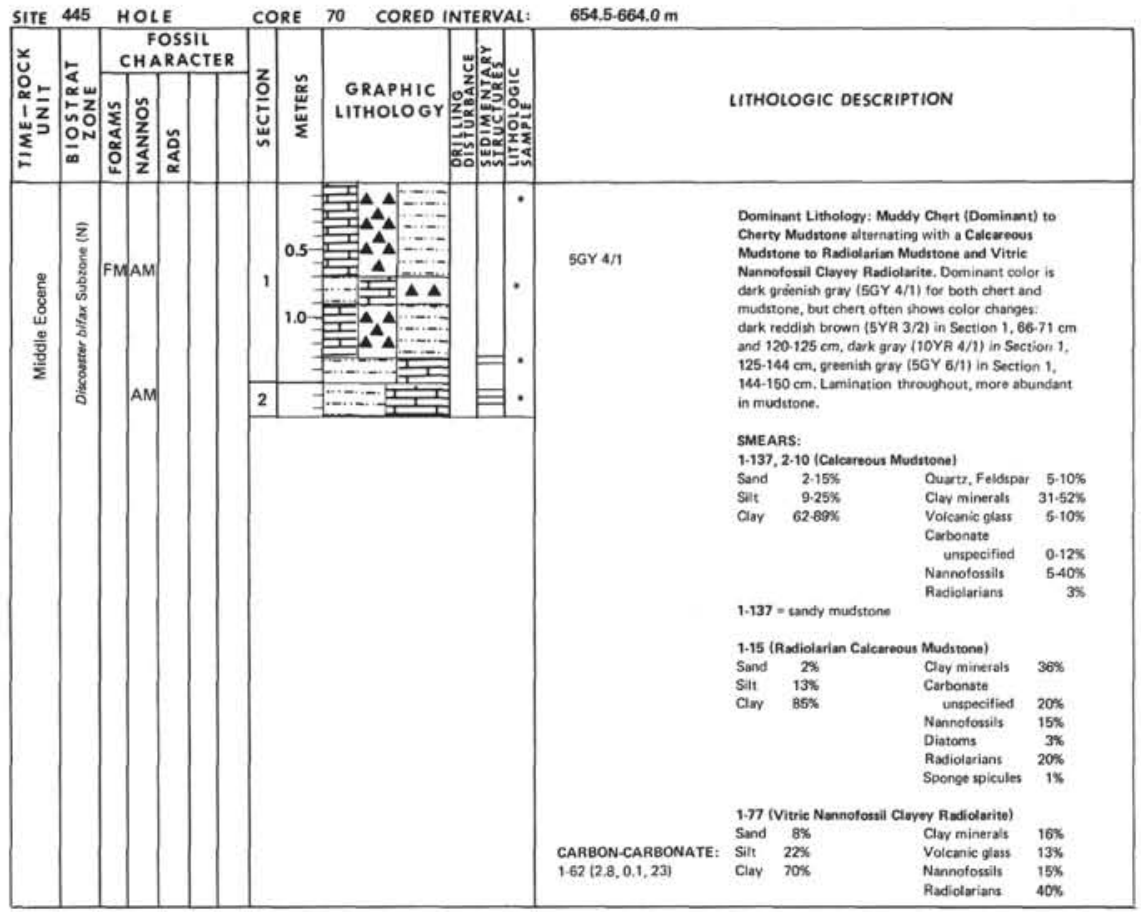



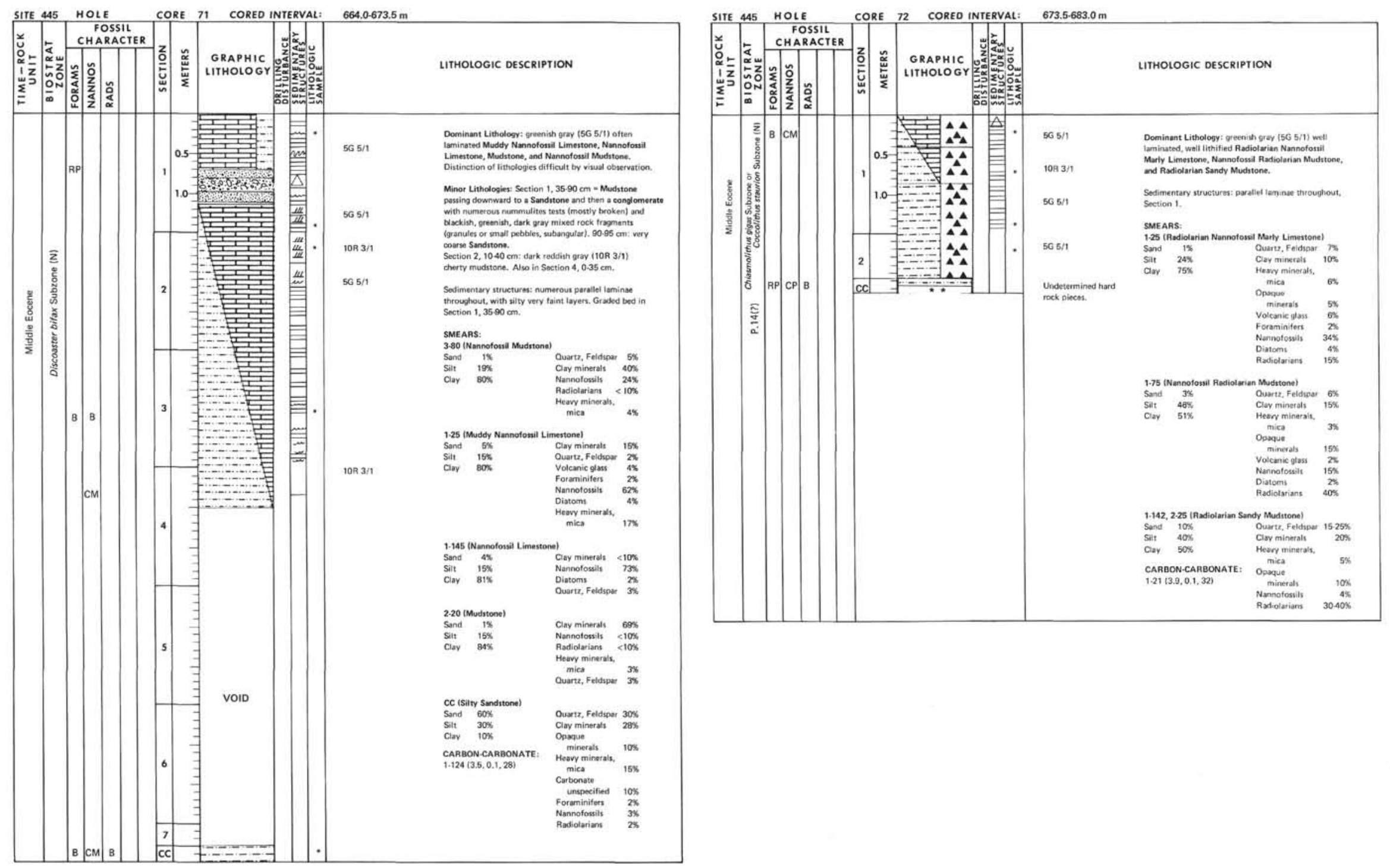


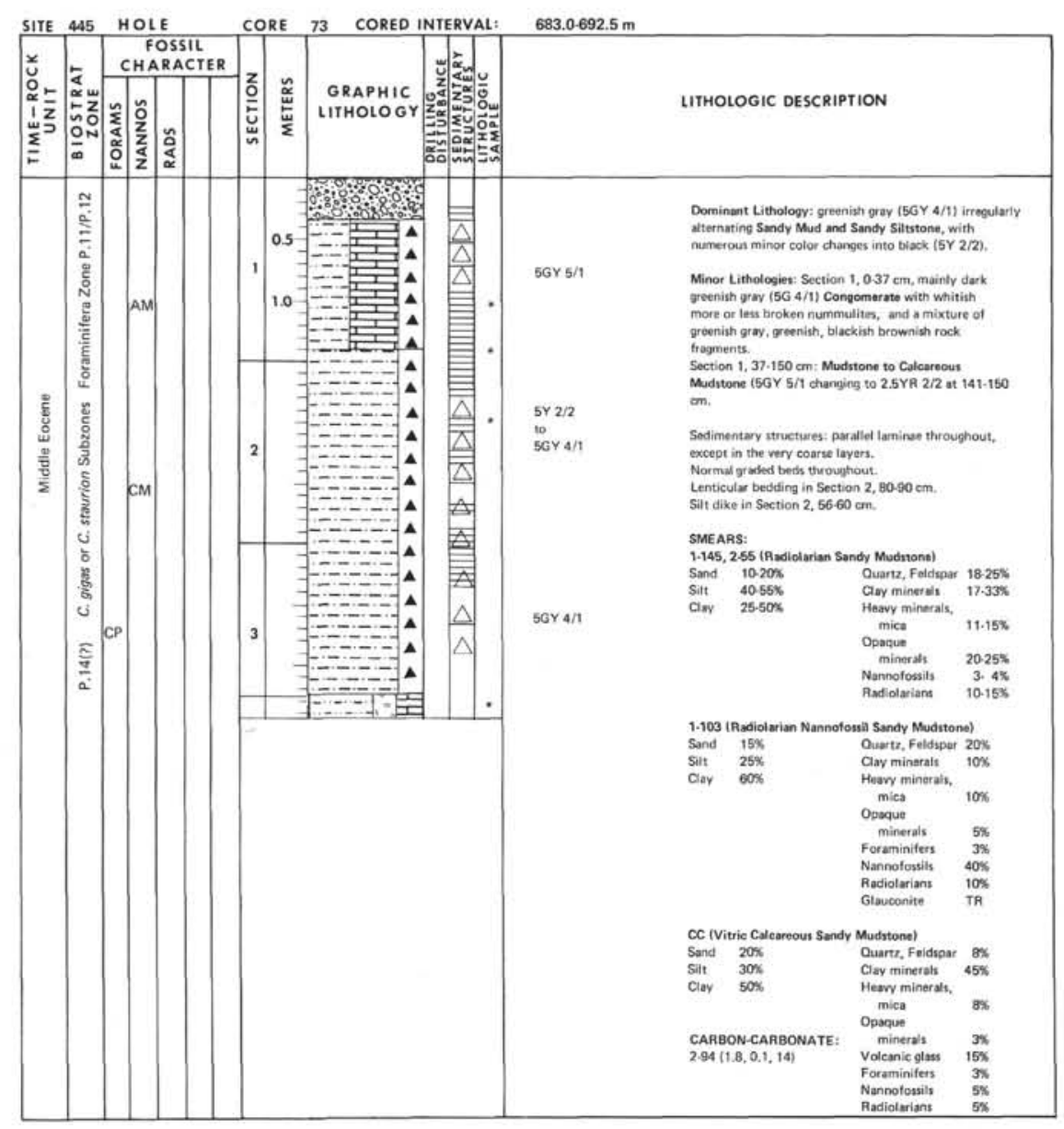

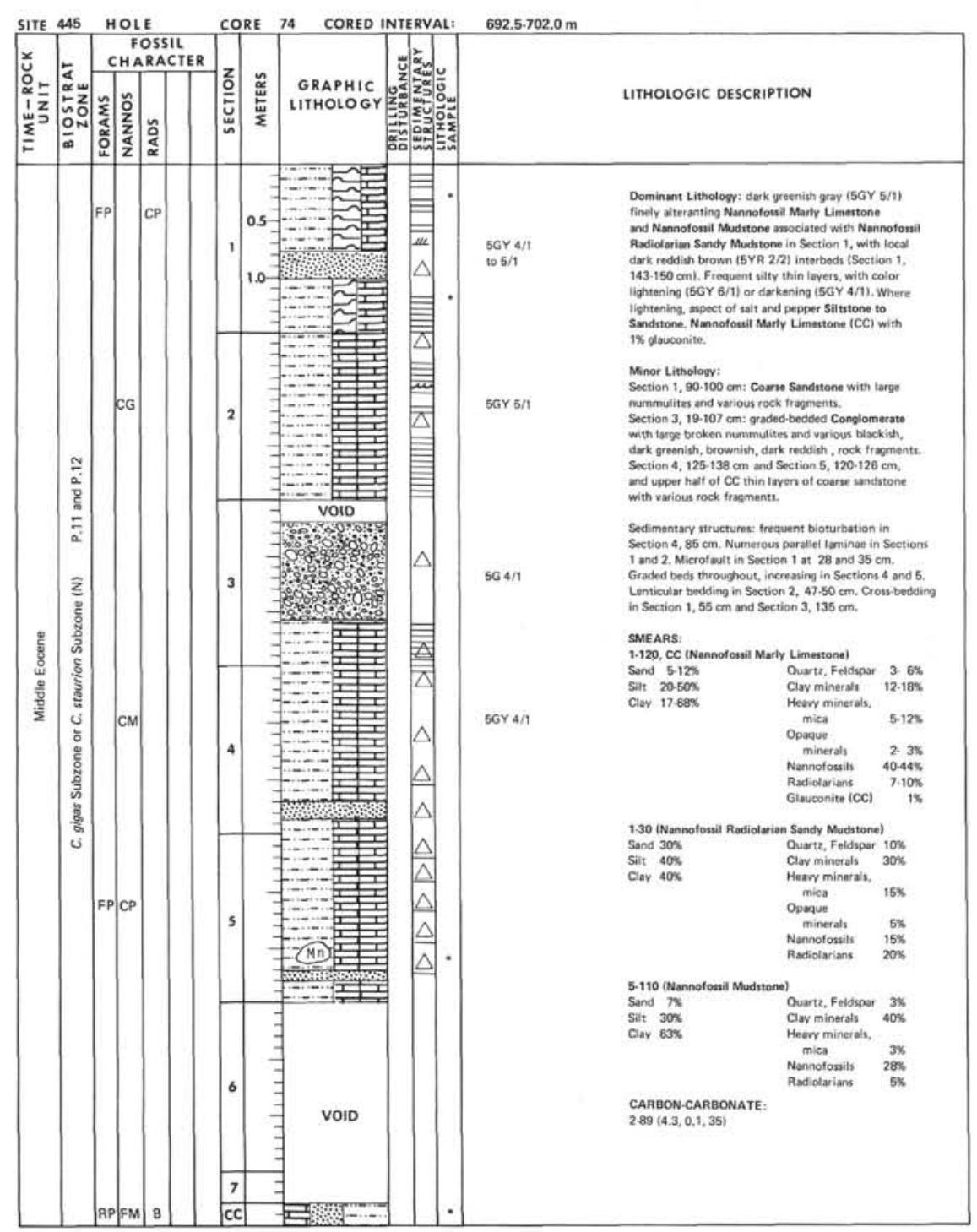



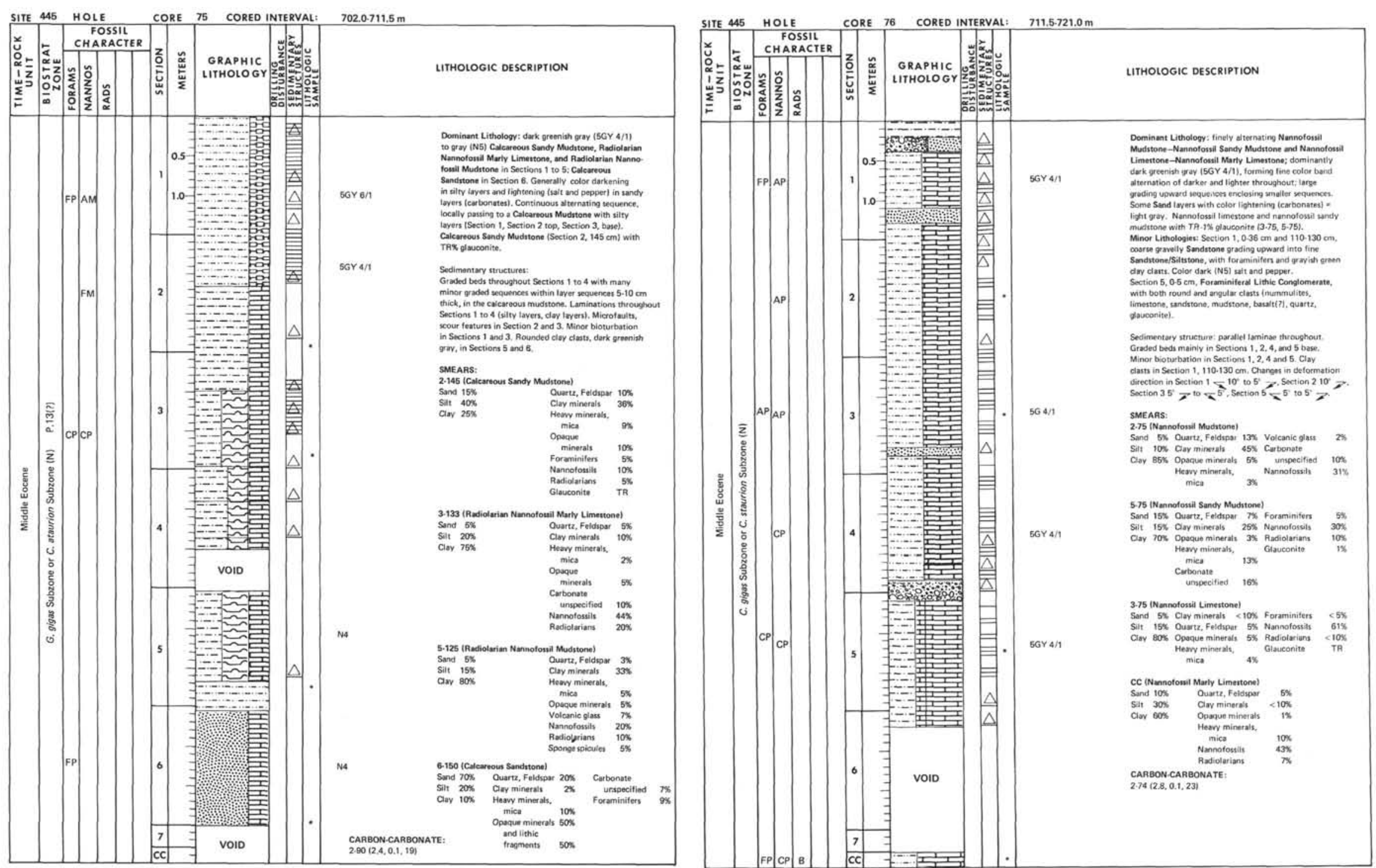

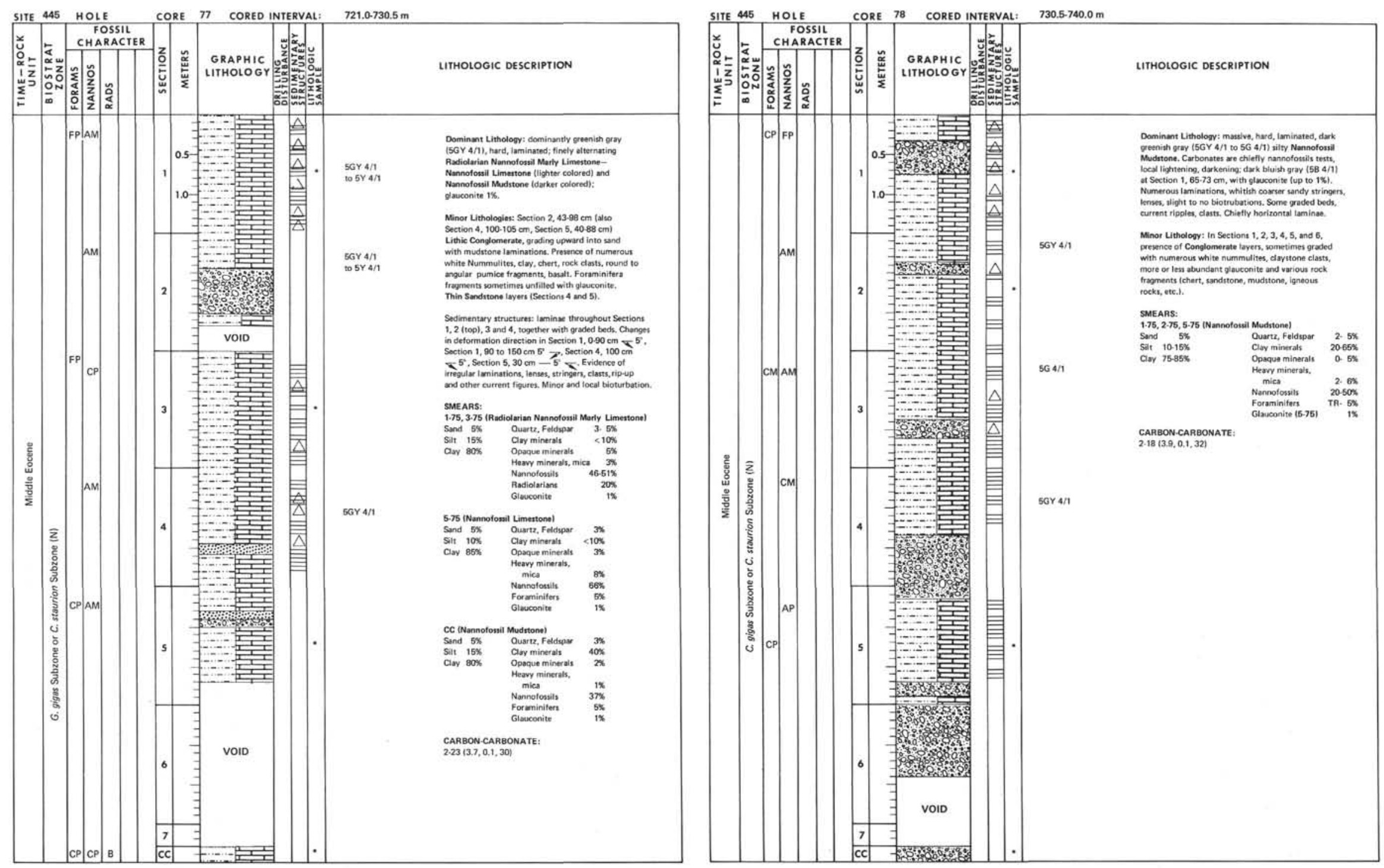

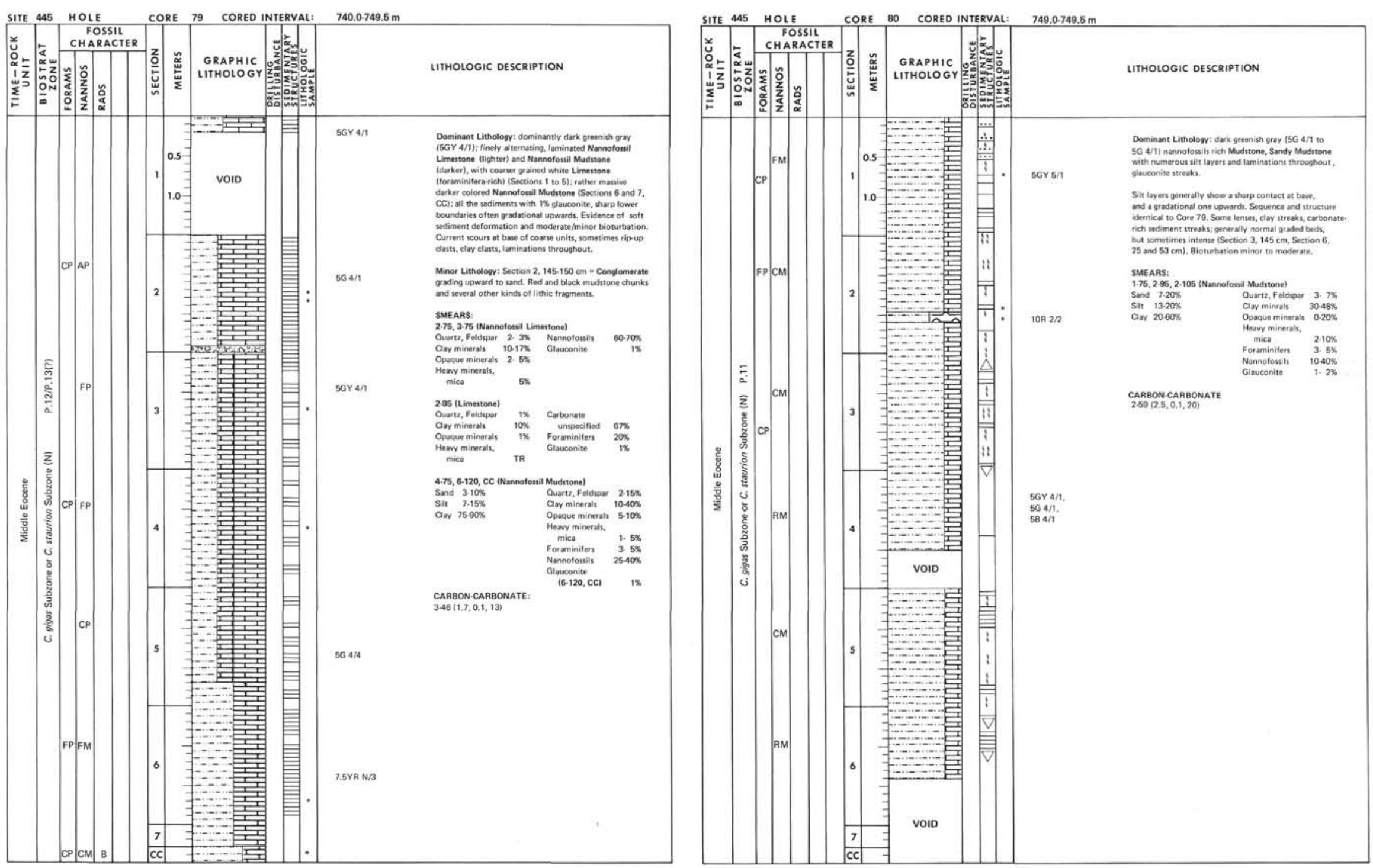


\begin{tabular}{|l|l|l|l|l|l|l|l|l|}
$\mid$ \\
SITE
\end{tabular}

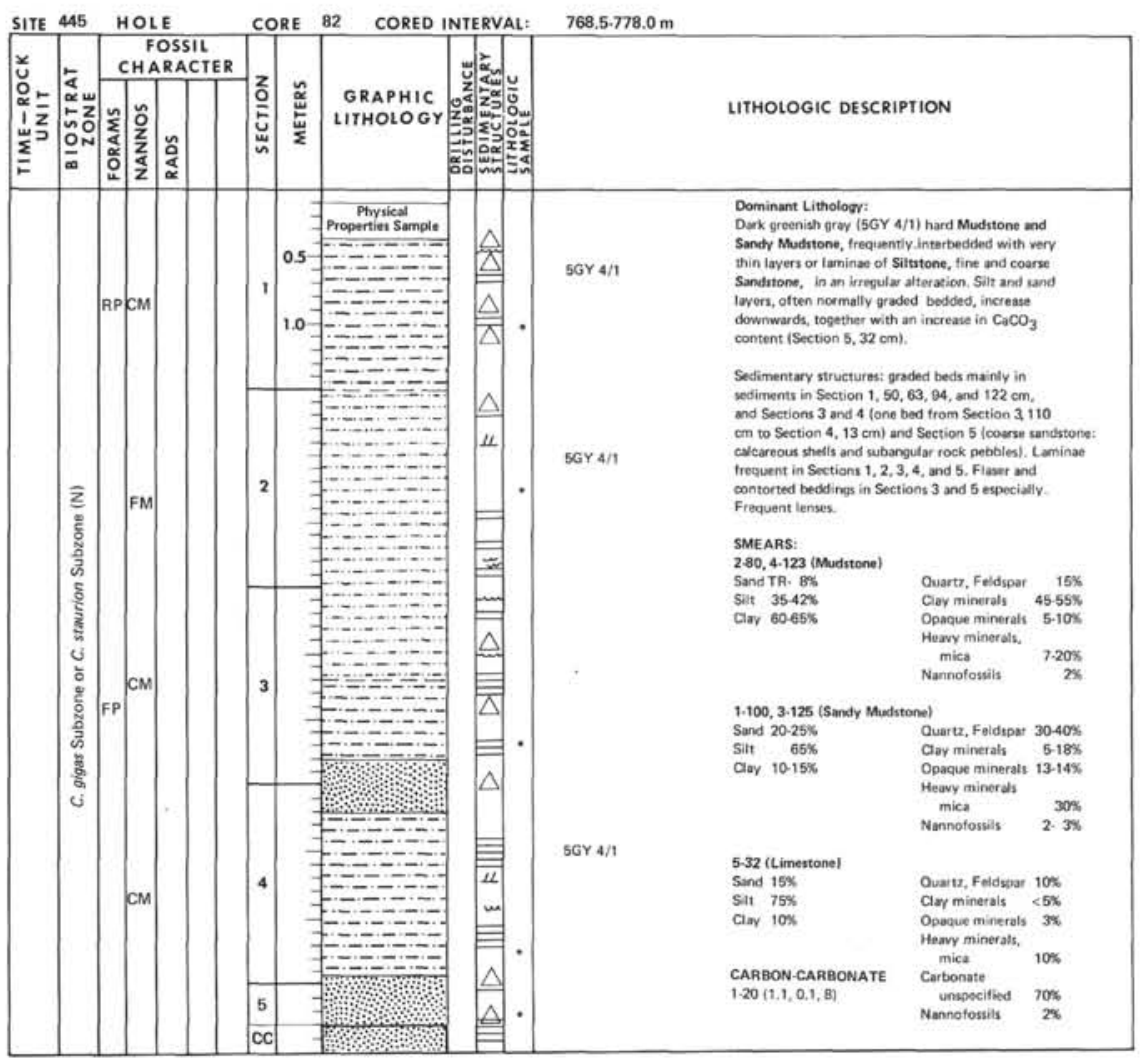




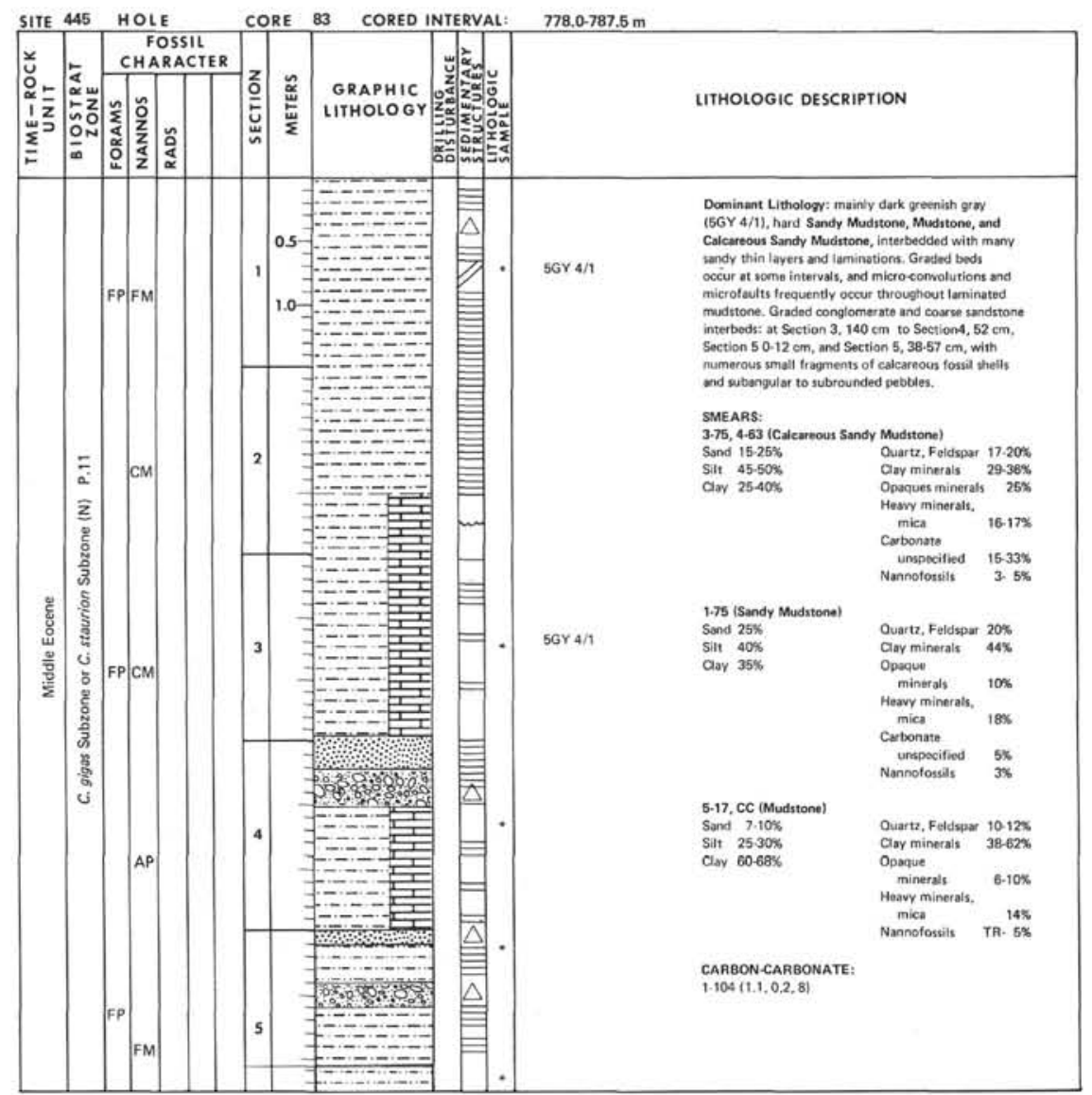

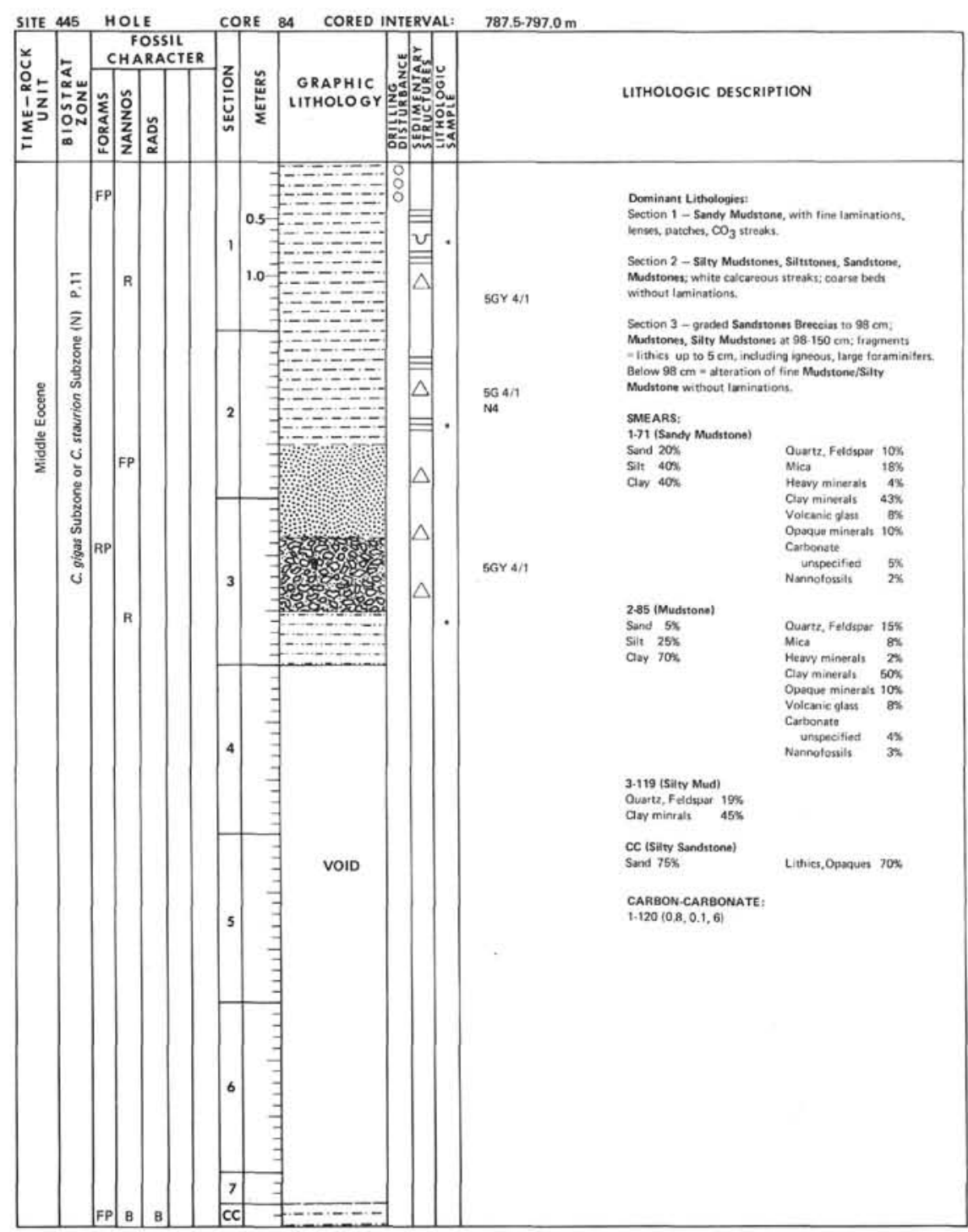




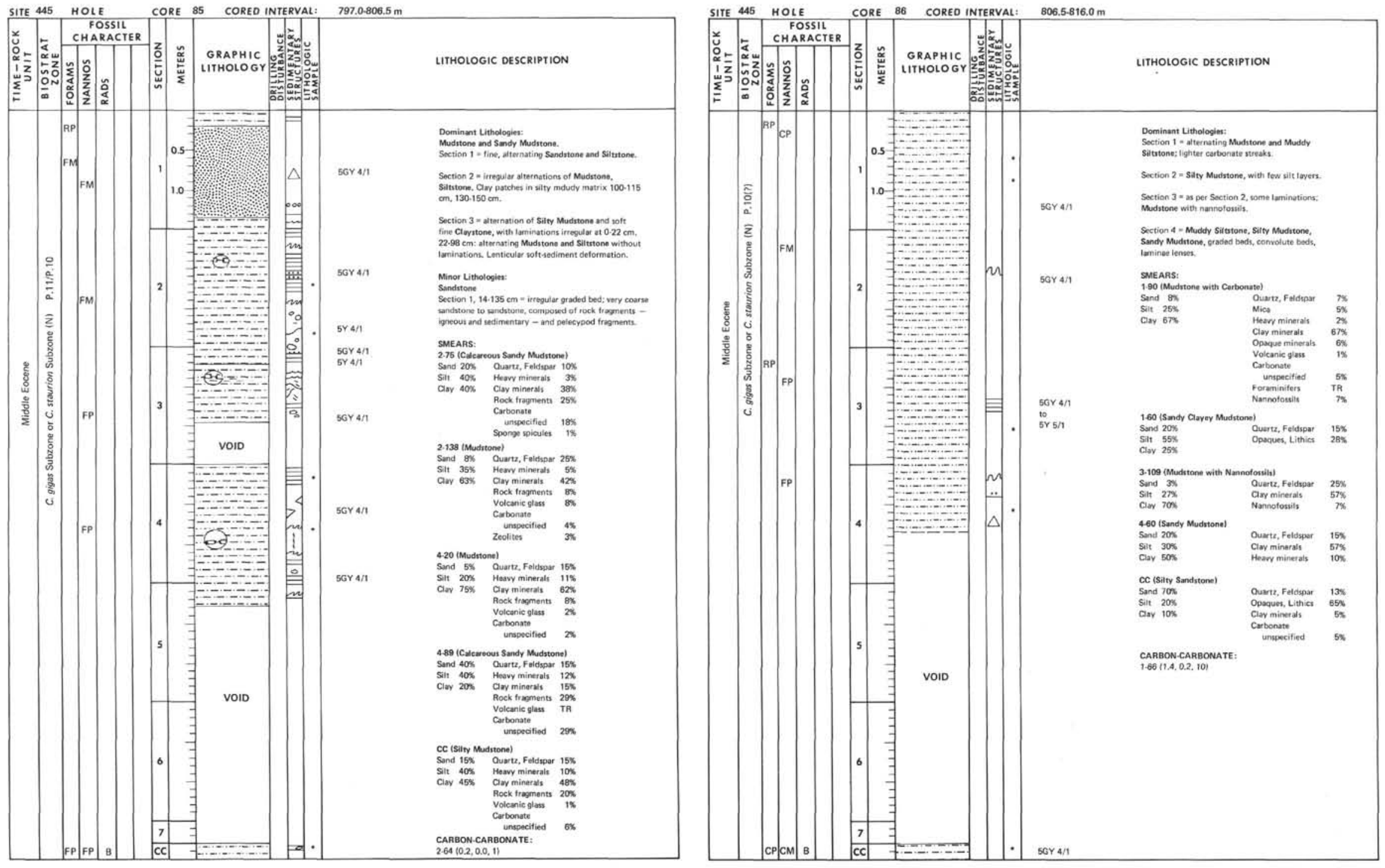



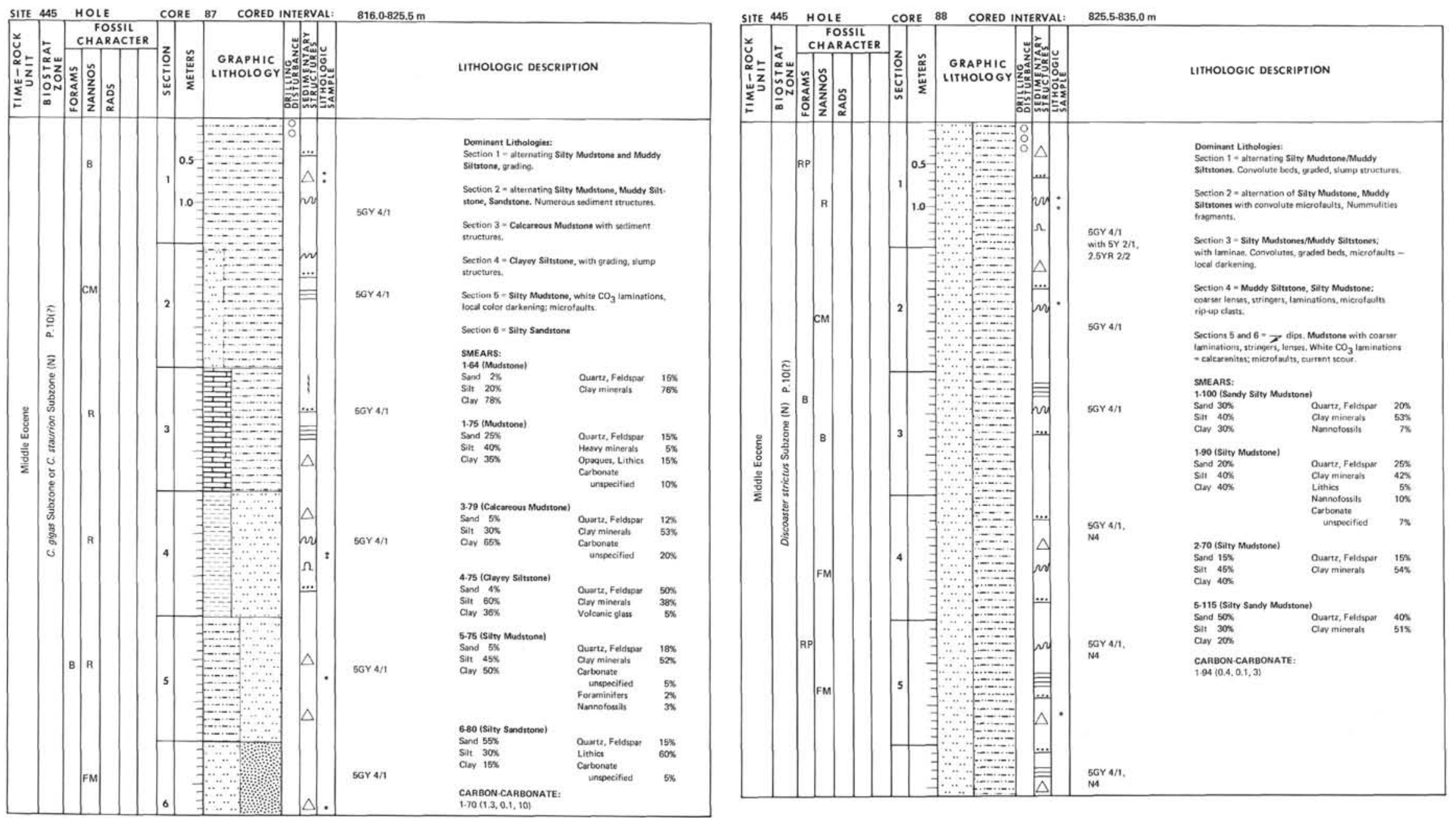

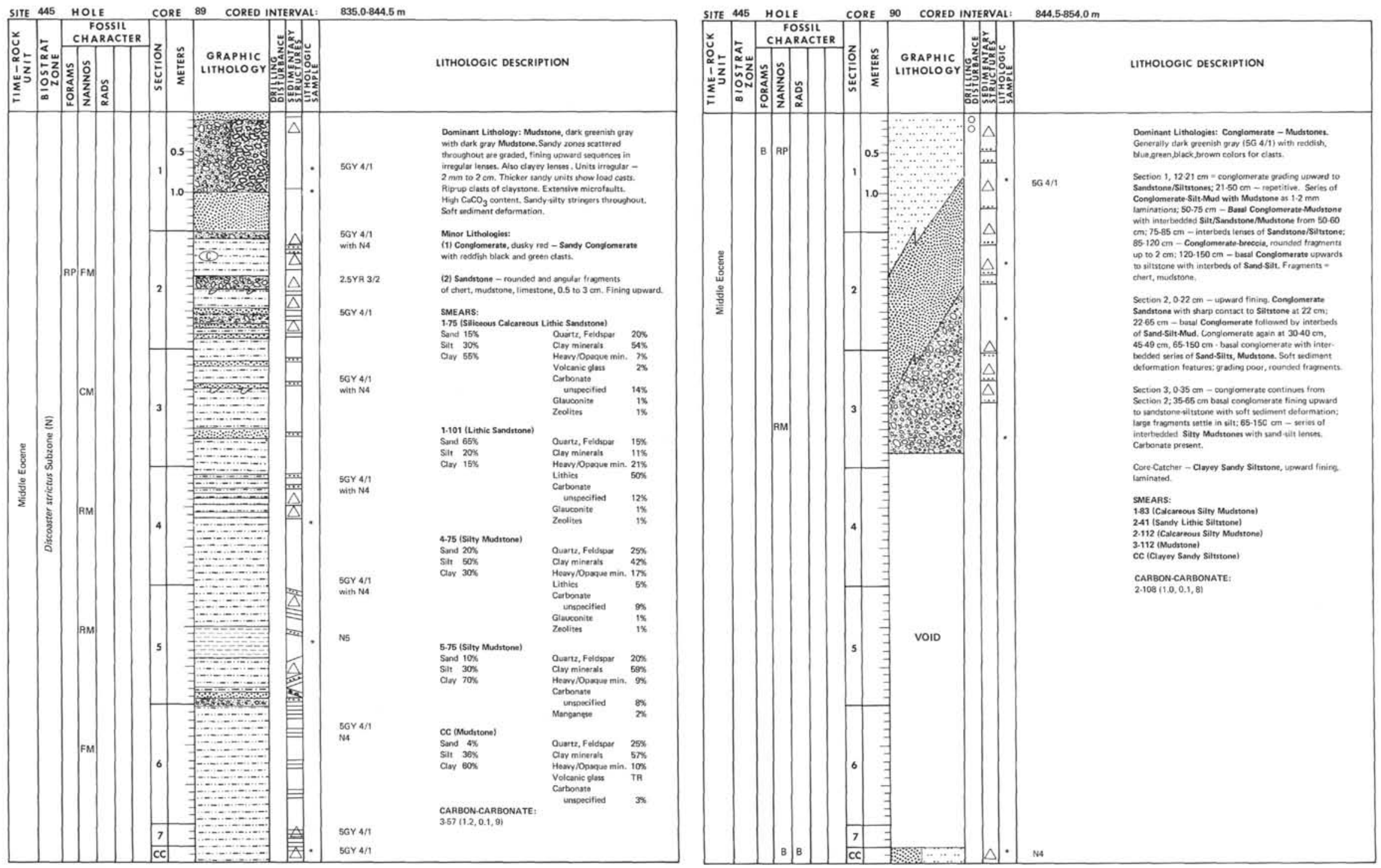


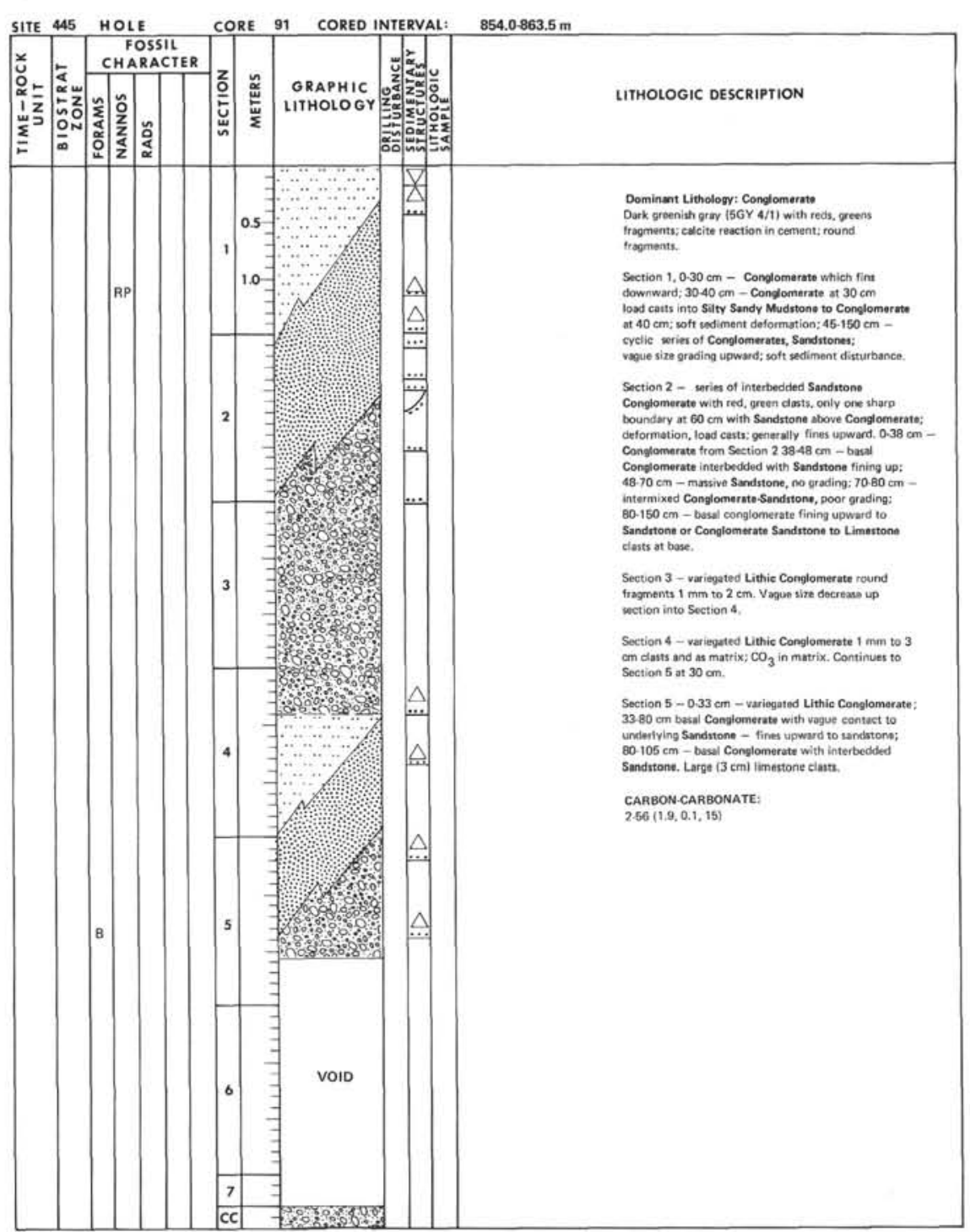

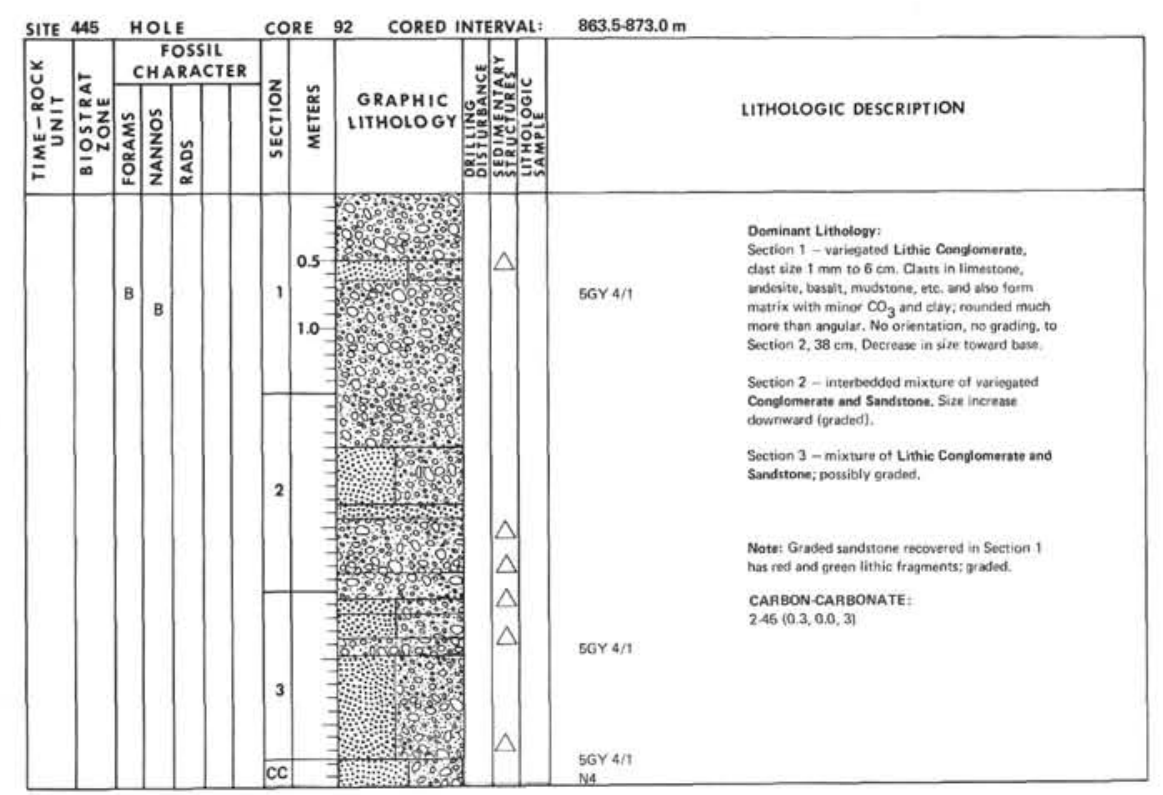




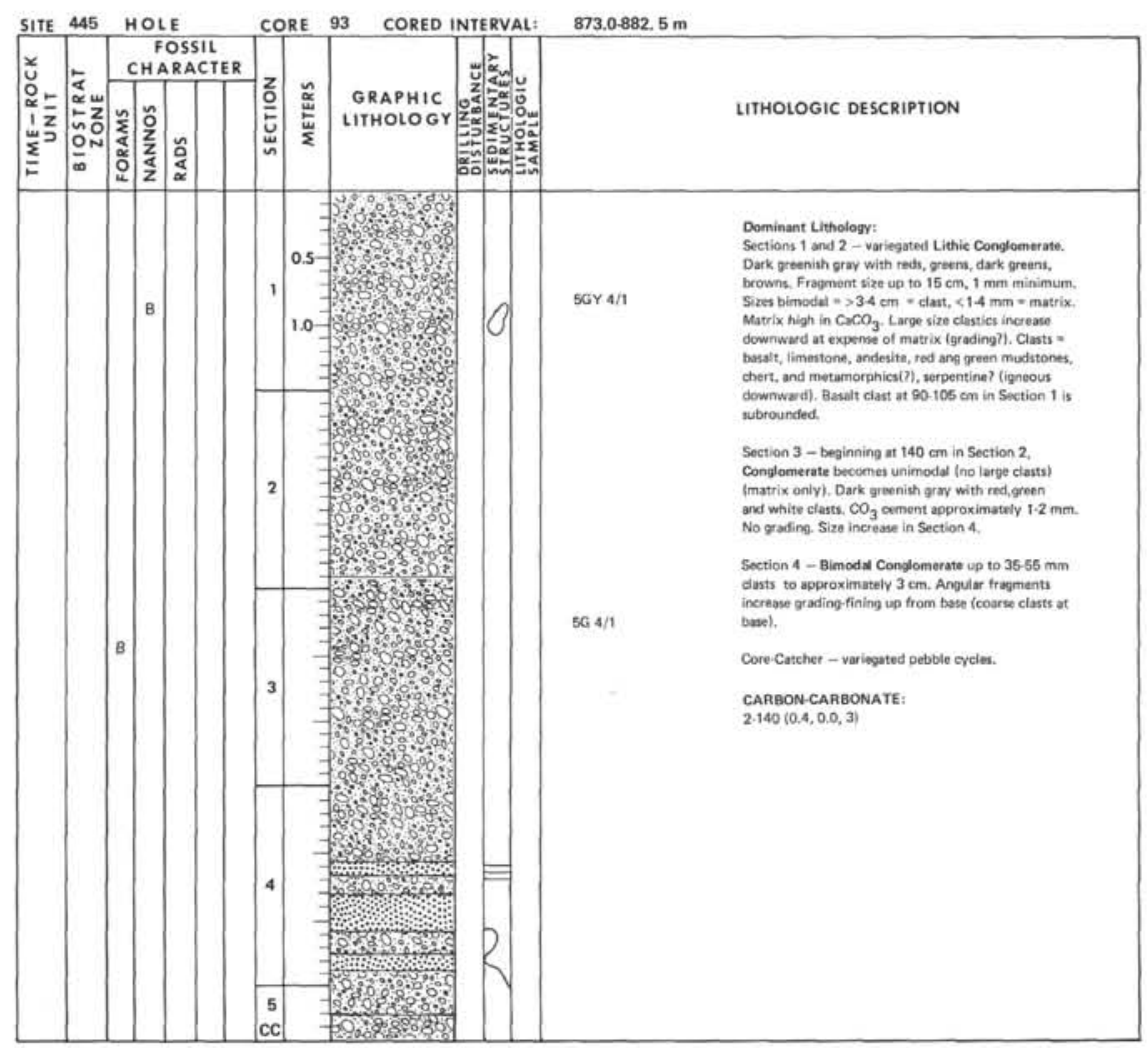

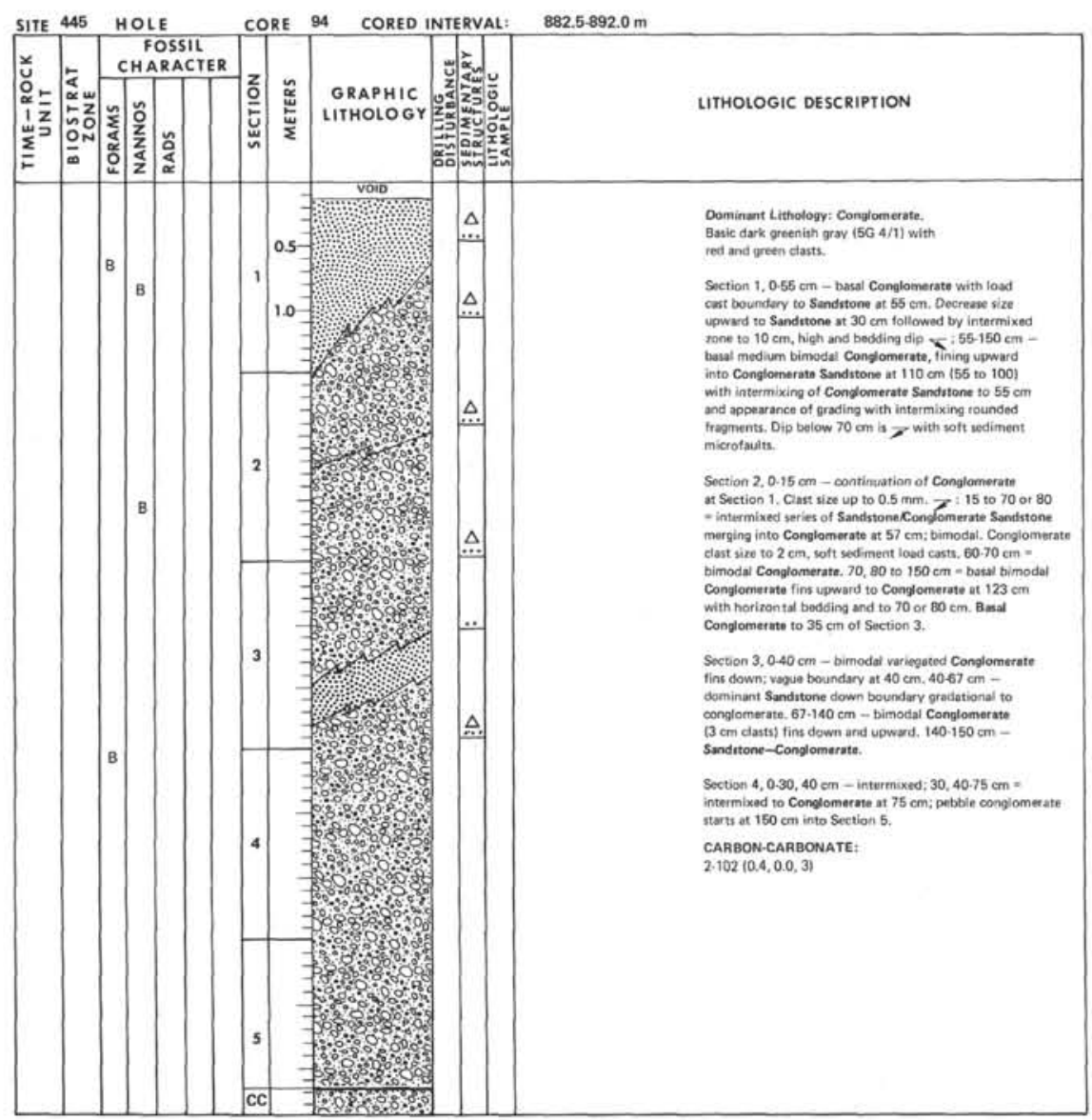




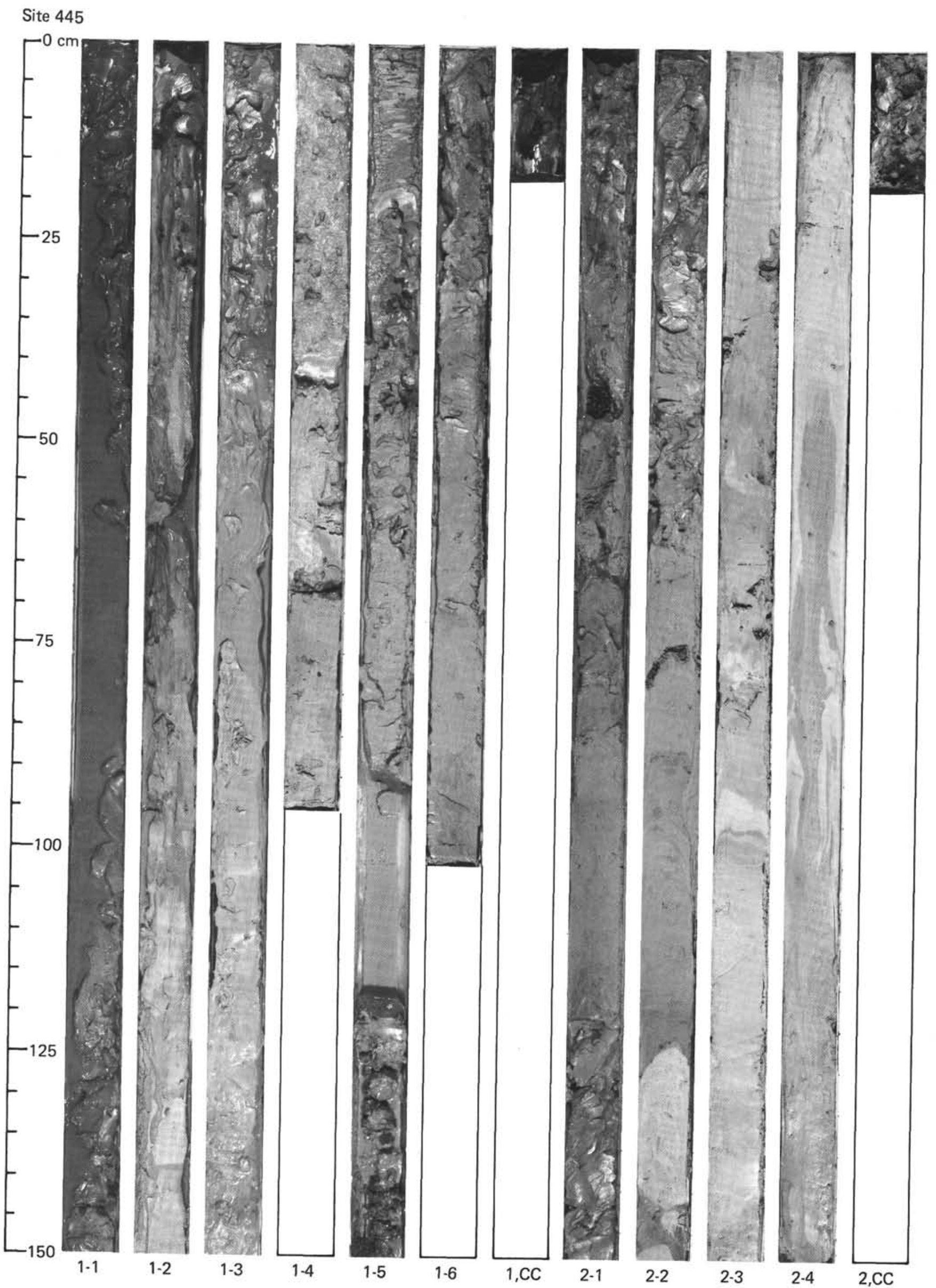




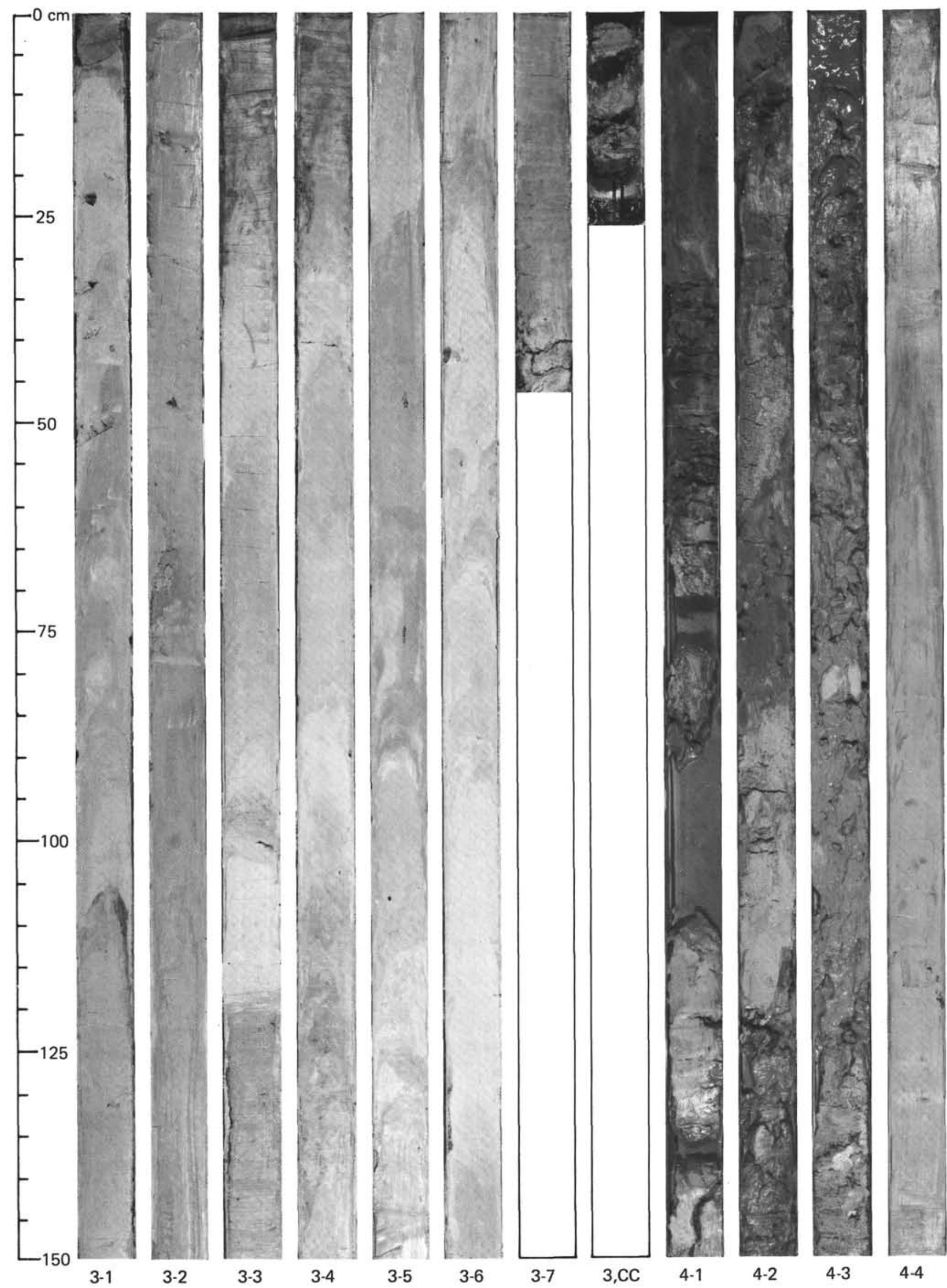


SITE 445

\section{Site 445}

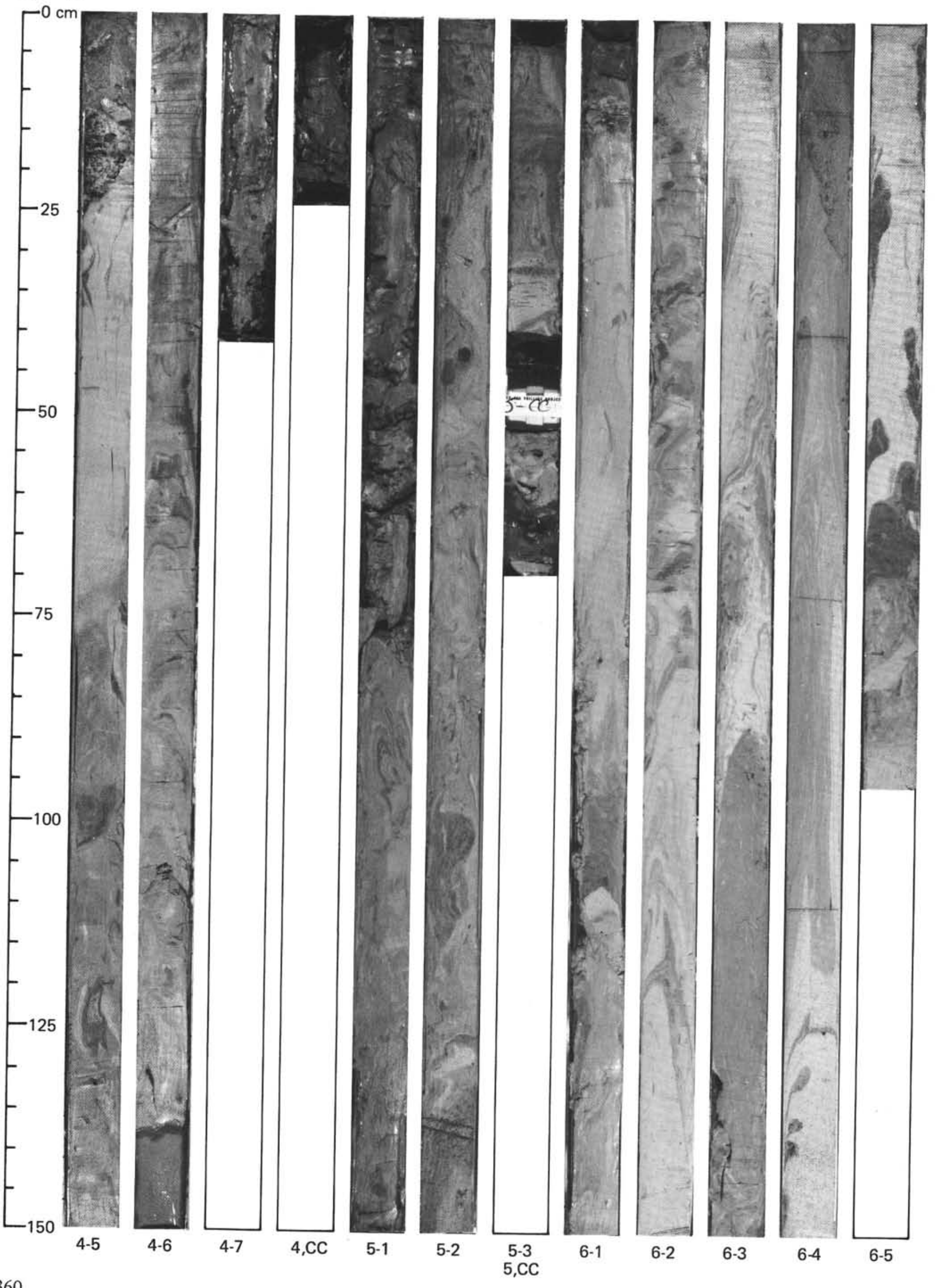


Site 445

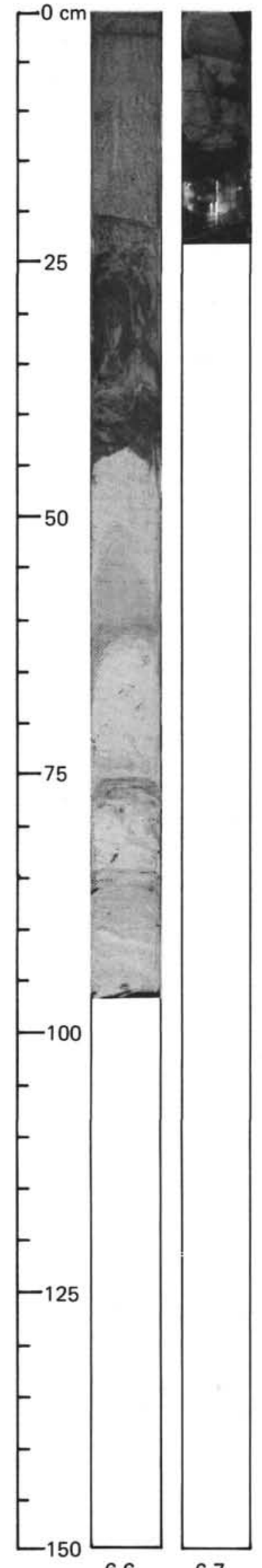

6-6
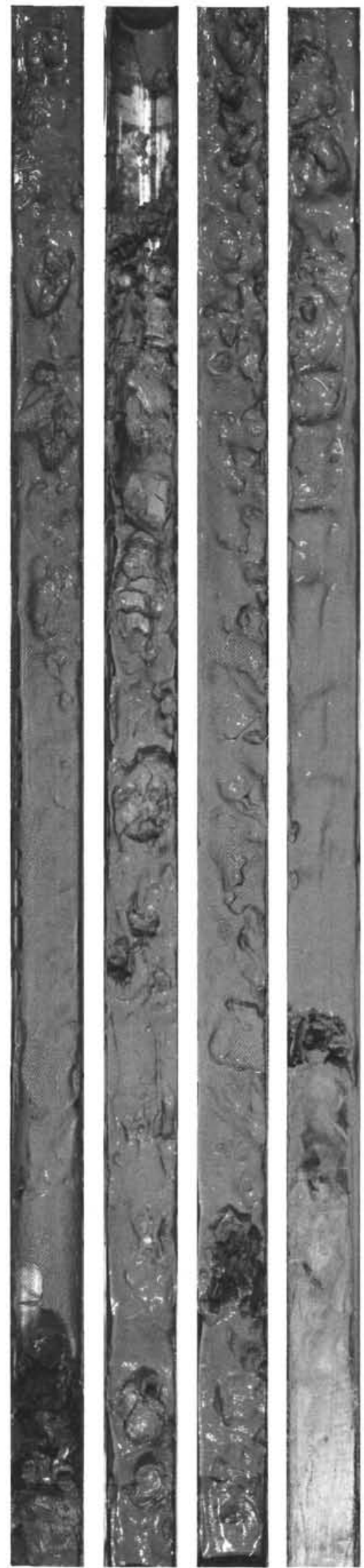

7-4

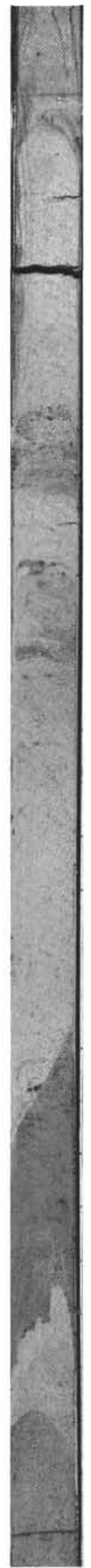

7-5
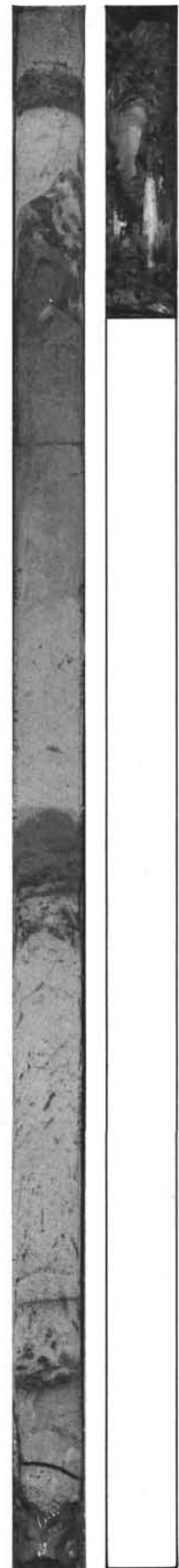

7-6 7.CC

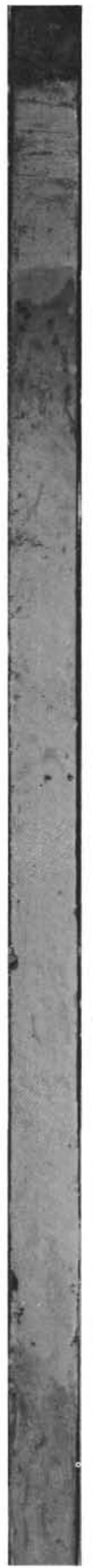

8-1

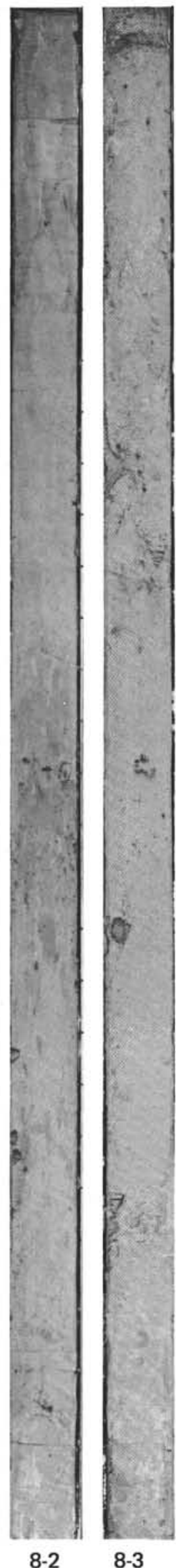




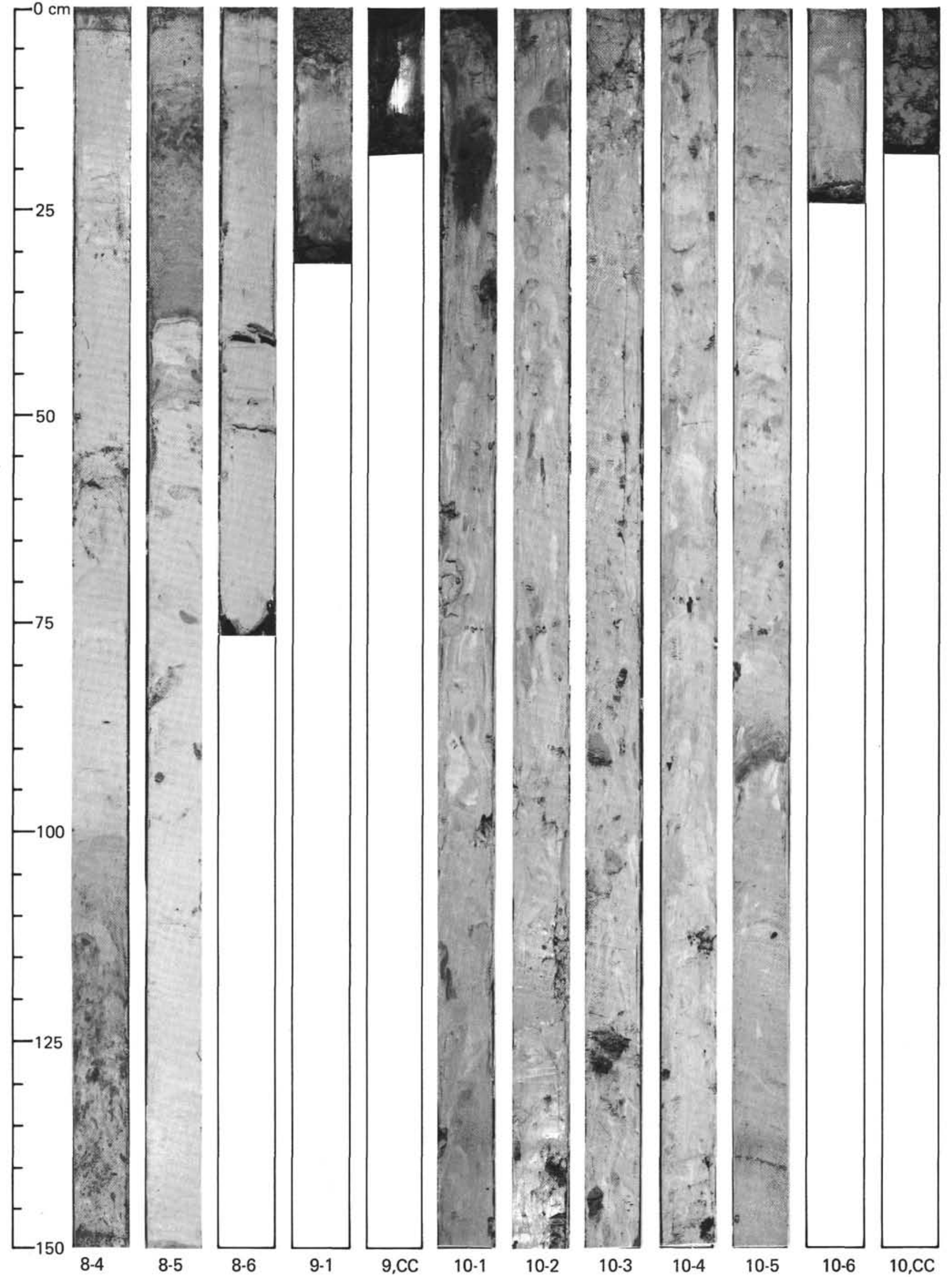


Site 445

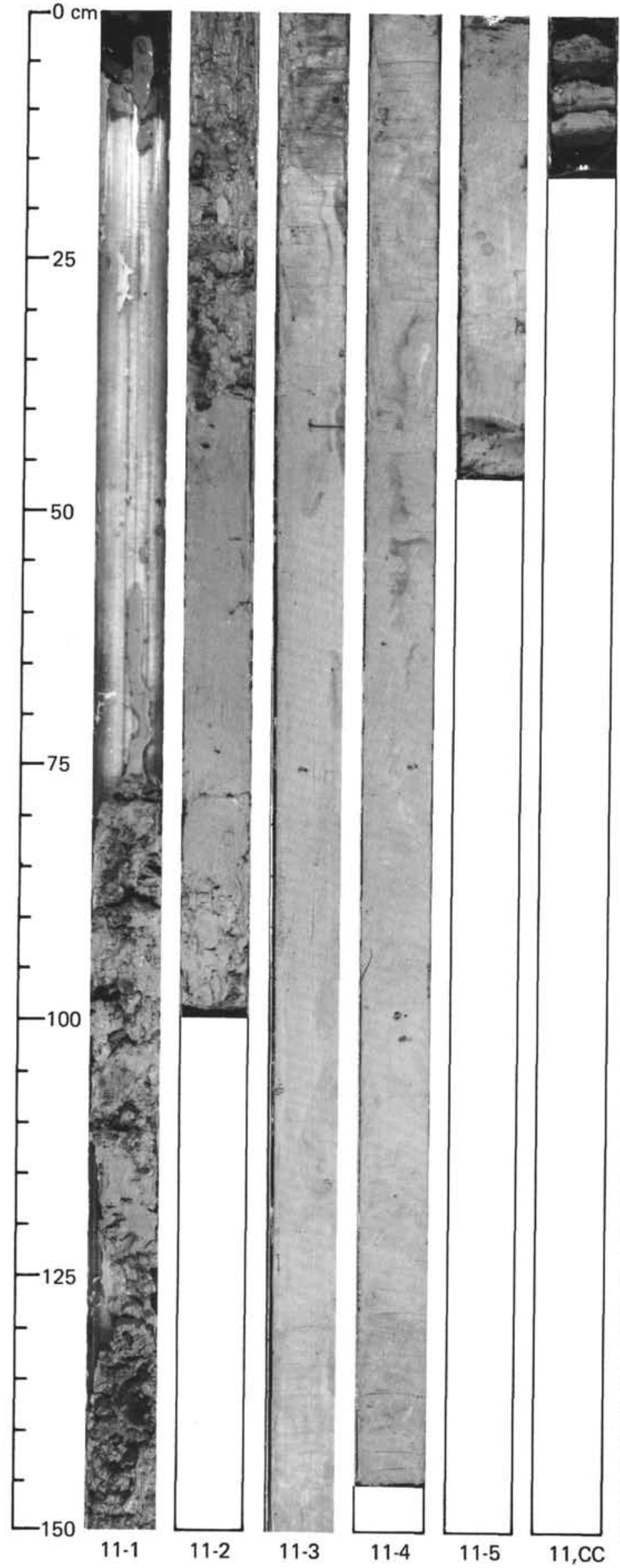

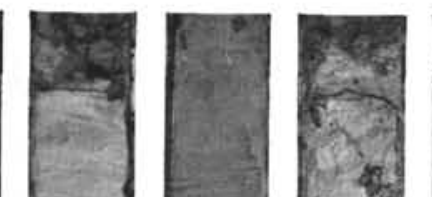
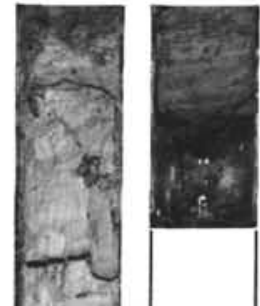

3

3

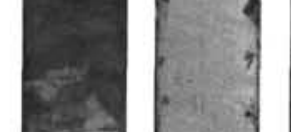

$[1$

1.9

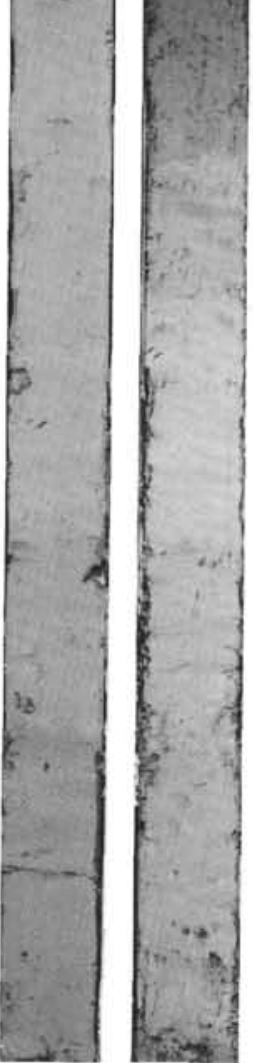

$12-1$

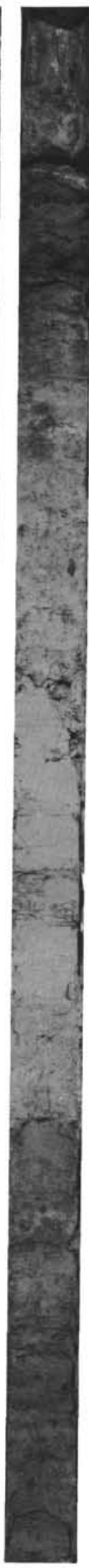



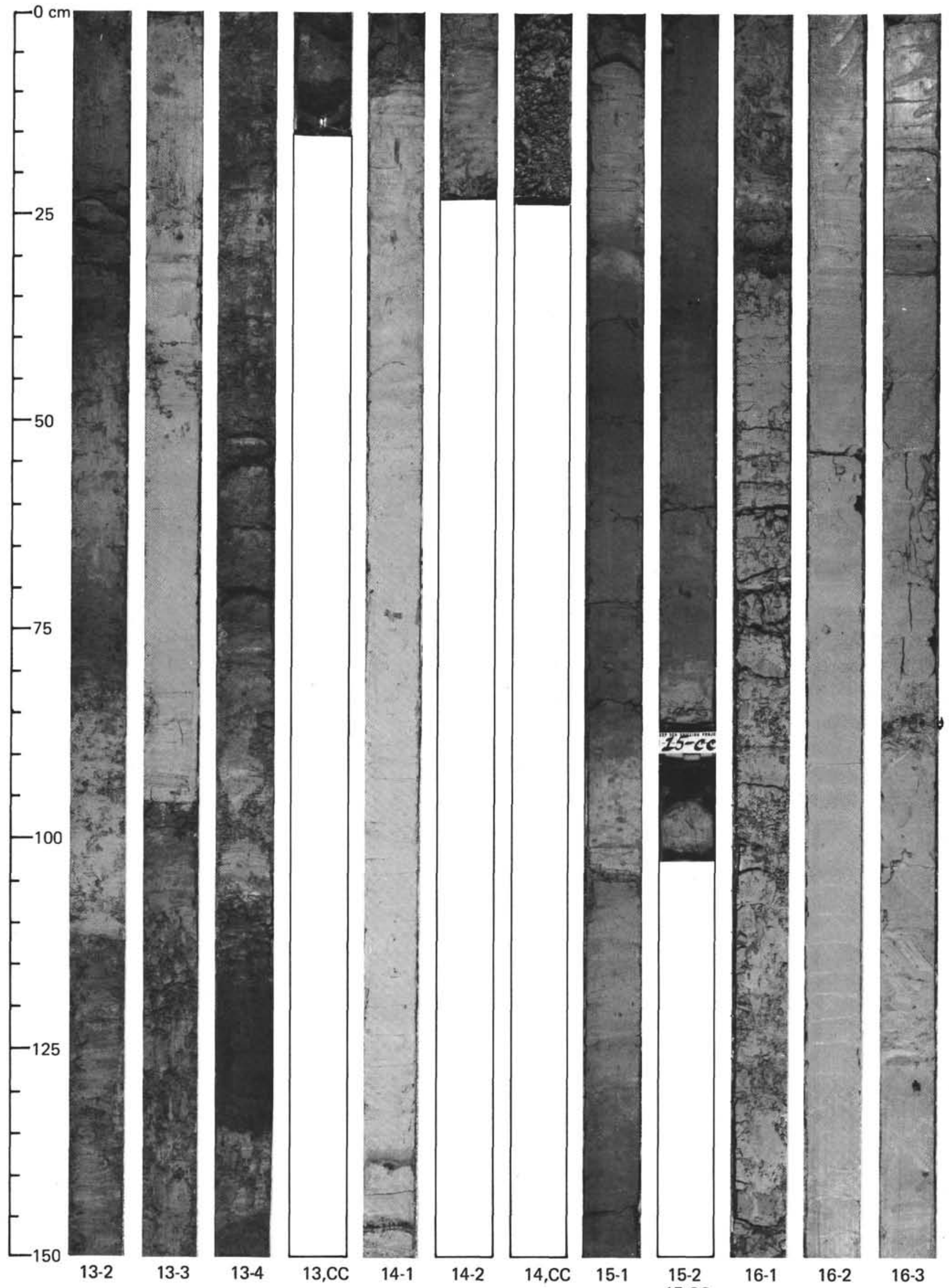
Site 445
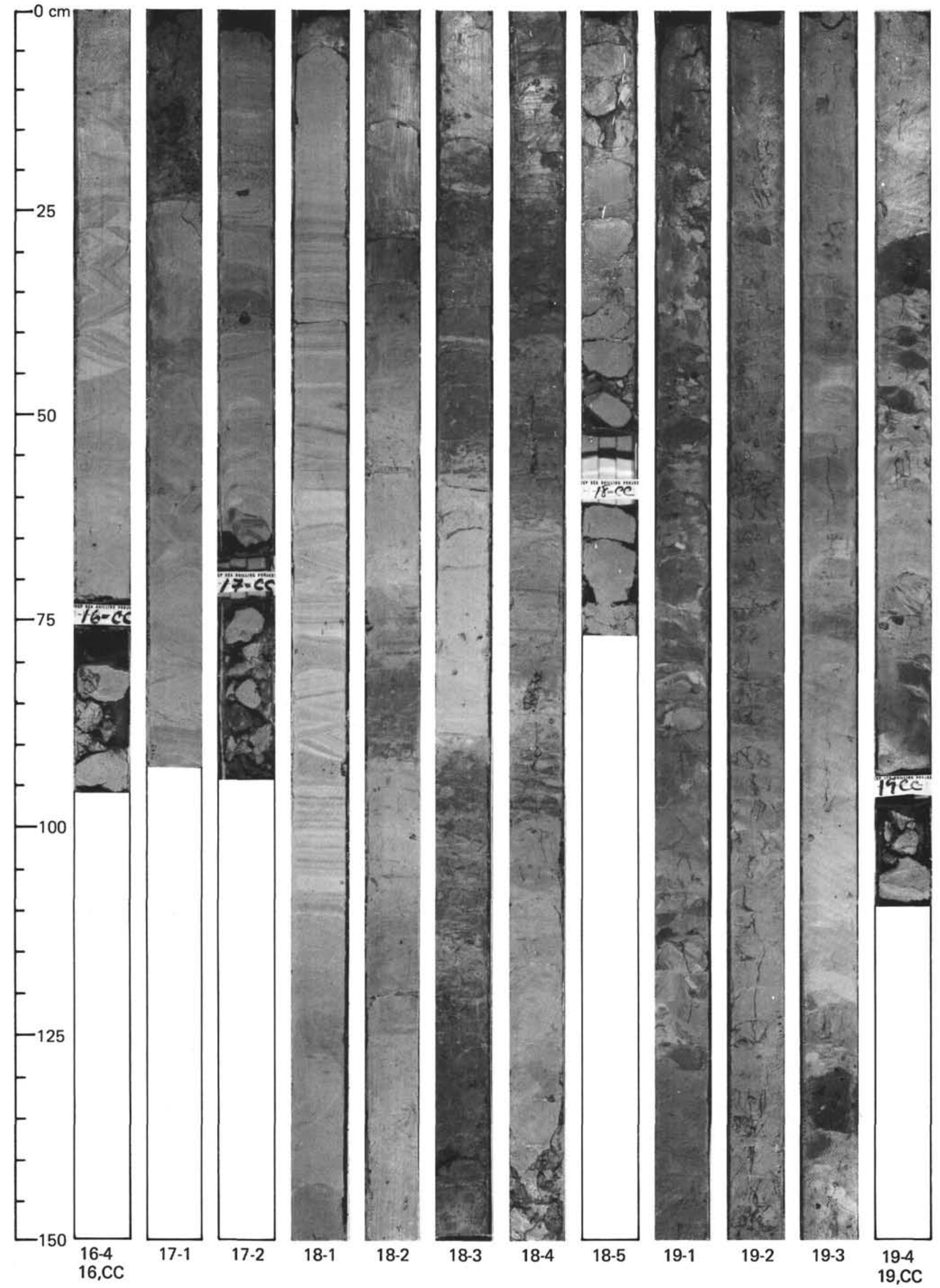


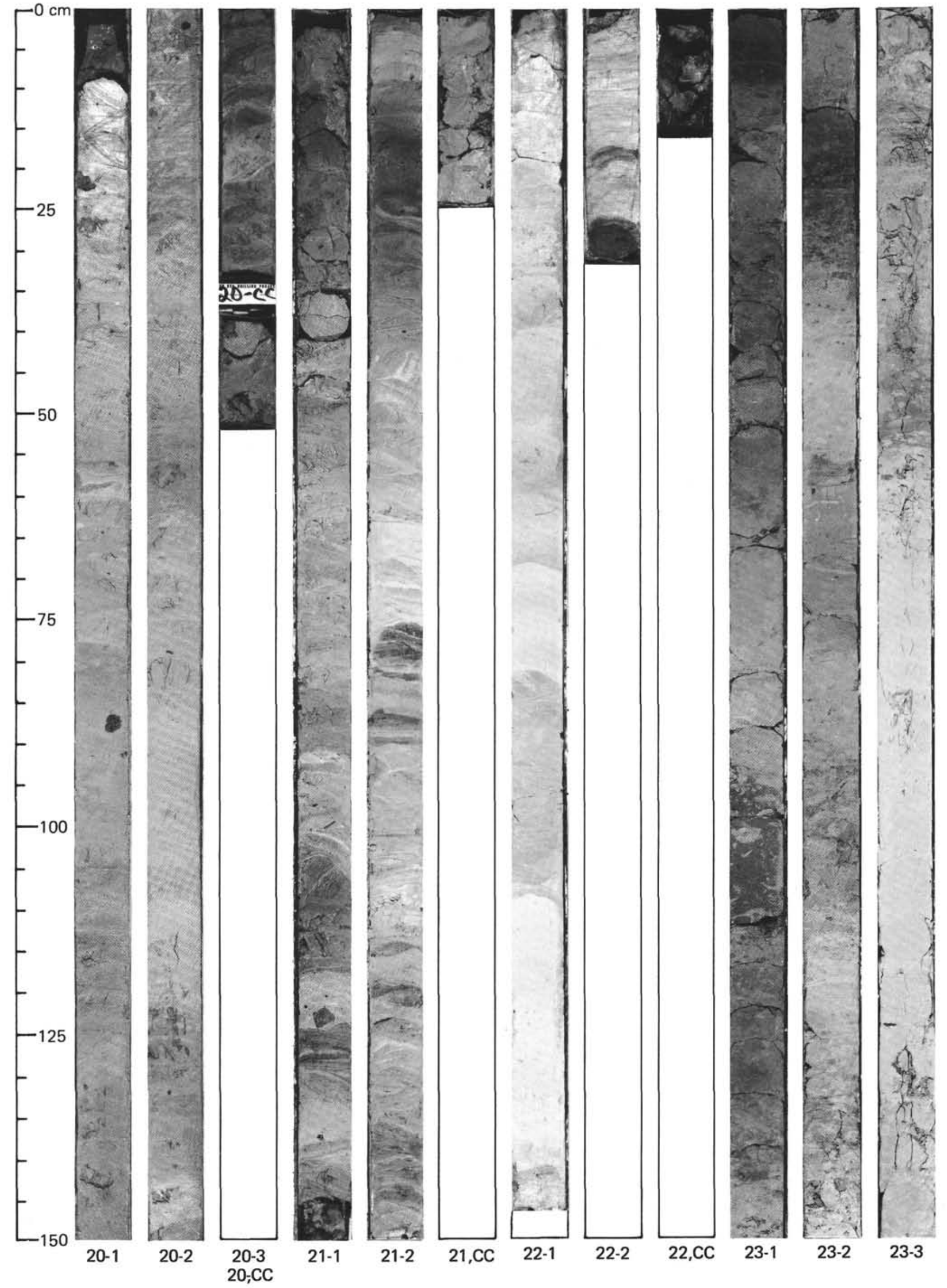




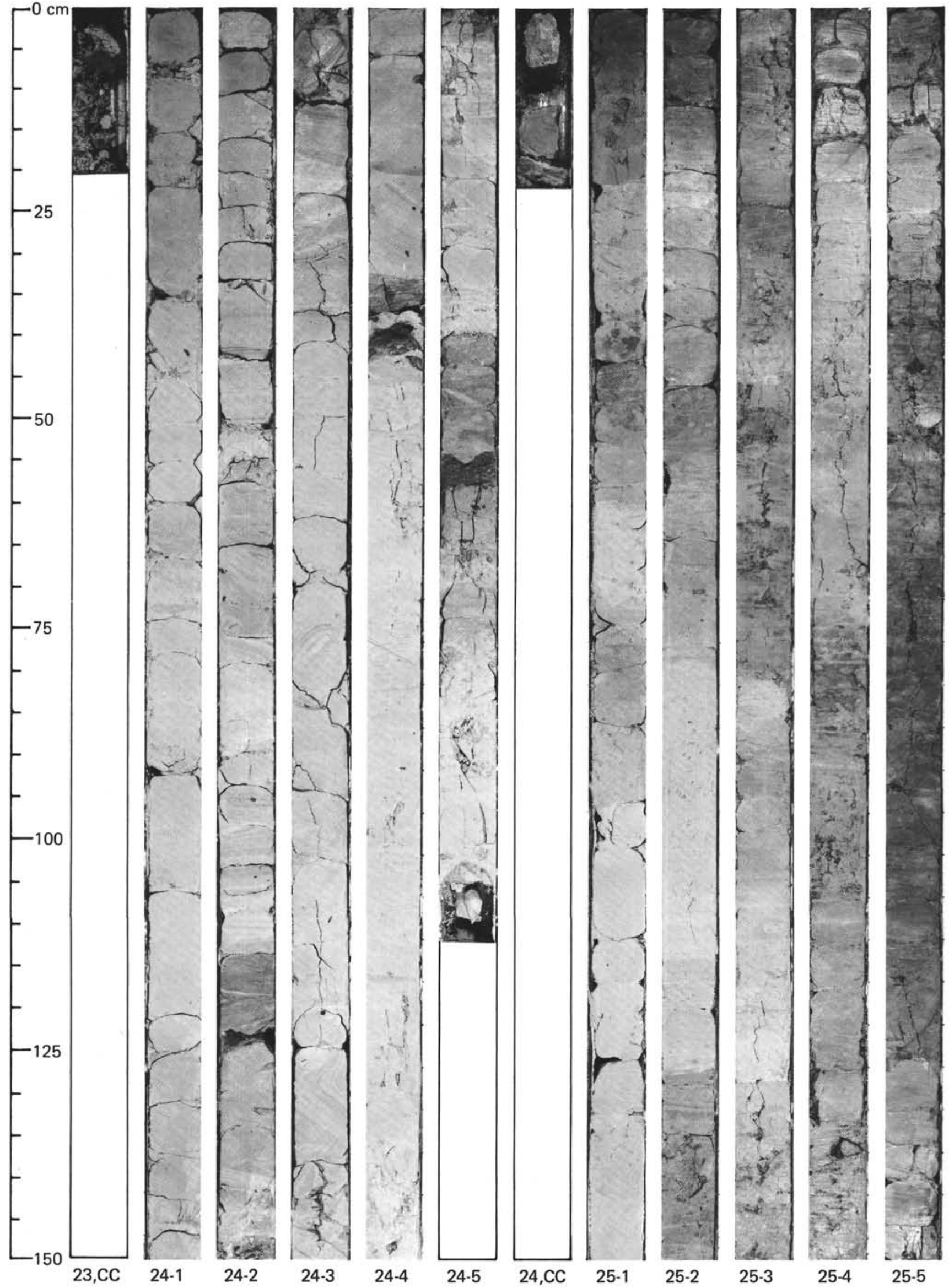




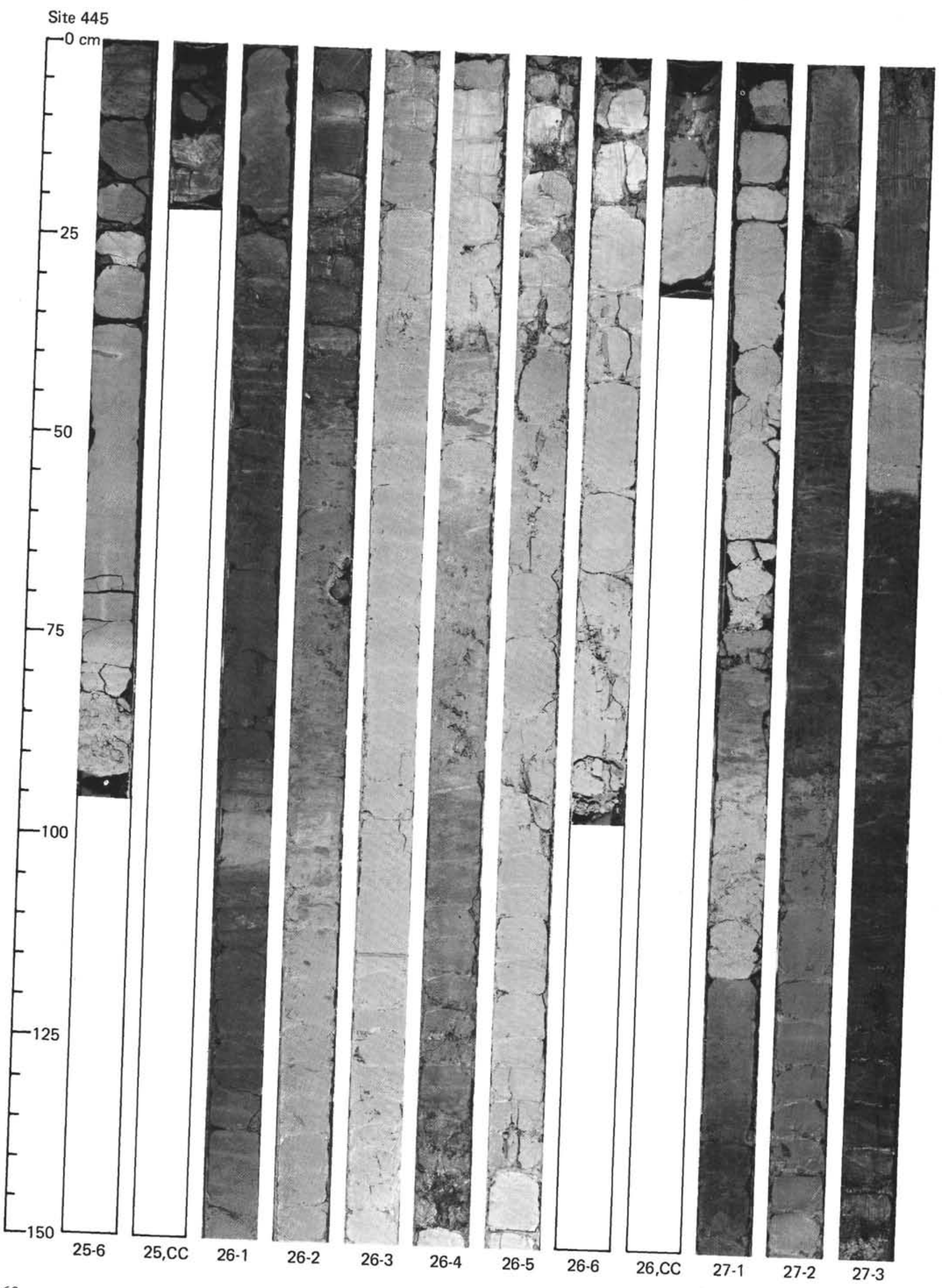


Site 445

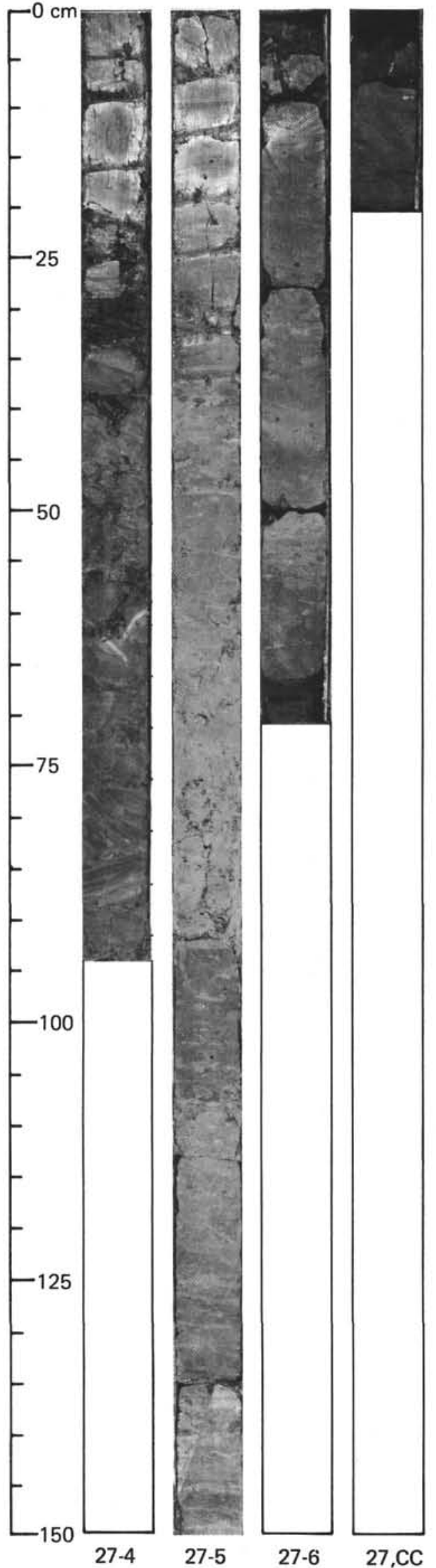

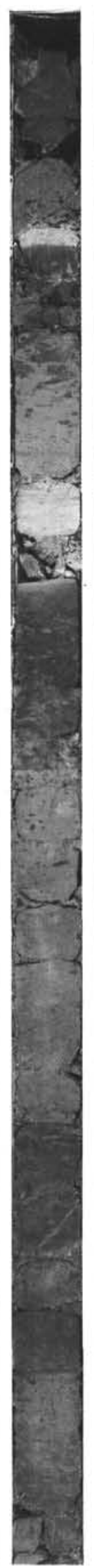

28-1
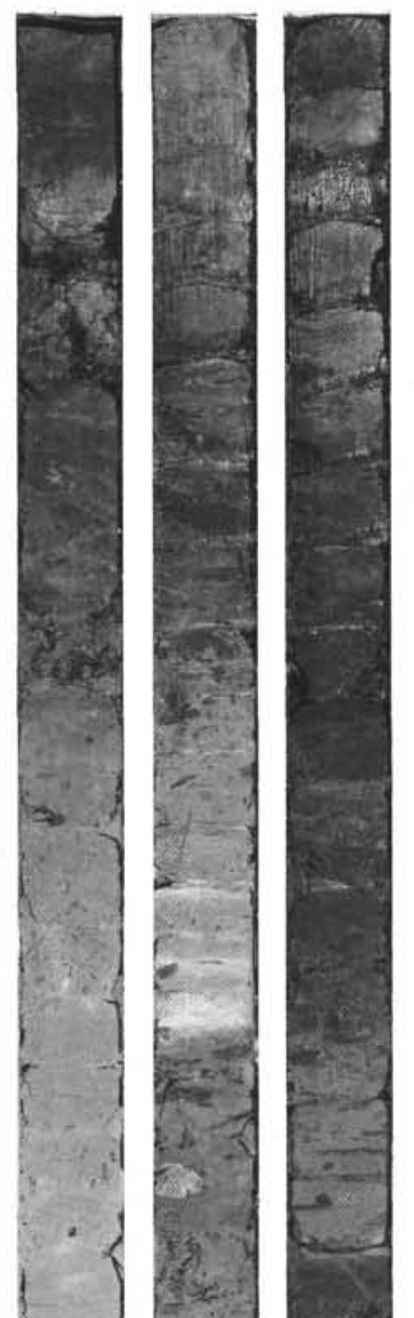

ह

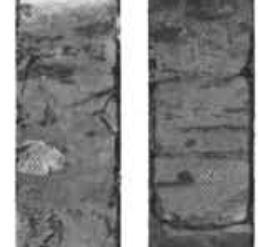

政
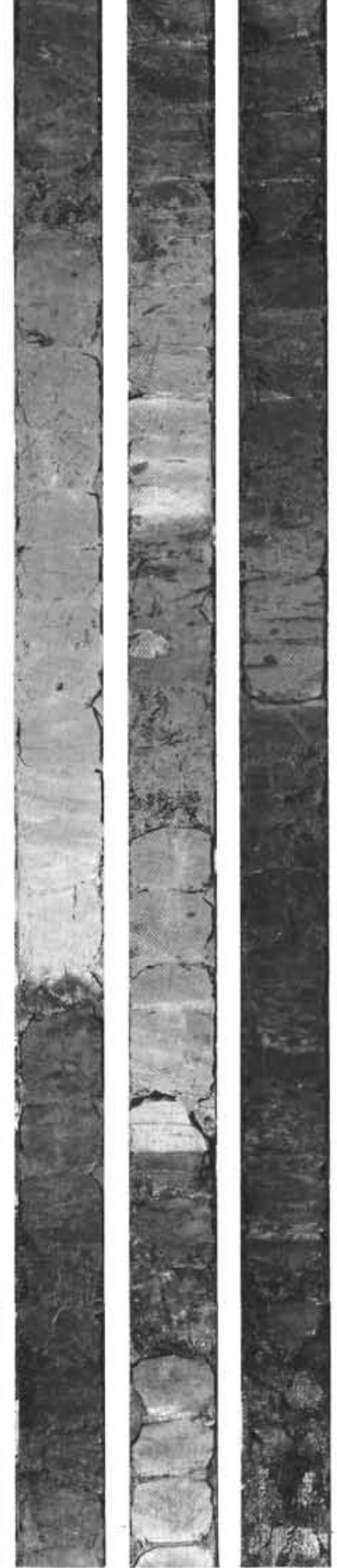

28-3
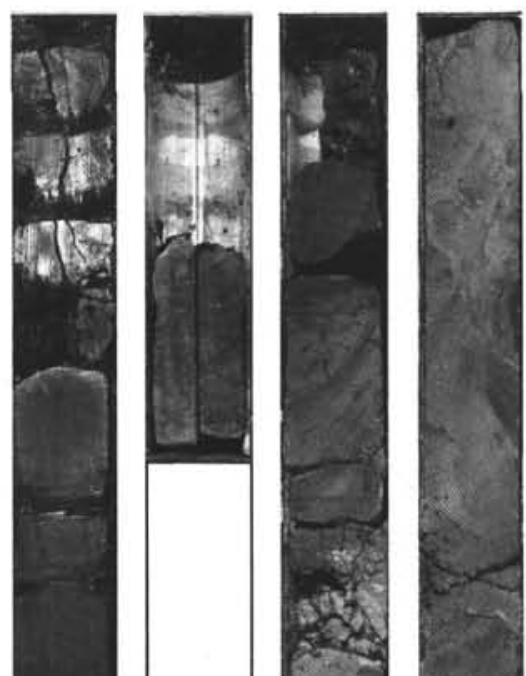

है

c.

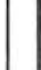

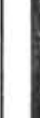

. 


\section{Site 445}

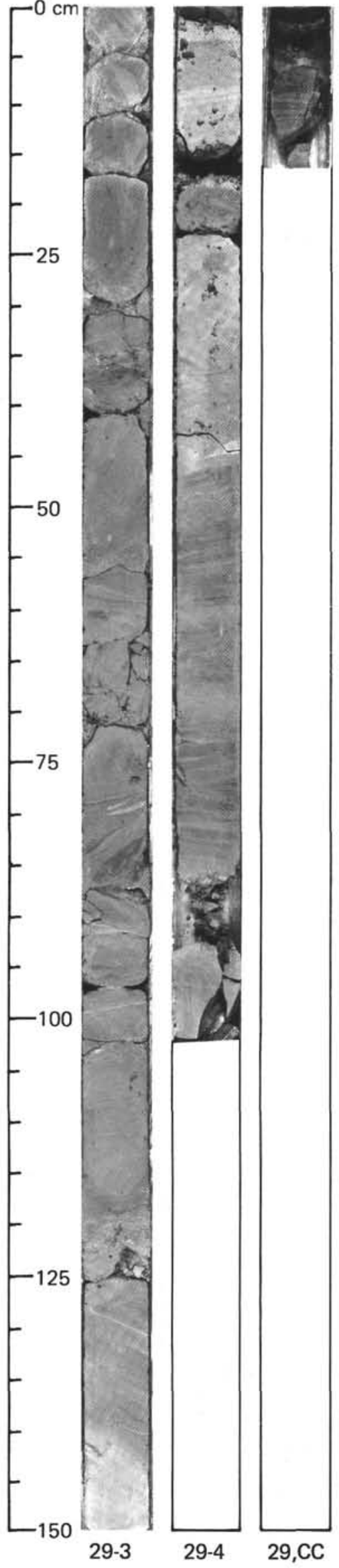

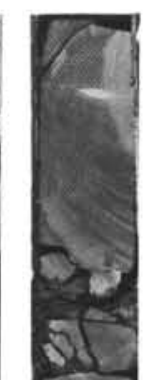

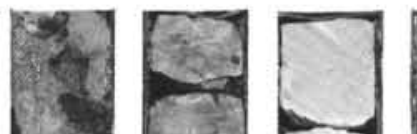

Sis
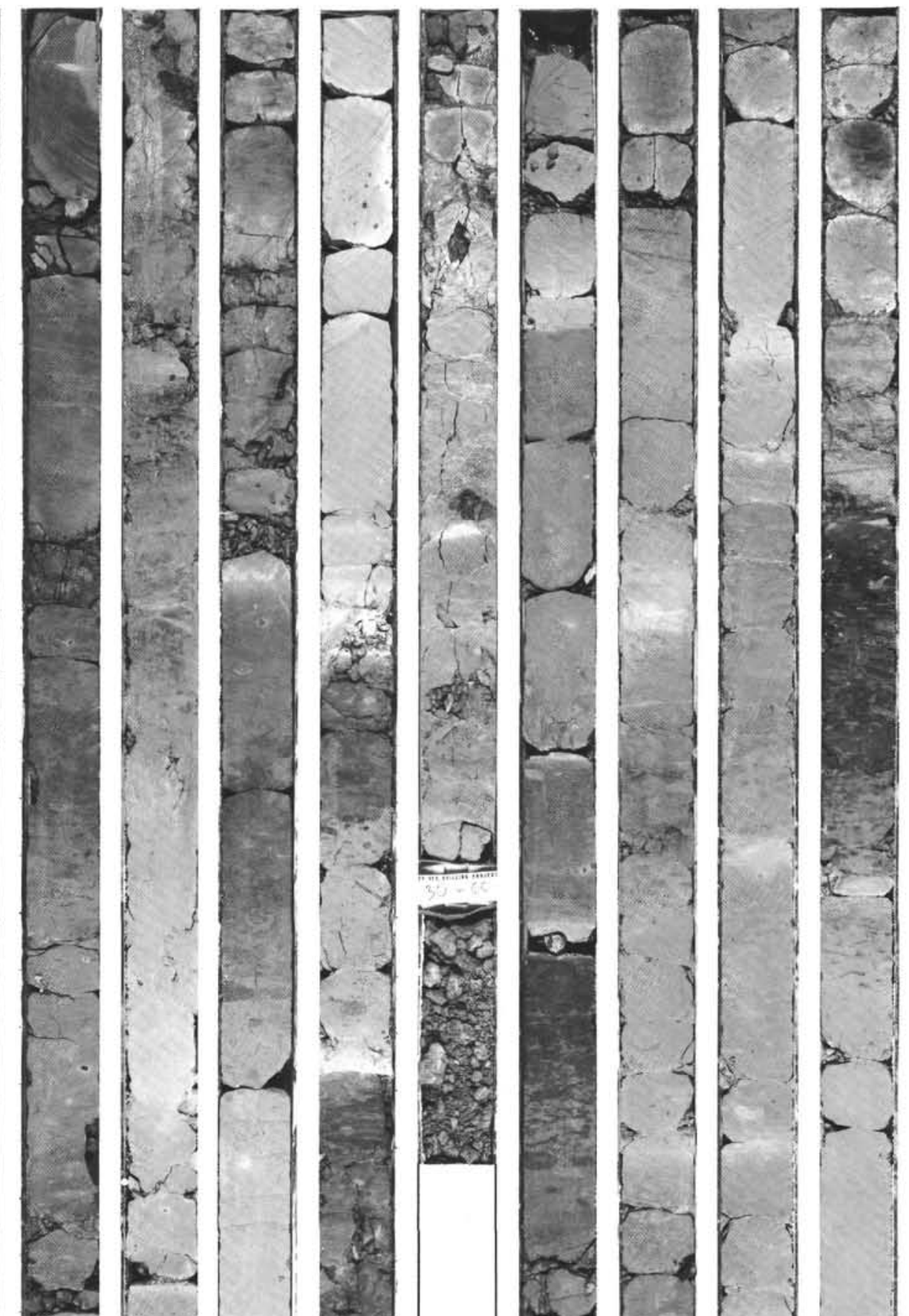

1. $\quad$ है
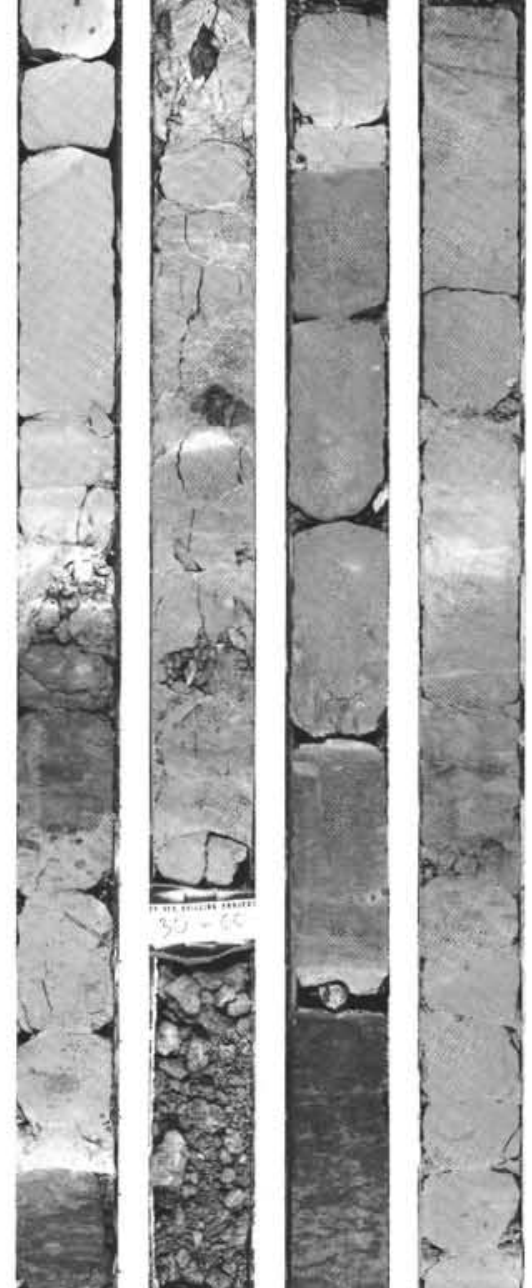

r
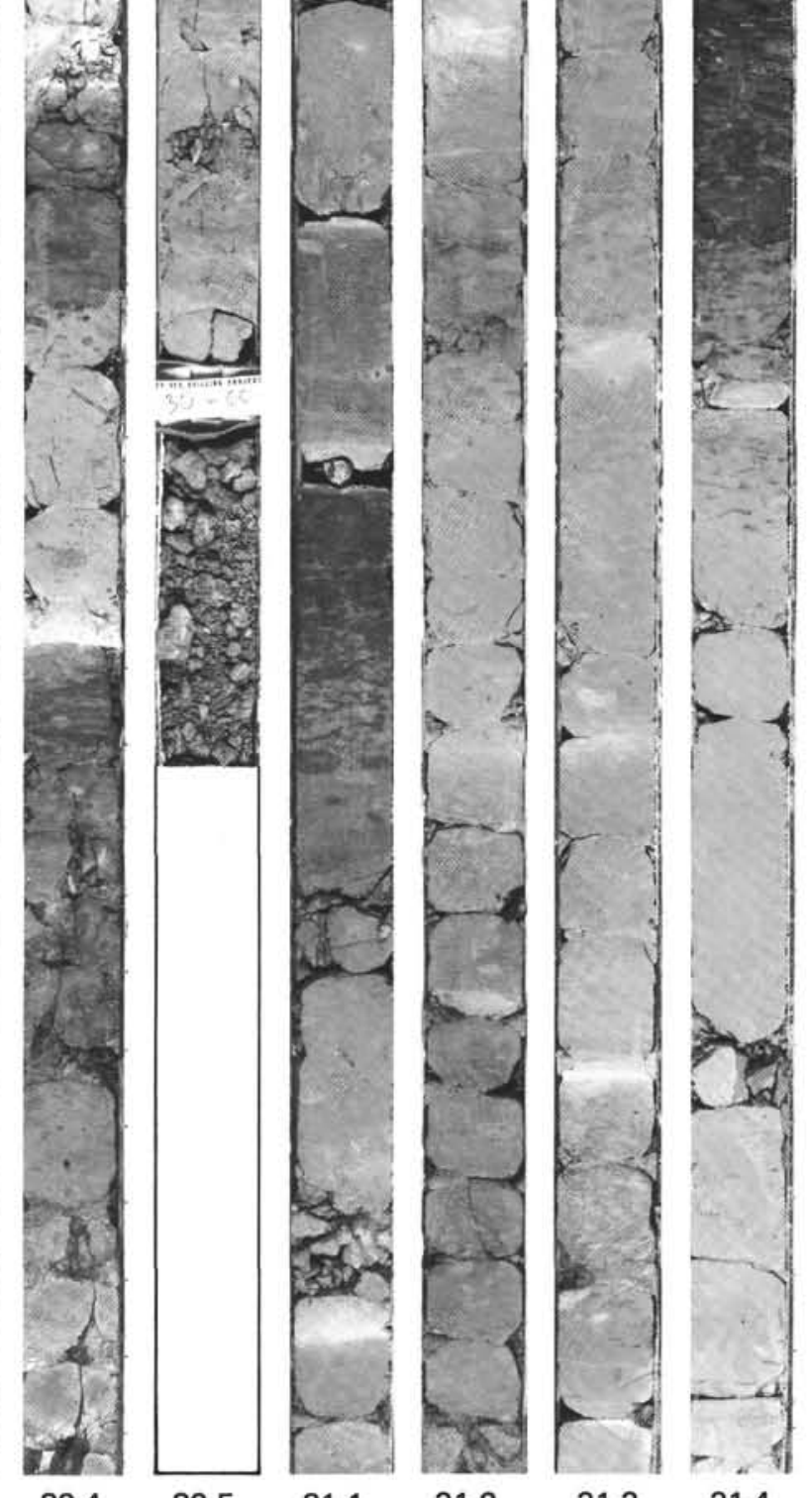

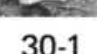

$30-2$

30-3

$30, \mathrm{CC}$

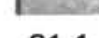

31-1 31-2 
Site 445

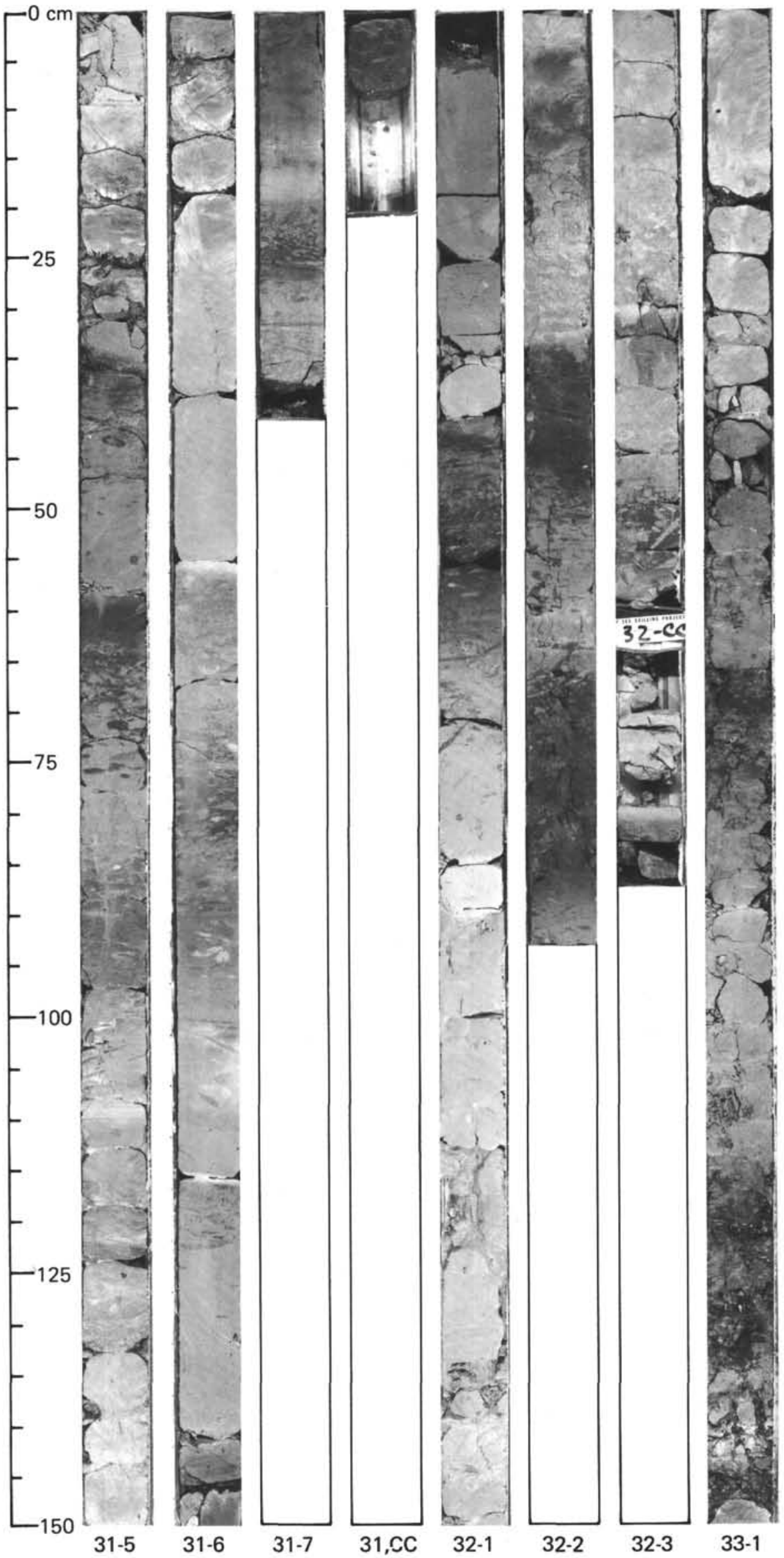

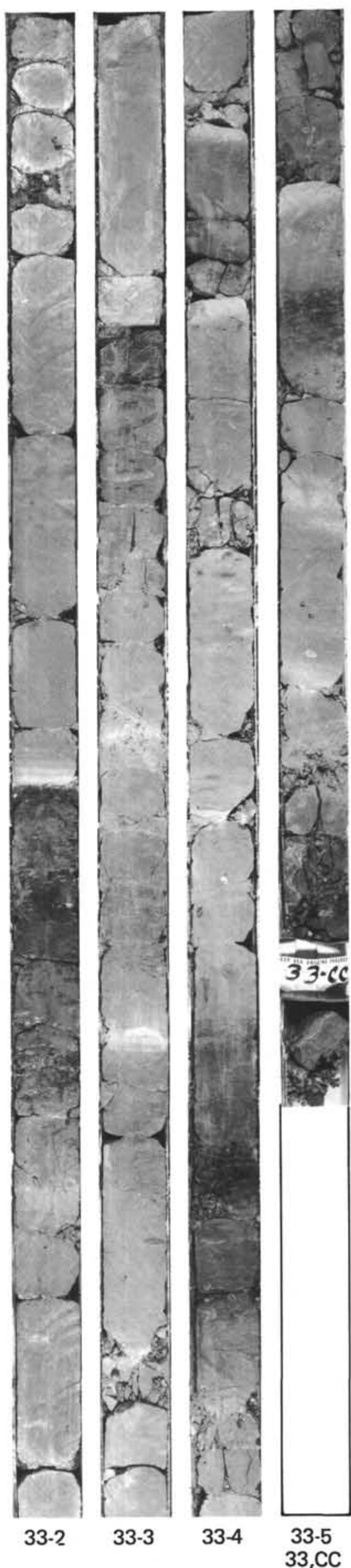


Site 445

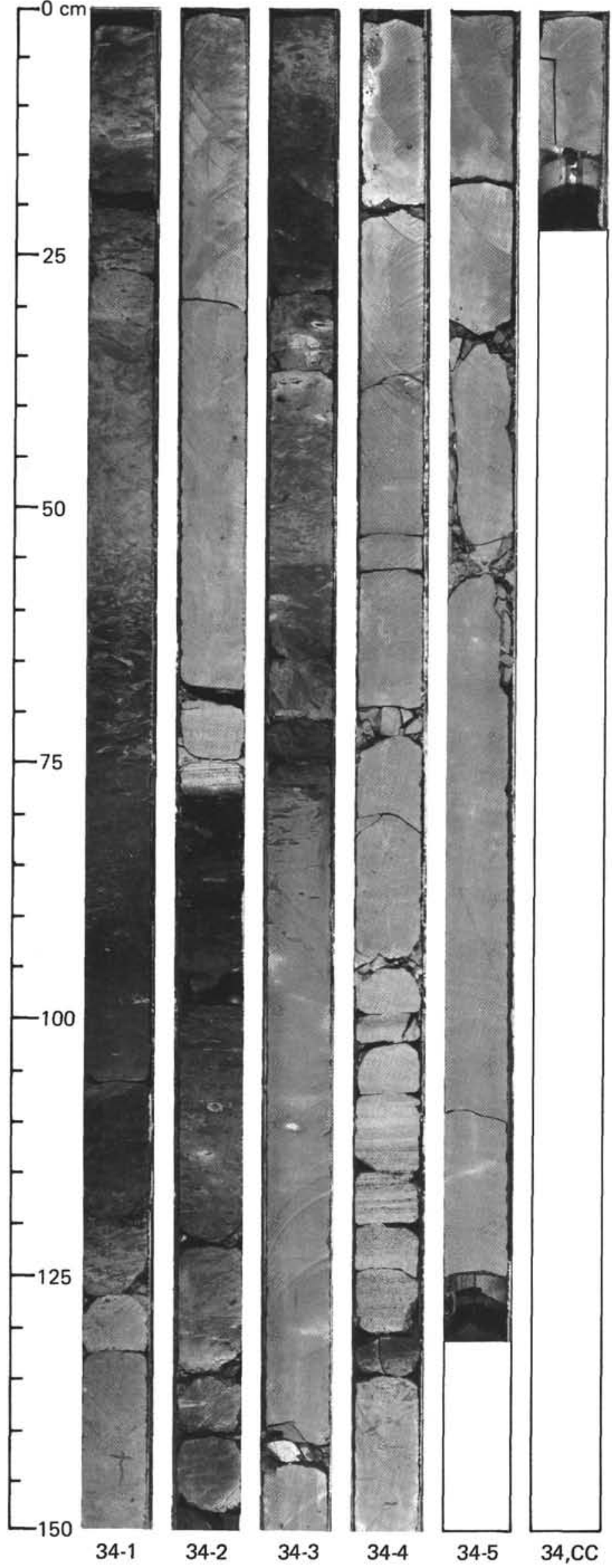

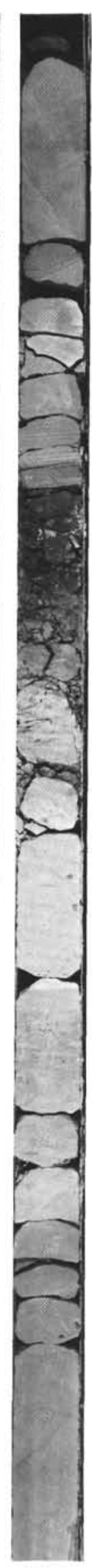

35-1

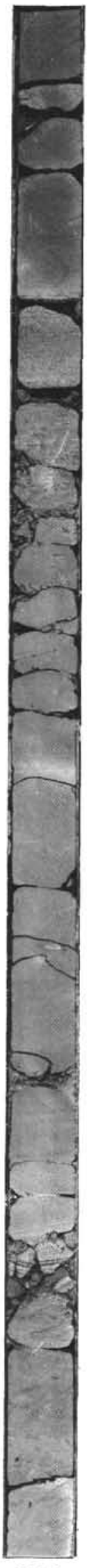

$35-2$
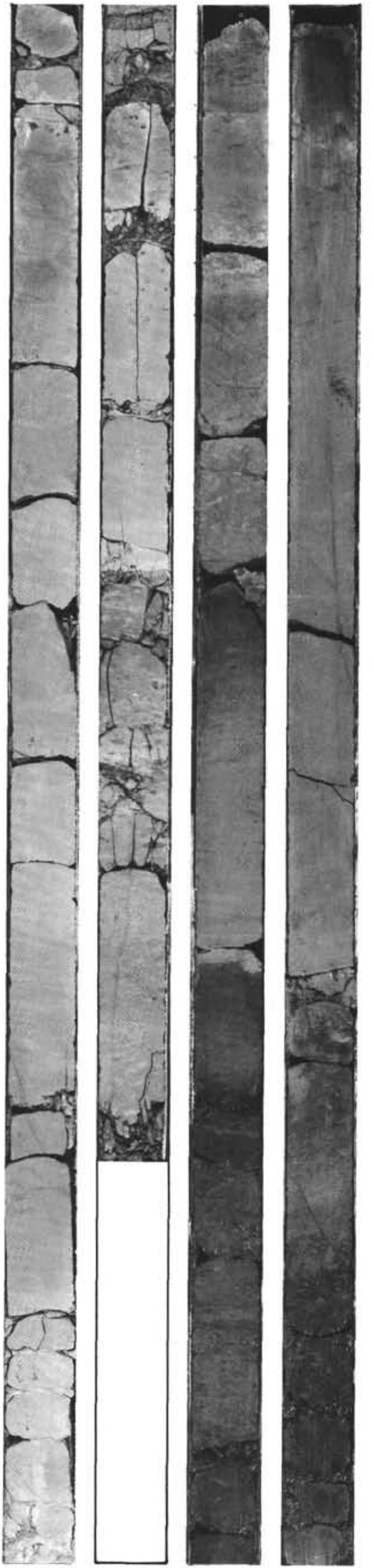

36-2 
Site 445

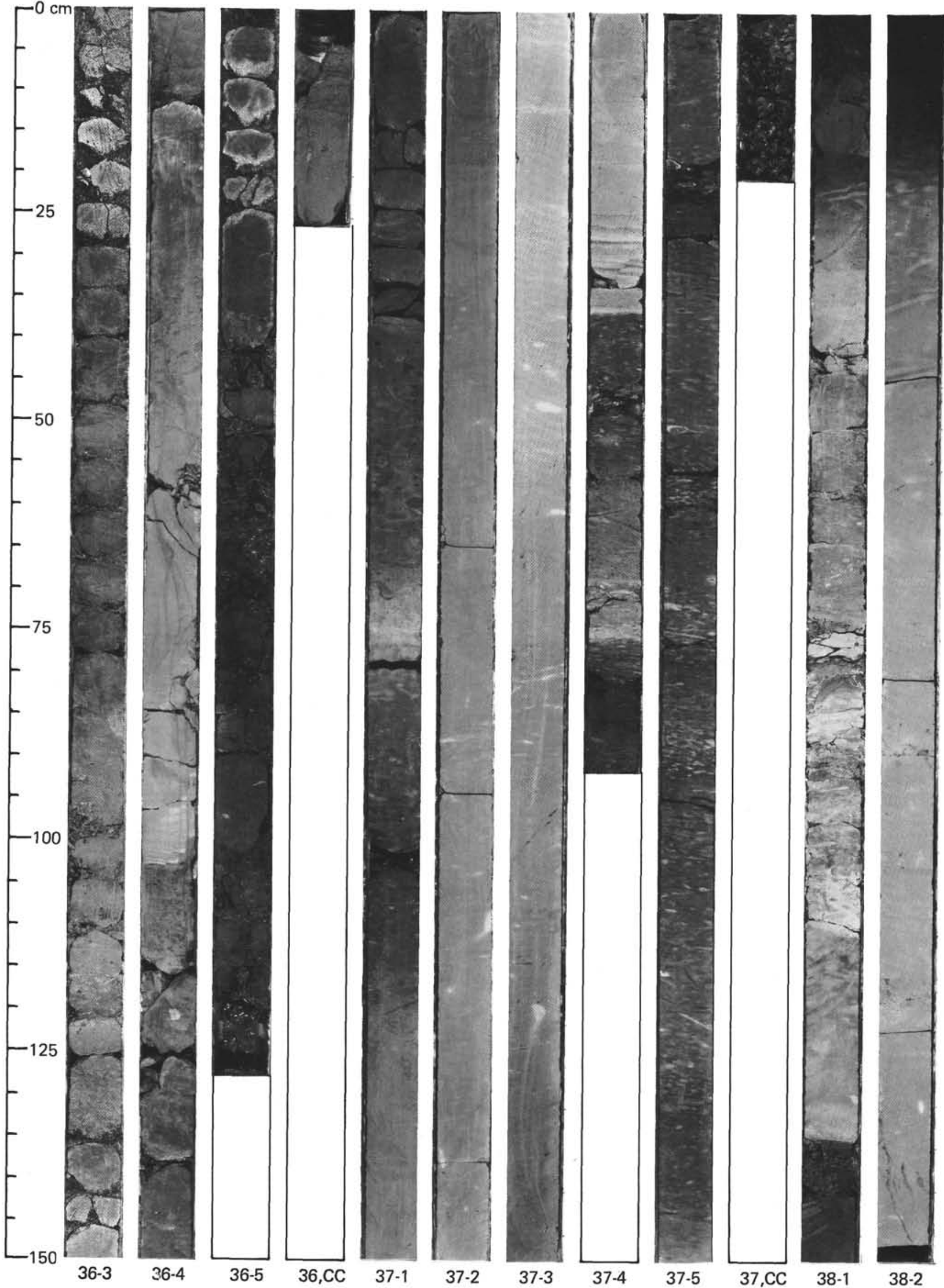




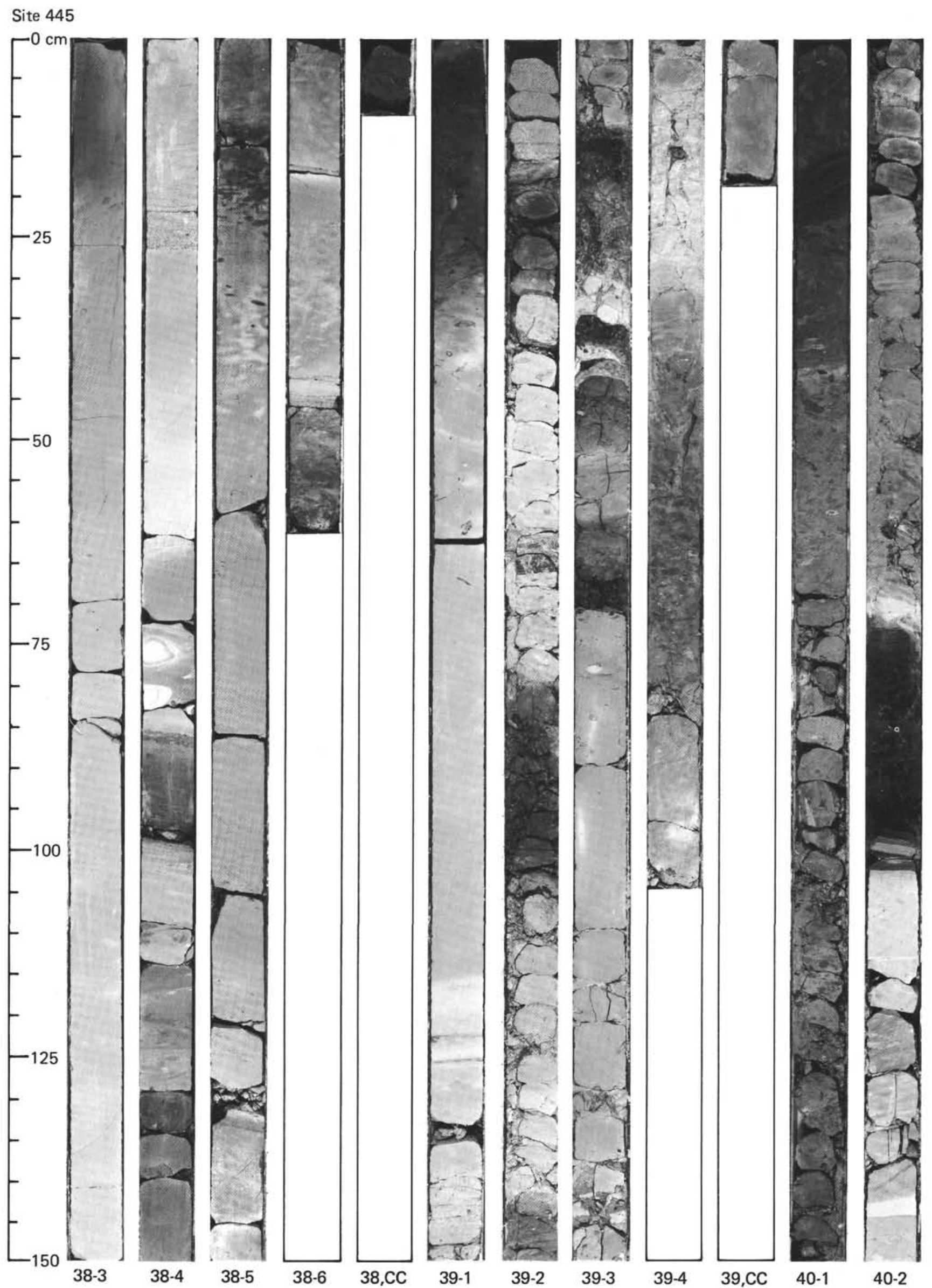


Site 445

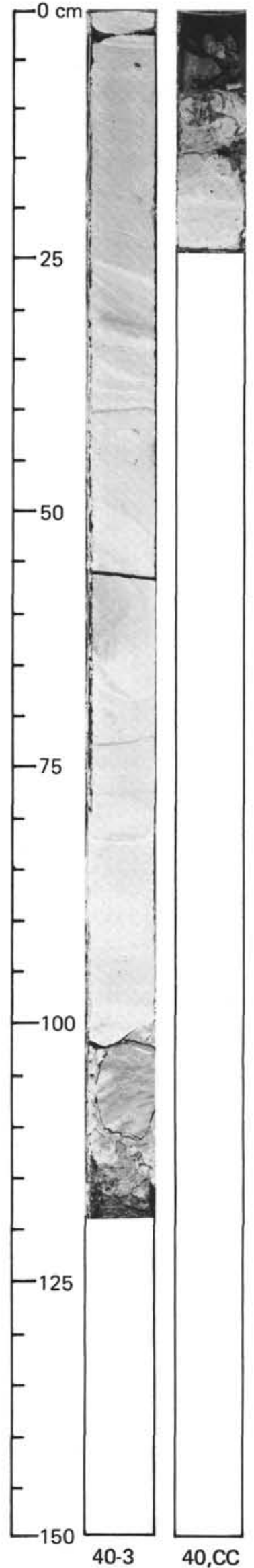

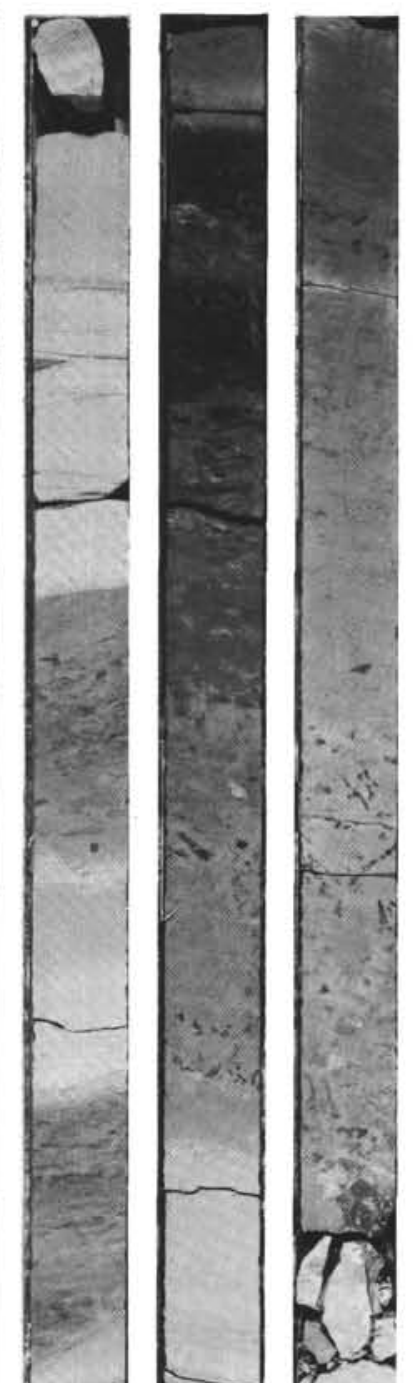
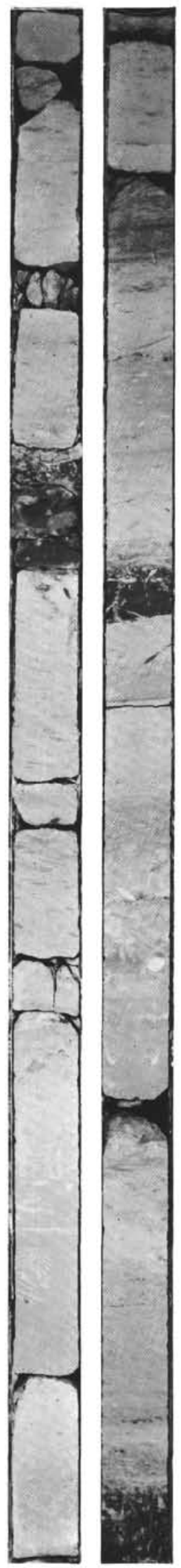

41-4
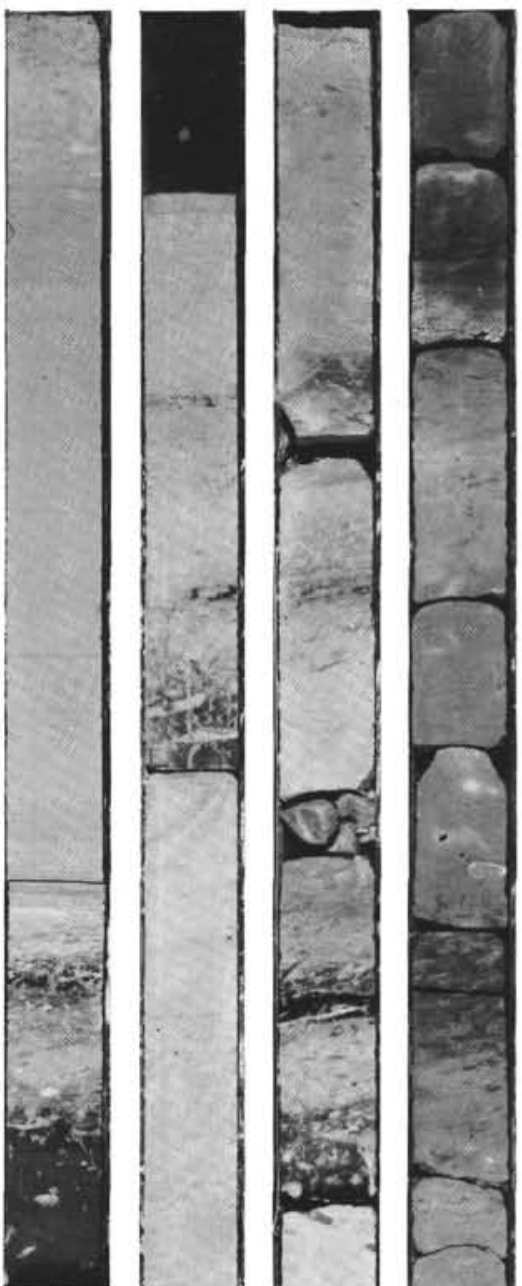

Ey

p
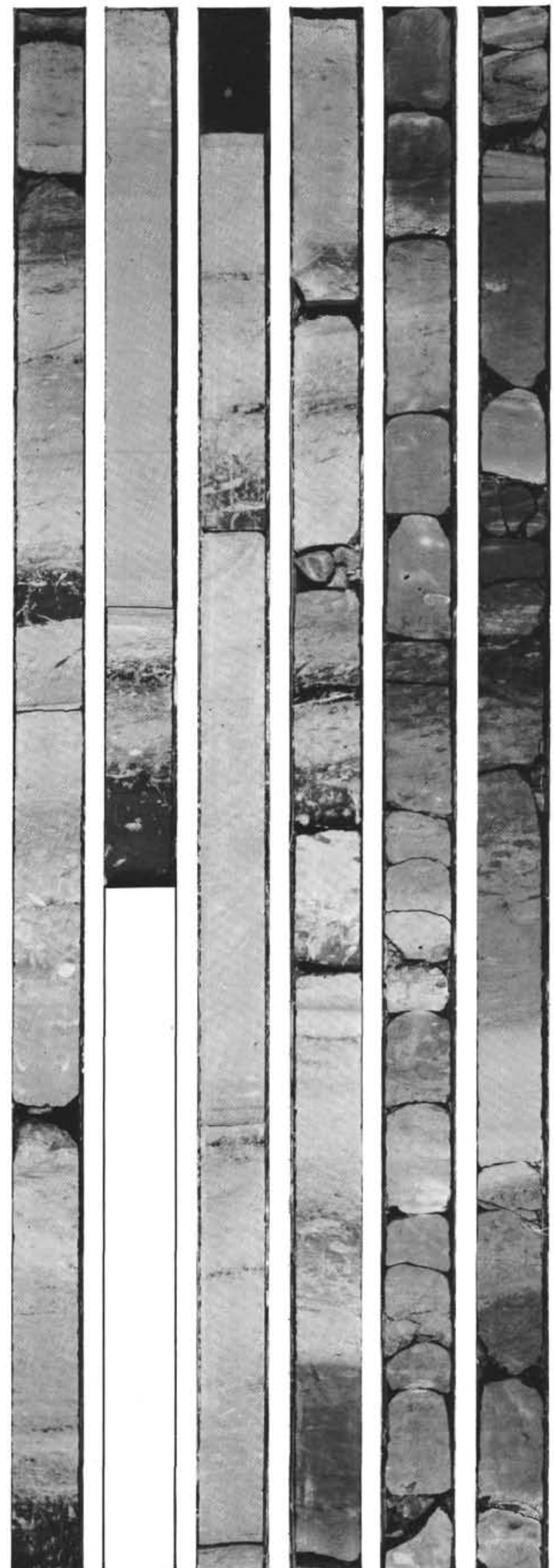

42-1
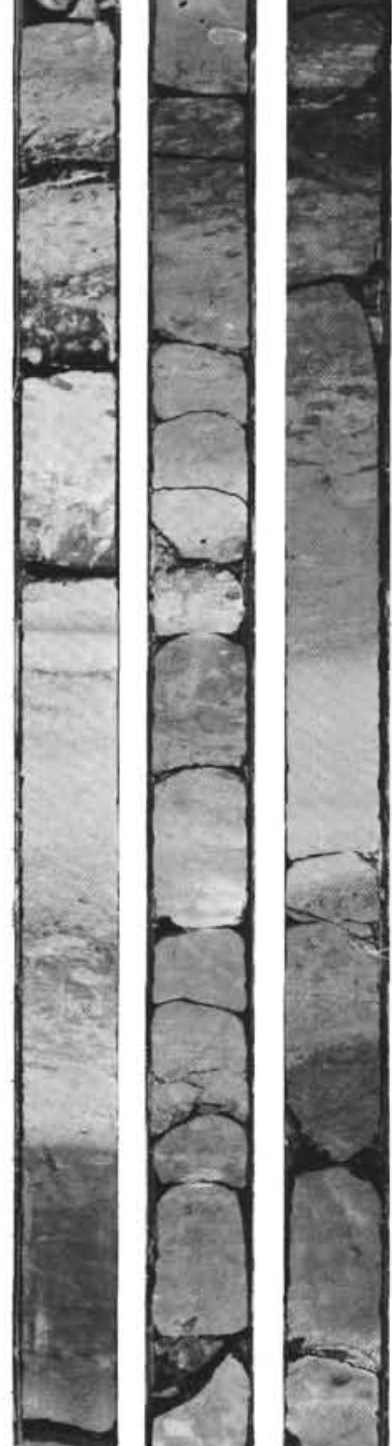

$41-5$

41-6

$42-2$

$42-3 \quad 42-4$ 
SITE 445

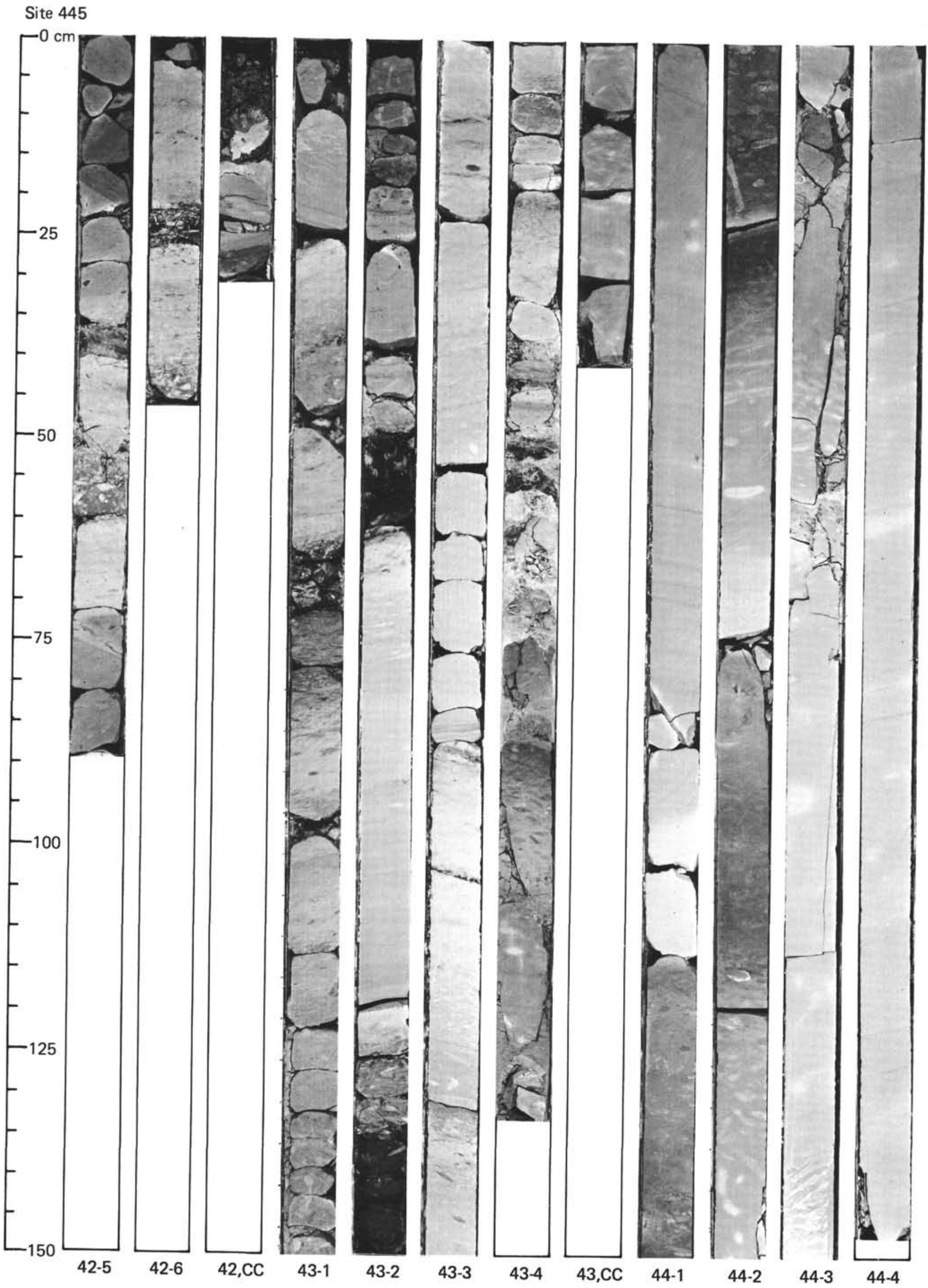


Site 445

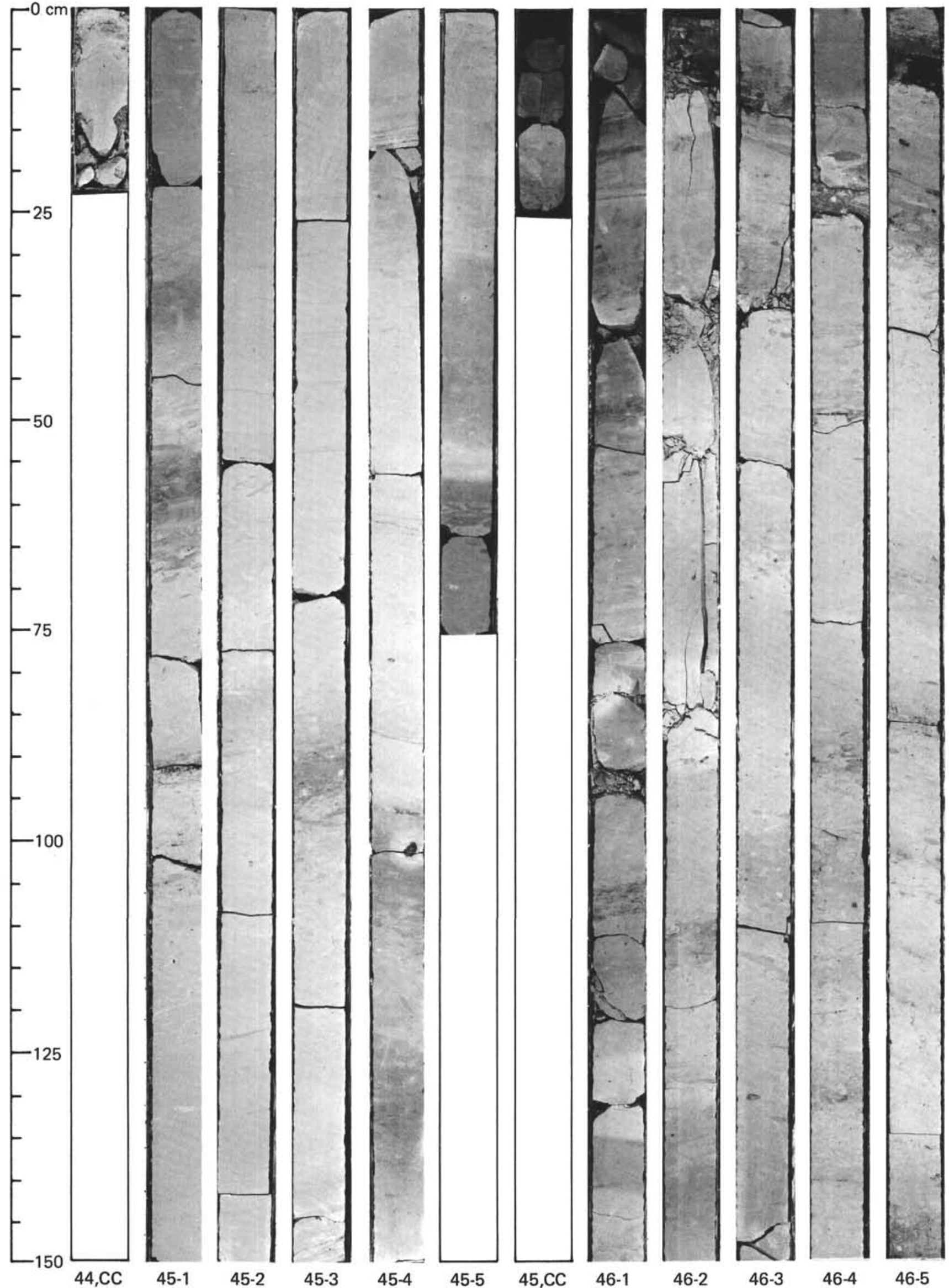


SITE 445

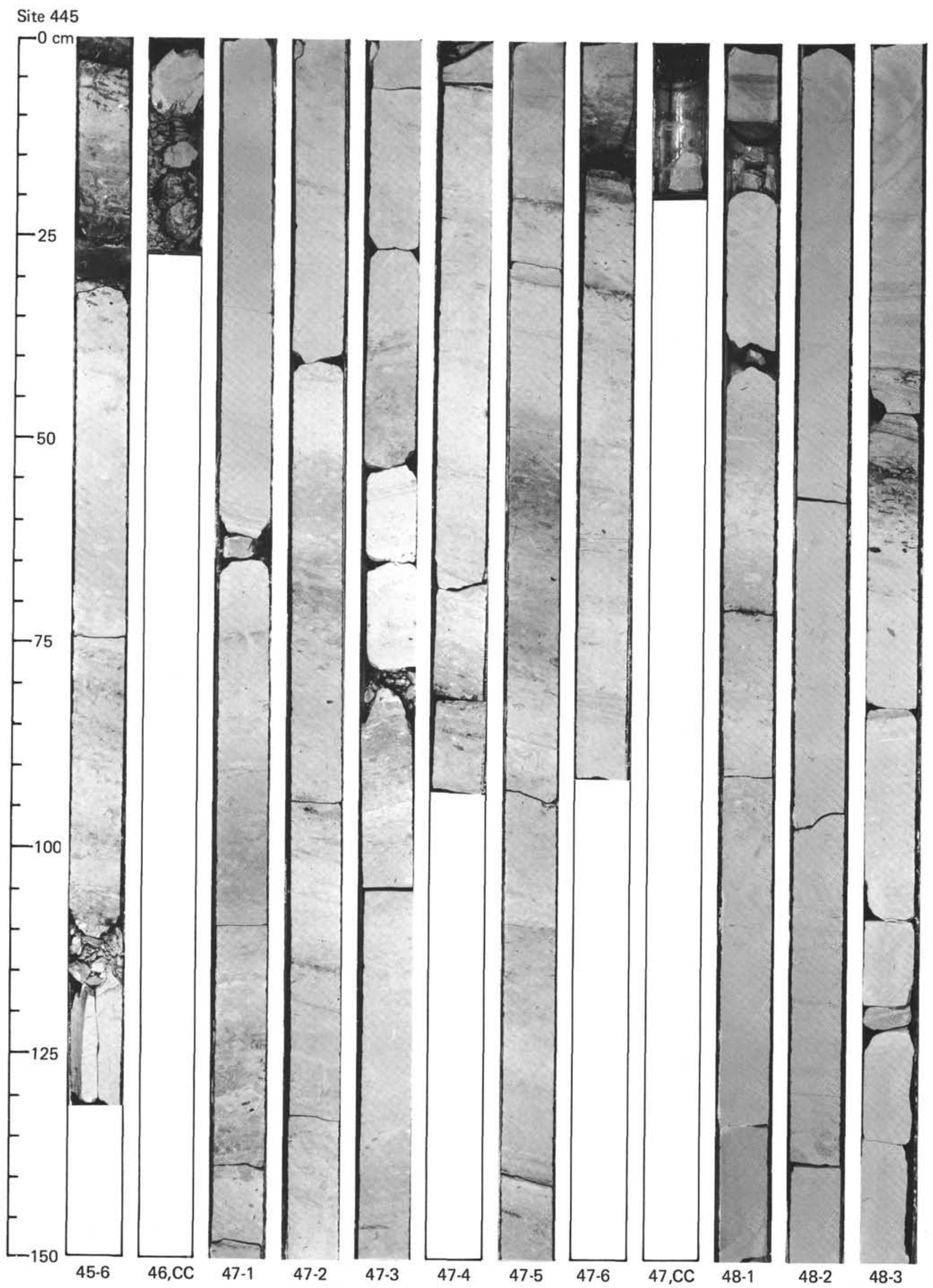


Site 445

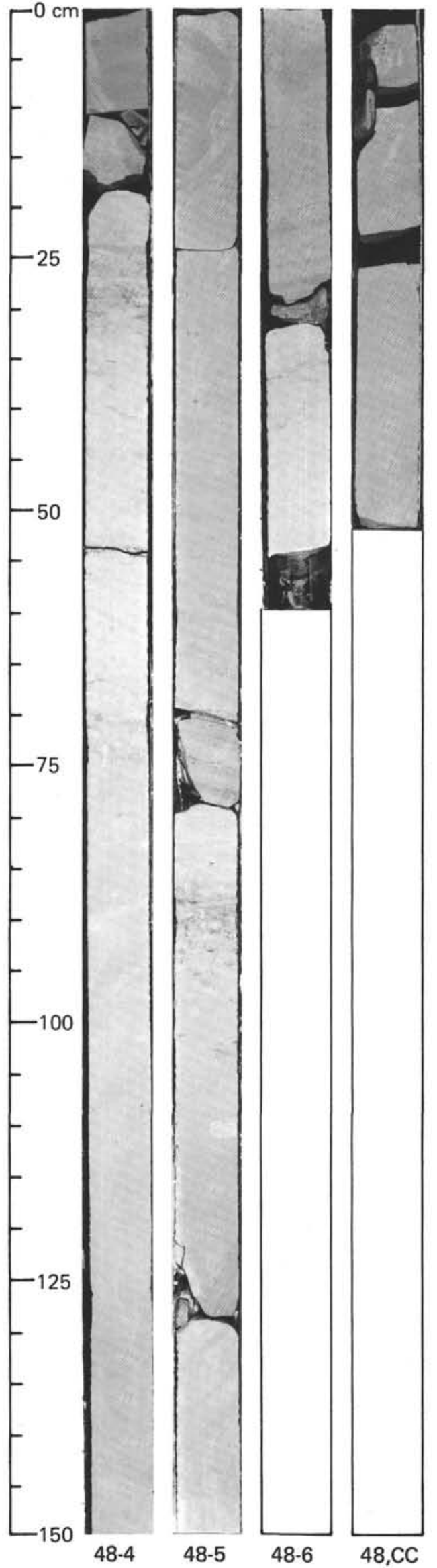

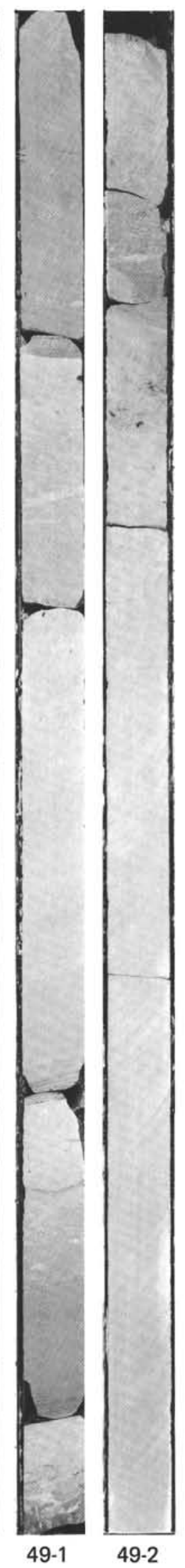

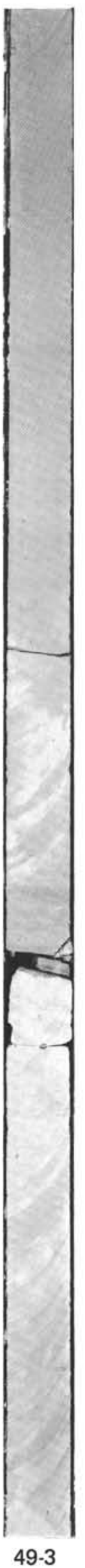

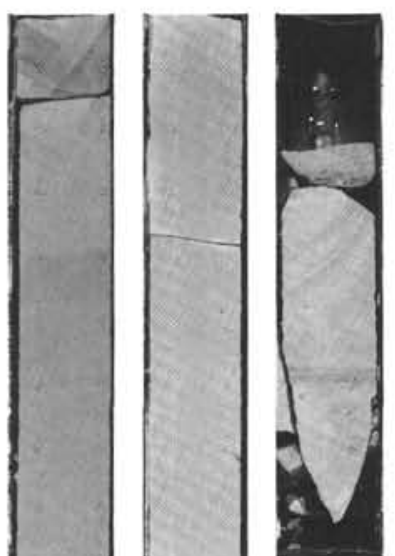
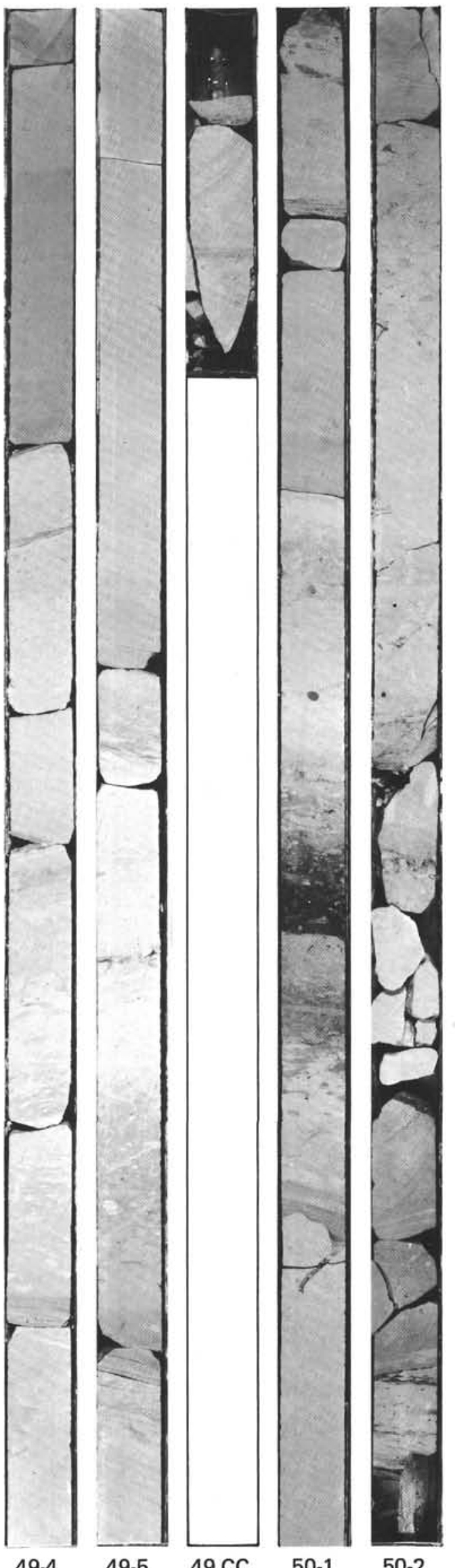
SITE 445

Site 445

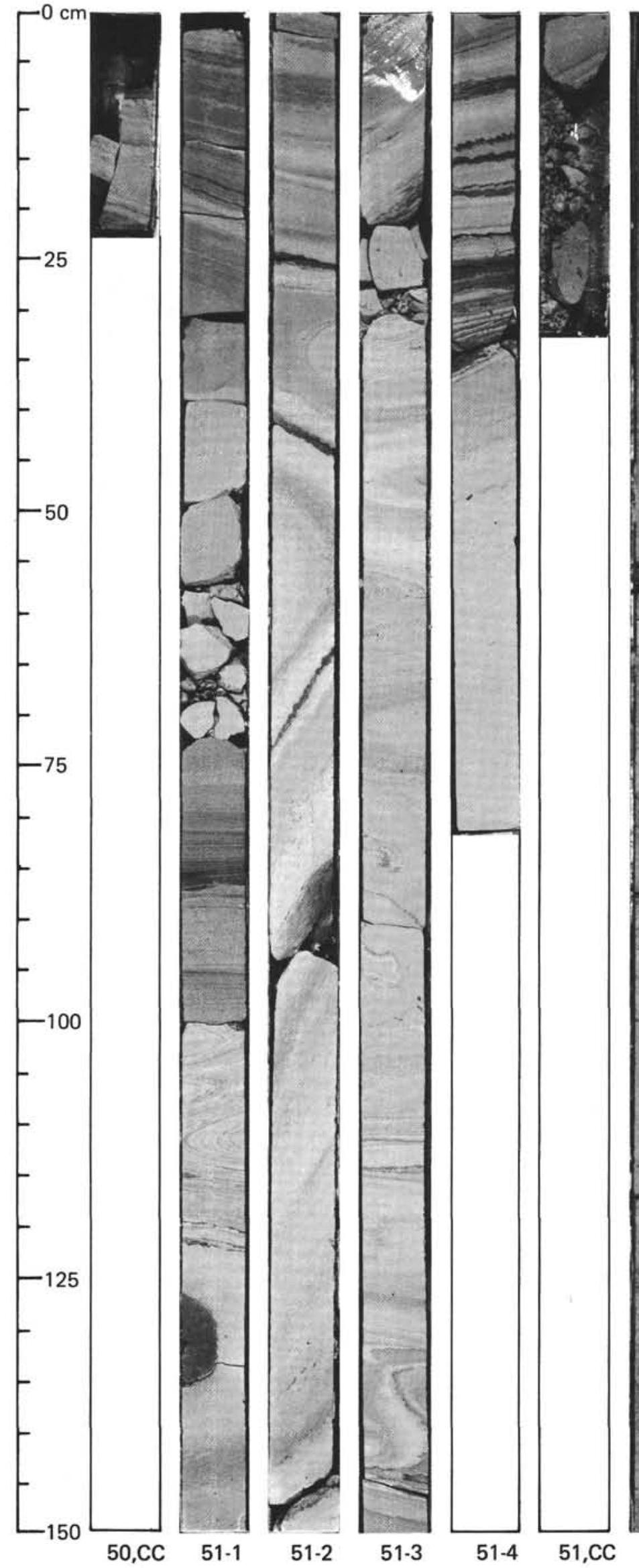

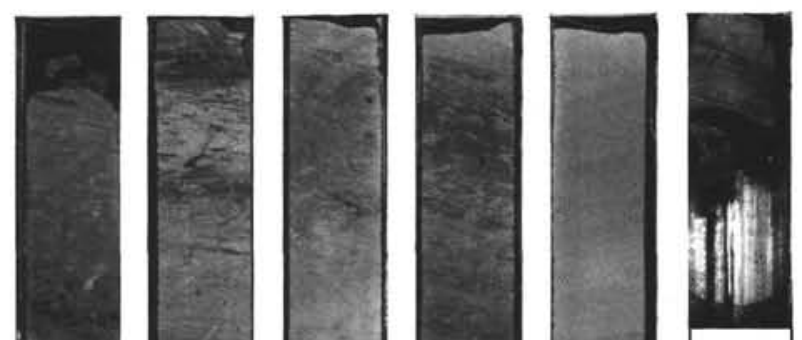
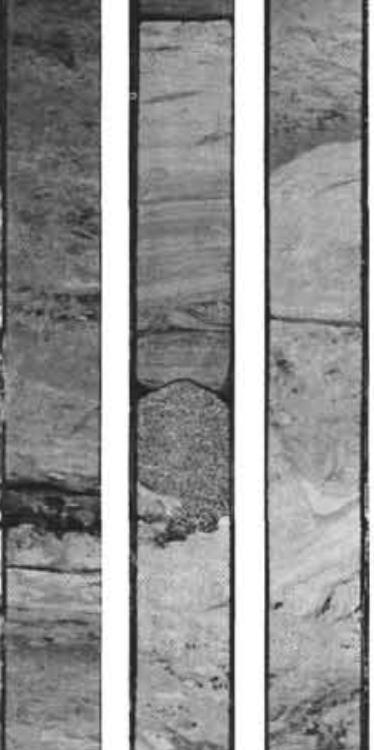

$7=$
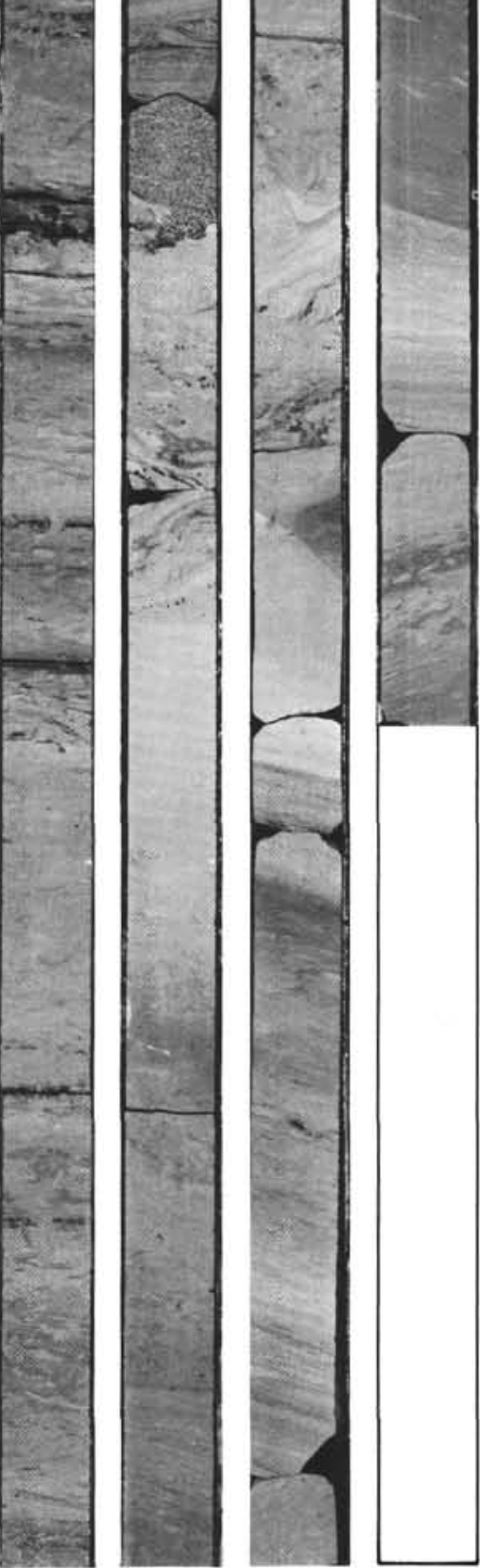

52-1

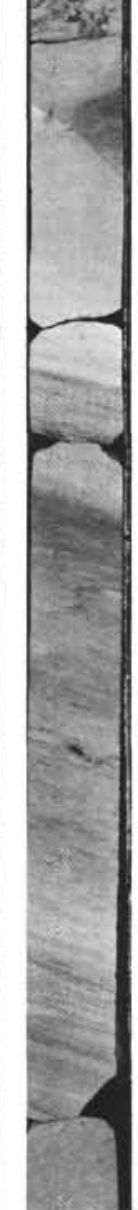

52-3

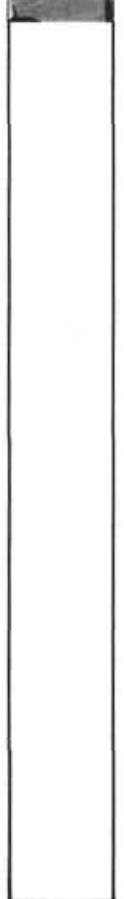

52-4 
Site 445

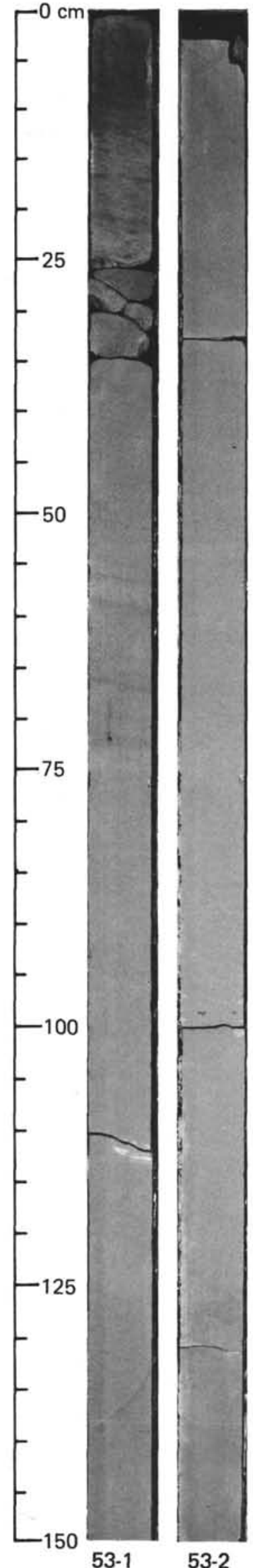

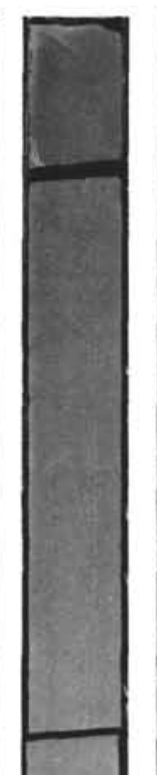
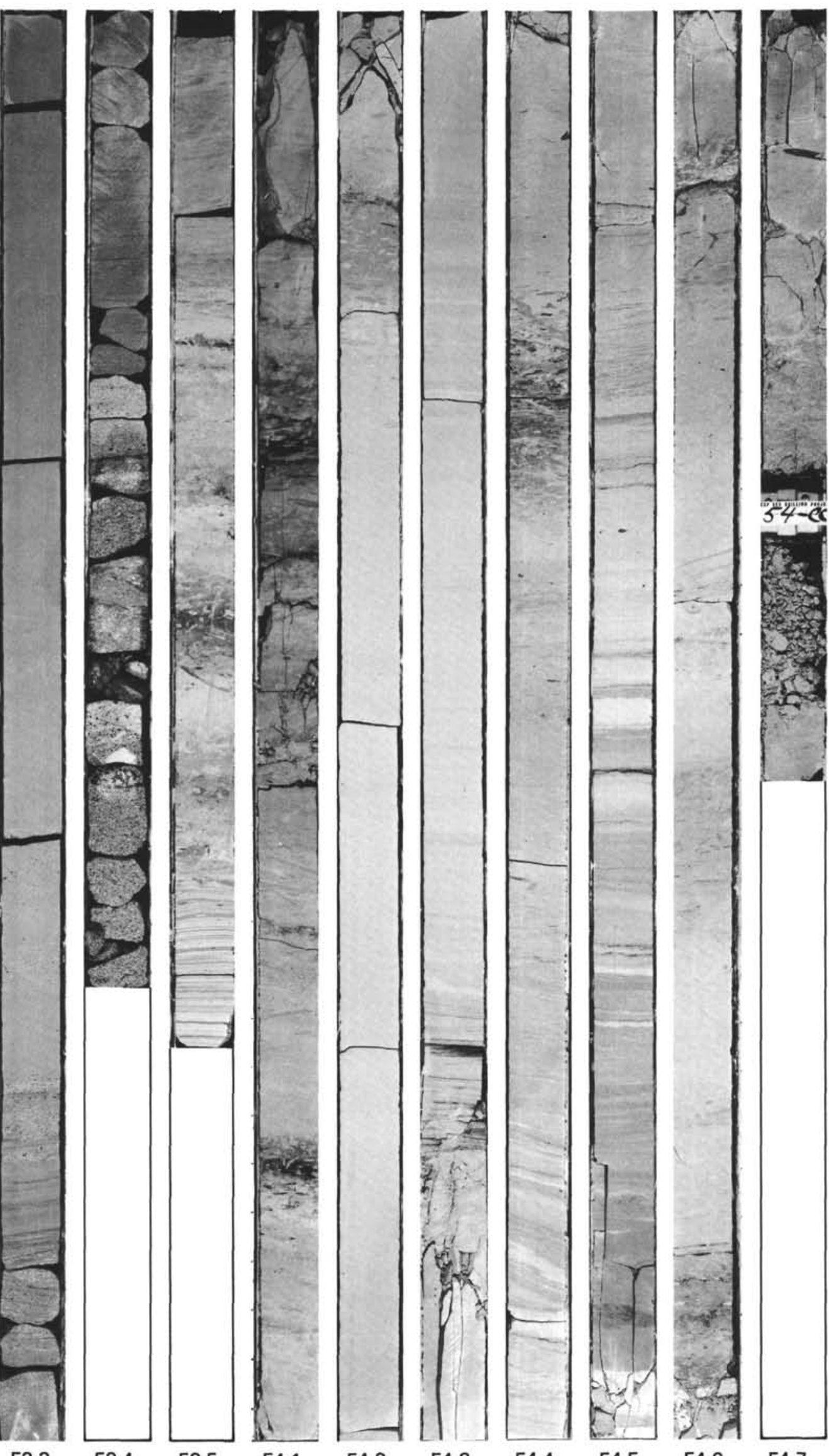
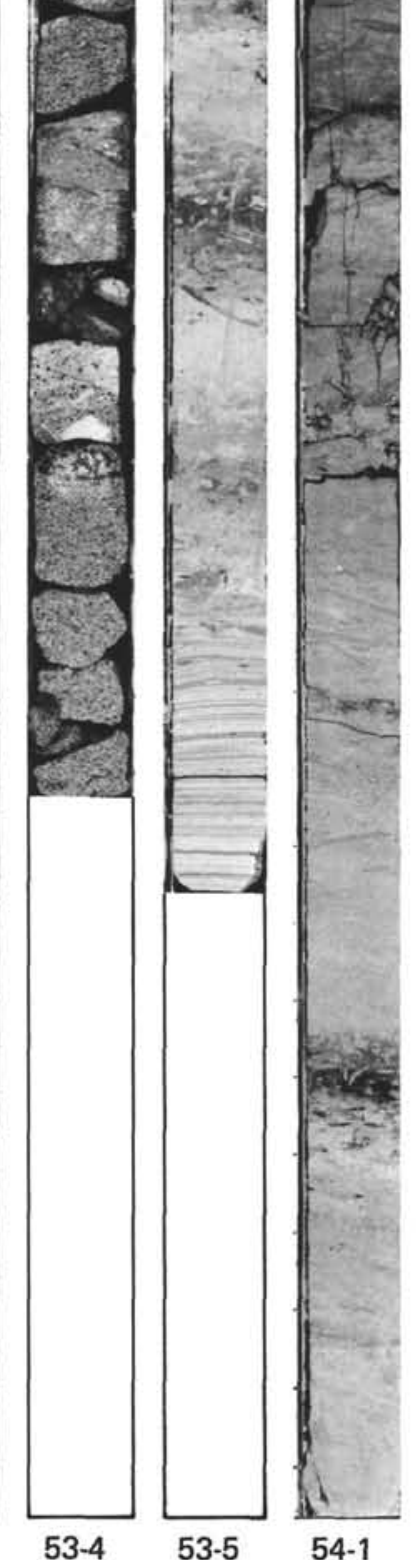

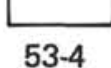

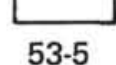

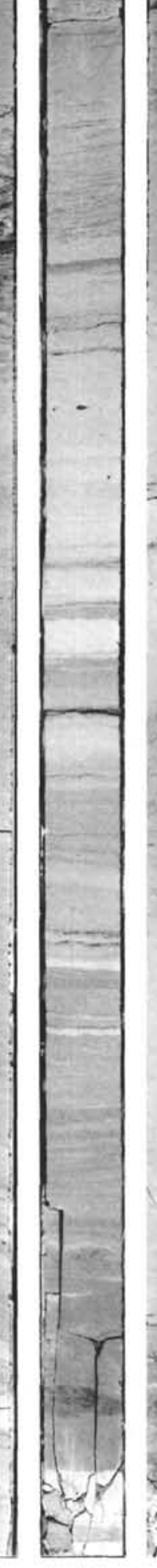

54-5

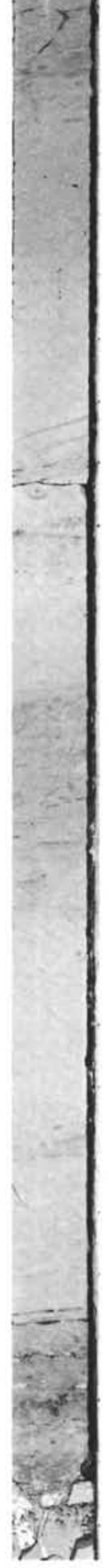

54-6

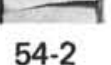

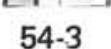

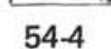




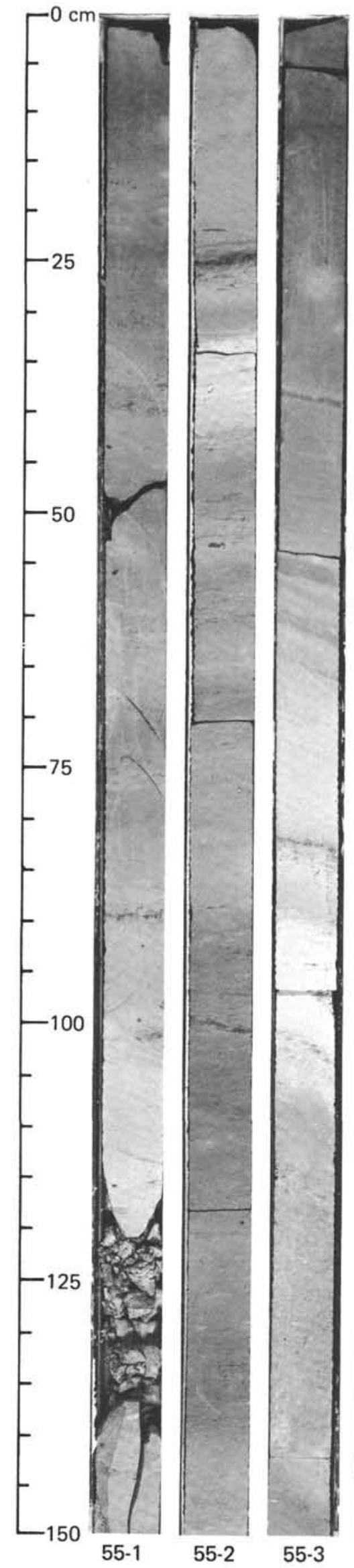

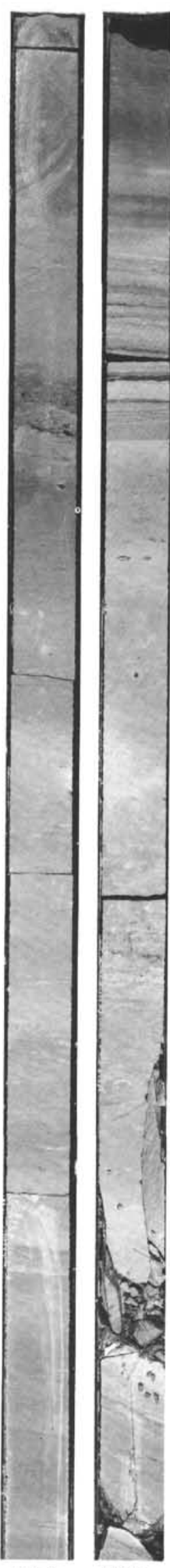

$55-4$
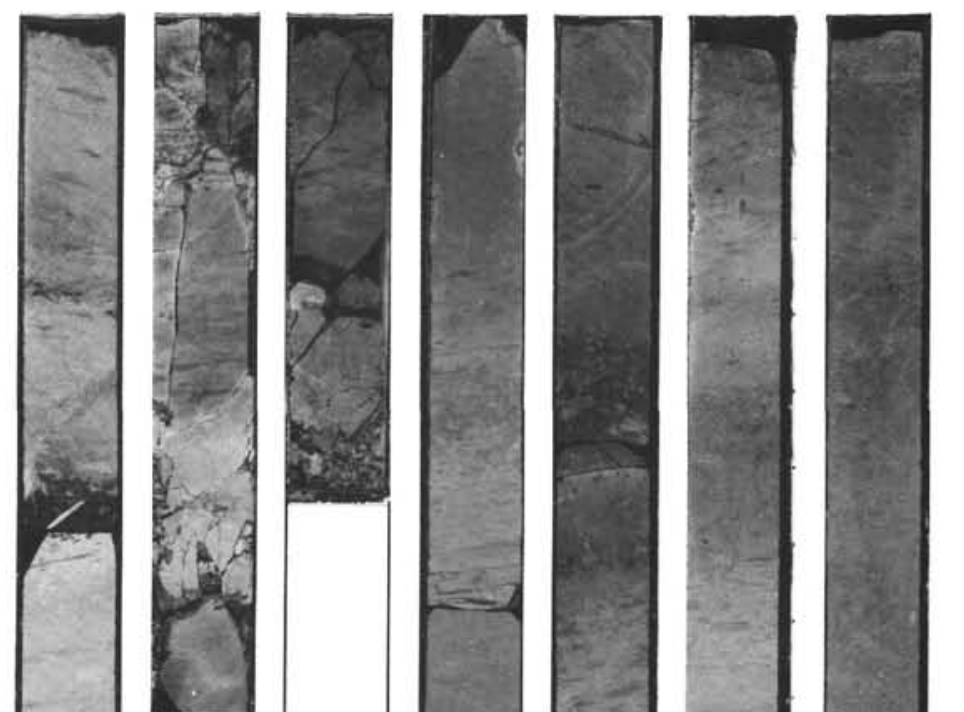

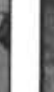
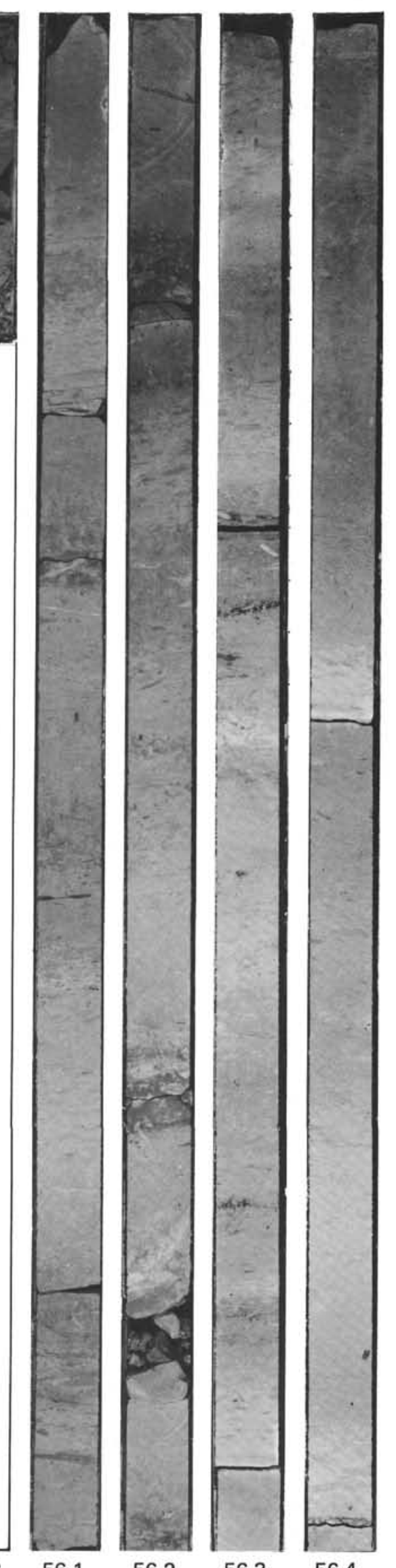
Site 445

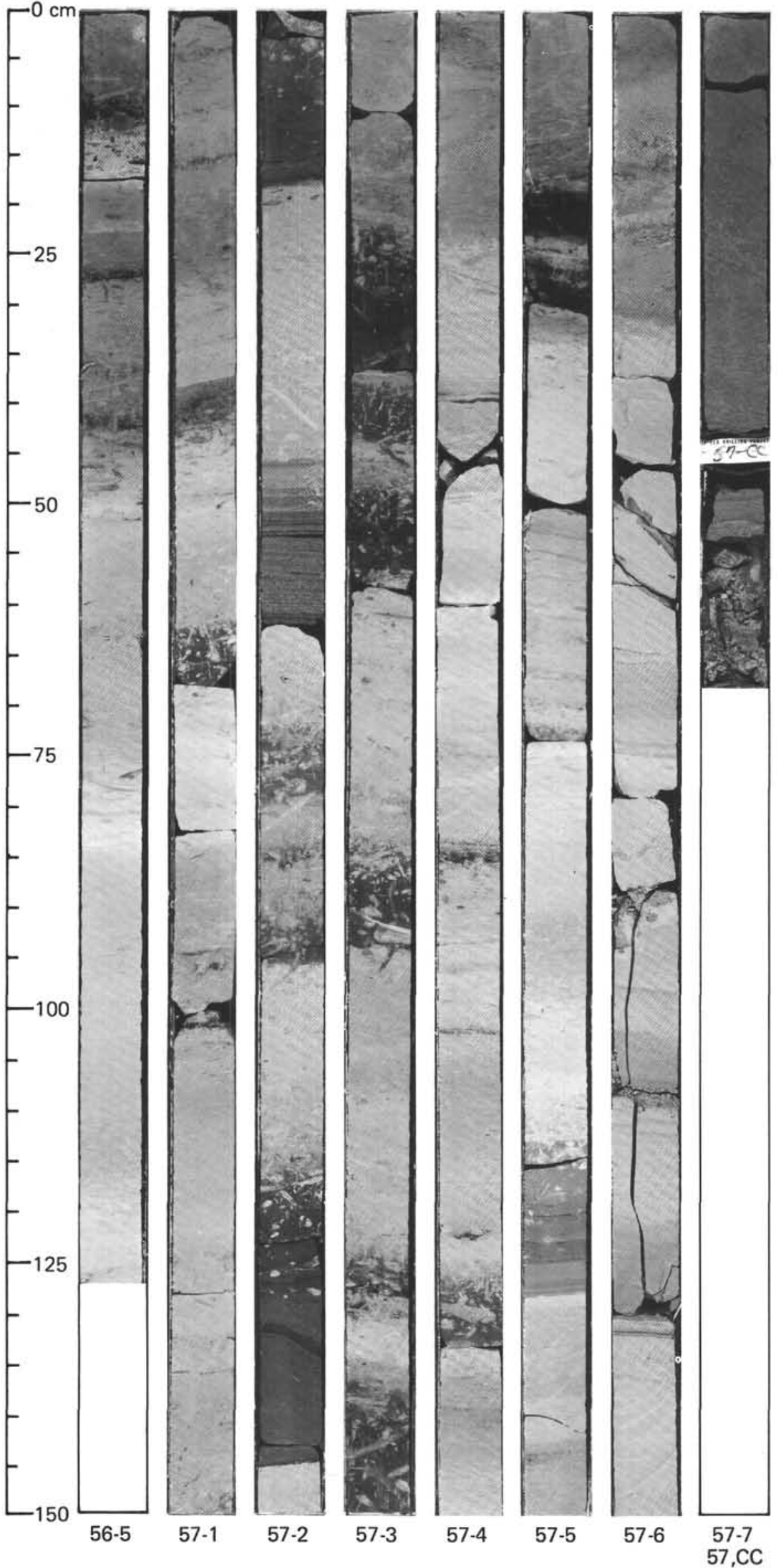

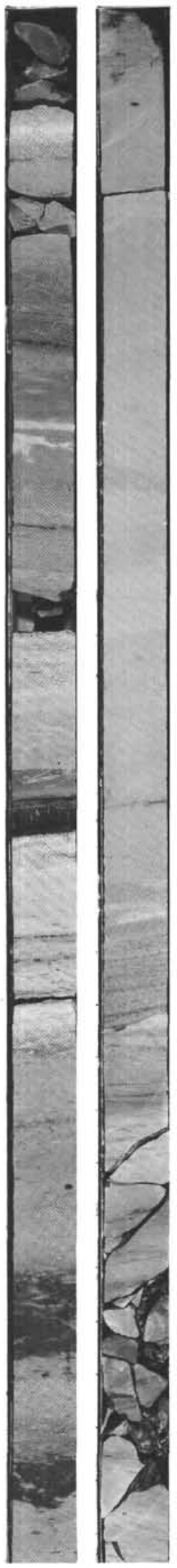

58-1
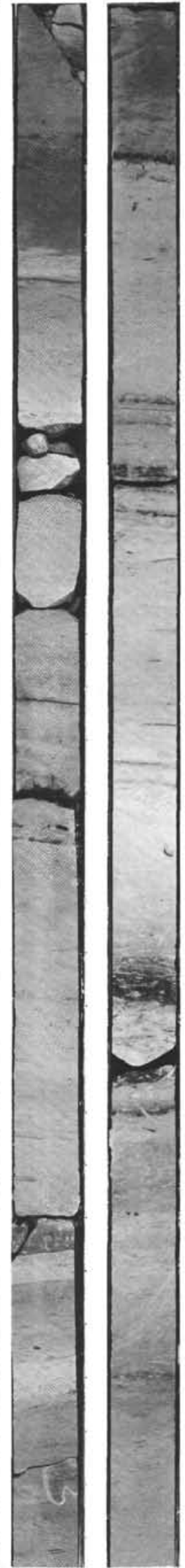

58-2 58-3 58-4 
SITE 445

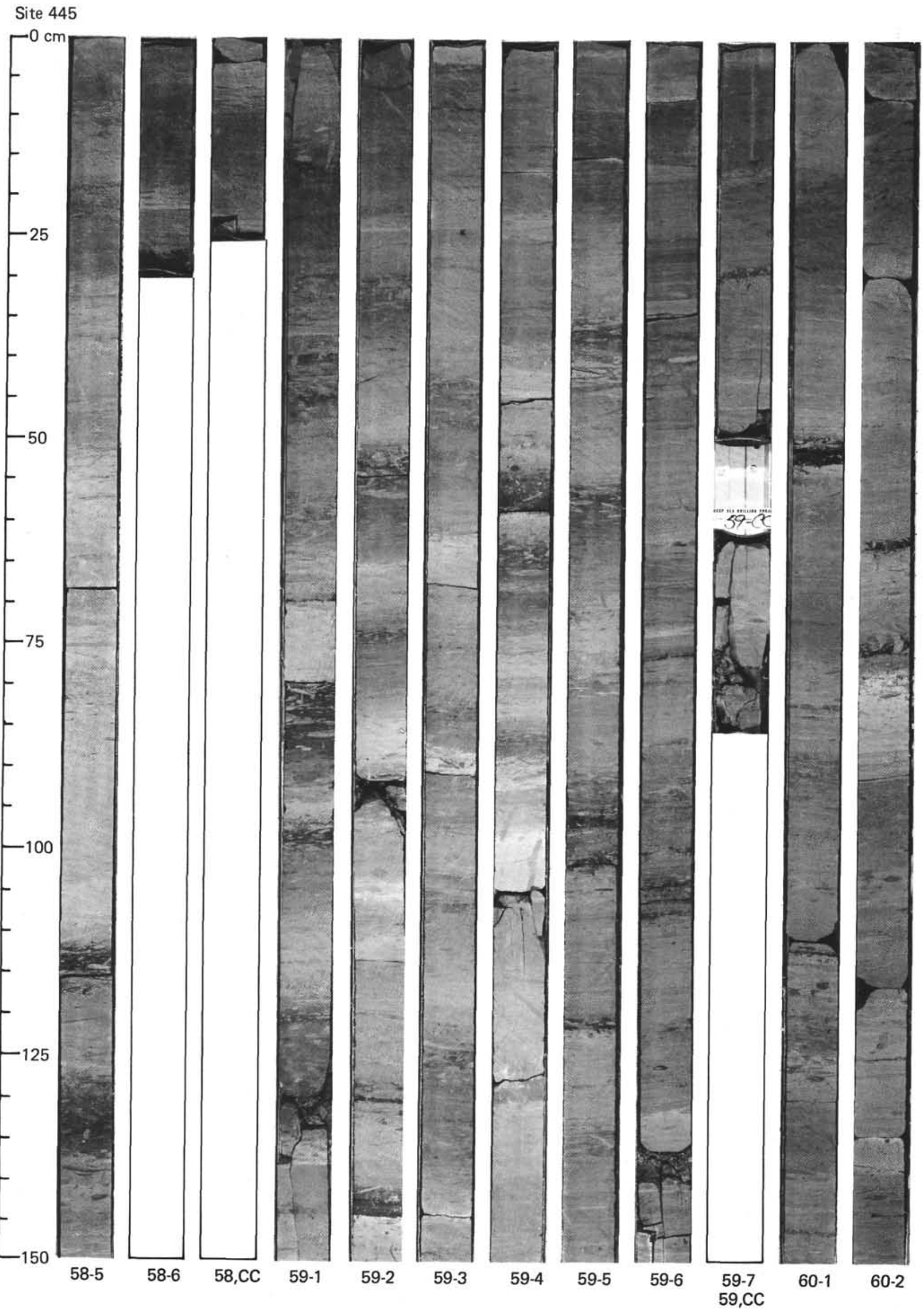


Site 445

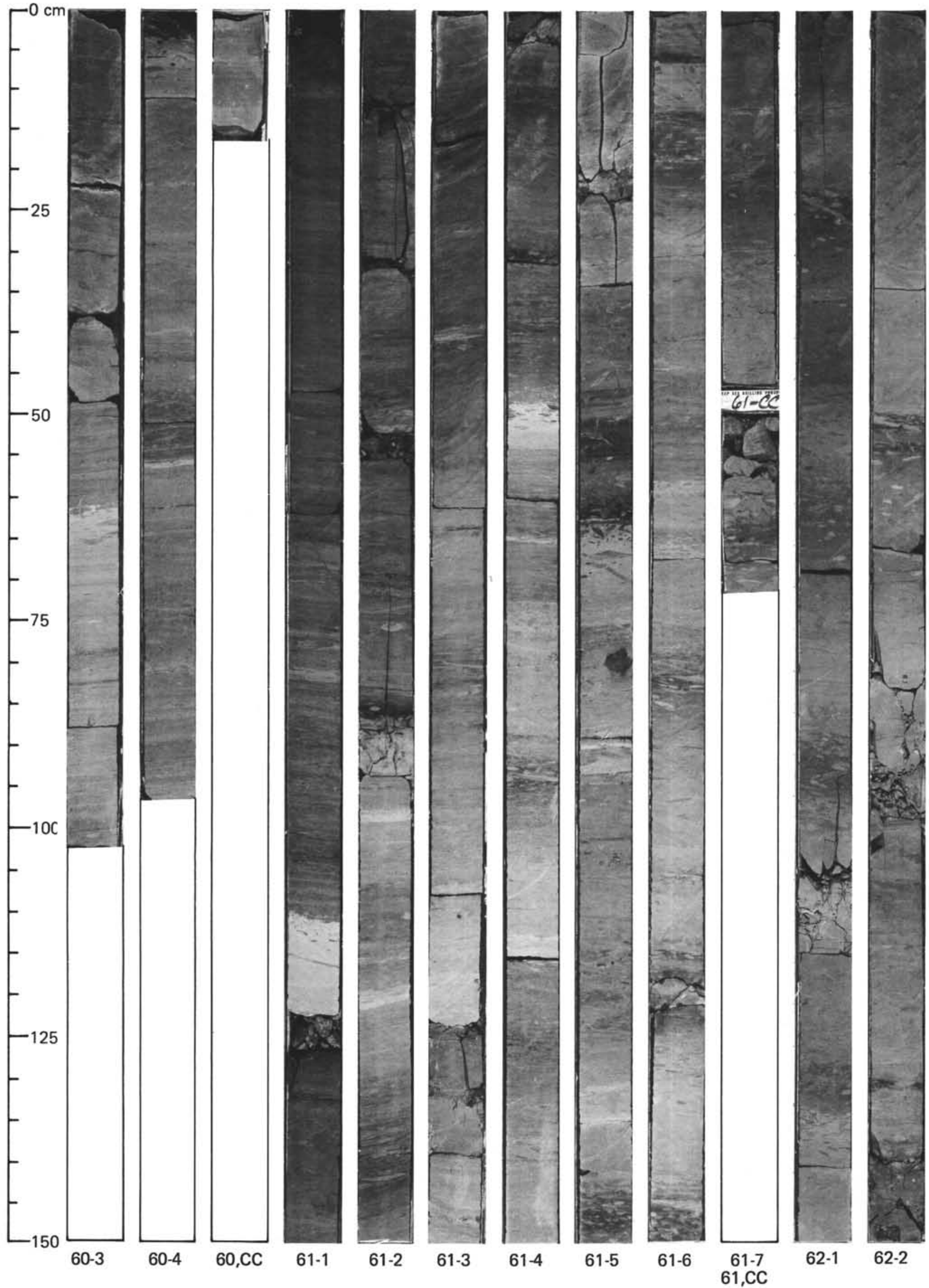




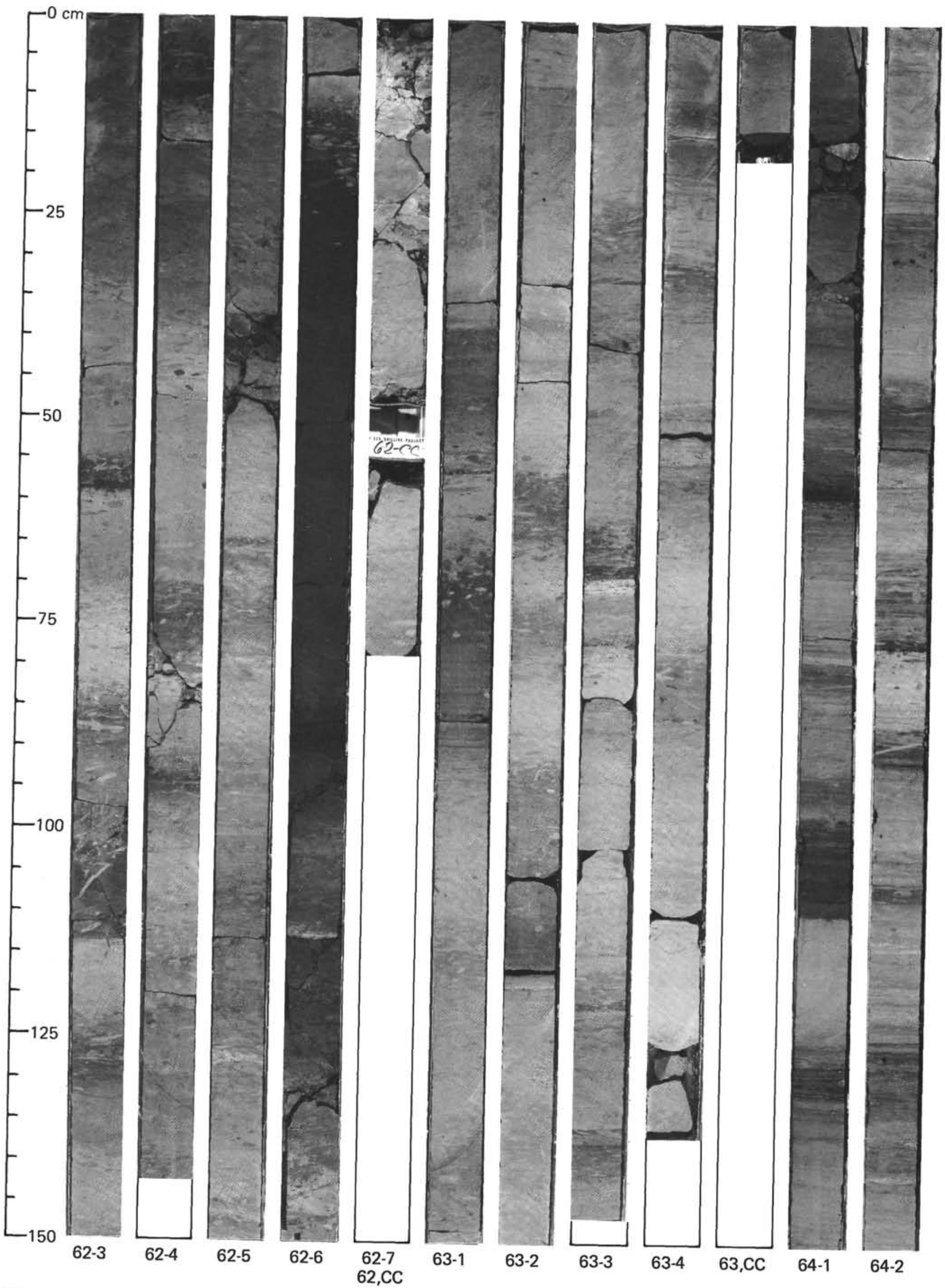


Site 445

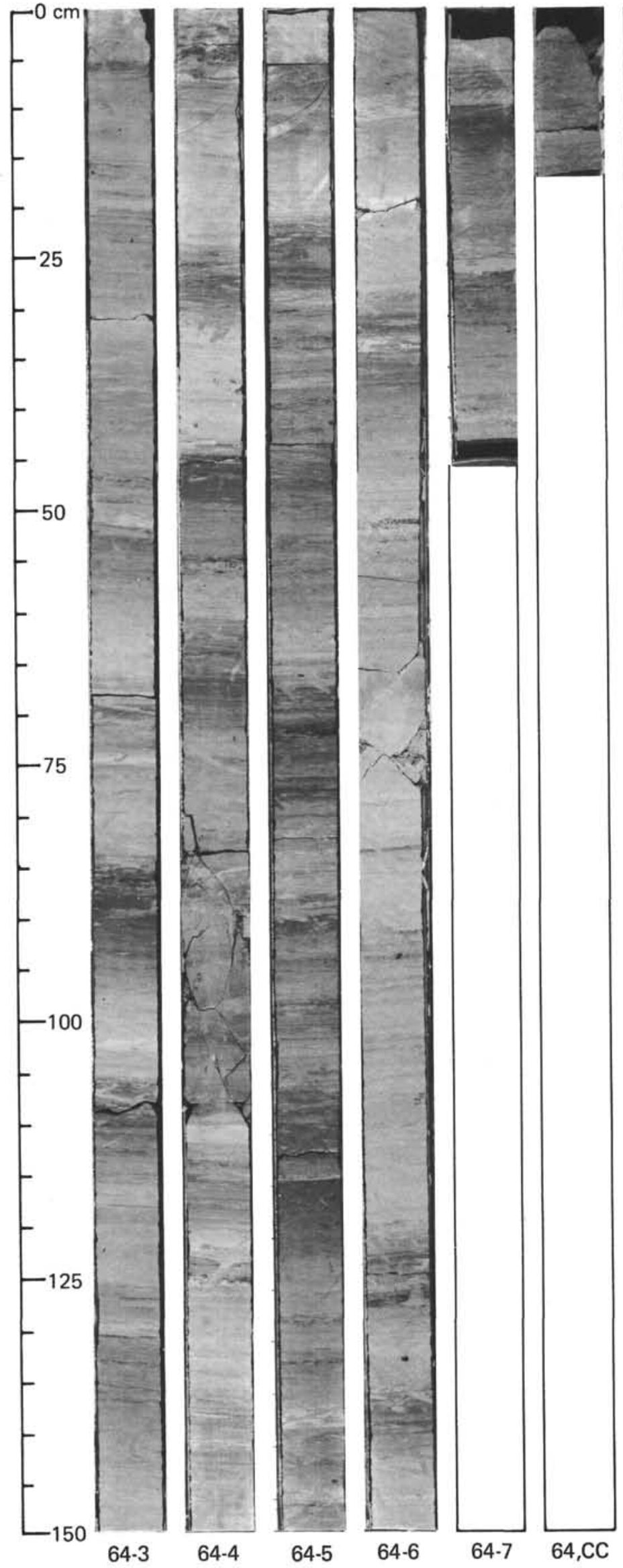

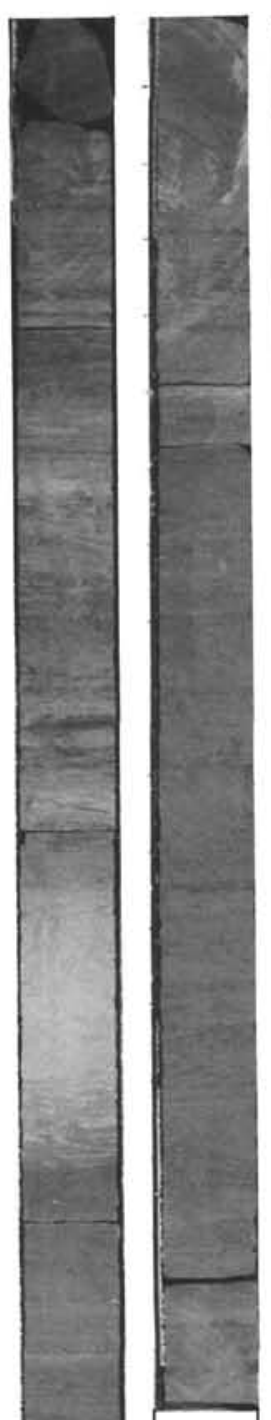
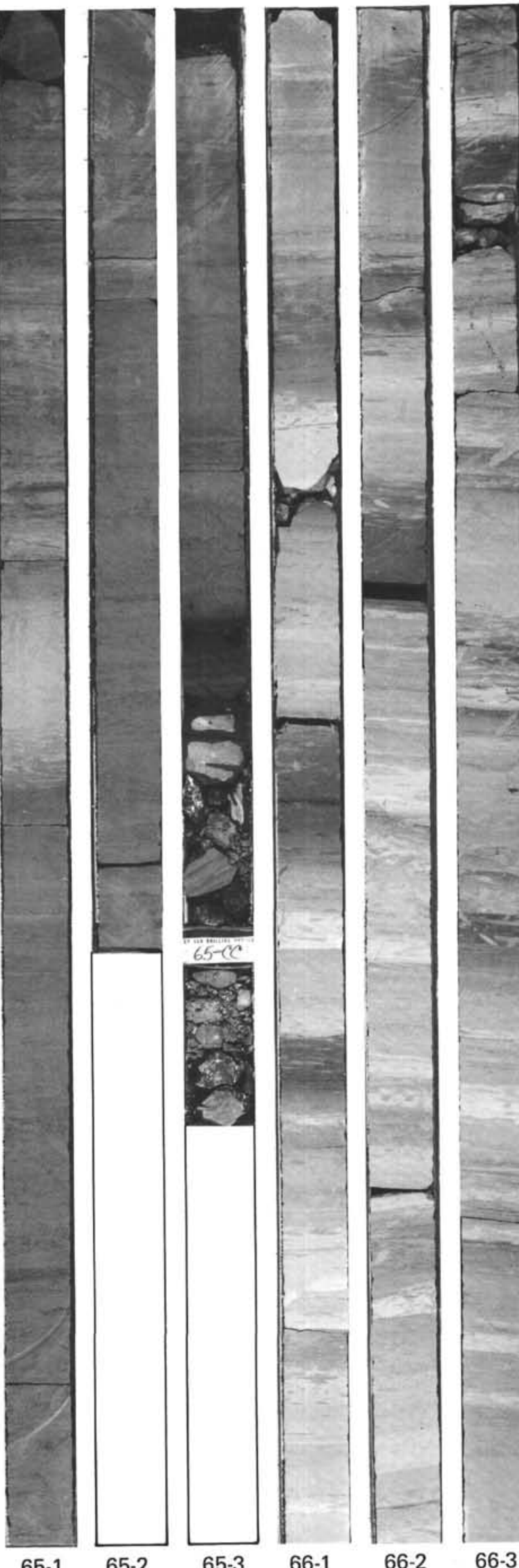

66-2

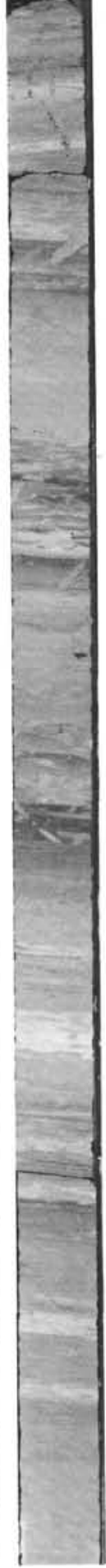

66-3

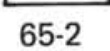



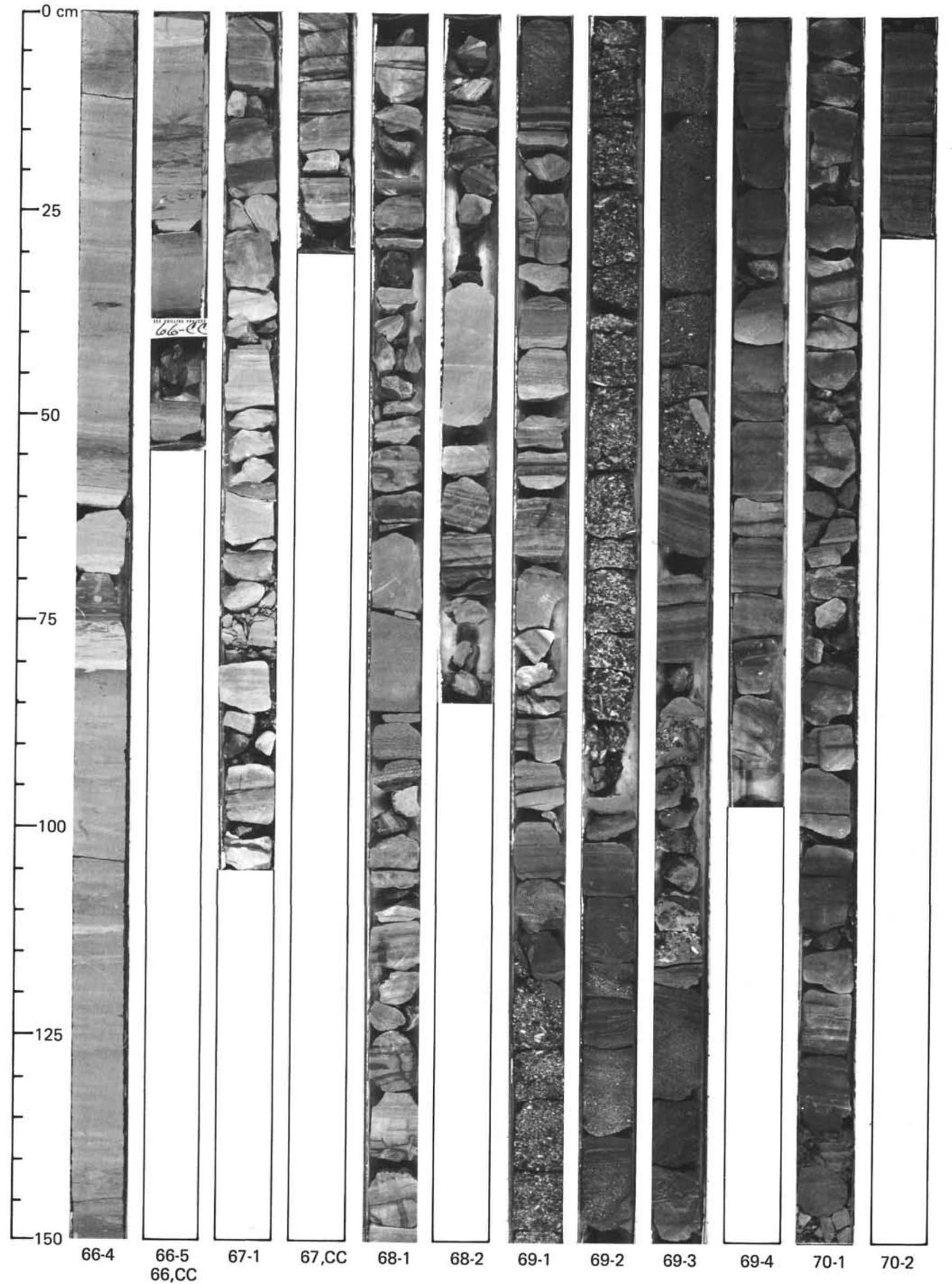

69-1
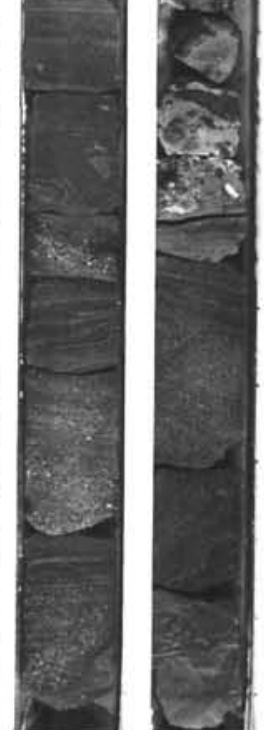

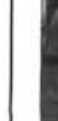

(1)
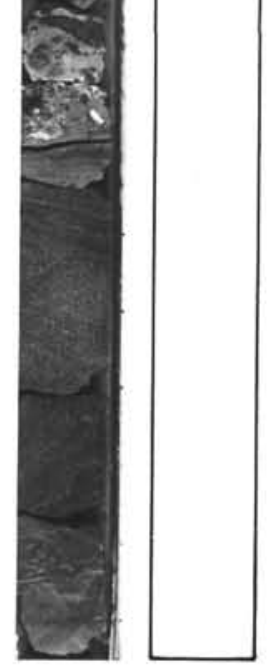

69-2

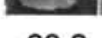

69-4

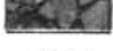

$70-1$ 
Site 445

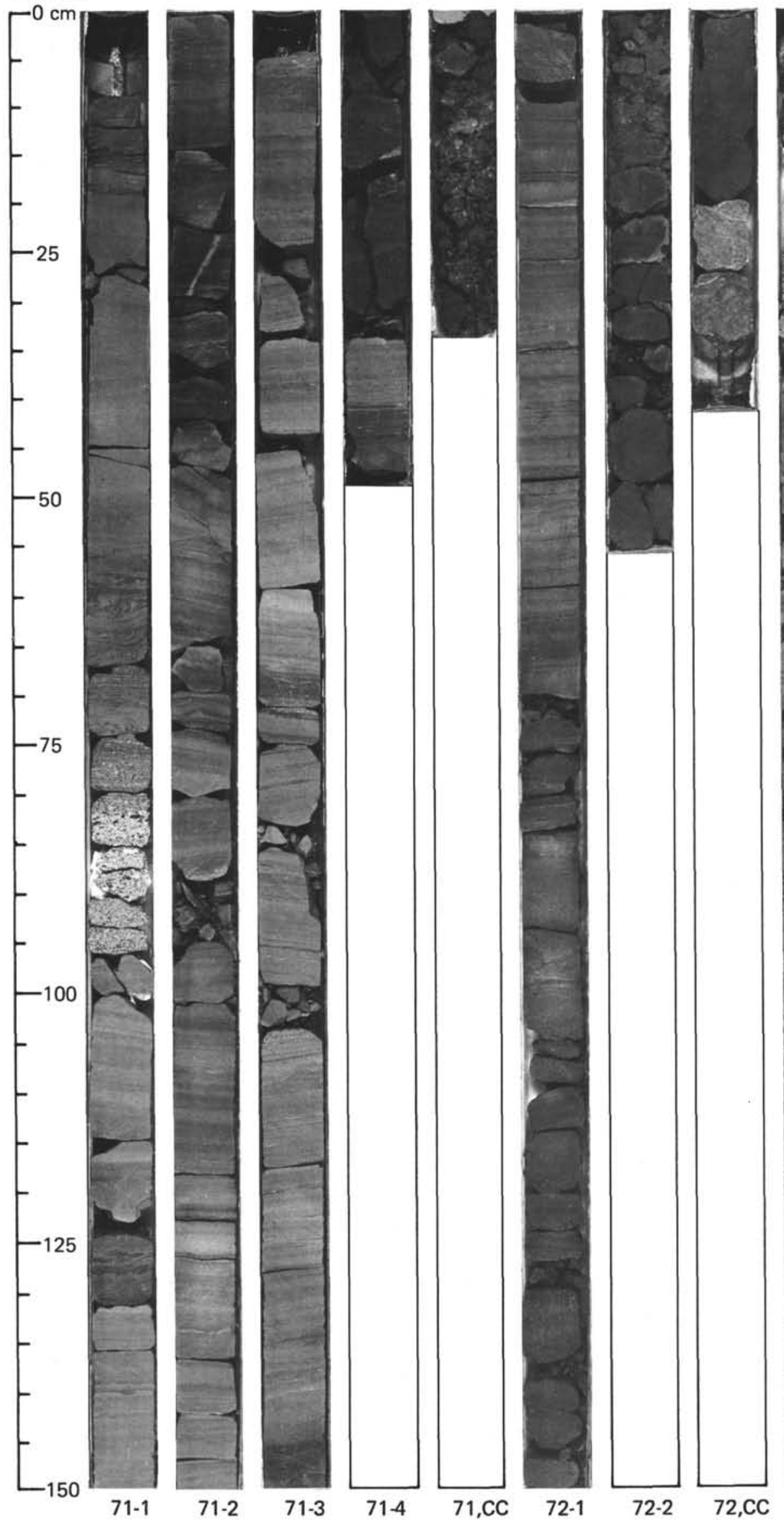

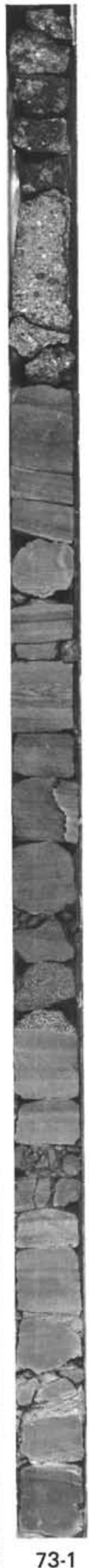

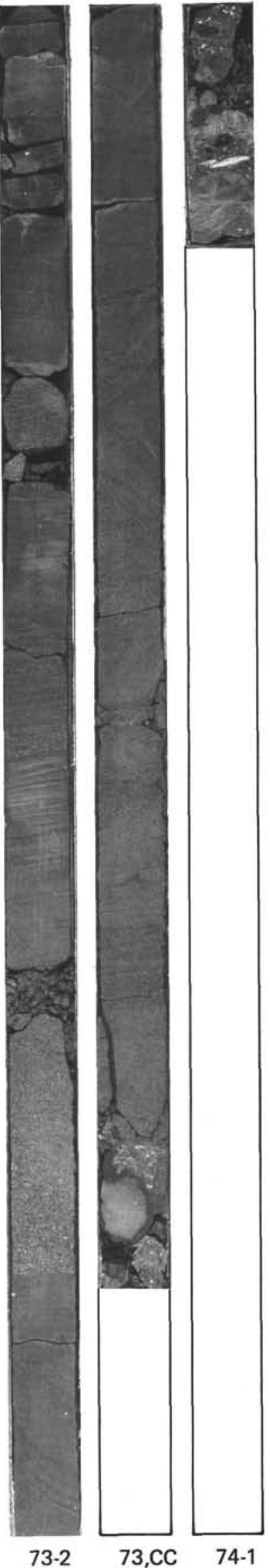


Site 445

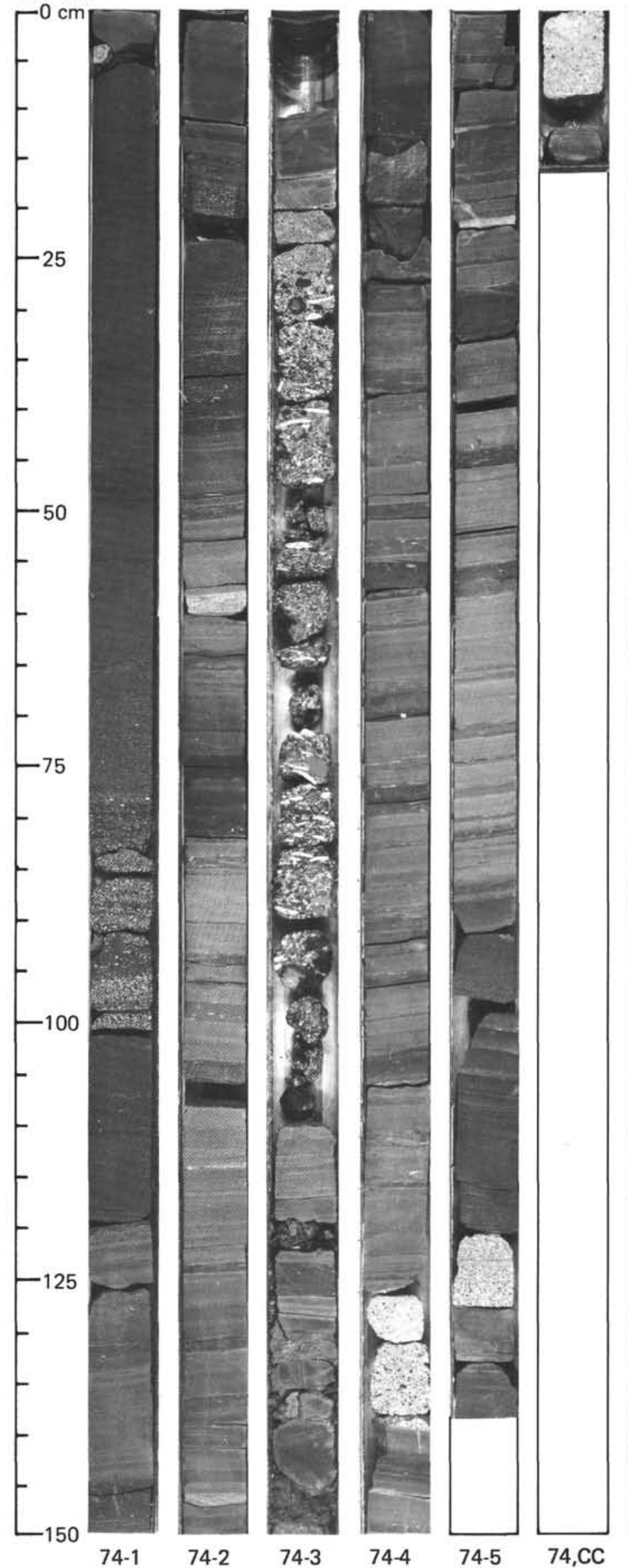

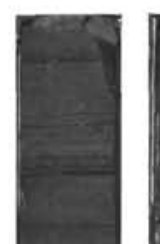
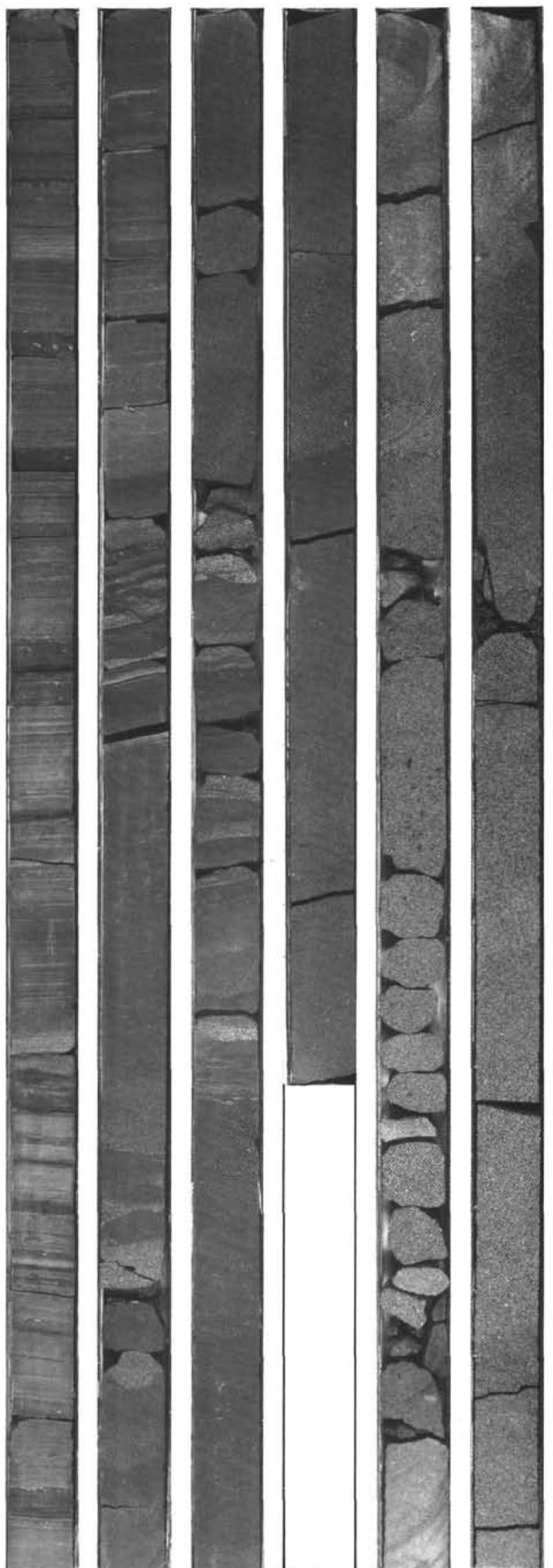

75-1

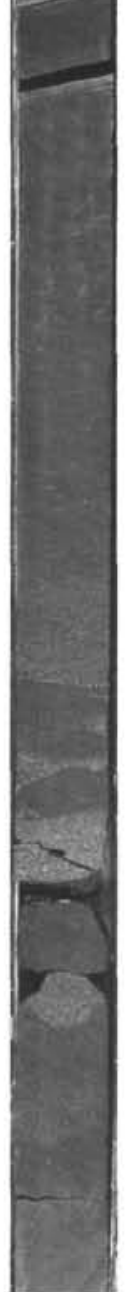

75-2
75-3

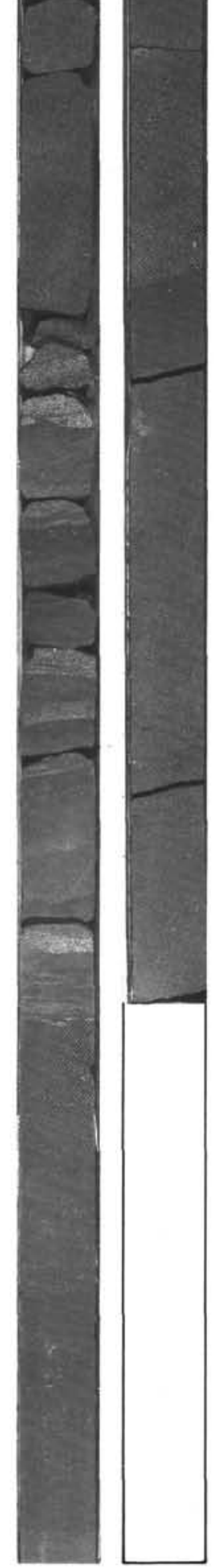


Site 445

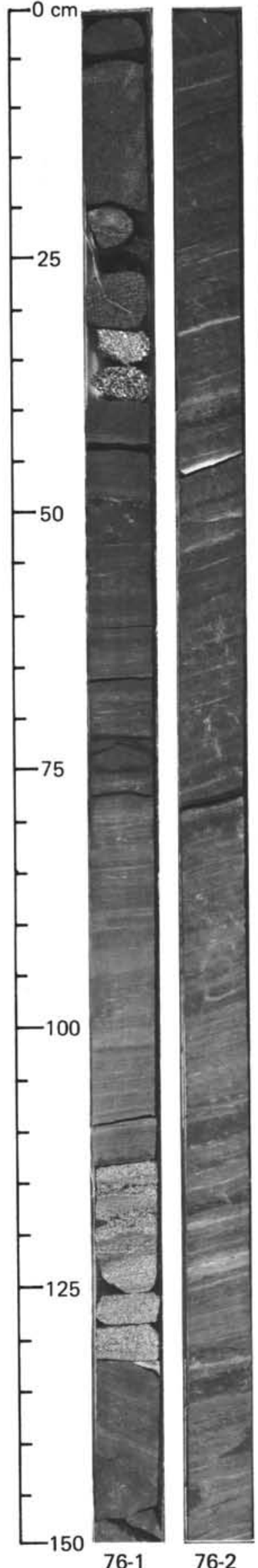

76-1

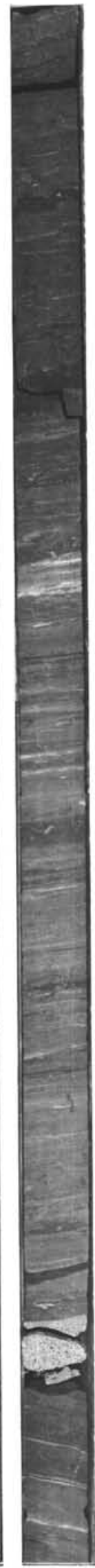

76-3

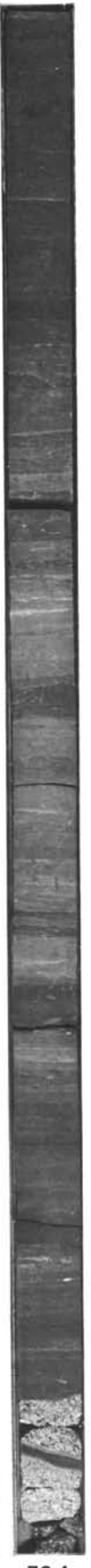

76-4

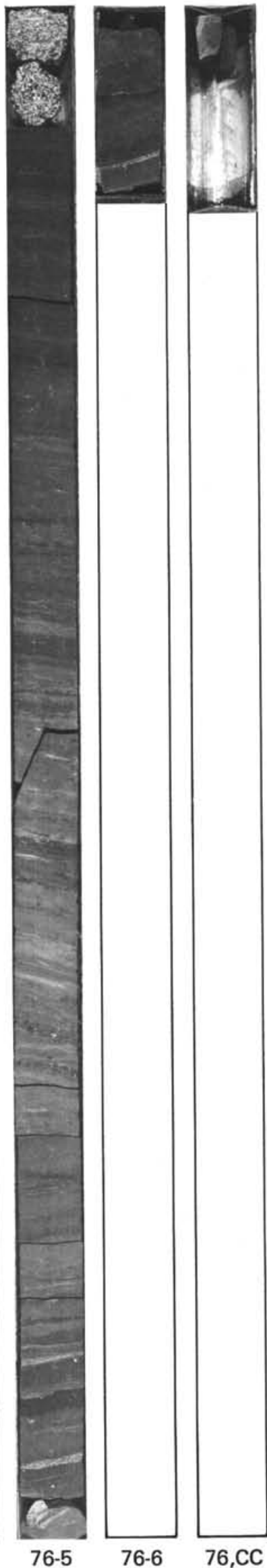

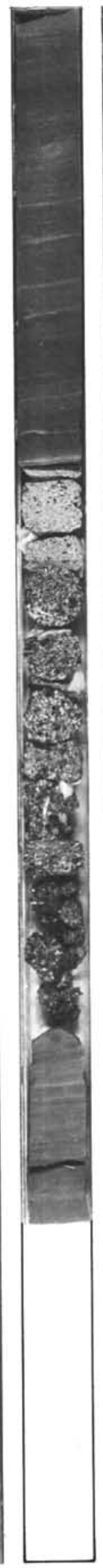

77-2

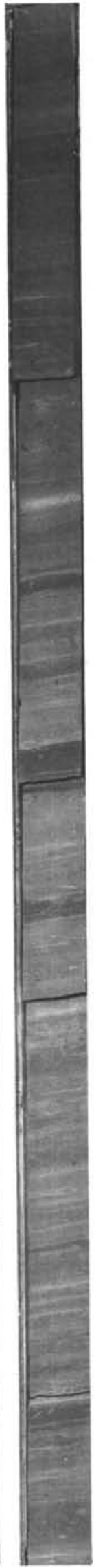

77-3
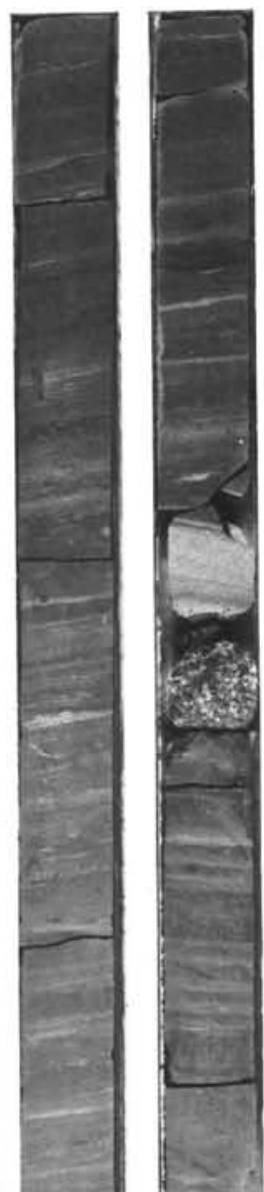

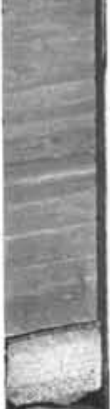
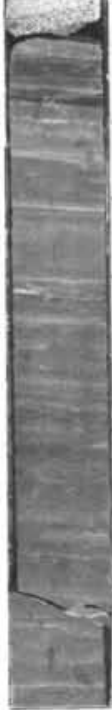

77-4

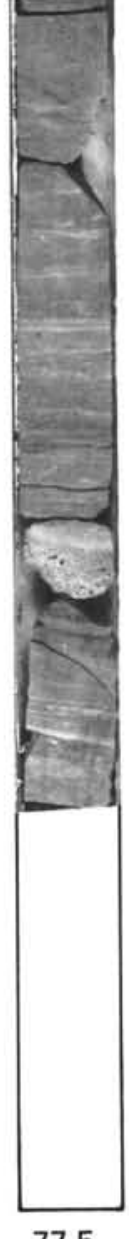


Site 445

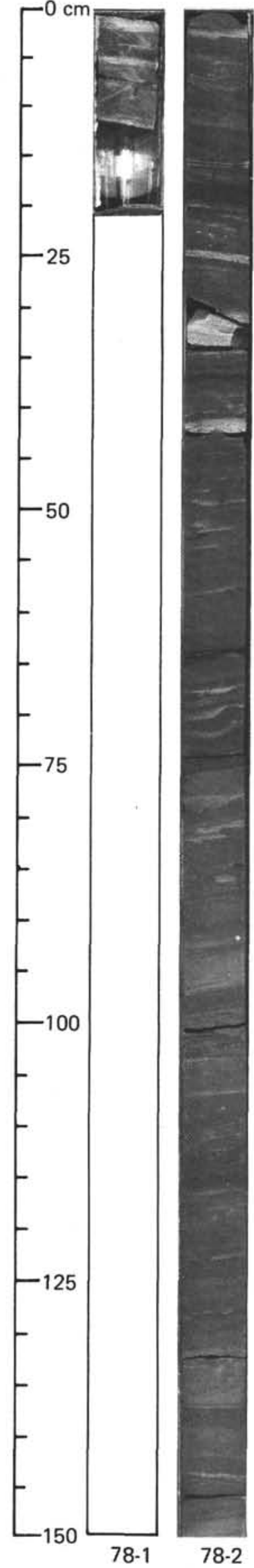

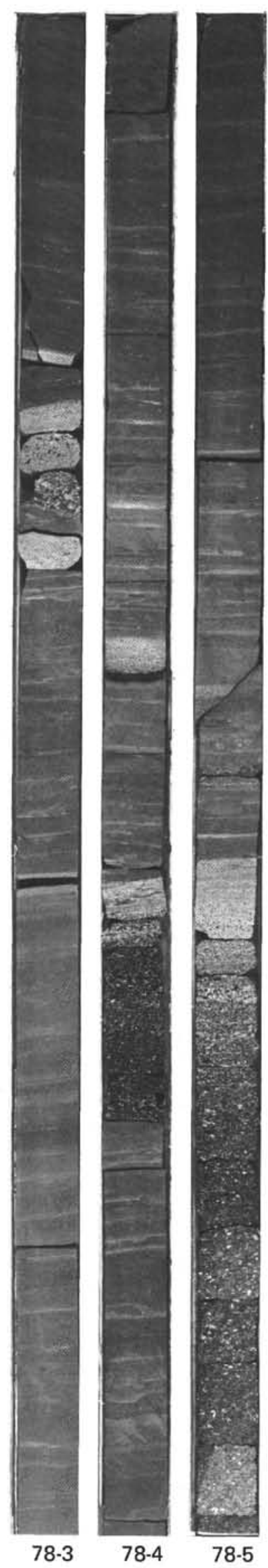

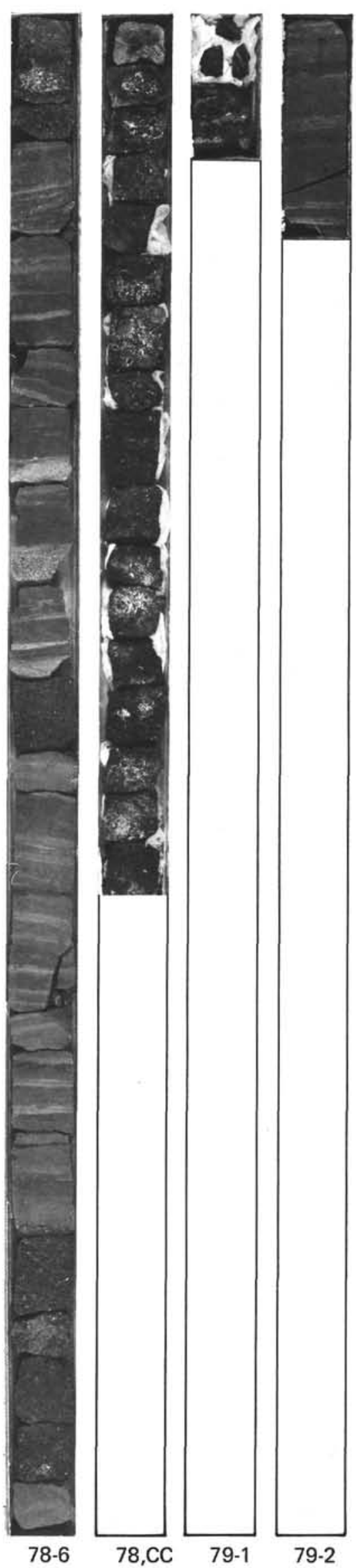

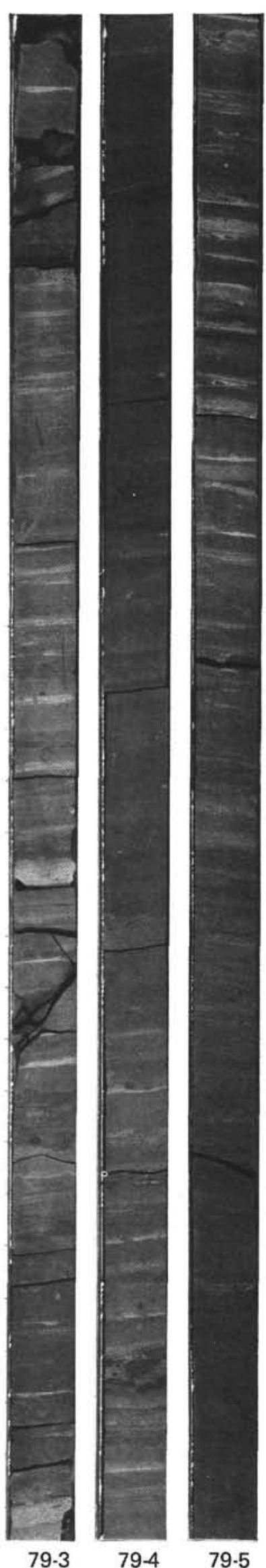


Site 445
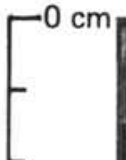

$-25$
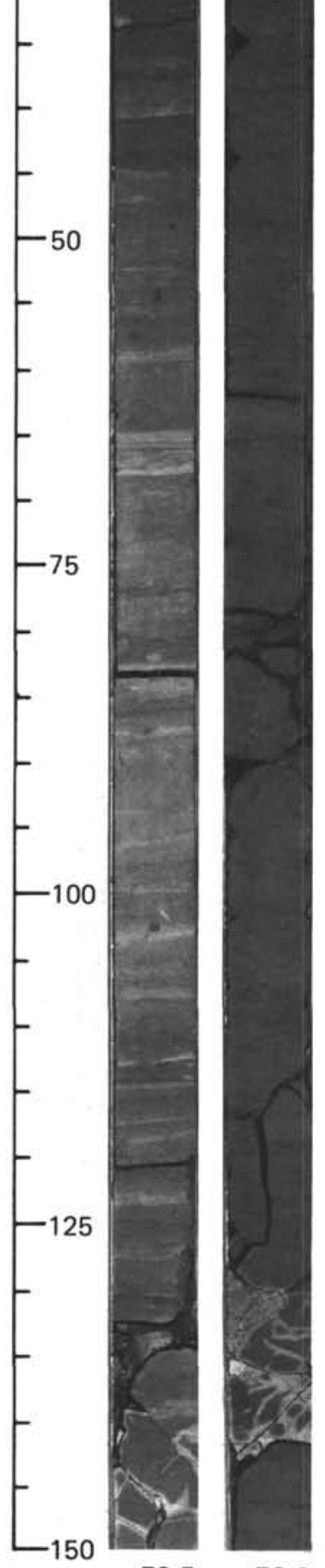

79-5

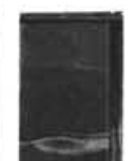

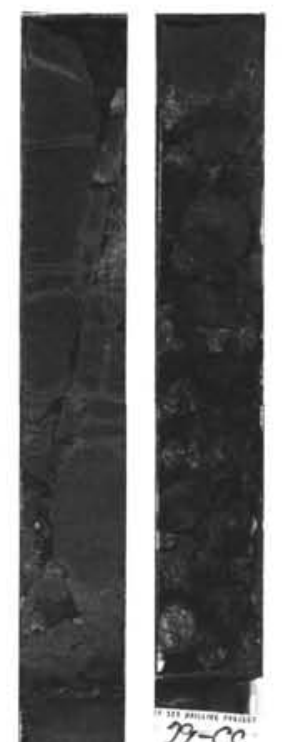

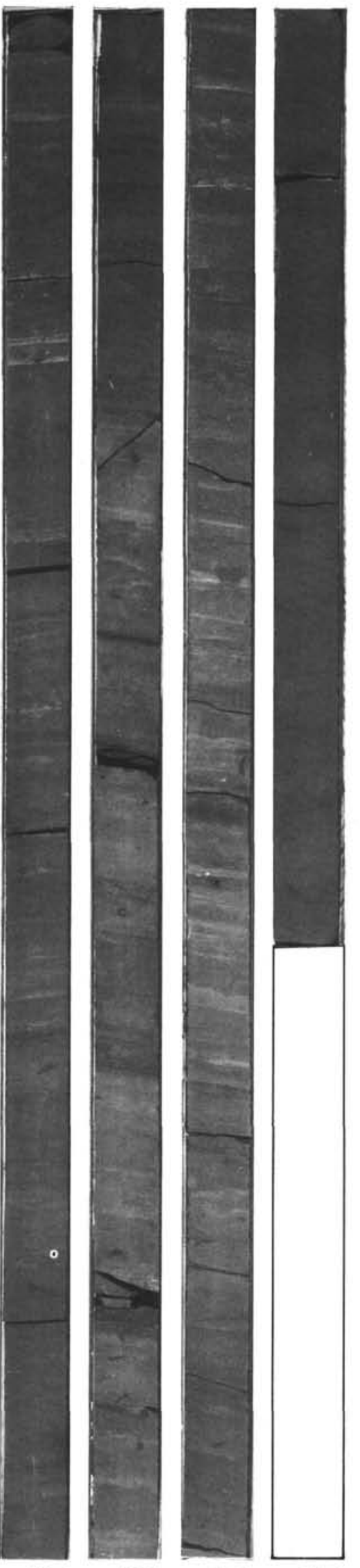

80-1

79-7

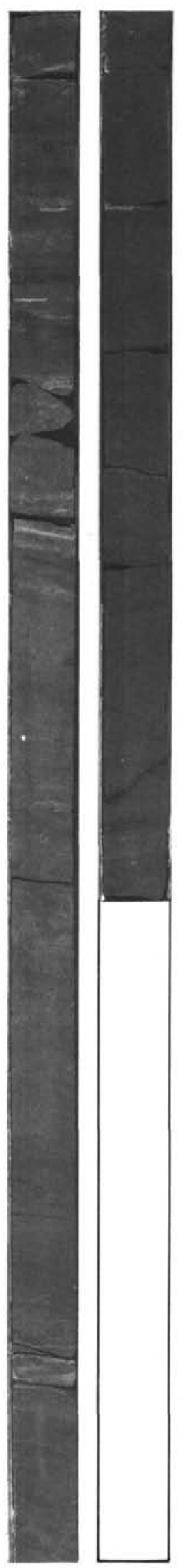

$80-5$

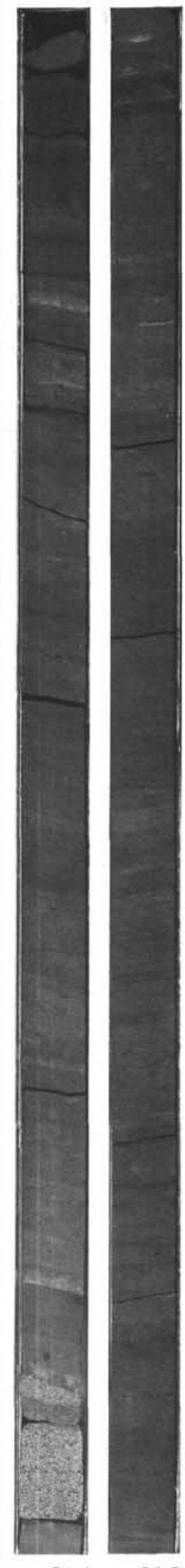

81-1 81-2 


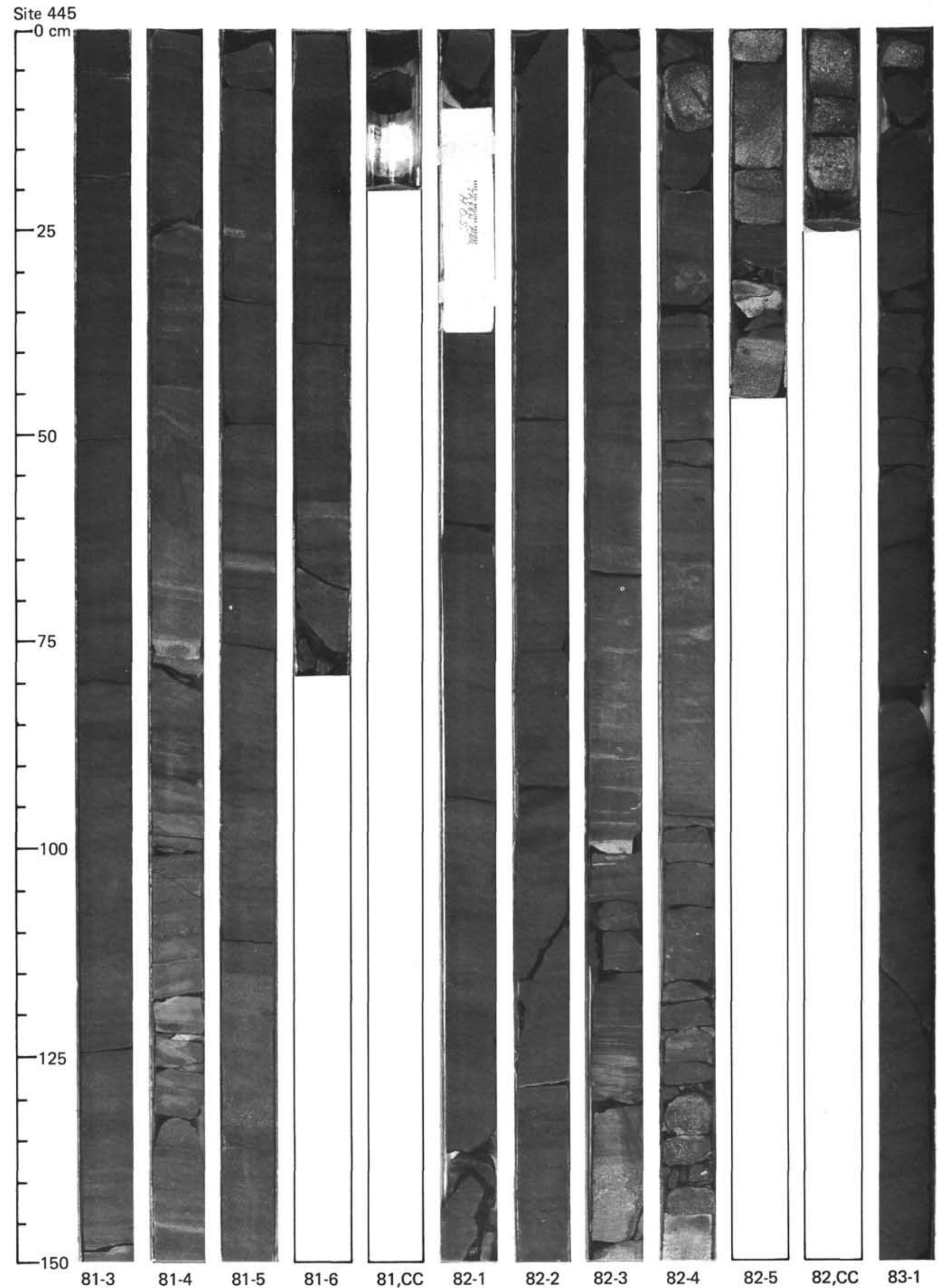


Site 445

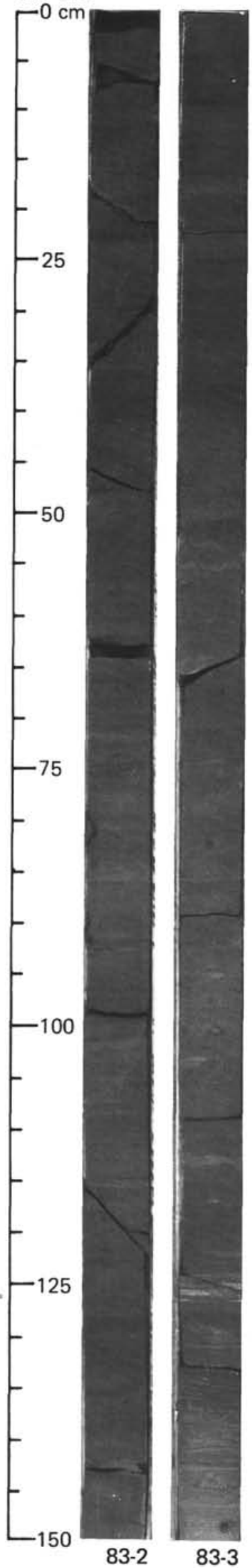

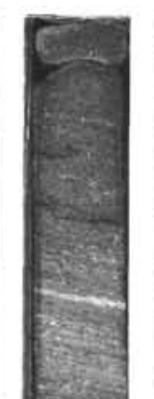
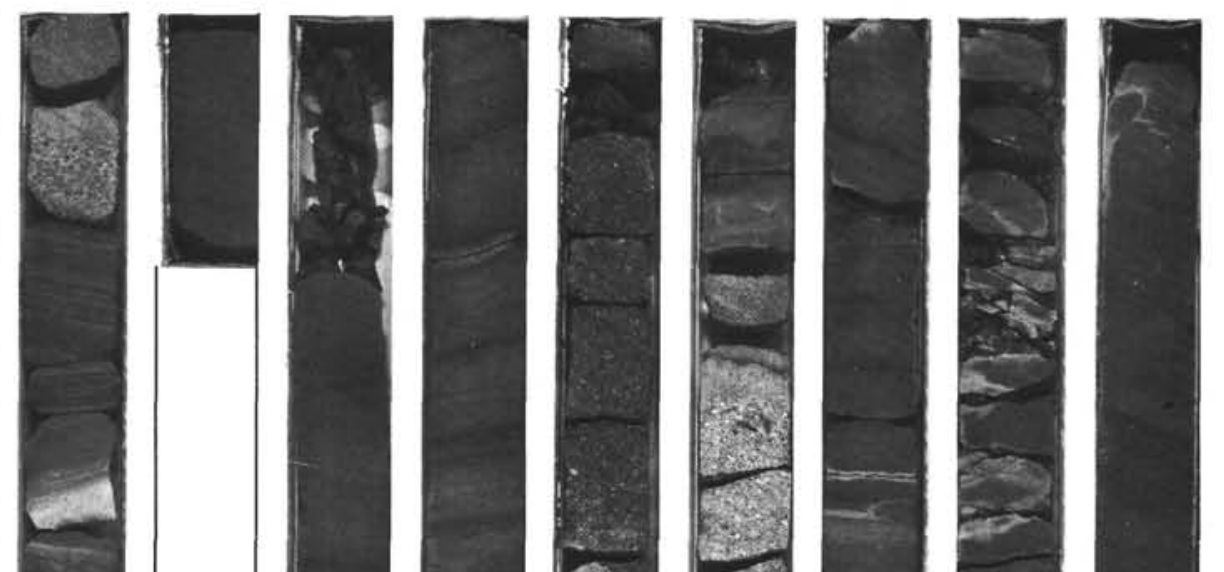

(5)
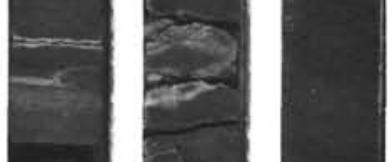

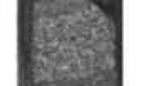

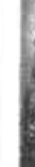

$$
5
$$
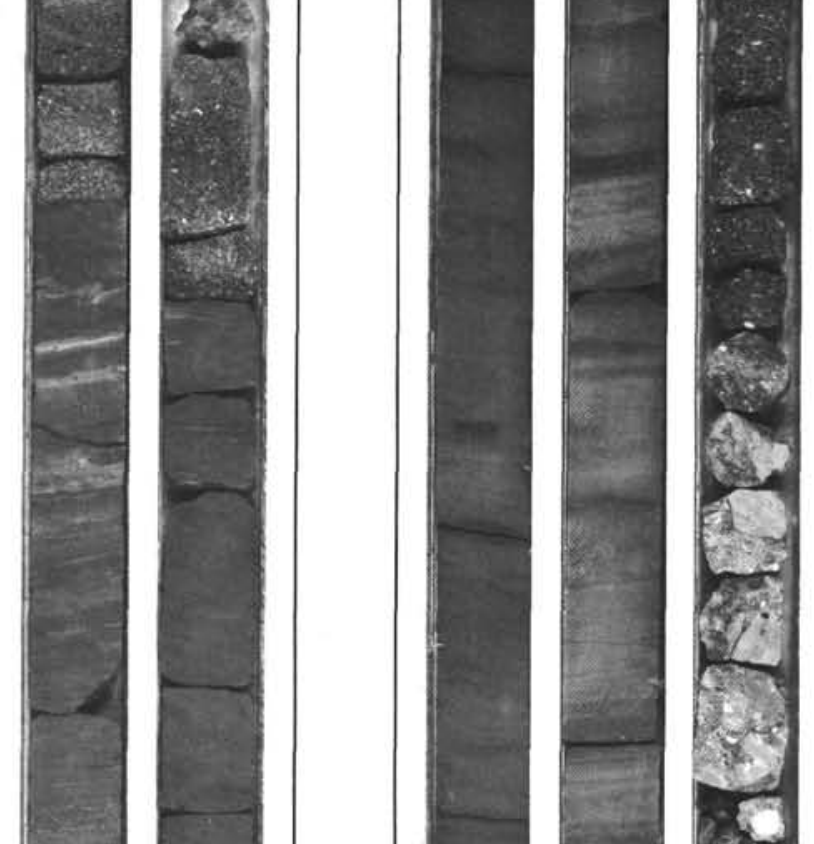

.

곤

6 ist

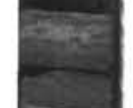

6
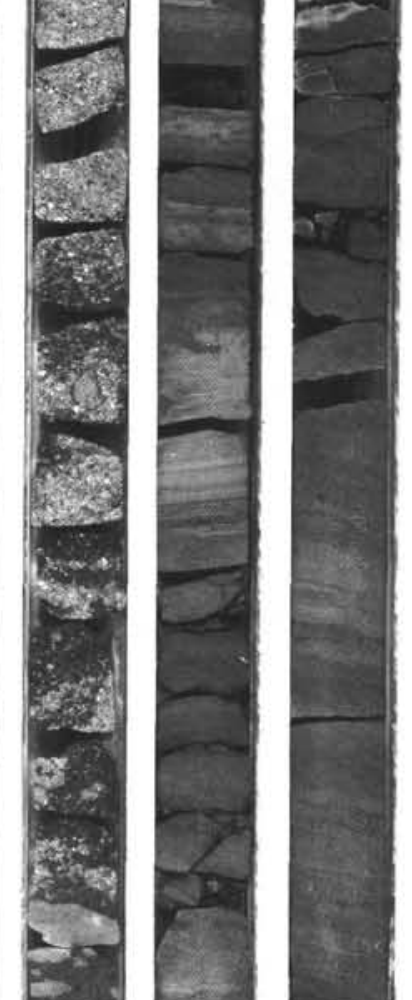

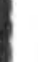 \\ (}
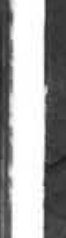


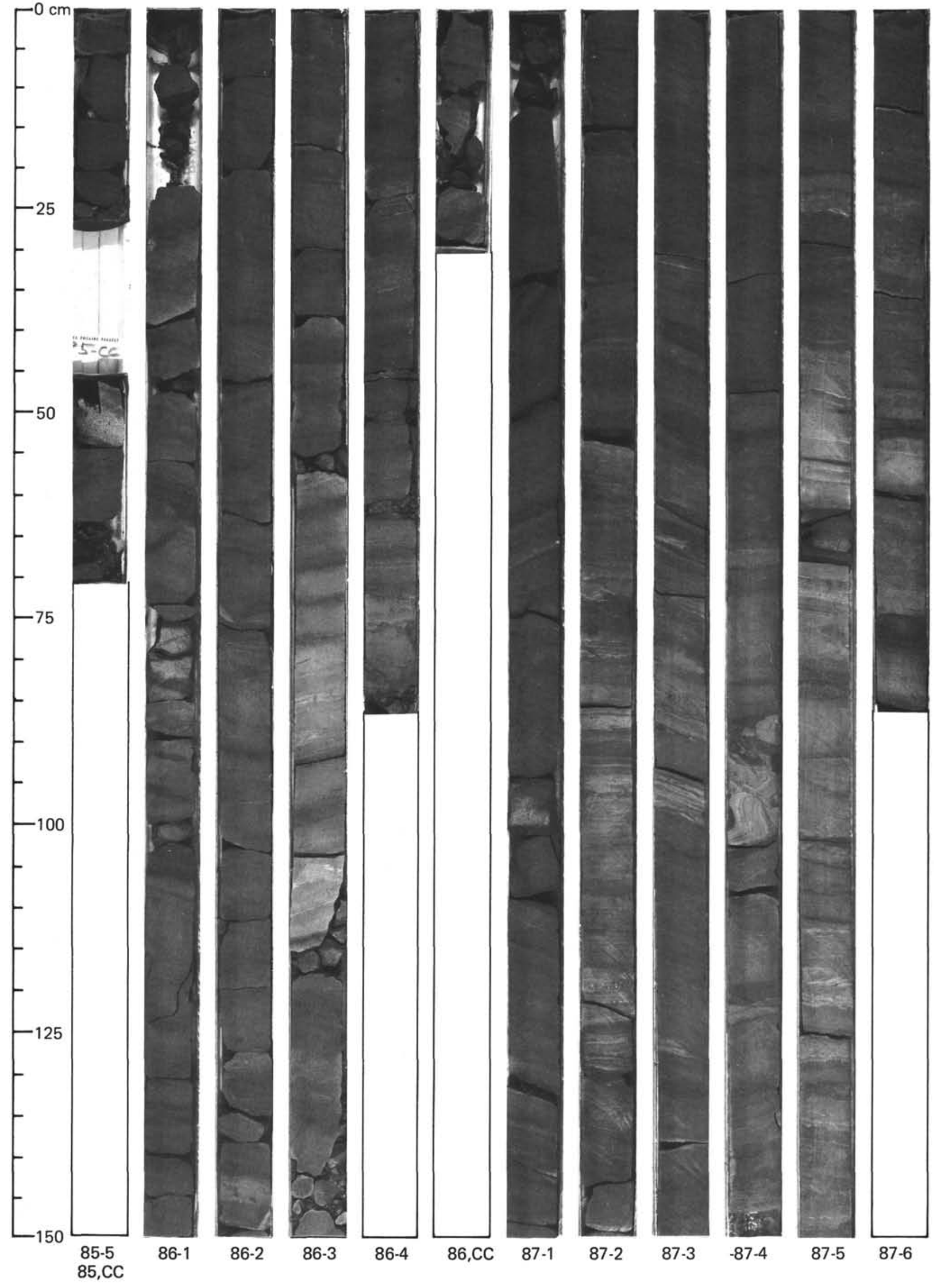




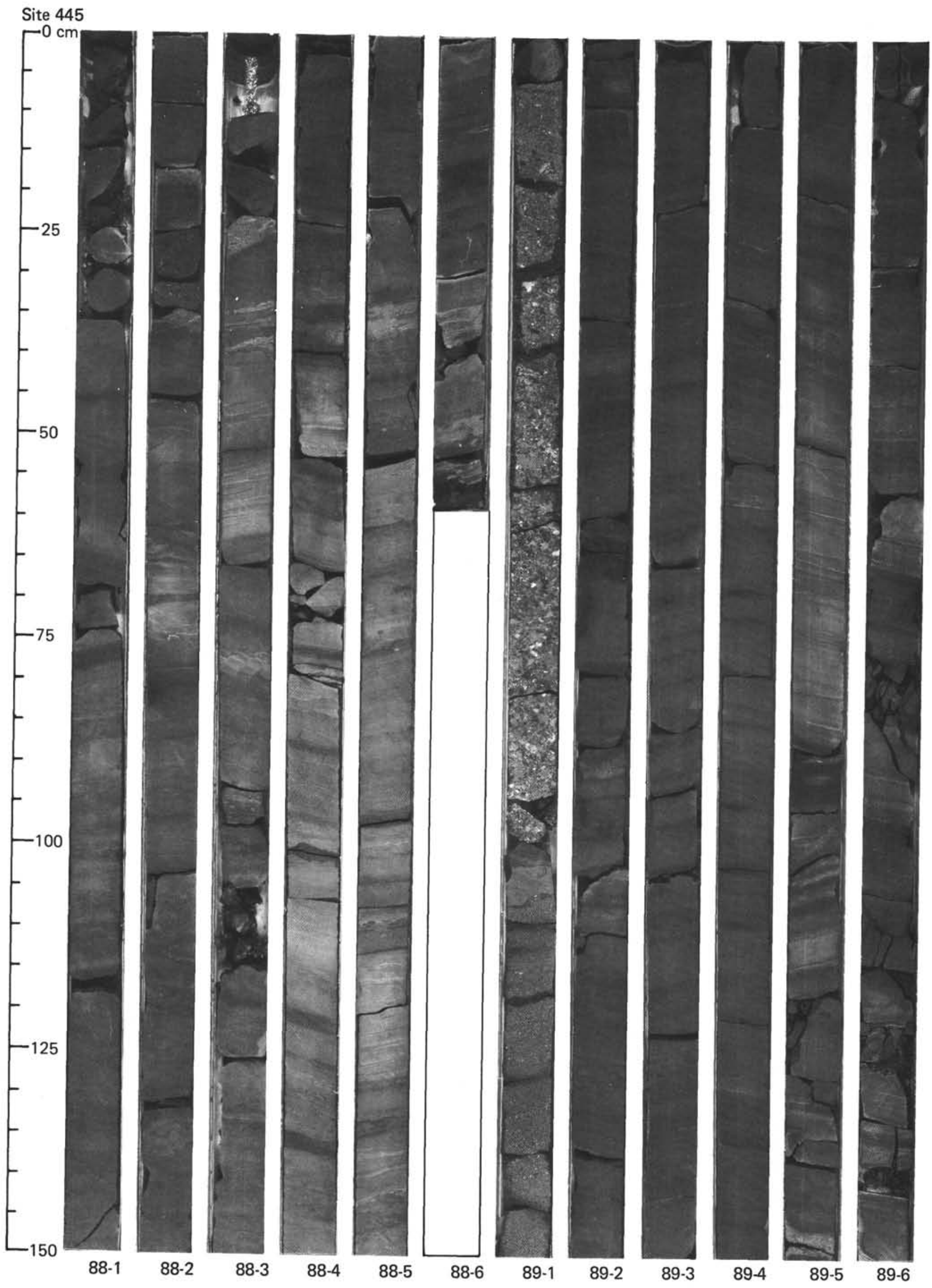


Site 445

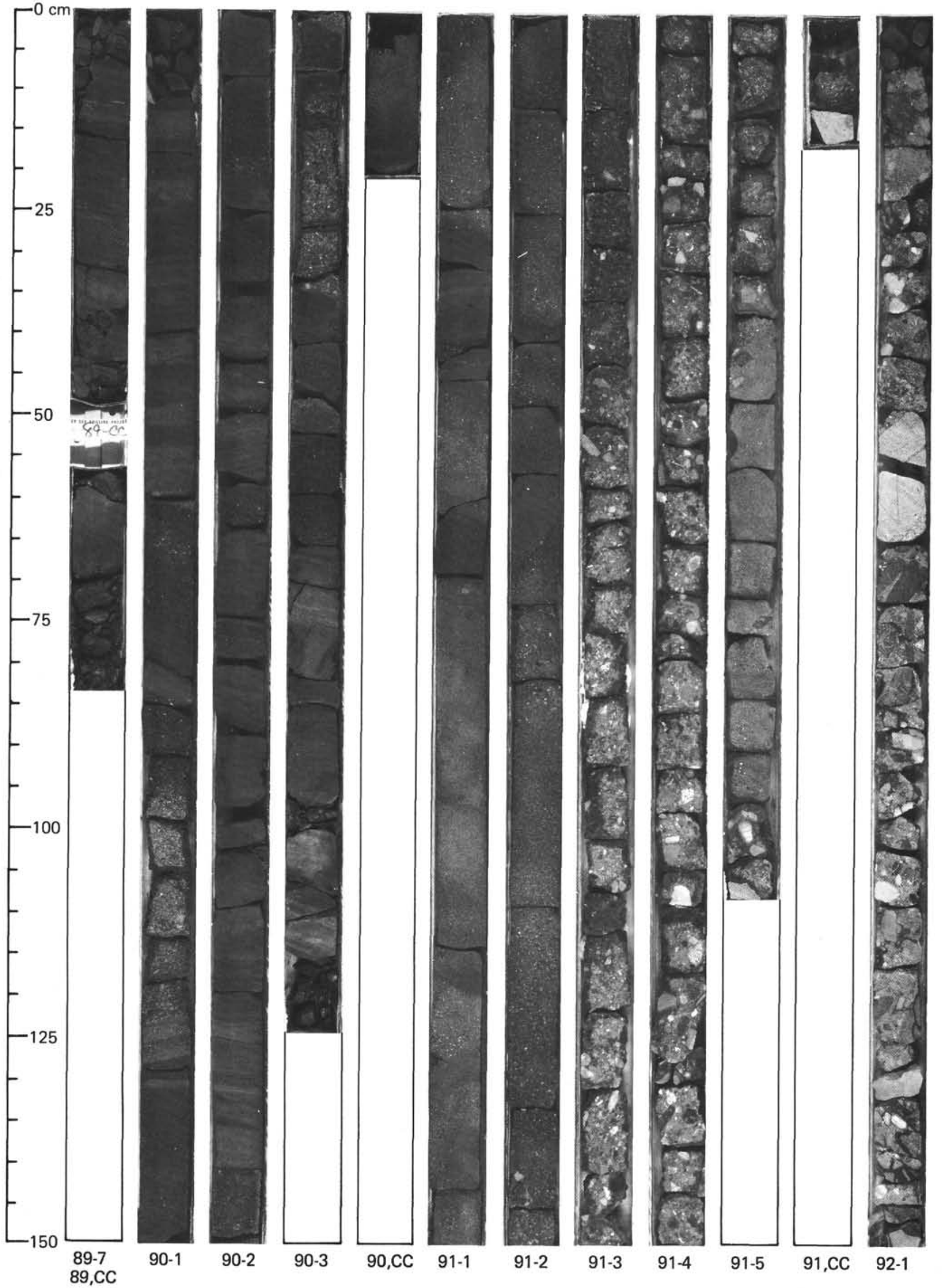


Site 445

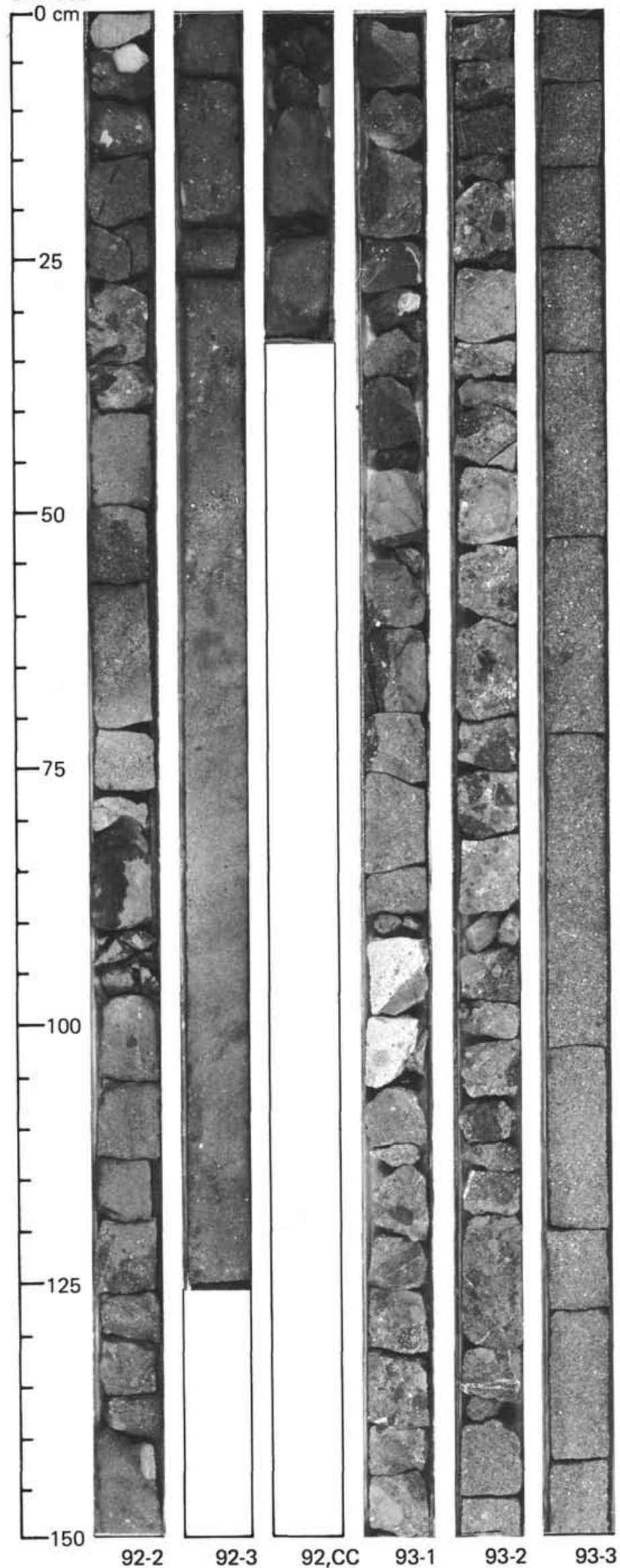

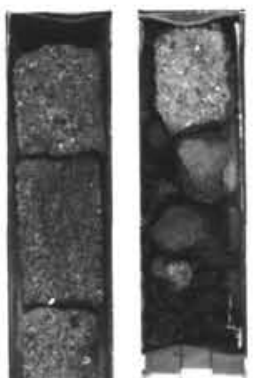
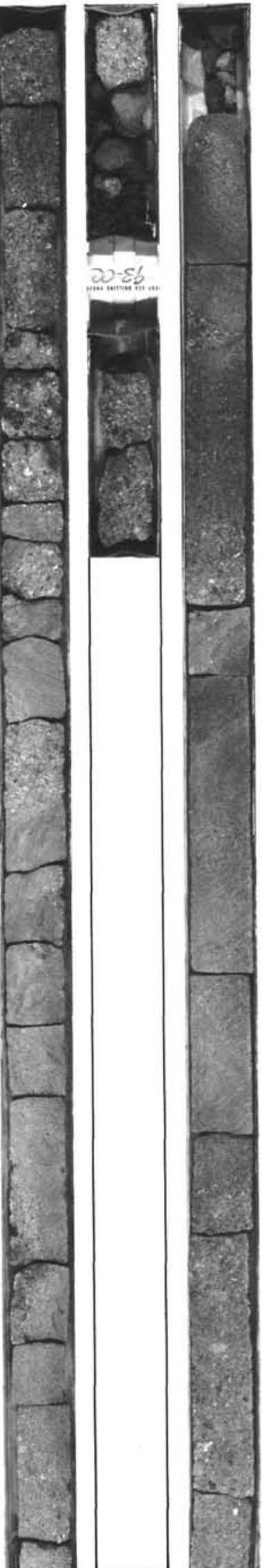

93-4
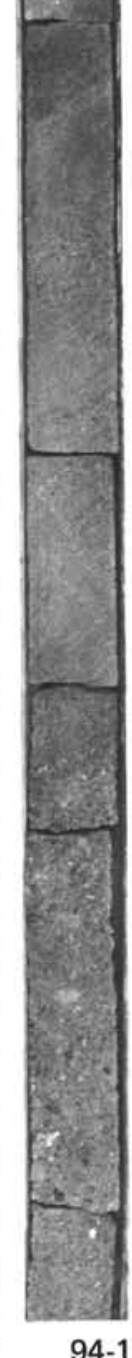
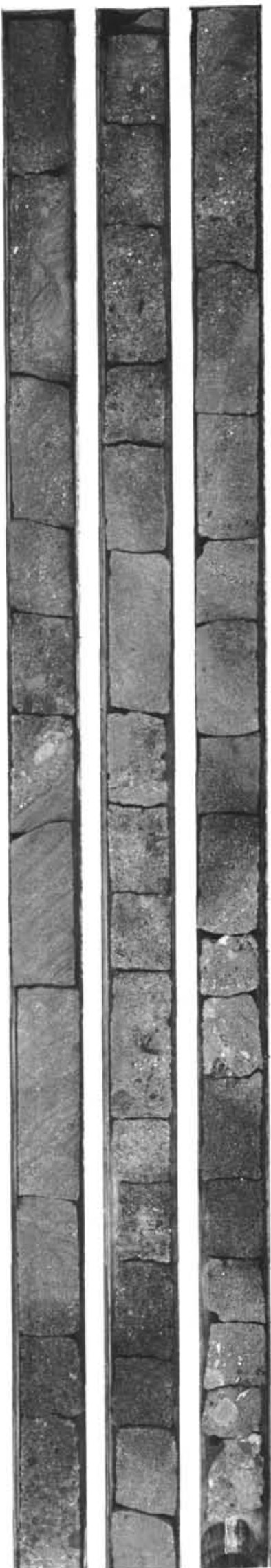

93-5

94-2
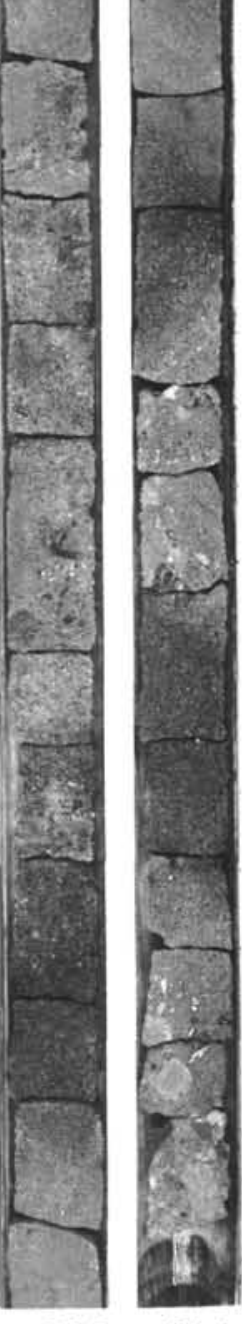

94-3 
SITE 445

Site 445

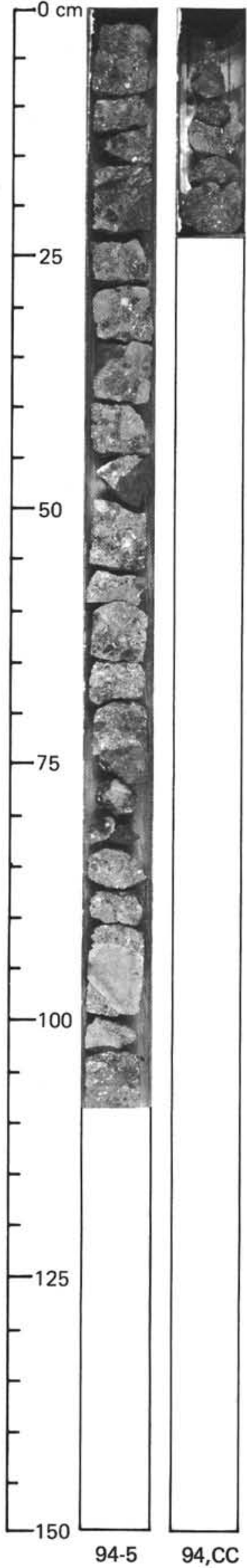

400 